\title{
THE IMPLEMENTATION OF C2005 IN MATHEMATICS AND SCIENCE CLASSES IN MPUMALANGA
}

Colleen Aldous-Mycock 
DOCTORAL COMMITTEE

Chairman: $\quad$ Prof. dr. H.W.A.M. Coonen University of Twente

Promotor: $\quad$ Prof. dr. J. Rogan University of KwaZulu Natal

Promotor: $\quad$ Prof. dr. J.J.H. van den Akker University of Twente

Members: $\quad$ Prof. dr. J.M. Pieters University of Twente

Prof. dr. J.F.M. Letschert University of Twente

Prof. dr. H.M.C. Eijkelhof University of Utrecht

Prof. dr. W.A.J.M. Kuiper University of Utrecht

Dr. W.J.W. Ottevanger Free University of Amsterdam

Aldous-Mycock, Colleen Michelle.

The implementation of C2005 in Mathematics and Science classes in Mpumalanga

Thesis University of Twente, Enschede.

ISBN 978-90-365-2759-0

DOI http://dx.doi.org/10.3990/1.9789036527590

Layout: Sandra Schele

Press: PrintPartners Ipskamp - Enschede

(C) Copyright, 2008, Colleen Michelle Aldous-Mycock

All rights reserved. No part of this book may be produced in any form: by print, photocopy, microfilm, or any other means without written permission from the author. 


\title{
THE IMPLEMENTATION OF C2005 IN MATHEMATICS AND SCIENCE CLASSES IN MPUMALANGA
}

\section{DISSERTATION}

\author{
to obtain \\ the degree of doctor at the University of Twente \\ on the authority of the rector magnificus \\ prof. dr. H. Brinksma
} on account of the decision of the graduation committee to be publicly defended on Friday the $9^{\text {th }}$ of January 2009 at 16.45

by

Colleen Michelle Aldous-Mycock

born on the $16^{\text {th }}$ of January 1963

in Pretoria, South Africa 
Promotors:

Prof. dr. J. Rogan

Prof. dr. J.J.H. van den Akker 


\section{ACKNOWLEDGEMENTS}

This thesis is a result of research carried out by many parties during the time the MSSI was underway in Mpumalanga, South Africa. Countless people participated in the research and several offered support. If I were to mention them by name the list would be several pages long. However, I would like to mention some of the groups of participants as well as some individuals who made a special impact on the study.

- JICA for funding such an ambitious project and giving South Africans the opportunity to learn from our Japanese colleagues.

- The learners, the teachers, the principals and the researchers who took part in the case studies.

- The research team who developed the survey questionnaire over the years.

- The CIs who administered the questionnaires.

- Goeffrey Matsepe who transcribed all the data on the questionnaires and the data capturers who put the data into electronic format.

- Various statistics experts who advised me throughout the study.

- Sandra Schele for all the arrangements she has made for me in the Netherlands whenever I was there to work as well as for the type-setting of this document.

- All my other 'colleagues' at the Department of Curriculum Studies at the University of Twente who have gone out of their way to make each and every visit to the Netherlands a wonderful experience.

- My colleagues in South Africa who allowed me the time to complete this piece of work, particularly Emil Kormuth who was my line manager throughout most of the time I was writing up this thesis.

- Jan van den Akker, one of my supervisors, for giving me the opportunity to study in the Netherlands. It has been an experience that I will value forever. 
- John Rogan, my second supervisor, who has been there as my mentor from the time I left school teaching with a BSc. and a teaching Diploma almost a decade ago. He has given freely of his expertise, support and encouragement unfailingly for all these years. I have learnt so much from you John, not only in our academic area, but also about being a better person.

- My parents, Clifford and Michelle Thackwray, my brother, Kinton Thackwray, my boys Arn and Jac Aldous and my husband, Barry Mycock - all of whom have been supportive throughout all my studies and have made sacrifices for me to be able to move ahead academically. I will always be grateful.

Two CIs who were valued participants in both the case studies and the survey are no longer with us. Chacko Chacko and Riana Venter: You are remembered. 


\section{TABLE OF CONTENTS}

ACKNOWLEDGEMENTS

LIST OF FIGURES AND TABLES vii

1 INTRODUCTION

1.1 The purpose and significance of the study 1

1.2 Context: The Mpumalanga Secondary Science Initiative (MSSI) 3

1.3 The research focus 8

1.4 Structure of the dissertation 9

2. THE CONTEXT OF CURRICULUM CHANGE IN SOUTH AFRICA 11

2.1 International curriculum change in science education 11

2.1.1 The first wave 12

$\begin{array}{ll}\text { 2.1.2 The second wave } & 13\end{array}$

$\begin{array}{ll}\text { 2.2 Curriculum change in sub-Saharan Africa } & 14\end{array}$

2.3 C2005 and political change in South Africa 17

2.4 Deconstructing curriculum implementation 24

2.4.1 Some frameworks for curriculum change 25

2.4.2 Relationships between variables in models or frameworks 32

2.5 Designing new frameworks 35

3. THE CONCEPTUAL FRAMEWORK OF THE STUDY 37

3.1 The Rogan-Grayson framework 37

3.2 The profile of implementation 39

3.3 Capacity to innovate 44

3.4 Outside influences 48

3.5 How the constructs were used to frame the study 52 
4. RESEARCH METHODS 55

4.1 The teacher questionnaire 55

4.1.1 Development of the questionnaire 55

4.1.2 Validity and reliability of the questionnaire 59

4.1.3 Gathering the data 60

4.1.4 Analysis of the data 61

4.2 The case studies 61

4.2.1 The case study approach in Mpumalanga 62

4.2.2 Development of the case study materials 63

4.2.3 Gathering the data 63

4.2.4 Analysing the data 65

4.3 Summary 65

5. DESCRIPTION OF THE SAMPLES FOR THE QUESTIONNAIRE STUDY AND THE CASE STUDIES $\quad 67$

5.1 Description of the teacher sample in the questionnaire study 67

5.2 Description of the schools observed during the case studies 70

$\begin{array}{lll}\text { 5.2.1 Rural schools } & 70\end{array}$

$\begin{array}{ll}\text { 5.2.2 School on private property } & 73\end{array}$

$\begin{array}{lll}5.2 .3 & \text { Township schools } & 73\end{array}$

5.2.4 Ex-model C school $\quad 75$

$\begin{array}{lll}5.3 \text { Summary } & 77\end{array}$

6. MEASURES OF THE THREE CONSTRUCTS 79

6.1 Data on profile of implementation 79

6.1.1 Classroom interaction $\quad 80$

6.1.2 Assessment practice 83

6.1.3 Science and mathematics in society 85

6.1.4 Science practical work 87

6.2 Data on capacity of schools to innovate 88

6.2.1 Teacher factors $\quad 89$

6.2.2 School ecology and management 90

$\begin{array}{lll}\text { 6.2.3 Physical resources } & 91\end{array}$

6.2.4 Learner factors 94 
6.3 Data on outside influences 96

6.3.1 Change forces 96

6.3.2 Professional development 97

6.3.3 Monitoring and accountability 99

$\begin{array}{lll}6.4 & \text { Summary } & 100\end{array}$

7. INTER-RELATIONSHIPS BETWEEN THE CONSTRUCTS AND THE $\begin{array}{ll}\text { SUB-CONSTRUCTS } & 101\end{array}$

$\begin{array}{lll}7.1 & \text { Correlations } & 101\end{array}$

7.1.1 Creation of composite scores for the sub-constructs of the Profile of Implementation 102

7.1.2 Relationships between variables of the sub-constructs of Capacity to Innovate and the composite scores of the sub-constructs of the Profile of Implementation

7.1.3 Relationships between variables of the sub-constructs of Outside Influences and the composite scores of the subconstructs of the Profile of Implementation 110

$\begin{array}{lll}7.2 & \text { Stepwise regressions } & 113\end{array}$

7.2.1 Predicting Classroom Interaction 114

$\begin{array}{lll}\text { 7.2.2 Predicting assessment } & 115\end{array}$

7.2.3 Predicting the teaching of Science and Mathematics in $\begin{array}{ll}\text { Society } & 117\end{array}$

7.2.4 Predicting Science Practical Work 118

$\begin{array}{lll}7.3 & \text { Summary } & 119\end{array}$

7.3.1 Capacity to Innovate relationships 119

$\begin{array}{ll}\text { 7.3.2 Outside Influences } & 120\end{array}$

$\begin{array}{ll}\text { 8. DISCUSSION } & 123\end{array}$

8.1 Recapitulation of the research problem and approach 123

$\begin{array}{ll}8.2 & \text { Summary of the main findings } \\ & 125\end{array}$

8.2.1 Profile of Implementation 125

$\begin{array}{ll}8.2 .2 & \text { Capacity to Innovate } \\ 8.2 .3 & 128\end{array}$

$\begin{array}{ll}\text { 8.2.3 Outside Influences } & 130\end{array}$

8.2.4 Influential variables on implementation 130 
$\begin{array}{ll}\text { 8.3 Discussion of the findings } & 131\end{array}$

$\begin{array}{lll}\text { 8.3.1 School Community } & 131\end{array}$

$\begin{array}{ll}\text { 8.3.2 Socio-economic Circumstances } & 138\end{array}$

\begin{tabular}{ll}
8.4 & Reflections on research approach \\
\hline
\end{tabular}

$\begin{array}{lll}8.5 & \text { Recommendations } & 140\end{array}$

$\begin{array}{lll}\text { 8.5.1 Leadership } & 140\end{array}$

$\begin{array}{lll}\text { 8.5.2 Teachers } & 141\end{array}$

8.5.3 Resources 141

8.5.4 A differentiated approach to implementation 142

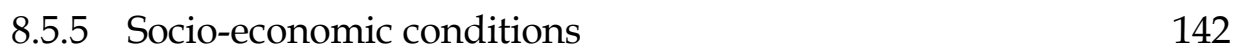

$\begin{array}{lll}8.6 & \text { Conclusion } & 143\end{array}$

$\begin{array}{ll}\text { ENGLISH SUMMARY } & 145\end{array}$

$\begin{array}{ll}\text { REFERENCES } & 151\end{array}$

$\begin{array}{lr}\text { APPENDICES } & 159\end{array}$ 


\section{LIST OF FIGURES AND TABLES}

\section{FIGURES}

1.1 The Cascade Model used to convey new experience and materials from the level of MSSI coordinators to the learners 6

2.1 Zucker et al.'s model of Systemic Reform used to Guide SRI studies 28

2.2 Hopkins' model for school improvement 30

3.1 The constructs and sub-constructs of the Rogan-Grayson framework 38

\section{TABLES}

1.1 Grade 12 pass rates for mathematics and science in percentages

1.2 Some MSSI Statistics

3.1 Profile of Implementation contextualised for the Natural Science Learning Area of South Africa's Curriculum 2005

3.2 Levels of factors that form the capacity to support innovation within a school

3.3 Levels of outside influences

4.1 Alignment between items in the 2003 questionnaire and sub-constructs from the Rogan and Grayson framework

4.2 Number of schools and teachers that participated in the questionnaire study

5.1 Science and mathematics teachers in Grades 8 and 9

$\begin{array}{lll}5.2 & \text { Age of teachers in age groups } & 68\end{array}$

5.3 Gender of teachers for mathematics and natural science 68

5.4 Percentages of teachers with various categories of years of experience for subjects related to natural science and mathematics teaching

5.5 Percentage of teachers teaching mathematics, natural science, physical science and biology in different grades

6.1 Frequency percentages of classroom interaction practices, indicating level of implementation

6.2 Frequency percentages of assessment practices

6.3 Frequency percentages of use of ways of including science and mathematics in societal issues 
6.4 Frequency percentages of types of practical work carried out 87

6.5 Frequency percentages of teachers' perceptions 89

66. Frequency percentages and means of school ethos and management 91

6.7 Resources available at the schools 92

6.8 Effect of a resource on implementation in percentages 92

6.9 Provision of learner resources in percentages 93

6.10 Access learners have to textbooks 94

6.11 Frequencies and means of learner factors 95

6.12 Frequencies of factors influencing willingness to implement C2005 97

6.13 Teacher attendance of workshop since January $2001 \quad 98$

6.14 Effect of workshop on implementation of C2005 98

6.15 Persons who might monitor the school's compliance with curriculum implementation $\quad 99$

7.1 Correlation of Profile of Implementation composites correlated with variables of teacher factors

104

7.2 Correlation of Profile of Implementation composites correlated with variables of learner factors 106

7.3 Correlation of Profile of Implementation composites correlated with $\begin{array}{ll}\text { variables of physical resources } & 107\end{array}$

7.4 Correlation of Profile of Implementation composites correlated with variables of Ecology and management 109

7.5 Correlation of Profile of Implementation composites correlated with variables of Outside Influences

7.6 Stepwise Multiple Regression model for Capacity to Innovate factors that predict Classroom Interaction

7.7 Stepwise Multiple Regression model for Outside Influences factors that predict Classroom Interaction

7.8 Stepwise Multiple Regression model for Capacity to Innovate factors that predict Assessment practice

7.9 Stepwise Multiple Regression model for Outside Influences factors that predict Assessment practice

7.10 Stepwise Multiple Regression model for Capacity to Innovate factors that predict the teaching of Science and Mathematics in Society

7.11 Stepwise Multiple Regression model for Outside Influences factors that predict the teaching of Science and Mathematics in Society

7.12 Stepwise Multiple Regression model for Capacity to Innovate factors that predict the teaching of Science Practical work 


\section{CHAPTER 1 \\ Introduction}

The central aim of this dissertation is to investigate how several school-based factors and outside influences relating to general science and mathematics curriculum change in South Africa have impacted on the implementation process of Curriculum 2005 (C2005) in Mpumalanga. Rogan and Grayson (2003) defined the factors that are investigated in a model that will be constantly referred to in this dissertation. The changes in the general science and mathematics curriculum have taken place within the overall curriculum change undertaken in South Africa since 1994, i.e. the development and introduction of C2005.

In this first chapter, some of the background to the curriculum changes that occurred in South Africa since 1994 is given to provide a context for the research (1.1). The greater project in which this study was placed, the Mpumalanga Secondary Science Initiative (MSSI), is described below (1.2) after which the research questions are posed (1.3). The structure of the dissertation is explained at the end of the chapter (1.4).

\subsection{THE PURPOSE AND SIGNIFICANCE OF THE STUDY}

The new Government of National Unity that came into power in 1994 jettisoned apartheid education and introduced an entirely new curriculum. Education was no longer portioned into unique curricula for various race groups. There was now a single curriculum for all South Africans regardless of race, which had as a major thrust, the introduction of outcomes-based education (OBE). The first efforts at curriculum change after the 1994 elections were met with optimism because of the intended abolishing of a racially defined education, but they also attracted wide criticism. By the turn of the century, research tracking the effects of curriculum change indicated that the distance between privileged schools and disadvantaged schools had increased rather than decreased. Jansen (1999) put this down to two main reasons: 
1. Teachers were retrenched after 1994 and offers of attractive financial packages to leave teaching meant that many teachers left from all schools across the spectrum. The result was that black schools became depleted of teachers leading to enormous class sizes, but the privileged schools were able to reemploy teachers by paying them salaries from increased school funds, thus maintaining the old learner/teacher ratio.

2. Outcomes-based education, being resource hungry, meant that well resourced schools were able to implement C2005, while black schools fell further behind because of their lack of resources and their low capacity for managing complex innovations. It should be explained at this point that although all schooling was no longer subjected to racial policy, well-off former white schools became racially integrated while the poorly resourced former black schools did not.

The negative criticism resulted in a major review of the new curriculum. However, neither of Jansen's concerns was specifically addressed in the development of the Revised National Curriculum Statement (RNCS), which became policy in 2002. Teacher/learner ratios remained unaltered, the OBE curriculum remained resource hungry and schools were still under-financed. On the whole, academics remained sceptical about OBE throughout the review process that led to the RNCS. They argued that the problems were not with OBE per se, but rather issues connected with it such as teacher education, learning support materials, provincial support and time frames (Chisholm, 2003). It appeared that a high-quality curriculum had been created but with no consideration of the tools required for implementation. There were, and remain, a plethora of questions that can be researched into the disappointing uptake of C2005. It is imperative therefore that much research must be undertaken to analyse and understand the situation as it is and how it got there in South Africa.

Research of this nature might illuminate the path for further change.

It is within this context that this study will pursue an investigation into what factors at the implementation levels should be considered in South Africa in order to improve the implementation process of new curricula, given the diversity of schools and their capacities to implement new curricula. A theoretical framework has been selected that has within it three defined areas that might affect successful curriculum implementation. Each of these areas has a variety of specific impacting factors for consideration. To this end the framework proposed by Rogan and Grayson (2003) will be used to define the scope of the study. It was developed during the course of the MSSI as a possible generic model for developing countries. The model will be explicated in chapter 3 . 


\subsection{ConteXt: The MpUmalanga Secondary ScIENCE InITIATIVE (MSSI)}

The MSSI was a province wide science and mathematics education project carried out in Mpumalanga and was funded by Japan. Mpumalanga is one of the nine South African provinces demarcated after 1994. 'Mpumalanga' means 'where the sun rises' in the vernacular language of the area, a coincidence not overlooked by the Japanese funders of the project whose country shares the name (Japan is referred to as the place of the rising sun).

Japan is one of the world's leading donors of official development assistance (ODA). In 2000, it was the largest ODA contributor as well as the largest contributor of bilateral educational ODA of the Development Assistance Committee (Nagao, 2004). Japan's activity in education in Africa was endorsed by the Japanese Government-supported Second Tokyo International Conference on African Development (TICAD II) in 1998, which declared, "capabilities in science and technology will be raised on the national as well as regional levels (in Africa)" (Ministry of Foreign Affairs, 2001 in Nagao, 2004). Japan's official agency for technical cooperation, The Japan International Cooperation Agency (JICA), has taken up this responsibility by offering assistance in mathematics and science education in Africa since the late 1990's. Assistance projects generally have a three to five year term, with extension possibilities, and usually aim at strengthening the capacity of mathematics and science teachers in primary and secondary schools through teacher retraining programs conducted with the aid of Japanese experts, as well as through training of teacher trainers and related staff in Japan (Nagao, 2004).

Mpumalanga is a rural province without any large cities and with an economy based primarily on agriculture and tourism. African children in rural areas were educationally more disadvantaged than those in urban areas in the apartheid times (Hofmeyer \& Buckland, 1992). This legacy has carried forward into the post apartheid era. As a result, learners in Mpumalanga were still under-performing well into the post-apartheid era. Owing to the poor national performance of its learners in mathematics and science as shown in Table 1 (Ofir, 2002), the Mpumalanga Department of Education (MDE) targeted mathematics and science education as a priority area for performance improvement. 
Table 1.1 Grade 12 pass rates for mathematics and science in percentages

\begin{tabular}{|ccccc} 
& \multicolumn{2}{c}{ National } & \multicolumn{2}{c}{ Mpumalanga } \\
\cline { 2 - 5 } & Mathematics & Science & Mathematics & Science \\
\hline 2000 & 45.1 & 68.7 & 36.5 & 60.2 \\
\hline & 46.7 & 68.6 & 36.0 & 58.0 \\
\hline
\end{tabular}

The Department proposes to achieve this target by retraining its mathematics and science teachers. The retraining was aimed at compensating for deficiencies that may have existed in their instructional capacity because of the training shortfall dating back to apartheid times, and at facilitating the introduction of C2005.

The curriculum implementation project was jointly planned between the Japanese International Co-operation Agency (JICA) and the Mpumalanga Department of Education (MDE). It aimed to establish school-based in-service training (INSET) for teachers throughout the Mpumalanga province in order to enhance their subject knowledge and teaching skills (taking C2005 into account) and in so doing improve the quality of teaching in mathematics and general science.

The MSSI INSET project took its cue from an earlier project called the Mpumalanga Primary Schools Initiative that was aimed at INSET at the Grades 4-6 level. The British government supported this project and JICA then agreed to fund a similar project geared at the secondary level. The Centre for Science Education (CSE) at the University of Pretoria was asked to join the partnership for its expertise in science education and science education research. The CSE, MDE and JICA formed the Coordinating Committee to coordinate and support the curriculum implementation initiative.

The aim of the first phase of the MSSI was to improve Grade 8 and 9 learners' skills in mathematics and science, to stimulate their interest and to encourage participation in these subjects. A second phase was embarked upon in 2004 which included the Further Education and Training levels (Grades 10 -12). In order to achieve this aim, the MSSI worked on the assumption that the implementation of a system of school-based INSET with a focus on improving teaching quality would lead to improved learning and participation. 
The MSSI objectives were (Ofir, 2004):

1. to enhance the teachers' subject knowledge and teaching skills in order to improve the quality of teaching in mathematics and science in the Province;

2. to establish a school-based in-service training system in the Mpumalanga Province.

The MSSI was underpinned by the following approach:

1. to combine the retraining of teachers to improve their capacity with the training needed for the introduction of Curriculum 2005 (C2005) and Outcomes-based Education (OBE);

2. to promote a partnership approach between the three entities involved;

3. to build a province-wide in-service training system with a school-based approach;

4. to provide individual incentives for teachers through accreditation schemes.

The first phase of the MSSI was phased in over three years. In the first year schools were selected from four out of a total of ten districts. Four districts were added in the second year and in the third year the remaining two were added. By the third year of phase I, 313 schools of the 521 in Mpumalanga were participants in the MSSI (Ofir, 2004).

There were three primary target groups viz. the MDE's Curriculum Implementors (CIs) who were responsible for training teachers, the Heads of Departments (HoD's) or Subject Heads (SH's) for mathematics and science in the schools, and the Grade 8 and 9 science and mathematics teachers. Table 2 provides participation statistics.

Table 1.2 Some MSSI Statistics (Ofir, 2004)

\begin{tabular}{|lc} 
Mpumalanga schools offering Grade 8 and 9 mathematics and science & 521 \\
\hline Number of participating schools & 313 \\
\hline Number of Heads of Department/Subject Heads in participating school & Appr. 300 \\
\hline Number of participating CI's & 23
\end{tabular}

The Initiative was to train CIs who, in line with the cascade model, were to train the HoDs/SHs of the participating schools, who were then to train the teachers. The cascade model as utilized by the MSSI is shown in Figure 1.1. 


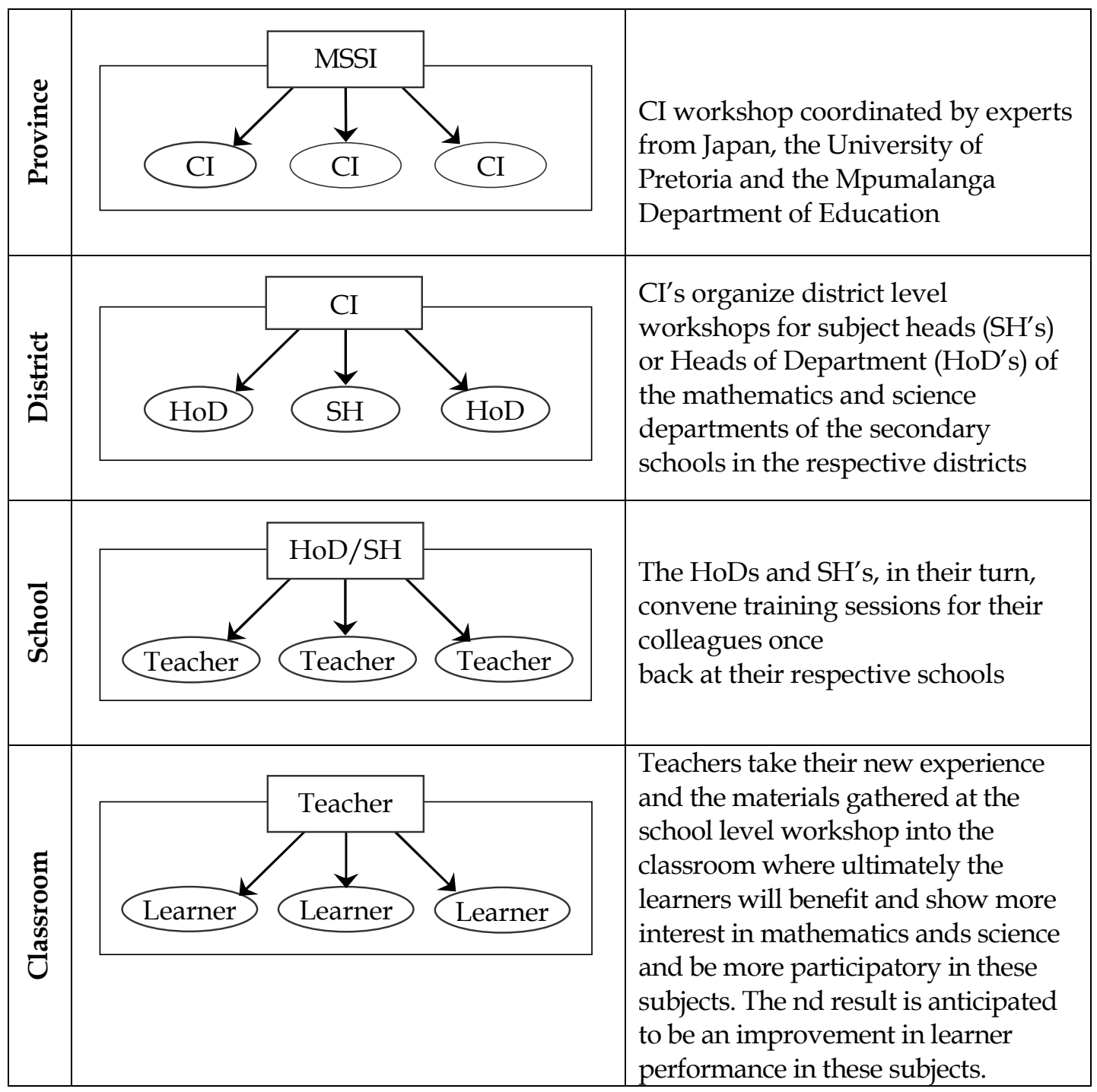

Figure 1.1 The Cascade Model used to convey new experience and materials from the level of MSSI coordinators to the learners

Most external aid for science and mathematics education provided to schools in South Africa is offered by NGOs and other donors from the private sector, and has been technology-based. Schools have been provided with computers, laboratory facilities or other materials and any training provided was for the use and application of the technology. The technology transfer model for such assistance assumes the existence of a 'technology gap' between the technology (in terms of both apparatus and how-to-knowledge) of supplier and recipient, and the transfer takes place to close the gap. The MSSI applied a new model of technical cooperation termed an 'experience-sharing model'. The experience- 
sharing model is applicable in situations in which there is no clearly definable 'technology gap'. This model was initially developed by the Japanese team organized to develop JICA's cooperation project for mathematics and science education assistance in Mpumalanga. The experience-sharing model is explained by Nagao (2004, p. 55) as follows:

'The cooperation takes place as a process in which the 'recipient' country picks and adopts useful elements from the technological experience of the 'supplier' country. The experience-sharing model is generally relevant in the areas of social development, such as education and health, where traditional and cultural values have such significant influences that cooperation needs and requirements may not be clearly discerned as a 'gap'. Since there already existed in South Africa a large body of knowledge, experience and know-how in the area of mathematics and science education, the cooperation need was for facilitating the accelerated development of mathematics and science education, particularly for the country's African population.'

The CI's underwent a 6-week group study in Japan in order to develop their own curriculum development skills, be exposed to relevant Japanese systems and to develop teacher and learner support materials. The support materials were to be used in South Africa in a retraining programme for teachers. On returning to South Africa, their training was supplemented with province wide workshops run by the coordinators of the MSSI, viz. the MDE, CSE and JICA representatives.

CI's ran district-level workshops for mathematics and science HoDs, where they trained the HoD's and SH's to use the support materials developed in Japan. Experts from the University of Pretoria and Japanese teams from the two participating Japanese universities, the University of Hiroshima and Naruto University of Education, assisted the CI's in these workshops. The workshops were held for one week per term per district and covered specifically identified problematic topics from the curriculum.

The HoD's in turn organized school-based workshops based on the programmes to which they had been exposed at the district-level sessions. They were assisted by the CI's who visited the schools to do classroom observations and assist in the classroom with implementation of principles, such as successful groupwork techniques, covered in the workshops. 
In addition to providing INSET, JICA agreed to fund a research project in which the implementation of C2005 in Mpumalanga schools would be evaluated in terms of a framework of implementation that was being developed by Rogan and Grayson. The aim of the research was to investigate how C2005 was being implemented in secondary schools in mathematics and general science and to offer suggestions on improving the introduction of innovations in a developing country. The study was to take place mainly in school districts where the MSSI curriculum project was already underway in order to monitor and evaluate the project. The principal investigators were from the CSE but at various points throughout the study, academics from The Netherlands, Japan, the USA and other South African universities also formed part of the research team. The CIs from the different districts were also invited to participate in the research for specific tasks such as data collection.

The MSSI thus had two major functions, firstly a curriculum implementation function where in-service training was carried out, and secondly a research function. The curriculum implementation project of the initiative started in October 1999 and the two projects ran concurrently after the research project started in January 2001. The first phase of both these projects was concluded in 2003. Data from 2002 and 2003 are used in this thesis.

\subsection{THE RESEARCH FOCUS}

Broadly stated, the study reported in this dissertation will focus on two areas:

1. It will firstly analyse the state of various relevant factors pertaining to C2005 uptake in Mpumalanga schools. These include the three constructs within the Rogan and Grayson implementation framework as well as their subconstructs.

2. Secondly it will investigate what the possible impact on implementation could be of:

- some influences outside of the school as well as;

- some factors that make up the fabric of the school.

The aim of this dissertation is to identify and analyse factors that may play a significant role in implementation of new curriculum policy. At an international level, this study will add to the literature on curriculum change, but with a 
distinctly unique flavour owing to the context of the research. The results of the study will be particularly important for the South African Education Department and in particular the MDE as it will shed some light on a how implementation might be secured after curriculum introduction. The funders, JICA, who spend much of their resources, in terms of manpower and money, in bringing about improvement in the teaching and learning of mathematics and general science, will be informed by the finding of this study. Providing indicators of success or failure could direct their efforts, making them more cost effective.

\subsection{STRUCTURE OF THE DISSERTATION}

This dissertation follows the order of reporting traditionally used in most scientific studies and indeed other quantitative studies carried out in the humanities. This introductory chapter is followed by the literature review, an explanation of the theoretical framework selected for the study, a methods chapter, a chapter describing the research samples adopted for the study, two results chapters and then a final concluding chapter in that order.

Chapter two is a literature survey of curriculum change. It looks at curriculum change throughout the world, with particular reference to science curricula, as the last thirty years has seen science curriculum change occurring globally. An investigation into curriculum change in Africa follows, which in turn is followed by a look at curriculum change in South Africa as it has progressed over the last 14 years since the demise of apartheid. The framework for the study is explained and expanded upon at the end of the chapter.

Chapter three explicates the theoretical framework selected to shape this study.

The fourth chapter covers the various methods used in the study. The design of the questionnaires used (for both qualitative and quantitative data collection), the data collection procedures, the data analysis and data manipulations are explained in detail.

Chapter five provides a description of the research samples adopted for the study. 
Chapter six reports the results of the simple statistical analyses of the questionnaire which provide the snapshot taken in 2003 of the state of various relevant elements pertaining to C2005 uptake in Mpumalanga schools. Some of the findings are corroborated with results from case studies carried out in 2002.

Chapter seven reports results from more complex statistical analyses that were employed to investigate what the possible impact on implementation could be of:

- some influences outside of the school as well as;

- some factors that make up the fabric of the school.

Chapter eight summarises the main findings of the results of the study. Issues arising from the results are discussed with particular reference to their usefulness in addressing problems with C2005 implementation and future implementations of curriculum changes in South Africa and other developing countries. Finally, recommendations for future research are made. 


\section{CHAPTER 2 \\ The context of curriculum change in South Africa}

South Africa's curriculum changes have not proceeded in isolation but have been influenced by global trends (2.1). In addition, changes in the rest of Africa after independence from colonial powers seemed to have an impact on what was going to happen in South Africa (2.2). After the withdrawal of the colonial powers from African countries, curricula for schools were overhauled to stamp a new national identity onto schooling in the newly independent countries. So too, would South Africa want to rid itself of previous governmental influence on schooling and replace it with a curriculum that would be representative of a new South Africa. The introduction of the new South African Curriculum, C2005, coincided with enormous political changes within the country (2.3). With very fast, major paradigm shifts occurring in curricula internationally as well as nationally, attempts have been made to understand the curriculum implementation process through deconstruction into contributing components. Some such attempts are investigated in section 2.4 of this chapter.

\subsection{INTERNATIONAL CURRICULUM CHANGE IN SCIENCE EDUCATION}

Although some authors (de Boer, 1998; Wallace \& Louden, 1998; Welch, 1979) refer to the post- Second World War period as the time when curriculum reform began, the 1950's provided tentative steps towards change. Fullan (1998, p. 215) describes this period as being '... relatively quiet for most of the decade.' Largescale curriculum reform began to take a more assertive foothold in Western education in the late 1950's (van den Akker, 1998) and by the 1960's was

'...thundering on the scene' (Fullan, 1998, p. 215) particularly in the areas of mathematics and science education. The reform came in waves, referred to simply as the first and second waves (Wallace \& Louden, 1998). 


\subsubsection{The first wave}

The first wave of curriculum change had its origins in the USA and the UK. The first wave took place with the belief that national security and competitiveness was dependent on knowledge of science and mathematics. After World War II, questions about the technical expertise of people and the education systems' ability to prepare individuals to work in technical fields were being raised. The Allies had been impressed by the technical prowess of some of their opposition during the war and there was a need to stay ahead in terms of technology.

Sputnik, the Russian satellite launched in 1957, provided further impetus to the growing need for curriculum change (Bybee \& de Boer, 1994). With the Russians having been the first to launch a satellite, the West felt concerned that their security was threatened. Even more impetus for change was created by President John Kennedy's ambition for the USA to put the first man on the moon (Bybee, 1998). This endeavour would require enormous expertise. Bybee (1998) states that as a result of the need to stay ahead in the cold war, curriculum reformers were required to replace the content of topics and information with a curriculum based on the conceptually fundamental ideas and the modes of scientific inquiry and mathematical problem solving.'

Although this wave of change was politically motivated, the task of formulating the new curriculum was given to senior scholars in science faculties associated with the many of the top universities and other prestigious institutions curriculum writers who were not associated with the government or party politics. They produced programs and materials and worked along with teachers and other educators in an effort to bring about reform. Fullan (2007) has dubbed this first wave period the 'adoption era' because the aim was narrowly focussed on getting innovations out into schools in the hope that they would bring about the change. In the USA, the NSF (National Science Foundation) funded summer institutes to encourage the implementation of these new curricula (Welch, 1979). In the UK similar implementation projects were created under the auspices of the Nuffield Foundation.

In many cases innovations were superficially adopted with some of the language and structure of the innovation being included in the vocabulary of the teachers, but not in their teaching practice (Bybee, 1998). Policies at the state and local levels were not put into place to sustain changes which resulted in less than 
complete uptake of the change. Also, teacher educators were not directly involved in the reform and consequently without a sense of ownership, were slow in supporting the changes by revising teacher qualification assessment, undergraduate teacher education and INSET for qualified teachers (Bybee, 1998). The end of the first wave is defined differently by different authors. In the USA the end of the first wave of curriculum reform is attributed by Bybee (1998) to the public outcry against an anthropology program, Man a Course of Study, which stirred conservative critics. However, Fullan (2007) cites several studies carried out in the early 70's that indicated that the first wave of reform had achieved little of the desired outcome. Fullan (2000, p 5) is more direct in his description of the demise of the first wave in his statement that the first wave of reform "...failed to make a difference largely because advocates of reform ignored issues of implementation and did not address local institutions and cultures." The understanding and focus of the concept of curriculum change were in general limited to creating syllabi and elaborate curriculum materials.

Other countries around the world experienced the first wave of curriculum change a little after the Anglo-American efforts. Many countries used the AngloAmerican example to structure their curriculum change processes. In several cases, existing materials were taken from British or American projects and adapted for use in different countries (van den Akker, 1998). As such, some of the experience gained in the implementation procedures in these two countries led to improvements. For example, more attention was paid to the pedagogical aspects in secondary science projects, to societal issues and to the links between science and other fields (van den Akker, 1998). Again, as in the case of the USA and the UK, there was only a limited success in uptake of new teaching innovations.

\subsubsection{The second wave}

Having learned from the limited success of the first wave, curriculum developers from the second wave acknowledged that the concept of curriculum was more than documents in isolation; that it should relate to more components involved in the education processes such as personal, historical and applied aspects of science in the study of science. Wallace and Louden (1998) state that a characteristic of the second wave of curriculum change emphasised scientific literacy in addition to scientific knowledge. Another difference between the first wave and the second wave is the shift from curriculum and curriculum materials 
being imposed on teachers to the building up of the capacities of teachers in order to improve teaching in the classroom (Nagao et al, 2007).

Another of the lessons learned about curriculum reform after the first wave, was that there are more components within an education system that affect curriculum implementation than just the curriculum materials or teacher support (Kapp, 1997). The new awareness of a multiplicity of factors led to the coining of a new adjective in order to better describe reform and distinguish it from past reforms i.e. systemic reform (Smith \& O'Day, 1990). The term systemic implies that reform takes place within a system of components. Implicit in this definition therefore is the fact that reform should not be studied in isolation. It should be studied rather as a sum of the components within the system considered in their own right and in particular their interrelationships. There is recognition that reform is a complex and dynamic process, not a mere adoption of a new set of curriculum guidelines. The 1990's heralded a global change climate for education that was more considerate of the whole process of change rather than its goals only. Both the first and the second waves of curriculum reform that occurred globally impacted on education in Africa. Curriculum change of the sixties coincided with many African states gaining independence from colonial powers. The consequences of this coincidence are expanded on below.

\subsection{CURRICULUM CHANGE IN SUB-SAHARAN AFRICA}

In the following section, sub-Saharan Africa excluding South Africa is considered. South Africa was politically isolated from the West during this period because of sanctions related to the policy of apartheid. Also, the South African government did not participate with the rest of Africa in any social development initiatives like education development.

Curriculum change in Africa was influenced by the West. Before the arrival of the colonial powers, African countries had their own indigenous form of education with its own traditional pedagogy firmly based within a cultural perspective (Marah, 2006). Osaki (2002) describes this form of education as being propagated by the oral tradition, focusing on understanding and finding harmony with nature through knowledge of plants, animals, soils and environments around the community. Teaching was mainly informal but formal systems run by local 
experts, usually elders, were found. However, the knowledge was not fixed nor written down but was utilitarian and dynamic. Sensitive forms of knowledge were controlled by individual families and passed on from parents to specially selected young members. Knowledge was remembered, not recorded, and told, not written down.

Western education arrived in the 1800s with colonization and became included in the education system soon afterwards (Prophet, 1990). Western education brought another type of education: a formal education with the new skills of reading, writing and mathematics. The old traditional education was displaced and was not reinstated after independence. Prophet (1990, p. 15) explains what occurred after independence by saying:

When considering 'development' as the route to modernisation it was to the former colonial education system that the new countries [those having achieved independence from colonial powers] turned rather than to the traditional forms, and so started an era of 'academic imperialism' which still holds sway throughout Africa.

Samoff (1995) defines three common pressures behind changing education in Africa after the withdrawal of colonial powers. Firstly, the new national government committed itself to education as a basic right of citizenship. Secondly, there was a strong perception that education was the main route to individual and social benefits. Thirdly, more schools were needed to develop a source of citizens who were well skilled and who could help the country progress.

UNESCO made important contributions to curriculum thought in sub-Saharan Africa, particularly through its Ministers of Education in Africa (MINEDAF) series from 1961 to 1991. A table listing the conferences held in this series and the outcomes and discussions held at these conferences (adapted from Obanya, 1994) can be found in Appendix 1. What is remarkable is that over the thirty-year period that UNESCO ran these conferences, very little advancement was made on the commitments made at the first conference (Obanya, 1994). Ogunniyi (1986, p. 111) states that the curriculum in most of Africa in the 1950's and 1960's "...was in the form of syllabuses of the different subjects primarily set up for examination purposes." With the gaining of political independence in many African countries, African leaders gradually evolved a pan-African policy on education and in particular, science education. Previously, science content was 
derived from Western science teaching programs and was taught as dogma, not in an inquiry orientated paradigm - the kind of science education that did not fit with new African aspirations (Ogunniyi, 1986).

In Ogunniyi's opinion, a conference held in 1961 at the Massachusetts Institute of Technology (MIT) in the USA laid the foundation of curriculum development in science and mathematics in Africa. Subsequently several organisations, mainly from the USA and Europe (including UNESCO), provided support for science curriculum development throughout Africa. Much of the curriculum change that occurred was carried out under the auspices of aid programs, by expatriates with a First World mind set and without a contextual feel for the countries they were working in (Gray, 1999). As a result, curriculum development efforts in the West contributed significantly to the development and growth of science education programs all over Africa (Ogunniyi, 1986; Prophet, 1990).

The slow and limited success of curriculum reform efforts in Africa was confirmed by another conference held in 1980. Most of the participants in the Inaugural Conference of Science Educators (1980) complained about the poor state of science teaching in their countries. Yoloye and Bajah (1981) reported that most African countries had not been able to achieve the improvement in science education anticipated since the '60's despite some efforts to improve science teaching. This is a pessimist's view. An optimist's view such as that of Lewin and Dunne (2000) acknowledges that curriculum reform in Africa during this period had replaced colonial material with nationally determined content and learning objectives - albeit to a lesser extent than was hoped.

There is substantial similarity in the curricula of African countries and others in the West. One main reason was that curriculum change was influenced by Western institutions through financial and manpower support in Africa. Another reason is that both advanced and developing countries throughout the world have developed similar curricula. Sifuna (1992, p. 6) gives the following rationale for this observation:

An important link between some developments is vocationalism or the orientation of education around the preparation for labour markets. It has become an international trend which transcends the divide between rich and poor countries, and it is manifest both in socialist countries and liberal democracies. 
The period in Africa since the 1960's has been fraught with political turmoil. Independence in many cases did not automatically mean peace and prosperity in all African countries. New governments provided unstable political climates in some of the countries that were attempting to take ownership of their curricula. While the nation was still not at peace with itself, changing curricula was a more daunting task and more difficult to achieve than it is under normal circumstances.

Curriculum reform was treated as an integral part of nation-building in African states since their independence; a precedent South Africa was going to follow. Two recent World Bank reports (Ottevanger, de Feiter \& van den Akker, 2008; Leyendecker et al, 2008; Ottevanger \& van den Akker, 2008) portray and discuss the current status of curriculum in sub-Saharan Africa. Although many curriculum reforms speak of changes in teaching methods, such as learnercentredness, implementation has still not occurred. Facilities remain poorly resourced, especially in rural areas. Class sizes range from too big to too small to be effective in many places. There is a need for teacher support materials to help teachers with new curriculum innovation. Where such materials are available, there is evidence that, for various reasons, they do not achieve their potential for change. Textbook supply is erratic, especially in rural schools.

Curriculum reform in Africa was initially rooted in the need to change education to better suit citizens of a new country after independence from a colonial power; a change made at the macro-level (the system level where curriculum is often politically driven, aiming to bring about major changes (van den Akker, 2005)). Thereafter change was aimed at improving education at meso (changes at the school level) and micro-levels (changes at the classroom level). South Africa was going to repeat the act of change to signal release from past rule. After immediate cosmetic changes to the existing curriculum in 1994, in 1997 a new curriculum became policy (macro-level change). This new curriculum was soon reviewed in the effort to improve education - attempting meso- and micro-level changes.

\subsection{C2005 AND POLITICAL CHANGE IN SOUTH AFRICA}

As stated above, by the early 1990's curricula throughout the world were being revamped. Curricula incorporating learner-centredness and outcomes based education were debated and introduced in varying degrees in many different 
countries both in the West and in Africa (Chisholm \& Leyendecker, 2008). It was also a politically sensitive time in South Africa with the demise of apartheid imminent. The African National Congress (ANC) which was the party that would come into power in 1994, had developed a philosophy of 'Peoples Education' as a result of the turmoil in black schools through the 1970s and 1980s. With education often being a political tool for social structuring it was clear that a new curriculum would have to be sought for South Africa that would serve a new and radically different purpose (Harley \& Wedekind, 2004). A new curriculum would have to be seen as totally different from the old one to fulfil its function of forming a new South African society.

A new vision in policy creation was beginning to take hold during the transition period whereby policy was formed by stakeholders from business and industry rather than institutions such as education departments (Chisholm, 2003; Jansen, 1999a). Progressive academics and politicians began to discuss curriculum reconstruction for a new society before the 1994 elections (Nzimande, 1997). This led to the formation of the National Education Policy Initiative (NEPI), which set about developing proposals for the restructuring of the formal education system. The NEPI reports and framework which were published by 1992, having drawn on discussions with a wide variety of interested parties, stressed the need for a unitary system of education and training. The NEPI reports proposed nonracism, non-sexism, democracy, equality and redress as principles to underpin a new curriculum.

With the elections of April 27, 1994, a new Government of National Unity was formed under President Nelson Mandela. One of the first tasks undertaken by the new government in terms of education was the merging of all the different education departments into a single Department of Education with Departmental Offices for each of the newly defined nine provinces. Under apartheid, there had been a total of 19 education departments catering for different race groups, viz. White, Black, Coloured and Indian, and different provinces (Harber, 2001). These were dismantled immediately. The racial divide in education was officially eradicated. The variations between the curricula for different groups were also to be eradicated (Harley \& Wedekind, 2004; Jansen, 1999c).

Chisholm (2003) defines three main phases through which curriculum reform would progress over the next decade: 
- cleansing of the existing curriculum of its racist and sexist elements;

- implementation of outcomes-based education through the development and implementation of $\mathrm{C} 2005$;

- review and revision of C2005 in the light of recommendations made by a ministerial review committee appointed in 2000.

Although there had been some talk and suggestions about a new education system prior to the elections, no curriculum documents had been prepared. With nothing already in place in terms of school curricula, but an urgent political need to be seen to be making sweeping changes, temporary changes to the old apartheid curriculum had to be brought about immediately. These short-term curriculum revisions were undertaken as it was acknowledged that the establishment of a long-term curriculum framework would take at least two to three years to establish (Jansen, 1999c). In late August 1994 curriculum revision began throughout South Africa. The old curriculum was to be edited and continued within the short term. It had to be purged of racially offensive, sexist and outdated content.

Jansen (1999a) states that many parties have agreed that this short-term revision should not have occurred. The time frame for implementation was unrealistic. The changes were made in late 1994 and were expected to be implemented in January 1995. In addition, within the political realm, this effort was deemed a '...bland and minimalist reform of the apartheid curriculum.' (Jansen 1999c, p. 60). There were three main outcomes of the initial curriculum review (Jansen, 1999c):

- non-change - there were no changes made at all, e.g. in the languages;

- editorial adjustments - e.g. the addition of an introductory overview for English;

- topic reshuffling - new topics added, others de-emphasised e.g. a reduction in European history and increase in African Nationalism in the history curriculum.

Schools carried on operating as previously despite the attempts to 'cleanse' the curriculum. Most of the crude racism that was in the old curriculum had been 'quietly removed in the early 1990s.'(Jansen, 1999c). The 'cleansing' of the curriculum of its sexist and racist elements had been all but completed by 1994, giving the new government less to visibly change.

The perception of failure to bring about adequate curriculum change at this early point is reflected in what a teacher representative stated: 
'Curriculum change does not happen overnight, and at the rate we are going in South Africa the real danger is that we will be weighed down [by] the burden of Christian National Education for a long time...The bureaucrats are quite happy to pass off subject revisions as curriculum change because it does not even begin to rock their boat. In fact they are enthused by it all as they now have an opportunity to gain legitimacy in schools as being part of the new which is really the old.' (SADTU, 1995)

However, by 1995, the new united Department of Education brought out a White Paper where its determination to rid the country of the previous prejudiced approach in education was clearly set out in the statement:

'It is time to declare that a new era has dawned. In publishing this document, the Ministry of Education opens not just a new chapter but an entirely new volume in the country's educational development'. (Department of Education, RSA, 1995.)

On the $24^{\text {th }}$ of March 1997, a new curriculum was launched. It was dubbed Curriculum 2005 (or C2005) as it was anticipated that by 2005, all sectors of schooling would be covered by it. It was to begin in the first year of primary and secondary school in 1998 and would be completely adopted by 2005, the seven years it takes for a child to complete primary school education in South Africa (Harber, 2001).

C2005 had three elements which characterised it at the meso-level;

- It was outcomes-based. With OBE being perceived by some decision makers in South Africa as a state-of-the-art educational innovation worldwide, it was inevitable that OBE would form part of a new curriculum for South African schools.

- It introduced an integrated knowledge system.

- It promoted learner-centred pedagogies.

OBE was seen by C2005 curriculum writers as the "pedagogical route out of apartheid education" (Chisholm, 2003). Chisholm shows that the contrast OBE offered to the previous curriculum was that it emphasised results, outcomes and their achievability being subject-bound and content laden as the in the past. OBE and C2005 provided a new broad framework for the development of an 
alternative to apartheid education that was open, non-prescriptive and reliant on teachers creating their own learning programmes and learning support materials (DoE, 1997). Rogan (2006, p.97) states with regards C2005's embracing of OBE:

The rationale is that for too long South African students have memorised content, which they then regurgitate in tests and examinations. With the introduction of OBE, the focus supposedly shifts to what they can do with their knowledge, and in particular whether they can use what they know to meet the specified outcomes.

C2005 was impressed upon a largely grateful public by a government determined to change everything as quickly as possible for the betterment of the South African Society. The new curriculum was received with enthusiasm by teachers in principle as it signalled the end of the old and the beginning of a new, freer existence. However, C2005 was almost immediately problematic. The meso-, micro- and nano- (changes relating to the individual and his or her responsibility for learning) levels of curriculum design and implementation had up to this point largely been ignored in the politically inspired rush to bring equity into education. Harley and Wedekind (2004, p. 199) succinctly sum up the reason:

\footnotetext{
"The new curriculum did not emerge from debates within the education sector about the most appropriate forms of pedagogy to bring about the new political vision, or about what was feasible in the profoundly diverse and unequal range of schools.'
}

Any previous discussions with academics were pertinent to the macro level of curriculum design; further discussion down the levels had not taken place or if they had, were ignored. McGrath (1998, p. 503) is blunt in his statement;

“...this exercise [curriculum reformation] has tended to place too little emphasis upon the realities within the institutions that will be expected to deliver on the change and lacks a coherent view of the possibilities for policy delivery within these institutions."

Teachers had to be trained for the paradigm shift required by the new curriculum. "OBE training" for teachers was introduced in what was in effect a crash-course, given the very short time allocated between C2005 development and its 
implementation. The cascade model of training was adopted with a range of consultants and non-governmental organisation (NGO's) being sub-contracted to do the training. Many of these trainers were ill-equipped themselves to provide the training and the teachers within the cascade were in turn ill-equipped to replicate the training within the cascade models. Several misconceptions about C2005 emerged as a result of the panicked training (Aldous, 2004). Group work, as a vehicle for learner centredness, soon "...became the major symbolic identifier of the new curriculum, and for many teachers, implementing group work was the core pedagogical shift required of them by C2005" (Harley \& Wedekind, 2004, p 200). Rogan (2004) adds that another source of difficulty for teachers was the dictum that content was not important; that any content could be selected at any time and at any grade level, as long as the outcomes were achieved.

Although teachers were enthusiastic about a new curriculum they were initially slow to endorse and adopt OBE. Some academics began exploring problems associated with the implementation of OBE. For example Jonathan Jansen in his chapter "Why OBE will fail" (1999b) gives 10 reasons why OBE would not live up to its promise in South Africa, among them being the complexity of the presentation of C2005. The implementation of C2005 in its original form was fraught with problems. It was too complex to be introduced in the expected timeframe, there was inadequate training and coordination of the implementation, there was insufficient competency for training and inadequate teacher development. Rogan (2007, p. 98) succinctly puts a reason to the initial failure of C2005 implementation by saying "...the policy directives lacked detail on how these ideals might be realised in practice. As various commentators have noted, the attention and energies of policymakers are focused on the 'what' of a desired educational change, neglecting the 'how'". Verspoor (1989, p 133) already commented before that "large-scale programs tend to emphasize adoption and neglect implementation." He continues by saying that "...in nearly all instances low outcomes resulted from poor implementation of what was essentially a good idea."

In 2000 a Ministerial Review Committee was appointed which 'recommended a major revision of the curriculum in order to make it more understandable in the classroom' (Chisholm, 2003, p. 2). It pointed out specific problems with C2005, notwithstanding the overwhelming support it had received by teachers. These included: 
- a skewed curriculum structure and design;

- lack of alignment between curriculum and assessment policy;

- inadequate orientation, training and development of teachers;

- learning support materials were variable in quality, often unavailable and not sufficiently used in classrooms;

- policy overload and limited transfer into classrooms;

- shortages of personnel and resources to implement and support C2005;

- inadequate recognition of curriculum as core business of education departments.

As a result of the Ministerial Review Committees findings, the Revised National Curriculum Statement (RNCS) was developed. The Minister of Education (at that time the second one in the new government) proposed that a review was necessary in the light of existing inequalities and the realities of under-resourced schools which had large classes and teachers largely untrained in learner-centred education and making their own curricula (Chisholm, 2003). To illustrate the political thrust behind C2005 it must be pointed out here that many of the Minister's own party criticised his move as being a return to apartheid education or an overturning of the first Minister of Education's work, rather than part of the iterative process of curriculum development.

There were many more influences and inputs into the creation of the RNCS with a bigger public input than ever before in any curriculum design process run in South Africa. Chisholm (2003) speaks of all the stakeholders in the revision process as 'voices' and sums up public input by stating that '...these voices with social power linked to the new state, amongst the babble of voices spoken and making an impact on the curriculum, that gave the Revised National Curriculum Statement its main discursive features: a rights-oriented, outcomes-based curriculum.' Other 'voices' were dominant in the revision process. These included the ANC, teacher unions and university-based individuals. The RNCS became policy in 2002 .

However, after the RNCS became policy, children were still far from receiving the intended curriculum. The curriculum implementation took on several forms. Rogan (2004) reported various classroom results in his aptly titled article "Out of the frying pan...? Case studies of the implementation of Curriculum 2005 in some science classrooms". In his analogies he describes classrooms: 
- where no change had occurred since the introduction of C2005; lessons were presented in the same way as they were prior to C2005 implementation;

- where trivial, meaningless tasks were given to the children as an interpretation of learner centredness and group work; teachers started the lesson off and then disinvolved themselves as the children were left to complete the task;

- where some innovation in the right direction was taking place, but in a shallow form resulting in inadequate attainment of the intended lesson;

- where some innovation is introduced but not followed through so that the attainment of the intended curriculum is inadequate;

- where there was some success in achieving more than one of the intended outcomes of the curriculum.

The diversity of schools, the inconsistent implementation of the RNCS and the inadequate transfer of the aims of the RNCS have all resulted in a variety of interpretations for implementation of C2005. Globally, implementation is a problem for reasons that are place-specific or generic. In order to understand this unequal incorporation of innovation, it is necessary to break down the elements that contribute to curriculum reform. To this end researchers have formulated frameworks or models in order to make sense of the multiplicity of the process of implementation.

\subsection{DECONSTRUCTING CURRICULUM IMPLEMENTATION}

An important observation made by Fullan (2007) is that because large-scale reform was a relatively recent phenomenon globally, the knowledge base around implementation was still evolving. An added complication to making sense of the maelstrom of developing knowledge about curriculum change was the recognition that there are many impacting components that affect curriculum change efforts (van den Akker, 1994) and that these may not all be controllable by the curriculum designers.

Some researchers, in efforts to evaluate large-scale reforms have attempted to define some of the components and look at them in isolation as well as in the context of the whole curriculum change effort. Researchers in many cases designed their own frameworks or models of systemic change in order make sense of the variety of impacting components. These models defined some of the 
components and in some cases enabled researchers to operationalise the components in order to research them in their contexts.

By creating models, the researchers define areas that impact on curriculum change. These areas are termed factors, facets or constructs. What they are called is irrelevant, what is important is that deconstructing the phenomenon of curriculum change into smaller coherent factors that can be operationalised and measured, helps to understand curriculum change as a systemic process. Some examples of frameworks or models for curriculum change are discussed below.

\subsubsection{Some frameworks for curriculum change}

Prior to 1977, research into curriculum change had been focussed on specific influences. In 1977, Fullan and Pomfret carried out a meta-analysis of research on curriculum change and were able to extract from the literature which factors were the most important in influencing implementation. Since their study, other researchers have attempted to create frameworks or models which include many of the variables that influence implementation. Categorisation schemes for schools of different competencies were also derived in an effort to understand implementation. Some frameworks, models and categorisation methods are discussed below.

\section{Frameworks seeking impacting variables}

\section{Fullan and Pomfret}

After analyzing several curriculum implementation studies, Fullan and Pomfret (1977) identified four constructs, each containing a number of specific variables. These included

- the characteristics of the innovation,

- strategies and tactics used to bring about the implementation,

- the characteristics of the school and

- the characteristics of the macro political units.

The explicitness and complexity of the innovation are considered as characteristics of the innovation. Explicitness refers to the clarity of what is required to implement the innovation successfully. The more explicit the guidelines for innovation are, the more likely that the innovation will be implemented. Complexity refers to the difficulty, and sometimes perceived 
difficulty in using the innovation. The higher the degree of complexity, the less likely implementation will occur.

Strategies and tactics refer to the methods employed to introduce and implement the innovation. Fullan and Pomfret (1977) cite several studies that indicate that in-service training impacts the degree of implementation of an innovation. Their findings indicate that intensive training rather than single workshops is an important strategy for implementation. Resource support refers to the time and materials provided when the implementation starts. From the studies scrutinised, it was clear that lack of time and inadequate support materials were serious barriers to implementation. What they defined as feedback mechanisms in their framework included an interactive network of teachers, consultants, administrators, students, parents and others. Fullan and Pomfret (1977) suggested involvement of parents and learners as well as teachers in the implementation of an innovation as little research had included these parties as influential in implementation. These mechanisms are meant to identify difficulties encountered during implementation and provide support for addressing the problems. Peer-feedback in particular appears vital for working through the difficulties of implementation. Participation refers to the involvement of those who are expected to implement the innovation.

Characteristics of the schools where the implementation is to take place includes the adoption process, organisational climate, environmental support and demographic factors. Fullan and Pomfret discerned the data from the point of view of successful implementation. Where successful implementation occurred it was found that the adoption process followed a problem-solving approach, and that 'high morale of teachers, active support of principals and general support of superintendents' (p383) increases the chances of successful implementation. In terms of demographic data, it appeared that the age of the teachers and their level of education did not relate to effective implementation.

In 1983, Fullan modified this framework. The first two of the four constructs remained the same but some sub-constructs were removed and others were added. Under the characteristics of the innovation, scope of the innovation and quality of the materials were added. Implementation strategies included only staff development and monitoring and feedback. The third construct became 'District and School Factors' and included the nature of the adoption decision, district administration, the principal, teacher-teacher relations and parents. The fourth 
construct became 'Extraneous Factors' and included changes in district leadership, teacher strikes, shifts in population and funding changes. Interestingly, Fullan continued to use the 1977 version of the model publishing it again in 2008.

\section{Clune and Zucker et al}

Clune (1998) conducted a review of 9 SSI's (Statewide Systemic Initiatives) carried out in the USA in the 1990's and derived a model for assessing successful systemic uptake of an innovation. He states:

A good theory of systemic reform should model the indispensable elements of the central thesis of systemic reform: a policy system (including an unspecified mix of policies and intermediate organizations and activities) with strong influence on a rigourous curriculum as actually taught to all students (though possibly a differentiated curriculum) and corresponding measured high student performance and systemic reform: some set of activities that bring systemic policy into existence. These basic elements, shown schematically in causal relationship, look like this:

Systemic reform (SR), through its purposeful activities, leads to Systemic policy (SP), which leads to A rigorous implemented curriculum (SC) for all students, which leads to Measured high student achievement (SA) in the curriculum as taught

This kind of system is dynamic even in its fully mature state (requiring constant communication and adaptation), and even successful reform will likely proceed incrementally (with more reform leading to gradually stronger policies, leading to gradually stronger curriculum for more students and greater gains in student achievement), so that dynamic reform obviously should be represented as a causal sequence:

$$
\mathrm{SR} \rightarrow \mathrm{SP} \rightarrow \mathrm{SC} \rightarrow \mathrm{SA}
$$

The Clune model is not a model which takes into account any impacting factor as Zucker et al's (1998) does. Zucker et al (1998) developed a model in order to report on several SSI's in the USA. They isolated several areas that could impact on reform and organised them into a model that illustrates curriculum change through all the levels from the state through to the learner. This model depicts SSI Activities as affecting a foundation policy, which in turn affects teachers, 
schools and learner achievement. The data collection for the nine case studies studied by Clune followed the Zucker et al model (Figure 2.1). Data was gathered in each of the nine states according to implementation of the reform, effects on policy, effects on teachers and effects on students. These categories fitted into the four variables of the Clune model.

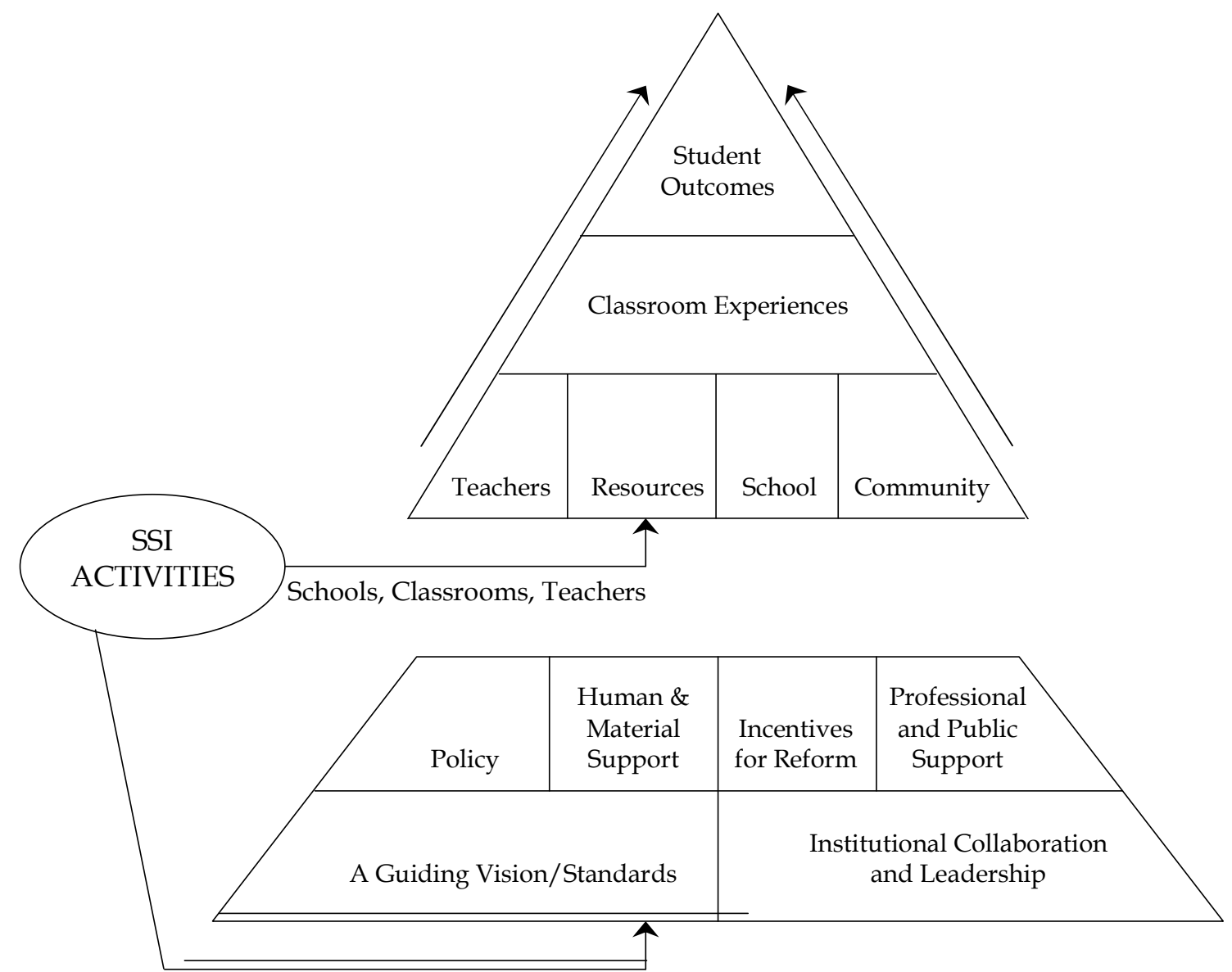

States, Regions, Districts

Figure 2.1 Zucker et al.'s (1998) model of Systemic Reform used to Guide SRI studies

\section{Walberg}

When studying curriculum implementation it is useful to consider Walberg's (1991) nine educational productivity factors, grouped into student aptitude, instruction and psychological environments. These are all factors that appear to increase learning. A model for curriculum implementation would take into consideration at least some of these productivity factors, if the ultimate aim of the curriculum is to improve learning or assess whether learning has improved. These nine factors include: 
Student aptitude

1 Ability or preferably prior achievement as measured by the usual learning tests

2 Development as indexed by chronological age or stage of maturation

3 Motivation or self concept as indicated by personality tests or the students willingness to persevere intensely on learning tasks

Instruction

4 The amount of time students engage in learning

5 The quality of the instructional experience including method (psychological) and curricular (content) aspects

Psychological environments

6 The 'curriculum of the home'

7 The morale or climate of the classroom social group

8 The peer group outside school

9 Minimum leisure-time television viewing

This framework is focussed mainly on the nano- level of curriculum implementation, looking at how the individual is affected by their own abilities and the environments they interact in. With large-scale curriculum implementation it will be impossible to influence all nine of these factors. However, factors such as the amount of time students engage in learning might be used as an avenue to implementation by providing the necessary time. The quality of the instructional experience might also be influenced in the implementation protocols along with the morale or climate of the classroom social group. Most of the other factors in the Wahlberg list cannot be affected directly by policy due to their very personal nature. However, what must be borne in mind, is that these factors do impact on implementation and therefore complete achievement of implementation for every student may not always be possible.

\section{$\underline{\text { Hopkins }}$}

Based on studies of several large scale education reforms in the UK such as the Cognitive Acceleration through Science Education (CASE) project and the Improving the Quality of Education for All (IQEA) project, David Hopkins (2000) developed a framework for school improvement that has as its central tenet, learner performance. His model is shown in Figure 2.2. It consists of four concentric rings with the central one being the learner achievement and progress. The next ring includes facets of good teaching which he terms the 'holy trinity' of 
teaching strategy, curriculum content and the learning needs of the learners. The third layer includes organisational conditions which are conducive to high levels of learning and teaching. It comprises collaborative planning that focuses on student outcome (e.g. Hargreaves \& Hopkins, 1991; Hopkins \& Gilchrist, 1998), staff development that is committed to the improvement of classroom practice (e.g. Joyce \& Showers, 1995), regular inquiry and reflection (e.g. Hopkins, 1993), and the involvement of students in their own learning (e.g. Rudduck et al, 1996). The outer ring is the context of the national reform agenda.

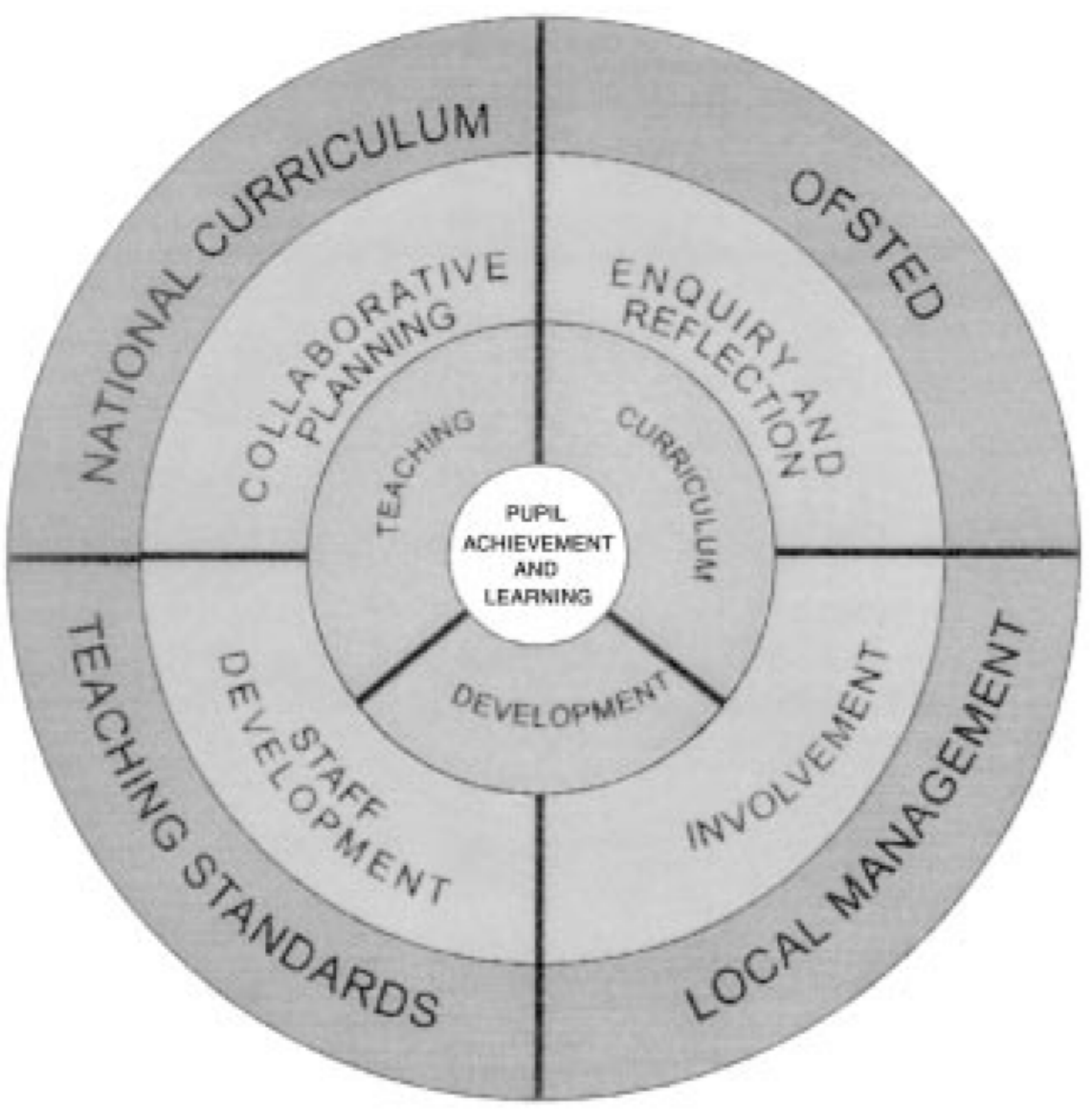

Figure 2.2 Hopkins' (2000) model for school improvement

The inside-out approach in the Hopkins model emphasises the learner outcome as most important when deciding on adopting innovations, i.e. there has to be a coherent pedagogical argument for the innovation rather that populist political ideology. 
Categorization schemes

School categorization schemes are useful extensions of the modelling process that help authorities to understand what implementation strategies are best suited to the different school contexts. It is recognised globally that schools are diverse in their abilities to implement curriculum and implement curriculum change (Harley \& Wedekind, 2004; Rogan, 2000). In an effort to understand how this diversity can be accommodated in a curriculum change scenario, there have been attempts to categorise schools and then treat them differently as the change is implemented (Beeby, 1966). Some categorization schemes are discussed below.

\section{$\underline{\text { Hopkins }}$}

Hopkins (1997) defines three categories of schools based on learner achievement;

- Type I which are failing schools,

- Type II which are moderately effective schools, and

- Type III which are effective schools.

He goes on to explain that differentiated interventions are required for the three types of schools for their improvement. For Type I schools, schools that cannot help themselves, assistance must be given to get them a level of moderate effectiveness, i.e. get them to become Type II Schools. A different approach would be taken to get Type II schools to the level of a Type III school. Type III schools are given interventions that help them to remain at the level of Type III.

\section{Beeby, Verspoor and $\mathrm{Wu}$}

The Beeby model categorised schools into stages viz. Dame School, Formalism, Transition and Meaning, a lower to higher stage grading reflecting the stages in incorporating better curricula and teaching methods, similar to Hopkins' three types. Verspoor and $\mathrm{Wu}$ (1990) developed a more comprehensive model, also with four categories, including factors beyond the school categorization factors such as teacher factors, curriculum factors and school factors. The Verspoor and $\mathrm{Wu}$ model included guidelines for improvement. Verspoor and $\mathrm{Wu}$ 's model proposed the four stages Unskilled, Mechanical, Routine and Professional to similarly categorise schools.

\section{Summary}

The models or frameworks mentioned above all have value when applied within the context they were designed for. Generally, a model has to be generic enough 
to be used in a wide variety of contexts. However, some research contexts are so different that a common model is impossible to apply across the board. In addition, the aim of the study may direct the structure of the model, making the models custom-designed in many cases. The Clune and Zucker models were independently drawn up for SSI studies in the USA, yet the models differ. Clune combined them in 1998 for his case study reports. A citation search carried out a decade after the models were published did not render any study that made use of the same models in other studies.

Where the school's context and the education system within which the school finds itself differ greatly, it is debatable whether models are transferable. Would models drawn up in the USA be transferable to the South African situation? This would depend to a large extent on the research to be undertaken. However, the variables that impact on curriculum change in South Africa are different to those in the USA. Montero-Sieburth (1992, p. 191) states that "...innovations cannot be transferred from one context to another as an instant technological 'fix'; understanding each particular context and its limitations is not only necessary but critical in curriculum reform." Hence a model drawn up to study and inform curriculum change in South Africa would necessarily contain some of the same factors, but also some unique ones. In addition the relative importance of factors will probably differ from one context to another.

Categorizing schools when there is such diversity does not necessarily yield useful groupings (Rogan, 2000). Critiques of categorization have proposed a developmental continuum model, stating that categorisation could be too generalised. In categorising schools or trying to find a place on a continuum for them, there are factors that affect implementation that have to be considered. The sum of these factors will place the school in its category or place on the continuum.

\subsubsection{Relationships between variables in models or frameworks}

In devising models to understand curriculum and its implementation, some researchers have chosen to set out in a diagram, the variables that need to be considered when introducing new curricula or bringing about curriculum changes. The visual placement of the variables in the diagram might imply a relationship with its nearest placed variable and this may or may not be indicated with an arrow. 


\section{International studies}

In the Zucker model, there are no arrows implying a relationship, but it is clear that a 'Guiding Vision' impacts 'Policy' and 'Human and Material Support' and that these latter variables impact 'Teachers' and 'Resources' and so on until 'Student Outcomes' is reached. In the Clune model there are arrows indicating a strict linear relationship, stating that systemic reform precedes systemic policy and so on.

In models where there are multiple impacting variables on a final outcome, there is an opportunity to test for relationships between the variables. Although for the Zucker model no research using it could be found in a citation search, there is evidence of research on the relationships between different variables it contains, albeit without regard to the model itself. To illustrate, examples are given below.

In looking at Zucker model, there is an implied relationship between 'Resources' and 'Student Outcomes'. Burtless (1996) edited an entire book on this issue with research indicating a paradoxical variety of findings. Intuitively, one would expect that there is a positive correlation between the resources available in a school and the student performance. Some chapters in Burtless's book find little evidence for this, indicating that additional school resources make little difference. However, other chapters show that children from well-resourced schools do better in the job market (the criterion for measuring 'better performance' in these studies) than children from poorly resourced schools. After perusing approximately 400 studies on student achievement, Hanushek (1997) found that that there was no strong or consistent relationship between student performance and school resources. Figlio (1999) found statistically significant evidence that school inputs are associated with student performance, at the same time noting these larger estimated effects of measured school inputs to be very small. These divergent findings emphasise the need to look at the context of the study.

Although the models discussed above have not lead directly to research on the relationships between different elements, they provide a structure in which to place elements in relation to each other and therefore the opportunity to investigate relationships between them. It is with this characteristic of a model in mind that the possible impact on implementation of some influences outside of the school as well as some factors that make up the fabric of the school is investigated in this thesis. However, a broader net for variables can be cast, that includes variables other than those included in the models above. 
Research in Mpumalanga

At the time this study got underway in 2003, there was a dearth of literature specific to the implementation of C2005 in South Africa as a whole as well as in Mpumalanga. Subsequently however, Zwane (2004) completed a minidissertation investigating problems encountered by educators with the implementation of C2005 in Grade 8 classrooms in township schools in the Bethal area. He interviewed forty teachers from five schools asking only six questions aimed at uncovering planning and assessment practices, resource use and availability, in-service training and perceptions and opinions teachers had about OBE. His study was not aimed at looking at any relationships between the factors he studied, he merely sought to gain a snapshot of what was happening at the time. Zwane found

- that there was a need for teachers to be trained in lesson planning.

- that teachers required training in assessment.

- that there were insufficiencies in the supply of resources.

- that teachers were poorly trained in the requirements of OBE.

- the attitude of teachers had not yet changed.

- that classroom management was poorly administered by educators.

- there was no effective teaching and learning in the five secondary schools sampled.

In short, in 2004, several years after the implementation of C2005, little had been achieved in terms of improving teaching and learning in the classrooms.

In 2006 Mbingo completed a mini-thesis on an investigation of the implementation of C2005 by foundation phase teachers in Bethal, the same Mpumalanga town in which Zwane had carried out his research. He interviewed nineteen foundation phase teachers in two primary schools mostly interrogating their thoughts and opinions about OBE also only aiming to glean a snapshot of the situation at the time. His study indicated that teachers were also still struggling with C2005 implementation and that the workshops provided for them were of little value. Trainers in the workshops were themselves ill-prepared to assist teachers. Teachers felt that the resources provided were inadequate and in many cases lacked coherence. The vocabulary of C2005 was also inaccessible. The HOD's of some of the Foundation Phases admitted that what was expected of teachers by C2005 was not clear despite documentation from the Department of Education and training provided. 
These two studies paint a rather gloomy picture of the state of C2005 implementation during the early years of this decade. It must be noted however, that both these studies were small scale and reflect findings within only one town of Mpumalanga. Within other districts within Mpumalanga the picture could be different.

\subsection{DESIGNING NEW FRAMEWORKS}

A comprehensive model for curriculum implementation would include not only the factors that influence schools such as physical resources, professional development, and monitoring. It would also include variables from the factors of Fullan and Pomfret, Clune, Zucker et al, Wahlberg and Hopkins that look at the broader picture and include factors such as school environment, school leadership and the role of the learners and parents in curriculum implementation. Rogan and Grayson (2003) proposed a framework that will be used as the model for this study that took into consideration many factors from across the spectrum of the education community as well as the need for consideration of the unique South African conditions. Chapter 3 of this dissertation will elaborate on the Rogan and Grayson framework and its application to this study. 


\section{CHAPTER 3}

\section{The conceptual framework of the study}

The research this thesis reports on was based on a framework designed by Rogan and Grayson in 2003 for the analysis of curriculum implementation in developing countries. This chapter looks in detail at the framework and how it was used in our research. In section 3.1 the framework is introduced along with some of the background to its development. The three constructs that make up the three points of the framework are explained in sections 3.2 to 3.4. In section 3.5 the use of the constructs in framing the study is elucidated.

\subsection{THE ROGAN-GRAYSON FRAMEWORK}

Curriculum change is often driven by top-down approaches that fail to take into account how the change may be enacted by teachers in the classroom. Verspoor (1989) states in his analysis of 21 World-Bank-supported educational change programs that "Large-scale programs tend to emphasize adoption and neglect implementation" (p. 133). Montero-Sieburth (1992) states that "this is partly the result of a lack of methodology for studying such factors [process in which a curriculum is perceived, interpreted and reconstructed by the teacher in the classroom] and also partly due to the fact that curriculum revision and goals are normally determined by planners and officials at national, state and local levels who regard what the teacher does as unimportant." (p. 179). Van den Akker (1994) explains that of the many variables that impact the success of curriculum innovation, only some can be influenced by the curriculum designers. These authors have implied the need for a context driven framework that looks at curriculum implementation at levels beyond the top levels of education bureaucracy and that look at several variables that could impact curriculum innovation. It seems that implementation strategies neglect the tools that teachers possess and those they lack in order to implement a new curriculum. They also tend to neglect the multitude of variables that may affect implementation. 
By 2003, Rogan and Grayson (2003) had identified that the progress of curriculum change in South Africa was difficult and slower than had been planned. The process of the C2005 roll-out had been 'hopelessly underestimated and inadequately resourced and supported' (p. 1173). Having identified the need to address implementation issues, Rogan and Grayson (2003) suggested that a theory of implementation ought to be developed for South Africa that might be transferrable to other developing countries. This theory would '....act as a guide for school-based practitioners, INSET providers and policy-makers' (p. 1173). In drawing up the theory their main aim was to address issues of particular relevance to developing countries, while drawing on international literature on educational change.

Rogan and Grayson (2003) proposed that a theory of implementation could be based on three major constructs viz. Profile of Implementation, Capacity to Innovate and Outside Influences. These three constructs can all be measured by means of indicators and are broad enough to include related factors, or subconstructs. Figure 3.1 puts these constructs and sub-constructs into a framework.

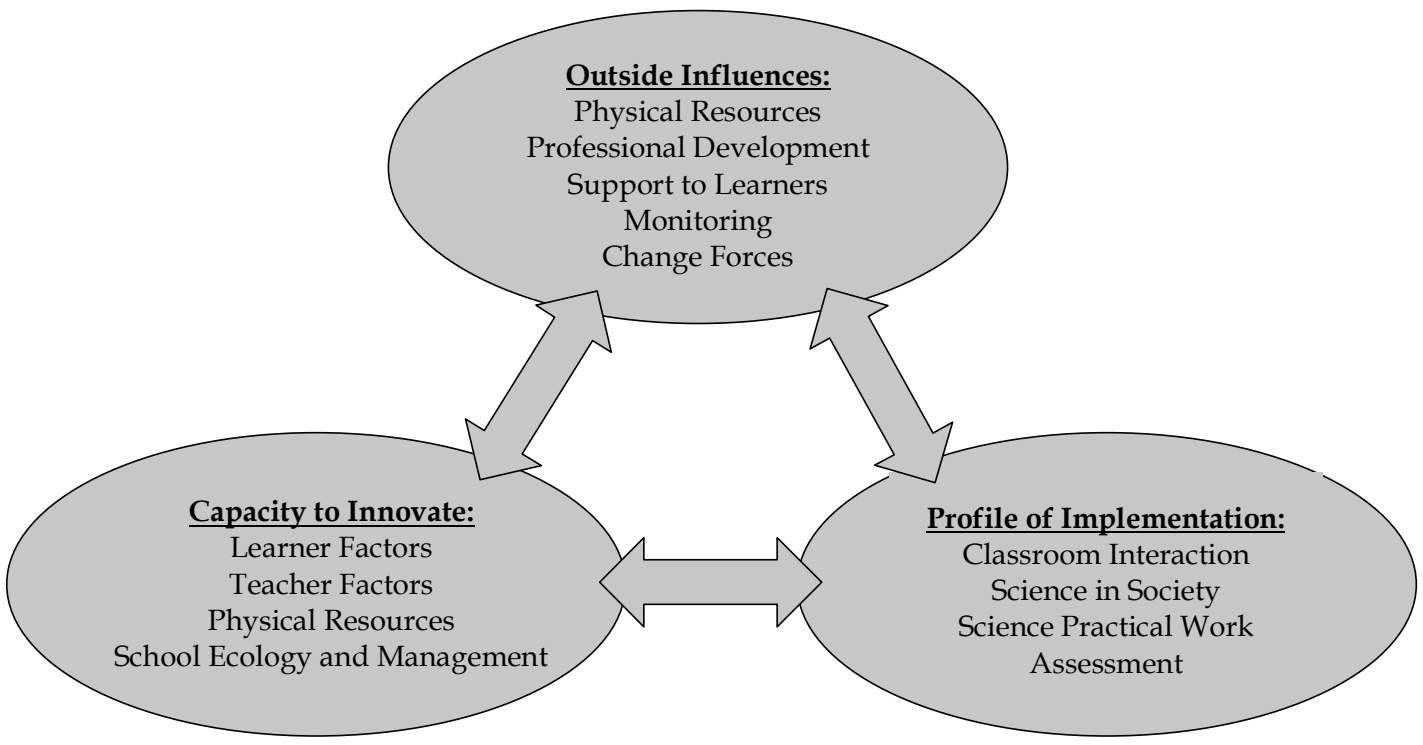

Figure 3.1 The constructs and sub-constructs of the Rogan-Grayson framework 
Linked with this diagrammatic representation of the framework is a definition of the sub-constructs that contribute towards the ideal for curriculum implementation represented in tables for each construct and its sub-constructs. See Tables 3.1, 3.2 and 3.3. As stated above, the sub-constructs can be measured by means of indicators. In the tables there are levels (indicators) within the subconstructs that show a move from traditional practices through to practices considered ideal within the new curriculum, a move from acceptable old practice (practice appropriate within the traditional goals and objectives-based curriculum) to an outcomes based approach. The movement through the levels indicates a gradual implementation of the changes required in the new curriculum, from traditional practice to the new practice required of the curriculum change. The tables were developed in the context of science and mathematics education in secondary education. Other tables could be developed in order to adapt the framework for other contexts such as social studies education.

It must be noted that the sub-construct 'Physical resources' occurs within both the Capacity to Innovate construct as well as the Outside Influences construct. Within the Capacity to Innovate construct physical resources refer to what is already available in terms of buildings, laboratories, libraries, curriculum materials, office equipment and grounds. Within Outside Influences, Physical resources refers to further provision of resources to supplement what exists within the schools.

\subsection{THE PROFILE OF IMPLEMENTATION}

The Profile of Implementation deconstructs into smaller elements in order to assess whether the new innovation is being enacted at the meso- and microlevels and to what extent. The profile is positively stated, including good teaching practice through the levels but with old curriculum practices allocated at level one, and the ideal new curriculum practices at level four. For level one therefore, learner centredness is beginning to be seen, mostly in a question and answer mode. Assessment is of the old fashioned written test type where mostly fact regurgitation occurs, but the tests are well designed and are beginning to ask some questions that require more than simple recall. As Fullan (2007) points out, a key feature of the practicality of implementation is the 'presence of the next 
steps.' This point has been incorporated into the profile in the levels from one to four, providing levels where partial implementation can be strived for and achieved in manageable steps as teachers move towards full implementation of a new curriculum. The value of the Profile of Implementation is that it will enable teachers as curriculum planners to determine where they are in terms of incorporating new practices. They can then consider the context and capacity of their school, and plan towards a meaningful implementation of C2005, phased in over time.

Rogan and Grayson specifically focussed on an inclusive development framework. Unlike some developmental models (for example Beeby, 1966), level one in their framework does not describe the 'lowest type of practice', but rather a good "transmission type lesson" that was indicative of previous curriculum requirements. It is quite possible that there are schools that do not display any of the practices in any of the dimensions or levels of the profile; that their practices did not reflect the quality required of level one. The higher levels are inclusive of the lower ones in the case of the Rogan-Grayson framework. Progression is seen as the judicious integration of the higher level practices over time. Hence the levels are not prescriptive of what should be done at any given point in time, but rather suggest the mastery and use of an ever-increasing array of teaching and learning strategies.

Table 3.1 (from Rogan \& Grayson, 2004) shows an example of what the profile of implementation could look like for the general science learning area for C2005. For the framework to be transferable and to be used in other contexts, the table is not seen as prescriptive for all contexts. Table 3.1 was drawn up specifically for the context of the research for the MSSI project. The sub-construct 'classroom interaction' and 'assessment' are generic to all learning areas. 'Science practical work' and 'science in society' were central tenets of C2005. The sub-construct levels in the table relate directly to C2005. Each sub-construct is explained below the table. 
Table 3.1 Profile of Implementation contextualised for the Natural Science Learning Area of South Africa's Curriculum 2005

\begin{tabular}{|c|c|c|c|c|}
\hline Level & Classroom Interaction & Science Practical Work & Science in Society & Assessment \\
\hline 1 & $\begin{array}{l}\text { Teacher: } \\
\text { Presents content in a well organised, } \\
\text { correct and well sequenced manner, } \\
\text { based on a well designed lesson plan. } \\
\text { Provides adequate notes. } \\
\text { Uses textbook effectively. } \\
\text { Engages learners with questions. } \\
\text { Learners: } \\
\text { Stay attentive and engaged. } \\
\text { Respond to and initiate questions. }\end{array}$ & $\begin{array}{l}\text { Teacher uses classroom demon- } \\
\text { strations to help develop concepts. } \\
\text { Teacher uses specimens found in } \\
\text { the local environment to illustrate } \\
\text { lessons. }\end{array}$ & $\begin{array}{l}\text { Teacher uses examples and } \\
\text { applications from everyday life to } \\
\text { illustrate scientific concepts. } \\
\text { Learners ask questions about } \\
\text { science in the context of everyday } \\
\text { life. }\end{array}$ & $\begin{array}{l}\text { Written tests are given that cover } \\
\text { the topic adequately. } \\
\text { While most questions are of the } \\
\text { recall type, some require higher } \\
\text { order thinking. } \\
\text { Tests are marked and returned } \\
\text { promptly. }\end{array}$ \\
\hline 2 & $\begin{array}{l}\text { Teacher: } \\
\text { Textbooks are used along with other } \\
\text { resources. } \\
\text { Engages learners with questions that } \\
\text { encourage in depth thinking. } \\
\text { Learners: } \\
\text { Use additional (to text book) sources } \\
\text { of information in compiling notes. } \\
\text { Engage in meaningful group work. } \\
\text { On own initiative, offer a contribu- } \\
\text { tion to the lesson. }\end{array}$ & $\begin{array}{l}\text { Teacher uses demonstrations to } \\
\text { promote a limited form of inquiry. } \\
\text { Some learners assist in planning } \\
\text { and performing the demonstra- } \\
\text { tions. } \\
\text { Learners participate in closed } \\
\text { (cook-book) practical work. } \\
\text { Learners communicate data using } \\
\text { graphs and tables. }\end{array}$ & $\begin{array}{l}\text { Teacher bases a lesson (or lessons) } \\
\text { on a specific problem or issue } \\
\text { faced by the local community. } \\
\text { Teacher assists learners to explore } \\
\text { the explanations of scientific } \\
\text { phenomena by different cultural } \\
\text { groups. }\end{array}$ & $\begin{array}{l}\text { Written tests include at least } 50 \% \\
\text { of the questions that require } \\
\text { comprehension, application and } \\
\text { analysis. } \\
\text { Some of the questions are based } \\
\text { on practical work. }\end{array}$ \\
\hline
\end{tabular}


Table 3.1 Profile of Implementation contextualised for the Natural Science Learning Area of South Africa's Curriculum 2005 (Continued)

\begin{tabular}{|c|c|c|c|c|}
\hline Level & Classroom Interaction & Science Practical Work & Science in Society & Assessment \\
\hline 3 & $\begin{array}{l}\text { Teacher: } \\
\text { Probes learners' prior knowledge. } \\
\text { Structures learning activities along } \\
\text { "good practice" lines (knowledge is } \\
\text { constructed, is relevant, and is based } \\
\text { on problem solving techniques.) } \\
\text { Introduces learners to the evolving } \\
\text { nature of scientific knowledge. } \\
\text { Learners: } \\
\text { Engage in minds-on learning } \\
\text { activities. } \\
\text { Make own notes on the concepts } \\
\text { learned from doing these activities. }\end{array}$ & $\begin{array}{l}\text { Teacher designs practical work in } \\
\text { such a way as to encourage learner } \\
\text { discovery of information. } \\
\text { Learners perform 'guided disco- } \\
\text { very' type practical work in small } \\
\text { groups, engaging in hands-on } \\
\text { activities. } \\
\text { Learners can write a scientific } \\
\text { report in which they can justify } \\
\text { their conclusions in terms of the } \\
\text { data collected. }\end{array}$ & $\begin{array}{l}\text { Learners actively investigate the } \\
\text { application of science and techno- } \\
\text { logy in their own environment, } \\
\text { mainly by means of data gathering } \\
\text { methods such as surveys. } \\
\text { Examples here might include an } \\
\text { audit of energy use or career } \\
\text { opportunities that require a } \\
\text { scientific background. }\end{array}$ & $\begin{array}{l}\text { Written tests include questions } \\
\text { based on seen or unseen 'guided } \\
\text { discovery' type activities. } \\
\text { Assessment is based on more than } \\
\text { written tests. Other forms of } \\
\text { assessment might include: } \\
\text { reports on activities undertaken; } \\
\text { creation of charts and improvised } \\
\text { apparatus; reports on extra } \\
\text { reading assignments. }\end{array}$ \\
\hline 4 & $\begin{array}{l}\text { Learners: } \\
\text { Take major responsibility for their } \\
\text { own learning; partake in the planning } \\
\text { and assessment of their own learning. } \\
\text { Undertake long term and commu- } \\
\text { nity-based investigations projects. } \\
\text { Teacher: } \\
\text { Facilitates learners as they design } \\
\text { and undertake long-term investi- } \\
\text { gations and projects. } \\
\text { Assists learners to weigh up the } \\
\text { merits of different theories that } \\
\text { attempt to explain the same } \\
\text { phenomena. }\end{array}$ & $\begin{array}{l}\text { Learners design and do their own } \\
\text { 'open' investigations. } \\
\text { They reflect on the quality of the } \\
\text { design and collected data, and } \\
\text { make improvements. } \\
\text { Learners can interpret data in } \\
\text { support of competing theories or } \\
\text { explanations. }\end{array}$ & $\begin{array}{l}\text { Learners actively undertake a } \\
\text { project in their local community in } \\
\text { which they apply science to tackle } \\
\text { a specific problem or to meet a } \\
\text { specific need. An example might } \\
\text { be on growing a new type of crop } \\
\text { to increase the income of the } \\
\text { community. } \\
\text { Learners explore the long term } \\
\text { effects of community projects. For } \\
\text { example, a project may have a } \\
\text { short-term benefit but result in } \\
\text { long term detrimental effects. }\end{array}$ & $\begin{array}{l}\text { Performance on open investiga- } \\
\text { tions and community -based } \\
\text { projects are included in the final } \\
\text { assessment. } \\
\text { Learners create portfolios to } \\
\text { represent their 'best' work. }\end{array}$ \\
\hline
\end{tabular}


- Classroom Interaction is a sub-construct that attempts to provide a visualisation of what one would observe happening in a classroom with the learners and teachers as the C2005 innovations are incorporated into classroom practice. The different levels act as an indicator of how much the teaching/learning transaction is moving from teacher centred to learner centred.

- Science Practical Work similarly illustrates a progression from teacher demonstrations to learners actively carrying out experimental work on their own.

- Science in Society was a new outcome introduced into the curriculum for the first time. There were very few ready-made resources that could be used to introduce this new area. Teachers were expected to be inventive in their ways of incorporating this new outcome. The profile attempts to define how this outcome could be incorporated into science teaching and also used to assess how successfully teachers are incorporating it.

- Change in the Assessment was another big factor brought in by C2005. There was to be a paradigm shift from pencil and paper knowledge testing to continuous assessment and outcomes based assessment.

The Profile of Implementation can be used for various purposes. It can be used for teachers' self-evaluation in order to gauge their own implementation of change. It can also act as a guide to them by providing the next step en route to complete implementation. For this study it will be used to analyse the practice of 323 teachers through self reported data. In terms of the profile's ability to analyse practice, the sub-constructs are independent of each another. For example, the classroom interaction approaches may be at level three in a given situation, but the assessment practices may be at level one. However, in such a situation it might be obvious that there is a lack of congruence between the curriculum as it is experienced and practiced in the classroom, and how it is being assessed. Such a lack of correspondence could well provide a warning to school-based practitioners. 


\subsection{CAPACITY TO INNOVATE}

The construct Capacity to Innovate elaborates on some support factors that may have an impact on the implementation of a new curriculum. As described earlier, there is a great diversity of schools in South Africa, from well resourced to completely under-resourced, with teachers who are well-qualified and others who are under-qualified, so therefore it should be recognized that not all schools have the capacity to implement a given innovation to the same extent and within the same timeframe. Table 3.2 provides a means of gauging those factors that must be present in a school for successful implementation of a new curriculum (Rogan \& Grayson, 2003). 
Table 3.2 Levels of factors that form the capacity to support innovation within a school

\begin{tabular}{|c|c|c|c|c|}
\hline Level & Physical Resources & Teacher Factors & Learner Factors & School Ecology and Management \\
\hline 1 & $\begin{array}{l}\text { Basic buildings - class- } \\
\text { rooms and one office, but } \\
\text { in poor condition. } \\
\text { Toilets available } \\
\text { Some textbooks - not } \\
\text { enough for all }\end{array}$ & $\begin{array}{l}\text { Teacher is under-qualified } \\
\text { for position, but does have } \\
\text { a professional qualifica- } \\
\text { tion }\end{array}$ & $\begin{array}{l}\text { Learners have some } \\
\text { proficiency in language of } \\
\text { instruction, but several } \\
\text { grades below grade level }\end{array}$ & $\begin{array}{l}\text { Management: A timetable, class lists and other } \\
\text { routines are in evidence. } \\
\text { The presence of the principal is felt in the school at } \\
\text { least half the time, and staff meetings are held at } \\
\text { times } \\
\text { Ecology: School functions i.e. teaching and learning } \\
\text { occur most of the time, albeit erratically. } \\
\text { School is secure and access is denied to } \\
\text { unauthorized personnel }\end{array}$ \\
\hline 2 & $\begin{array}{l}\text { Adequate basic buildings } \\
\text { in good condition } \\
\text { Suitable furniture - } \\
\text { adequate and in good } \\
\text { condition } \\
\text { Electricity in at least one } \\
\text { room } \\
\text { Textbooks for all } \\
\text { Some apparatus for } \\
\text { science }\end{array}$ & $\begin{array}{l}\text { Teacher has the minimum } \\
\text { qualification for position } \\
\text { Teacher attends school/ } \\
\text { classes regularly } \\
\text { Teacher is motivated and } \\
\text { diligent. Enjoys his/her } \\
\text { work } \\
\text { Teacher participates in } \\
\text { professional development } \\
\text { activities } \\
\text { Teacher has a good rela- } \\
\text { tionship with and treat- } \\
\text { ment of learners }\end{array}$ & $\begin{array}{l}\text { Learners are reasonably } \\
\text { proficient in language of } \\
\text { instruction } \\
\text { Learners attend school on } \\
\text { a regular basis } \\
\text { Learners are well nou- } \\
\text { rished } \\
\text { Learners are given } \\
\text { adequate time away from } \\
\text { home responsibilities to } \\
\text { do school work }\end{array}$ & $\begin{array}{l}\text { Management: Principal is present at school most of } \\
\text { the time and is in regular contact with his/her staff } \\
\text { Timetable properly implemented } \\
\text { Extramural activities are organized in such a way } \\
\text { that they rarely interfere with scheduled classes } \\
\text { Teachers/learners who shirk their duties or display } \\
\text { deviant behaviour are held accountable } \\
\text { Ecology: Responsibility for making the school } \\
\text { function is shared by management, teachers and } \\
\text { learners to a limited extent. } \\
\text { A School Governing Body is in existence. } \\
\text { Schools functions all the time i.e. learning and } \\
\text { teaching always take place as scheduled }\end{array}$ \\
\hline
\end{tabular}


Table 3.2 Levels of factors that form the capacity to support innovation within a school (Continued)

\begin{tabular}{|c|c|c|c|c|}
\hline Level & Physical Resources & Teacher Factors & Learner Factors & School Ecology and Management \\
\hline 3 & $\begin{array}{l}\text { Good buildings, with } \\
\text { enough classrooms and a } \\
\text { science room } \\
\text { Electricity in all rooms } \\
\text { Running water } \\
\text { Textbooks for all pupils } \\
\text { and teachers } \\
\text { Sufficient science } \\
\text { apparatus } \\
\text { Secure premises } \\
\text { Well kept grounds }\end{array}$ & $\begin{array}{l}\text { Teacher is qualified for } \\
\text { position and has a sound } \\
\text { understanding of subject } \\
\text { matter } \\
\text { Teacher is an active } \\
\text { participant in professional } \\
\text { development activities } \\
\text { Conscientious attendance } \\
\text { of class by teacher } \\
\text { Teacher makes an extra } \\
\text { effort to improve teaching }\end{array}$ & $\begin{array}{l}\text { Learners are proficient in } \\
\text { language of instruction } \\
\text { Learners have access to } \\
\text { quiet, safe place to study } \\
\text { Learners come from a } \\
\text { supportive home } \\
\text { environment } \\
\text { Learners can afford text- } \\
\text { books and extra lessons } \\
\text { Parents show interest in } \\
\text { their children's progress }\end{array}$ & $\begin{array}{l}\text { Management: Principal takes strong leadership role, } \\
\text { is very visible during schools hours } \\
\text { Teachers and learners play an active role in school } \\
\text { management } \\
\text { Ecology: Everyone in the school is committed to } \\
\text { making it work } \\
\text { Parents play active role in School Governing Bodies } \\
\text { and in supporting the school in general }\end{array}$ \\
\hline 4 & $\begin{array}{l}\text { Excellent buildings } \\
\text { One or more well equip- } \\
\text { ped science laboratory } \\
\text { Library or resource centre } \\
\text { Adequate curriculum } \\
\text { materials other than } \\
\text { textbooks } \\
\text { Good teaching and } \\
\text { learning resources (e.g. } \\
\text { computers, models) } \\
\text { Attractive grounds } \\
\text { Good copying facilities }\end{array}$ & $\begin{array}{l}\text { Teacher is over-qualified } \\
\text { for position and has an } \\
\text { excellent knowledge of } \\
\text { content matter } \\
\text { Teacher has an extra- } \\
\text { ordinary commitment to } \\
\text { teaching } \\
\text { Teacher shows willingness } \\
\text { to change, improvise and } \\
\text { collaborate, and has a } \\
\text { vision of innovation } \\
\text { Teacher shows local and } \\
\text { national leadership in } \\
\text { professional development } \\
\text { activities }\end{array}$ & $\begin{array}{l}\text { Learners are fluent in the } \\
\text { language of instruction } \\
\text { Learners take responsi- } \\
\text { bility for their own } \\
\text { learning } \\
\text { Learners are willing to try } \\
\text { new kinds of learning }\end{array}$ & $\begin{array}{l}\text { Ecology: There is a shared vision } \\
\text { The school plans for, supports and monitors change } \\
\text { Collaboration of all stakeholders is encouraged and } \\
\text { practiced } \\
\text { Management: There is a visionary, but participatory, } \\
\text { leadership at the school }\end{array}$ \\
\hline
\end{tabular}


The four sub-constructs that contribute to the Capacity to Innovate are especially relevant in the South African context for most schools. In each case, an increase in level indicates a greater capacity to innovate. Unlike the Profile of Implementation, the levels here do represent a progression, and the ultimate and idealistic goal for a school would be to achieve level four on all four factors.

- Physical Resources are a pivotal influence on implementation, anywhere in the world. Poor resources and conditions can limit the performance of even the best of teachers and undermine learners' efforts to focus on learning. The ideal status of resources for a school for science and mathematics education would be good buildings in well-kept surroundings, well-equipped science laboratories and library, adequate resource materials and support services such as photocopying facilities.

- Teacher factors, particularly their background, training, confidence and commitment to the vocation, impact on how well they can adapt to change in the classroom. As a result of apartheid education many South African teachers lack solid subject matter knowledge. As they grapple with trying to improve their own knowledge, teachers' energies might not be available for investment in new curricula. Ideally teachers should be well-qualified for their positions with excellent content knowledge. There should be an enthusiasm for innovation and a commitment to teaching and willingness to change.

- Learner factors affect the learners' ability to focus on their own schoolwork. Many learners come from a home environment where there is no place for them to do homework, and no one to support and help them in their studies. Family and culture related commitments might mean an absence from school for significant periods of time. In South Africa, most learners are not fluent in the language of instruction. Ideally, learners should be competent in their languages of instruction, take responsibility for their own learning and be willing to learn in different ways.

- School ecology and management are two separate but intertwined factors, particularly in the South African context. If the school is in disarray and dysfunctional it is obvious that no innovation can or will be implemented. In such cases, the first step in implementing innovation would be to restore order and discipline. Ideally in terms of school ecology, there ought to be a shared vision in a collaborative atmosphere. In terms of management, there should be a visionary, and also collaborative school leadership. 
The relative contribution of these four factors to the construct Capacity to Innovate is likely to be dynamic, changing over time depending both on the level of the school and the stage of implementation. Malcolm, Keane, Hoolo, Kgaka and Owens (2000) found that some high schools with very similar physical facilities produced strikingly different matriculation examination results. Their study suggests that teacher and school management factors may well be the largest contributors to the Capacity to Innovate construct, at least at the early stages of implementation. The 'schools of excellence' that they studied were characterised by a visible ethos of learning and working together towards a shared vision. The key players were the teachers and principal who created the conditions conducive to learning, and the students and parents who then bought into and perpetuated them.

\subsection{OUTSIDE INFLUENCES}

Support from outside the school environment includes that which comes from the Education Department, Non-Governmental Organisations (NGO's) or any other organisation that interacts with a school in order to implement change. The profile of Outside Influences is intended to describe the kinds of actions undertaken by these outside organisations, as well as the ways in which they manifest their intentions. Table 3.3 presents a likely profile of the types and levels

of support and pressure that various organisations might bring to bear on a school in South Africa in order to facilitate change (Rogan \& Grayson, 2004). 
Table 3.3 Levels of outside influences

\begin{tabular}{|c|c|c|c|c|c|}
\hline \multirow[t]{3}{*}{ Level } & \multicolumn{3}{|c|}{ Types of encouragement and support } & \multirow{3}{*}{$\begin{array}{l}\text { Dominant change force } \\
\text { evoked by agency }\end{array}$} & \multirow{3}{*}{$\begin{array}{l}\text { Monitoring mechanisms } \\
\text { and accountability }\end{array}$} \\
\hline & \multicolumn{2}{|c|}{ Material Support } & Non-material Support & & \\
\hline & $\begin{array}{l}\text { Physical Resources } \\
\text { Categories of resources: } \\
\text { Buildings, apparatus, curri- } \\
\text { culum materials (print and } \\
\text { electronic), computers, etc. }\end{array}$ & $\begin{array}{l}\text { Direct support to } \\
\text { learners }\end{array}$ & Design of Professional Development & & \\
\hline 1 & $\begin{array}{l}\text { Provision supplements } \\
\text { what exists, but not } \\
\text { enough to support the } \\
\text { intended changes. } \\
\text { Provision is in one } \\
\text { category only. }\end{array}$ & $\begin{array}{l}\text { Provision of basic } \\
\text { needs, such as } \\
\text { lunches and places } \\
\text { to study. }\end{array}$ & $\begin{array}{l}\text { Information on policy and } \\
\text { expected changes are presented } \\
\text { to school based personnel. } \\
\text { Typical mode is short, one shot } \\
\text { workshop. }\end{array}$ & $\begin{array}{l}\text { Bureaucratic: } \\
\text { Change is brought about } \\
\text { by top down directives } \\
\text { to bring about change. }\end{array}$ & $\begin{array}{l}\text { Inspections by } \\
\text { authorities are } \\
\text { undertaken }\end{array}$ \\
\hline 2 & $\begin{array}{l}\text { Provision completely } \\
\text { covers what is required to } \\
\text { effect the intended change } \\
\text { in one category, or partly } \\
\text { sufficient in two } \\
\text { categories. }\end{array}$ & $\begin{array}{l}\text { Basic academic } \\
\text { needs are catered } \\
\text { for in the form of } \\
\text { extra lessons. }\end{array}$ & $\begin{array}{l}\text { Examples of 'new' practices as } \\
\text { suggested by the policies are } \\
\text { presented to school based } \\
\text { personnel, who are given an } \\
\text { opportunity to engage in these } \\
\text { practices in a simulated situation. } \\
\text { Typical mode is a series of short } \\
\text { workshops lasting for one year. }\end{array}$ & $\begin{array}{l}\text { Charismatic: } \\
\text { Change is brought about } \\
\text { by top down inspiration } \\
\text { and encouragement }\end{array}$ & $\begin{array}{l}\text { Inspections are } \\
\text { undertaken in } \\
\text { collaboration with } \\
\text { school-based personnel. }\end{array}$ \\
\hline
\end{tabular}


Table 3.3 Levels of outside influences (Continued)

\begin{tabular}{|c|c|c|c|c|c|}
\hline \multirow[t]{3}{*}{ Level } & \multicolumn{3}{|c|}{ Types of encouragement and support } & \multirow{3}{*}{$\begin{array}{l}\text { Dominant change force } \\
\text { evoked by agency }\end{array}$} & \multirow{3}{*}{$\begin{array}{l}\text { Monitoring mechanisms } \\
\text { and accountability }\end{array}$} \\
\hline & \multicolumn{2}{|c|}{ Material Support } & \multirow{2}{*}{$\begin{array}{l}\text { Non-material Support } \\
\text { Design of Professional Development }\end{array}$} & & \\
\hline & $\begin{array}{l}\text { Physical Resources } \\
\text { Categories of resources: } \\
\text { Buildings, apparatus, curri- } \\
\text { culum materials (print and } \\
\text { electronic), computers, etc. }\end{array}$ & $\begin{array}{l}\text { Direct support to } \\
\text { learners }\end{array}$ & & & \\
\hline 3 & $\begin{array}{l}\text { Provision completely } \\
\text { covers what is required to } \\
\text { effect the intended change } \\
\text { in two categories, or partly } \\
\text { sufficient in three } \\
\text { categories. }\end{array}$ & $\begin{array}{l}\text { Enriched academic } \\
\text { needs are catered } \\
\text { for in the form of } \\
\text { field trips and other } \\
\text { enrichment type } \\
\text { activities. }\end{array}$ & $\begin{array}{l}\text { Professional development is } \\
\text { designed by school based } \\
\text { personnel depending on which } \\
\text { new practices they wish to } \\
\text { implement, and implemented } \\
\text { using both inside and outside } \\
\text { support. } \\
\text { Typical mode consists of both } \\
\text { external and school-based INSET } \\
\text { for two to three years. }\end{array}$ & $\begin{array}{l}\text { Professional: } \\
\text { Change is brought about } \\
\text { by encouraging role } \\
\text { players to embrace codes } \\
\text { of conduct and standards } \\
\text { of teaching and learning }\end{array}$ & $\begin{array}{l}\text { School-based personnel } \\
\text { monitor own progress, } \\
\text { but report to authorities }\end{array}$ \\
\hline 4 & $\begin{array}{l}\text { Provision completely } \\
\text { covers what is required to } \\
\text { effect the intended change } \\
\text { in three categories, or } \\
\text { covers two categories and } \\
\text { is partly sufficient in all } \\
\text { four categories. }\end{array}$ & $\begin{array}{l}\text { Complete academic } \\
\text { and personal } \\
\text { support is } \\
\text { provided, usually in } \\
\text { the form of } \\
\text { bursaries. }\end{array}$ & $\begin{array}{l}\text { Communities of practice take full } \\
\text { responsibility for their own } \\
\text { continued professional growth, } \\
\text { and for school governance and } \\
\text { curriculum implementation, } \\
\text { calling on outside support as } \\
\text { appropriate. } \\
\text { Typical mode consists of ongoing } \\
\text { school-based and directed } \\
\text { professional INSET. }\end{array}$ & $\begin{array}{l}\text { Learning Community: } \\
\text { Change is brought about } \\
\text { by developing } \\
\text { communities that } \\
\text { develop shared values } \\
\text { and goals regarding } \\
\text { educational practice and } \\
\text { a commitment to put } \\
\text { these into practice. }\end{array}$ & $\begin{array}{l}\text { All monitoring is } \\
\text { undertaken by school- } \\
\text { based personnel. }\end{array}$ \\
\hline
\end{tabular}


- Types of encouragement and support deals with two forms of support to schools;

- Material support is divided into two categories, the provision of physical resources such as buildings, curriculum materials, computers and apparatus on the one hand, and direct support to learners on the other, which might include such things as school lunch programmes and safe, quiet places to study outside of class time. Both of these kinds of support can be provided at various levels.

- Non-material support is most commonly provided in the form of professional development, and is perhaps the most visible and obvious way in which outside agencies attempt to bring about changes in schools. This dimension has two sub-themes. The first is the underlying purpose or focus of the professional development. At level one, the INSET concentrates mainly on providing information about expected changes emanating from the policy and about what teachers are expected to do as a result in their classrooms. Moving through the levels, there is an increasing emphasis on professional development, which is focused on implementation of change rather than just providing information, and a greater sense of teacher ownership of the process. The second sub-theme has to do with the extent and duration of the support. The levels here range from a one-shot workshop to continuous, school-based development.

- Dominant change force evoked by agency indicates the kinds of forces that an organisation chooses to use as leverage in bringing about change. At the lower levels the forces are more in the form of pressure and at the higher levels are more supportive of a system that the teachers and their hierarchy have bought into and have taken ownership of. Pressure, as opposed to support, is often applied by means of various forms of monitoring and accountability.

At level 1 change is brought about through directives filtered from the top, down. At level 2 the change is more encouraged rather than instructed, but is also administered from the top, down. At level 3, the teaching hierarchy is expected to do more than merely accept direction from above to implement change. There is an expectation that parties concerned show some responsibility from within themselves towards the changes by embracing codes of conduct and standards of teaching and learning. Ideally, as indicated by Level 4 , those people involved in change implementation should form a community that have 
a common vision regarding the values and goals and educational practice and a commitment to attain and maintain these values and goals.

- Monitoring mechanisms and accountability indicates the extent to which the monitoring is external, as opposed to internal. At level one, the pressure may come from the Department of Education in the form of edicts to innovate. External pressure is largely political in nature, and is likely to kick start the process and to achieve at least a token compliance. However, it is the internal pressures, those that evoke 'learning community forces', that are most likely to result in meaningful change, and are described at level 4.

\subsection{HOW THE CONSTRUCTS WERE USED TO FRAME THE STUDY}

The three constructs and their sub-constructs of the Rogan-Grayson framework provide a systematic deconstruction of factors that may affect curriculum implementation. The structure and orderliness provided by the framework made it a very appropriate vehicle to investigate the situation in Mpumalanga in order to develop an insight into the status of curriculum changes taking place there. In the design of the teacher questionnaires for the survey and the interview questions and observation schedules for the case studies, interrogative items were formulated for each sub-construct (see chapter four). The data were then used to develop a picture of the different factors involved with curriculum implementation in Mpumalanga as well as to investigate the relationships between the constructs and sub-constructs. The interactions between various sub-constructs may shed new light on curriculum implementation in the South African context.

The Rogan-Grayson framework was developed with knowledge of curriculum change gleaned from the literature as well as personal experience of the authors about the South African context. It has been touted as a tool that can be used to measure different facets of curriculum change that can be adapted to various contexts. At least three points can be considered as limitations or potential weaknesses in the framework.

1. It is not possible to predict every variable that might influence curriculum change in every context. The framework includes as sub-constructs the most general variables that can be considered applicable in most contexts. It might 
happen that in a particular context, a variable with a significant impact might be omitted. This weakness might be overcome by applying contextual knowledge to adapting the framework prior to using it as a research tool in different contexts.

2. The framework alone cannot predict the proportion of impact various subconstructs might have on curriculum change. Does the provision of learning materials contribute as much to curriculum uptake as teacher training for example? The danger of using such a framework without careful consideration of weighting of factors could be the assumption that all factors in curriculum change provide equal impact, or, if different levels of impact can be shown in one context, that the levels are consistent for different contexts.

3. The elaboration of some of the constructs is debatable. The tables provide what could be interpreted as very specific practices that need to be exhibited before the practices can be 'scored' in their progress. There could, however, be other practices that might indicate the same level. It must be stressed that the tables were intended as a guide to increasing levels of performance and not as a strict measuring tool. However, some of the examples given for levels of practice might be unrealistic. For example, the level four practice under Monitoring Mechanisms and Accountability states that all monitoring is undertaken by school-based personnel. The level description implies that outside checks and balances are not required for monitoring. However, a school-based monitoring system would have to evaluate itself against an outside standard in order to maintain some degree of quality assurance.

The framework was developed within the South African context by South African researchers. Also, the explanatory tables expanding on the framework were developed within the context of science and mathematics education in South Africa. These advantages made the framework ideal for use in this study as further contextual knowledge was not required to alter the framework to fit. No other variables beyond the sub-constructs provided in the framework were thought necessary to add to the framework in its original form.

The application of structural equation modelling in this study would provide an idea of the contribution each of the sub-constructs made to the overall changes that were taking place in the uptake of the new curriculum in Mpumalanga. For 
the South African context, this could enrich the framework by providing contributing magnitudes to the different sub-constructs. The application of structural equation modelling is covered in Chapter Seven of this dissertation. The strengths and the weaknesses of the framework will be elucidated by the structural equation modelling process and will be elaborated on in the concluding chapter. 


\section{CHAPTER 4 \\ Research methods}

The data for the MSSI research project were collected in two ways. Firstly teacher questionnaires were designed for a large scale survey (4.1). The development of the questionnaire is discussed in this chapter (4.1.1) along with how the data were collected (4.1.2). How the data was analysed is covered in section 4.1.3. The second data collection method comprised of case studies (4.2). The development of the case study materials and protocol, the data gathering and data analysis are explained in sections 4.2.1 to 4.2.3. The data gathered from the 2003 questionnaire are used as the main source of data for the study. The data from the case studies of 2002 are used to explain, support or substantiate the findings of the questionnaire study. Data for both studies are reported together in Chapter 6.

\subsection{THE TEACHER QUESTIONNAIRE}

For the main part of this study, a teacher questionnaire was developed throughout the duration of the first phase of the MSSI and was administered in various forms in 2001, 2002 and 2003. The study that this dissertation will be reporting on makes use of the data collected from the 2003 questionnaire. The 2003 questionnaire had the dual advantage of being administered in the final year of the first phase of the MSSI when the sample was at its largest, and the questionnaire had been refined through several revisions to be in line with the Rogan-Grayson framework, improving its content validity. This part of the study was quantitative and endeavoured to gather a large amount of data about the sub-constructs in the Rogan-Grayson framework (2004).

\subsubsection{Development of the questionnaire}

The questionnaire study was aimed at a large number of respondents while in other related studies within the MSSI, more qualitative approaches were taken. In January 2001, science education experts and post-graduate students from the 
Universities of Naruto, Hiroshima, Wisconsin, Twente, Pretoria and South Africa met for two days in Pretoria to design the research for the year. One of the decisions was to collect data using a questionnaire. Suggestions for questions were given and further work on the questionnaire was done via e-mail. In retrospect the key steps Stone (1993) sets out for questionnaire design were followed.

- In the discussions between the academics it was decided what data would be required.

- Items for inclusion were selected from existing questionnaires and new items were formulated specific to the sections of the questionnaire.

- Special deliberation was given to the wording as it would be mostly second language English speakers filling in the questionnaire.

- The layout and presentation was designed in consultation with the Statistics Department of Pretoria University. It had to be consistent throughout for ease of reading as well as later data capture.

- The coding was determined by the Statistics Department.

- The first draft was sent out to all the academics for feedback after the questionnaire was finally put together.

- It was piloted in 10 schools in one district in Mpumalanga in March 2001.

- Evaluation of the pilot informed modifications that were made to the instrument. The questionnaire was sent out to teachers in the remaining 9 districts in Mpumalanga in May 2001.

The first questionnaire was over-ambitious in respect of the amount of information it was intended to gather. It was a bulky 41 page document consisting of five parts.

- The first part requested purely demographic information such as age, gender, qualifications and experience of the teacher. This part was kept in the next two versions of the questionnaire.

- Part 2 asked questions about curriculum implementation issues at the microlevel.

- Part 3 questioned issues pertaining to school-based factors that could influence implementation.

- Part 4 interrogated factors that might influence implementation that come from outside of the school environment.

- The last part (5), was aimed at the assessing the level of understanding of mathematics and science concepts that the teachers had. 
Many of the questions in the first version of the questionnaire were intended to form a baseline on which to develop further research or interventions. All the questions were closed for ease of data capture and because of the high number of respondents and consequently numerous possible answers open questions would elicit.

In January 2002, a second conference was held at the University of Pretoria, which included personnel of the Mpumalanga Department of Education (MDE), the Curriculum Implementers and researchers from Japan, USA, Netherlands and South Africa. The results of the 2001 survey were presented and discussed. Ways of improving the questionnaires were also put forward for discussion. In 2002, the questionnaire was altered to shorten it and questions that previously proved problematic were removed. Also, certain questions were not required as those questions in the 2001 research were merely to establish a snapshot of attitudes, so a linear study was not required of them. By this stage the RoganGrayson theoretical framework was in press. The changes made to the 2002 teacher questionnaire improved it in general, and brought it partially into line with the theoretical framework.

In January 2003, a third conference was held at the University of Pretoria. The results of the 2002 teacher and learner surveys were discussed. Based on the feedback from the analyses, and the discussion at the conference, some minor changes were made for the 2003 version of the teacher questionnaire. The 2003 questionnaire was brought completely into alignment with the Rogan-Grayson framework. In addition, some of the wording from the Revised Assessment Standards from C2005 was adopted in the description of the Level 4 practices.

In contrast to the 41 pages of the 2001 questionnaire, the 2003 questionnaire was 11 pages long. Part one inquired about demographic data, as in the 2001 questionnaire. The following three parts corresponded to the three constructs in the Rogan-Grayson framework and the items within them addressed the subconstructs. Table 4.1 illustrates the alignment between the items in the questionnaire and the framework for the 2003 questionnaire. The questionnaire is available as Appendix 1. 
Table 4.1 Alignment between items in the 2003 questionnaire and sub-constructs from the Rogan and Grayson framework

\begin{tabular}{|c|c|c|}
\hline Construct & Sub-construct & $\begin{array}{l}\text { Item interrogating the sub- } \\
\text { construct }\end{array}$ \\
\hline \multirow[t]{4}{*}{$\begin{array}{l}\text { Profile of } \\
\text { implementation }\end{array}$} & Classroom interaction & $\begin{array}{l}\text { Level } 1 \text { - V39, V40, V43, V44 } \\
\text { Level } 2 \text { - V41, V46, V47, V49 } \\
\text { Level } 3 \text { - V38, V48 } \\
\text { Level } 4 \text { - V42, V49 }\end{array}$ \\
\hline & Assessment practices & $\begin{array}{l}\text { Level } 1 \text { - V55 } \\
\text { Level } 2 \text { - V50, V51 } \\
\text { Level } 3 \text { - V52, V56 } \\
\text { Level } 4 \text { - V53, V54 }\end{array}$ \\
\hline & Science and maths in society & $\begin{array}{l}\text { Level } 1 \text { - V58 } \\
\text { Level } 2 \text { - V57 } \\
\text { Level } 3 \text { - V60 } \\
\text { Level } 4 \text { - V59 }\end{array}$ \\
\hline & Science practical work & $\begin{array}{l}\text { Level } 1 \text { - V67 } \\
\text { Level } 2 \text { - V62, V64, V66 } \\
\text { Level } 3 \text { - V63, V68 } \\
\text { Level } 4 \text { - V61, V65 }\end{array}$ \\
\hline \multirow[t]{4}{*}{$\begin{array}{l}\text { Capacity to } \\
\text { innovate }\end{array}$} & Teacher factors & $\begin{array}{l}\text { Level } 1 \text { - V69, V70, V77, V78 } \\
\text { Level } 2 \text { - } \\
\text { Level } 3 \text { - V71, V72, V74, V75, } \\
\text { V76 } \\
\text { Level } 4 \text { - V73 } \\
\text { Cross check V139 and V140 }\end{array}$ \\
\hline & Learner factors & V117 - V129 \\
\hline & Physical resources & $\begin{array}{l}\text { V90 -V112 and } \\
\text { V113 - V116 }\end{array}$ \\
\hline & School ecology and management & V79 - V89 \\
\hline \multirow{4}{*}{$\begin{array}{l}\text { Outside } \\
\text { influences }\end{array}$} & Professional development & V139 - V153 \\
\hline & Monitoring and Accountability & V154 - V159 \\
\hline & Influencing (motivating factors) & V130 - V138 \\
\hline & Physical resources & $\begin{array}{l}\text { V90 -V112 and } \\
\text { V113 - V116 }\end{array}$ \\
\hline
\end{tabular}

Appendix 4 shows a table which illustrates the development of the questionnaire over the three years pertaining to the constructs and sub-constructs from the framework. It indicates some questions that were maintained throughout the 3year course of the larger quantitative study. 


\subsubsection{Validity and reliability of the questionnaire}

A commendable aim of rigorous research is the solution of valuable and fundamental research questions through the use of techniques that are both reliable and valid (Hammersley, 1987; Verma \& Mallick 1999). A valid probe is one that tests what is supposed to be tested (Bell, 1999; Verma \& Mallick, 1999; White \& Gunstone, 1992). A reliable probe is one that will produce similar results on different occasions under constant conditions (Bell, 1999; Verma \& Mallick, 1999).

Validity

In 2001 a team of science education experts met to design the questionnaire as part of the larger MSSI study. The questionnaire underwent further development over the following two years. In 2001, when the first version of the questionnaire was designed, the Rogan-Grayson framework was already in its initial stages of development. The three constructs, Profile of Implementation, Capacity to Innovate and Outside Influences had already been conceptualized. The team, in designing the questionnaire, sought ways to measure these constructs. The aim from the beginning of the questionnaire design process was to achieve construct validity. The reviewing of probes by the team, as suggested by Bell (1999), was used to ensure that a degree of construct validity was attained. The expert team judged each probe for the degree to which they matched the questionnaire objective (i.e. did the probes measure the constructs?), for ambiguity and for correct questioning technique (Bell, 1999). The entire expert input was taken into account before finalizing the instrument.

The 2001 science and maths education expert panel reconvened in 2002 and focused on bringing the 2001 questionnaire more into line with the framework. By now the framework was complete and detailed profiles for the levels within the constructs were defined. The 2001 questionnaire analysis demonstrated that the questionnaire measured the constructs it was designed to measure (Rogan et al, 2002). In being able to claim through statistical analysis of the 2001 questionnaire that the probes tested the constructs as intended, the 2002 questionnaire had acquired construct validity (Trochim, 2006).

As the study progressed into 2003, items were kept that specifically gathered information about the three constructs from the Rogan-Grayson framework and others were discarded. By 2003, wording from the framework was now introduced into the questionnaire and examples were given to illustrate the intent of the items. 
The continued revision of the instrument from 2001 to 2003 was intended to continually improve its construct validity (Rogan \& Aldous, 2004).

\section{Reliability}

Reliability is the extent to which the measurements of a questionnaire remain consistent over repeated applications of the questionnaire. Some appropriate items for the three constructs from the 2002 questionnaire were subjected to a factor analysis. Factors were identified (see appendix 2) and those items that loaded high on these factors were selected for the 2003 questionnaire. The factor analysis of 2002 and the use of items loading high within these factors in the 2003 questionnaire indicate reliability of the 2003 questionnaire.

\subsubsection{Gathering the data}

The 2003 questionnaire was distributed to teachers in May 2003. Two curriculum implementers per district (one for mathematics and one for general science) hand-delivered the questionnaires to the schools, collected them from the schools when complete and returned them to the researchers by July of the same year. Hand-delivery and collection ensured a higher response rate than would have been expected through a system where questionnaires would have been posted out and returned by mail. The sample in each district was selected by the curriculum implementers (or in one case the district manager), who were asked to meet certain criteria of representativeness. These criteria included a mix of rural and urban schools as well as schools where the majority of the learners were either all black (previously Department of Education and Training (DET) schools), or all white (Previously Transvaal Education Department (TED) schools.) However, the aim of the study was to get a picture of the average school, so more rural schools were included rather than urban schools and more DET schools rather than TED schools were included to make the sample representative. Chapter 5 describes the teacher sample in more detail.

Curriculum implementers were asked to involve 14 - 20 schools from each of the nine Mpumalanga districts (dependant upon the total number of schools in the district) in the questionnaire study. At the time, Districts 8 and 9 did not yet have curriculum implementers appointed, so these districts could not be included in the study. It was requested that two mathematics teachers and two general science teachers from each school who taught Grade 7 - 9 complete the questionnaire. In some cases, teachers might have taught both mathematics and 
general science resulting in fewer than 4 responses per school. In other cases, more maths and/or science teachers volunteered to complete the questionnaire and their data was included. Table 4.2 shows the number of schools and teachers per district that completed the questionnaire. The data were coded by an assistant employed by the Centre for Science Education at the University of Pretoria and captured by the data capture centre of the University of Pretoria.

Table 4.2 Number of schools and teachers (per school district) that participated in the questionnaire study

\begin{tabular}{|ccc|} 
School District & Number of schools & Number of teachers \\
\hline 1 & 21 & 63 \\
2 & 10 & 31 \\
3 & 20 & 47 \\
4 & 6 & 20 \\
5 & 18 & 48 \\
6 & 16 & 30 \\
7 & 26 & 84 \\
Total & 117 & 323 \\
\hline
\end{tabular}

\subsubsection{Analysis of the data}

Simple statistics, such as means, were derived using the SAS (Statistical Analysis System) package. These are reported in Chapter Six. More complex statistical analyses were derived using SPSS (Statistical Package for the Social Sciences). These data are reported in Chapter Seven.

\subsection{THE CASE STUDIES}

Survey techniques can yield good data about a large number of schools and teachers. However, there are sometimes gaps in the information they supply that can be filled by closer observations acquired by case studies. Case studies can also be used to substantiate the findings of surveys which are based on selfreported data (Babbie, 2000). Case studies are a way of obtaining in-depth understanding of the features and dynamics of one particular case from amongst many. It uses data collection methods such as observation, interviews and document collection (Miles \& Huberman, 2002). 


\subsubsection{The case study approach in Mpumalanga}

In January 2002 the results of the 2001 survey were reported and discussed at a specially arranged conference attended by JICA officials, personnel from the Mpumalanga Department of Education (mostly curriculum implementers) and researchers. The lack of case study type data was highlighted, and consequently the decision was made to undertake a series of case studies. One-week duration, in-depth studies of implementation of C2005 in twelve Mpumalanga schools were conducted during May and June 2002.

Although the case studies were carried out a year before the questionnaire based study reported on in this thesis, the schools for both studies are representative of the province as a whole. Not all the case study schools were included in the questionnaire study, but no direct comparisons within schools of both studies have been carried out for this study. The aim was not to generalise the findings to all the schools, but to gain an in-depth understanding of the processes and problems associated with the implementation of C2005 in the maths and science learning areas. The research on the case study data has been published elsewhere (Rogan \& Aldous, 2005) and is used in this study to support, illustrate, problematize and discuss the findings of the survey where appropriate.

The Mpumalanga Department of Education, upon request, provided the research team with a suggested list of 20 schools in which to undertake the case studies. The list contained both rural and urban schools as well as well resourced and poorly resourced schools. This list was used to select eight of the schools. The selection of these eight schools was based on their proximity to Pretoria, where most of the researchers involved in the cases studies were based. The remaining four schools were not on the Department's list, but were selected by the researchers in such a way as to make the final selection as representative of the province as possible. All of the major types of schools found in the province were represented in the final selection such as rural and urban schools and ex-DET and ex-TED schools. The selection comprised schools in 7 of the province's 10 school districts.

Each case study was undertaken by a different researcher. The author and research-supervisor each conducted one study, while seven of the others were undertaken by curriculum implementers, who took leave from their work to undertake the study, and who did not do the research in their own district. Two of the curriculum implementers already had doctorates, while others were enrolled 
in masters or doctoral programs. Two masters and one doctoral student, who were not curriculum implementers, undertook a case study each. A total of twelve case studies were undertaken. However, two case studies were rejected for analysis owing to lack of completion, leaving only 10 case studies in the investigation.

\subsubsection{Development of the case study materials}

Because a different researcher was to conduct each case study, all involved met in April 2002 in order to formulate a common research strategy. At this meeting, semi-structured interview questions that were structured around the three constructs of the Rogan-Grayson framework, were designed for students, teachers and the school principal. Common protocols were developed for lesson observation and video-taping of general science and mathematics lessons. A list of the kinds of documentation (mission statements, resources, and so on) to be collected was developed. A guide was developed which included all this information to give each researcher an indication of the kind of data that was to be collected and how the collection should occur. It assumed that the case study field worker would spend one week in the school involved in the case study. The field worker was expected to be at the school during the entire school day for the entire week, and to become as much part of the school as possible. This guide also provided the framework and guidelines on how the case study should be written up. See Appendix 5 for the complete Case Study field guide.

\subsubsection{Gatering the data}

Each of the researchers spent one full week in a school, and in some instances continued into a second week. Data on the three constructs were gathered in three ways viz. observation, interviews and from documents.

\section{Observations}

The observation sheet provided was used to record what happened in the classrooms. At the end of each day, lessons were written out in full in a narrative form. Using the Profile, researchers were asked to indicate what aspects of the Profile were observed, and to characterise the lessons in terms of the levels of its dimensions.

Permission to video-tape lessons was to be sought from the teacher. If granted, the video-tape would be used later for in depth study. 


\section{Interviews}

An interview schedule was provided for the principal, teachers and learners. The interview is best characterised as being "semi-structured". The questions on the schedules provided the structure. However, at the discretion of the researcher, some questions could be omitted if the answer was known, say by observation. It was suggested that additional questions and probing follow up questions were asked. Answers to the questions were to be recorded in writing during the interview. With the permission of the interviewee, the interview was to be tape recorded.

It was suggested that the principal be interviewed towards the end of the week, as there might have been issues that arose during the study that required his clarification.

Each of the grade 8 and 9 science and maths teachers was to be interviewed once. This interview was to occur after the teacher had been observed, as again there might be follow up questions based on the observation.

Learners were to be interviewed in a "focus group" of about five. Teachers were asked to select the five, unless the researcher had an idea, after observing the learners in the classroom, of those whom he or she would like to interview. A representative group with respect to gender and ability was to be formed. The researcher was to ensure that he or she would be able to communicate with the learners - especially in the case where the researcher could not use the learners' home language.

At the discretion of the researcher, other interviews could be conducted as the opportunity arose, e.g. with a school board member. It was requested of the researcher to write up the interviews in full at the end of each day, using notes and the tape recording.

\section{Documents}

Copies of documents such as a mission statement, school improvement plan, and staff development plan were to be collected from each school. Other useful documents such as lesson plans, worksheets, assignments and tests were also to be collected where possible. These documents would be referred to during the analysis of the data to substantiate or refute any of the case study findings. 
The final case reports

At the end of each case study, the researcher wrote up a summary report, according to an agreed upon format given in the field guide which later facilitated cross-comparison. The reports were given to the schools for comment before being lodged with the research leaders. Finally all reports, interviews, observation sheets, video-tapes and documents were handed to the authors for further analysis. An example of a school report is given in Appendix 5.

\subsubsection{Analysing the data}

The case study reports from all the researchers were gathered and analysed by Rogan and Aldous (2005). These same results will be referred to in this dissertation. Two of the twelve school's data were incomplete and therefore were excluded from further analysis. For the observations for each of the constructs the authors rated each school against the levels given in the tables of the framework with numeric values indicating a level of practice. A value of 1 would indicate the lowest level within the framework and a value of 4 would indicate the highest level, i.e. complete implementation of C2005 with respect to that construct. The values allocated to each school with respect to the sub-constructs of the Profile of Implementation can be seen in Appendix 5. The ratings for the individual schools were added together and an average calculated to give an indication of the situation with respect to C2005 implementation in Mpumalanga. These ratings were later to be compared with the scores for the same subconstructs in the survey data.

\subsection{SUMMARY}

Both quantitative and qualitative approaches were taken in the overall study of the implementation of C2005 in the Mpumalanga province. A questionnaire was developed over a period of three years that was in line with the Rogan-Grayson Framework as well as the ideals of C2005. The case studies were carried out in a single study and were also designed to be in line with the Rogan-Grayson Framework as well as the ideals of C2005. These data are presented and discussed in Chapter 6. However, the questionnaire also yielded demographic data that was descriptive of the sample of the teachers from Mpumalanga. These data are reported in Chapter 5. 


\section{CHAPTER 5 \\ Description of the samples for the questionnaire study and the case studies}

An understanding of the context and sample characteristics is important in understanding the relationships between constructs that will be discussed in chapters six and seven. This chapter reports the demographic data from the respondents of the questionnaire (5.1). The age and gender profile of the teachers is given followed by their teaching experience in different subjects at different grade levels. A description of the schools included in the case studies is also given (5.2).

\subsection{DESCRIPTION OF THE TEACHER SAMPLE IN THE QUESTIONNAIRE STUDY}

The research was geared towards the analysis of C2005 implementation in natural science and mathematics in Grades 8 and 9 specifically and so only questionnaires that specifically indicated that teachers taught these subjects were retained for analysis. Of the 323 questionnaires returned, data from only 228 were retained. 95 respondents did not indicate that they taught Grades 8 and 9 mathematics or natural science, so their questionnaires were discarded.

Table 5.1 shows the numbers and percentages of the teachers who taught science and/or mathematics in Grades 8 and $9.12 \%$ of the teachers taught both mathematics and science in Grade 8 and $9.48 \%$ of the teachers taught mathematics only and 39\% natural science only in the same grades.

Table 5.1 Science and mathematics teachers in Grades 8 and $9(n=228)$

\begin{tabular}{lcc} 
& Number of teachers & Percentage \\
\hline Natural Science only teachers & 90 & 39 \\
\hline Mathematics only teachers & 109 & 49 \\
Natural Science and Mathematics teachers & 29 & 12 \\
Total & 228 & 100
\end{tabular}


Part 1 of the questionnaire was aimed at gathering information about the teachers' age, gender and teaching experience. There were also two questions that probed the availability of mathematics and natural science textbooks. However, these questions relate to resources under the Capacity factor and will be reported in Chapter 6.

Table 5.2 shows that more than half the teachers were in their thirties. Just under a quarter of them were in their forties. Teachers in the more senior age groups were fewer in number with the lowest frequency of teachers in the over fifties age group. There is a very low frequency of teachers in their twenties.

Table 5.2 Age of teachers in age groups $(n=225)$

\begin{tabular}{|l|c|}
\hline Age & Percentage \\
\hline Under 25 & 4 \\
\hline $25-29$ & 14 \\
\hline $30-39$ & 54 \\
\hline $40-49$ & 23 \\
\hline 50 and over & 4 \\
\hline
\end{tabular}

Table 5.3 shows that there are more male teachers than female teachers, with a $42 \%$ female: $58 \%$ male split.

Table 5.3 Gender of teachers (in percentages) for mathematics and natural science $(n=221)$

\begin{tabular}{|c|cccc} 
& \multicolumn{3}{c}{ Subjects taught by teachers } & Total \\
& Natural Science & Mathematics & $\begin{array}{c}\text { Natural science } \\
\text { and mathematics }\end{array}$ & \\
Female & 45 & 39 & 39 & 42 \\
Male & 55 & 61 & 61 & 58
\end{tabular}

The gender gap in natural science teaching is smaller than that in mathematics.

Table 5.4 indicates the years of experience in teaching the teachers in the sample had. The columns indicate years of teaching in general, those taught at the current school and years teaching different subjects. Half the teachers $(24 \%+$ $26 \%$ ) had 10 years or less experience in teaching. Looking at the subjects targeted in this study, Mathematics and Natural Science, $67 \%$ and $89 \%$ respectively of the teachers had 10 years or less experience in teaching these subjects. 
Table 5.4 Percentages of teachers with various categories of years of experience for subjects related to natural science and mathematics teaching (V8 - V16)

\begin{tabular}{|c|c|c|c|c|c|c|c|c|}
\hline $\begin{array}{l}\text { Number } \\
\text { of years } \\
\text { of } \\
\text { teaching }\end{array}$ & $\begin{array}{c}\text { In } \\
\text { general } \\
n=180\end{array}$ & $\begin{array}{c}\text { At } \\
\text { current } \\
\text { school } \\
n=183\end{array}$ & Maths & $\begin{array}{c}\begin{array}{c}\text { Physical } \\
\text { science }\end{array} \\
n=100\end{array}$ & Geography & Agriculture & $\begin{array}{c}\text { Biology } \\
n=40\end{array}$ & $\begin{array}{l}\begin{array}{r}\text { Natural } \\
\text { science }\end{array} \\
n=130\end{array}$ \\
\hline $1-5$ & 24 & 40 & 35 & 63 & 68 & 77 & 55 & 78 \\
\hline $6-10$ & 26 & 32 & 32 & 27 & 18 & 9 & 35 & 11 \\
\hline $11-15$ & 33 & 22 & 24 & 8 & 14 & 9 & 7 & 8 \\
\hline $16-20$ & 12 & 5 & 6 & 2 & & 5 & 3 & 1 \\
\hline $21+\mathrm{yrs}$ & 5 & 1 & 3 & & & & & 2 \\
\hline
\end{tabular}

Items V17 to V33 in the questionnaire asked for which of the grades teachers were teaching mathematics, natural science, physical science and biology that year? Natural Science is a broad subject taught from Grade 7 to Grade 9 that incorporates biology. Physical Science is taught from grades 10 to 12 and includes physics and chemistry. Teachers were requested to indicate all the grades to which they were teaching these subjects. The results are indicated in Table 5.5.

Table 5.5 Percentage of teachers teaching mathematics, natural science, physical science and biology in different Grades (V17 - V33)

\begin{tabular}{|lcccc|} 
& Mathematics & Natural science & $\begin{array}{c}\text { Physical } \\
\text { science }\end{array}$ & Biology \\
\hline Grade 5 & 3 & & & \\
\hline Grade 6 & 7 & & & \\
\hline Grade 7 & 34 & 29 & & 3 \\
\hline Grade 8 & 37 & 32 & 12 & 3 \\
\hline Grade 9 & 19 & 16 & 12 & 13 \\
\hline Grade 10 & 14 & & 3 & \\
\hline Grade 11 & 14 & & & \\
\hline Grade 12 & 7 & & & \\
\hline
\end{tabular}

The study focussed on teachers teaching grades 8 and $9.37 \%$ in grade 8 and 19\% in grade 9 of the teachers in the sample were mathematics teachers in the years appropriate to the study. Many teachers taught higher than Grade 9, and very few taught grades lower than grade 7 . In the Mpumalanga province there are some "Middle Schools" which cater for the three grades in the senior phase of the General Education and Training (GET) band i.e. grades 7, 8 and 9. High schools that would be fed by these schools begin at Grade 10. Other schools cater for 
Grades 1 to 7 with high schools beginning at Grade 8 level. This accounts for the similarity in percentages between Grade 7 and 8 teachers and the difference between Grade 8 and 9 teachers.

\subsection{DESCRIPTION OF THE SCHOOLS OBSERVED DURING THE CASE STUDIES}

Case studies were carried out in 12 different schools although only 10 are reported as previously explained. Each school was investigated by a different researcher and their reports retained for further analysis. Names of the schools were replaced by alphabetical letters. The 10 schools were diverse in nature with some having unique situations that set them apart of the others. They were divided into four groups based on their geography, history and funding.

The first group was rural schools. These schools were previously administered by Homeland Governments and are mostly under-resourced. The school on private property was partly funded by the government and the private concern who owned the property. The interest from the private funder ensured better resources for such schools. Township schools occurred in suburbs that were laid out under the Apartheid government for black residents. These schools were previously under the DET administration and were less resourced than the white schools. The ex-model C school was the most privileged of white government schools. Although still owned by the government, ex-model C schools were allowed to raise further funds to provide more resources, including more teachers to maintain a lower learner:teacher ratio.

\subsubsection{Rural schools}

Schools A and B were middle schools closely situated to the big Gauteng cities. School J was a high school situated in the more rural eastern parts of the Mpumalanga province. Because of their differences, Schools A and B are discussed together and School $\mathrm{J}$ is discussed below separately.

Schools A and B were rural schools situated within one hours drive from the Gauteng metropolis in the west of the Mpumalanga province. In many cases, people from the community lived in the Gauteng cities and returned to the area only on weekends or at the end of the month. The area was fairly densely 
populated with a number of small villages and open communal farmlands in between. The communities around the schools were poor, with agriculture and small business providing the main sources of income.

Both schools had been under the same homeland administration under the previous government which had a different structure to school grades than other South African schools. Three different types of schools were provided for schooling from Grades 1 to 12. Grades 1 to 6 were catered for in primary schools, Grades 7 to 9 in middle schools and Grades 10 to 12 in high schools. Both schools A and B were Middle Schools. In school A there were 418 learners, 10 teachers and a principal who also taught some classes in addition to his administration load. School B had 392 learners and 15 staff members, including the headmaster. In both schools there was an active School Governing Body.

The typical architecture of a middle school consisted of two parallel rows of classrooms with an administration block built at right angles at one end to create the effect of a courtyard. In School A there were eight classrooms with the staffroom converted to make a ninth classroom. There was an administration block with seven small offices. The buildings were well built but had been vandalised. There were no ceilings. School B had also been previously vandalised, but the Department of Education had recently provided improvements such as tiling of floors, repairing of ceilings and painting of walls. An extra row of classrooms had been built so that each grade in the school had its own row of classrooms.

The school sites were approximately 1 hectare in size. Water was provided allowing enough clean water for personal use as well as for limited gardening activity. The school grounds in general were well kept and clean.

Both schools were fenced and in the case of School A the fencing was financed by the Governing Body. There were lockable gates. At School A, the only secure room on the premises was the principal's office which has a security door with burglar proofing. All valuables such as the photocopier and science equipment and chemicals were stored in this office. The School Governing Body for School B paid for burglar bars for all doors and windows.

In School A, classrooms had enough desks for learners but the furniture needed to be repaired or replaced, as a lot of the desks and chairs were broken. The 
classrooms were small and therefore overcrowded. The school had no library and textbooks were stored in the administration building in a storeroom cum office. Text books were in general adequately supplied but the department failed to provide enough books for grade 8 learners. There was no laboratory and very little science equipment. Practicals were seldom done. There were no computers, but there was a copier machine situated in the principal's office.

School B had marginally better facilities. Desks and chairs were arranged to facilitate group work. The Grade 8 row of classrooms was partitioned inside by solid metal roller shutters in order to allow the block to be used as a hall at times when they are rolled up. The problem with this arrangement, however, was that noise carried from one classroom to the next. A library was being put together at the end of this block at the time the research was undertaken. At the time the library contained only textbooks, old and new. The end room of the $9^{\text {th }}$ grade row was being converted into a laboratory. However, at the time, all science practical equipment were unopened and the room was used by the Head of Department as her office.

In School A, the principal's office was the only office with electricity. Electricity had been supplied to classrooms previously, but due to vandalism and theft, it no longer functioned. With the revamping of School B, electricity had been restored to all classrooms. Outside lights were put on the buildings of School A recently. School B had lights that came on automatically at night for security purposes. School A had no telephones. The entire district the school was in did not have telephone lines as there was a border dispute between the Mpumalanga and Limpopo provinces about who was responsible for supplying the phone lines.

School J was situated in the east of Mpumalanga. It was a high school catering for grades 8 through 12 with 907 learners and 25 staff members. There were three rows of buildings, one occupied by offices a small library, a staff room and a photocopy room, and the others consisted of classrooms. In addition there was a recently built laboratory containing stored science practical equipment. An office for the technology teacher is accommodated in this building too.

The buildings were in a poor state of repair, mainly due to vandalism, with ceilings, windows and toilet facilities broken. One tap provided water for general use. The school was fenced completely. The electrical infrastructure had been 
vandalised, leaving classrooms without electricity. There were not enough desks and chairs for all the learners and those that there were, were in need of replacement or repair.

\subsubsection{School on private property}

School G was collaboratively managed by both the Department of Education and a private mining company near one of the Mpumalanga cities. It was a primary school which catered for learners from Grade R (reception year) to Grade 9. There was a staff of 17 teachers, a secretary and a cleaner serving the needs of 490 learners. All buildings were in an excellent state of repair. Besides classrooms, there was a principal's office, a staff room, a technical drawing studio, a computer room and a library. There was no science laboratory, but there was a storeroom for the science practical equipment that was used in the classrooms. The school grounds are well maintained and contain several sporting facilities.

\subsubsection{Township schools}

The majority of schools in Mpumalanga are situated in township areas. Schools C, D, E, F and I were all located within townships. In South Africa, the term 'township' refers to a high population density urban and suburban mix of homes and small businesses inhabited by predominantly black people. The description of a township was given by the researcher for School $\mathrm{F}$ and this description typifies township areas:

"Different houses ranging from own construction (plan), four rooms, bond houses, are found in the township. Almost all streets are having tarred roads. Running water is not a problem as the river is crossing around the township. Many services are found in the township, two filling stations (garages) stadium which host big soccer matches for top clubs in Premier Soccer League (PSL) - capacity of stadium is plus minus 30000 seater, big and small shops, hair-dressing and some small business around the school which sell food for school children - apples, bananas, chips, fish, avocados and famous dust chicken. Many people found employment in the township - municipality, police, nurses, teachers. The majority work in the city and travel daily; the city is plus or minus $30 \mathrm{~km}$ distant." 
Township schools are generally bigger than rural schools with schools with Schools C, D, E and F having had enrolments exceeding 1200 learners. Schools C, $\mathrm{E}, \mathrm{F}$ and I had learner/teacher ratios of 37, 33, 35 and 36 respectively. School D had much larger class sizes with 55 learners in each Grade 8 class and 45 learners in each grade 9 class. In township schools, additional support staff was sometimes employed such as grounds staff. The grounds man at school D was responsible for gate control as well as grounds maintenance. School F employed two men to maintain to grounds.

In general, the condition of the township school buildings is better than that of the rural schools. Buildings are better maintained and there is less vandalism. However, there are exceptions. School I has classrooms with broken locks, broken ceilings and electrical wiring removed. School $\mathrm{C}$ had broken windows in just one block of classrooms, but these were due to be repaired within a short time. At school $\mathrm{F}$ the classrooms were wired for electricity, but electricity was only delivered in the administration blocks. In school D, vandalism was beginning to show itself, so parents raised funds to fence the classrooms and offices within the school boundary.

Rural schools in many cases have their grounds plundered by livestock which wander through if there are no adequate fences. In contrast, the township schools have better grounds facilities, with sports facilities in some schools. Some schools employ groundsmen to keep the grounds clean and in order. In school D, there were vegetable gardens from which learners were permitted to supply their homes. Sometimes the produce from these gardens was sold to the community in order to raise funds. In School $\mathrm{F}$ the natural science teachers and their classes have also planted a small vegetable garden.

Classroom furniture is at best adequate. In Schools C, F and I there is no desk or chair for the teacher. School $E$ was best off with enough desks and chairs for teachers and learners alike. In school C, the furniture is in a good state of repair, but there are not enough desks and chairs for all the learners. In School D, the researcher described the classroom furniture as "...old and inadequate for learners."

Science laboratories in most schools pose a conundrum. Many schools have had laboratories and lab equipment sponsors, yet teachers still complain about 
inadequacies. It appears however, that science teachers need to be coached into using the lab facilities. School $\mathrm{C}$ had both a science and a biology laboratory, neither of them put to use by the teachers. The science lab was used as an extra classroom while the biology lab was used as a staff room by some of the teachers. School E had 5 laboratories, three for science and two for biology. Teachers at this school reported that they were inadequately set-up, however, on inspection, the researcher discovered many boxes of brand new science equipment that had not been unpacked for use. School I also has one laboratory each for science and biology that have been well resourced except for a supply of water and electricity. These laboratories are used mainly by the higher grade teachers.

Water and electricity supplies are inconsistent across the Mpumalanga schools. Some schools have no infrastructure or supply at all, others have only borehole water, others have all the infrastructure but no supply. Schools A, D, E and F all had adequate water and electricity supply. School I, however, only had electricity and running water in the administration block.

\subsubsection{Ex-model C school}

In 1991, the then Minister of Education, Mr Piet Clase, announced that the separate systems of education for race groups were to be replaced by a single system (McKenzie, 1993). What had previously been whites-only schools were allowed to opt and vote for 'community' status. Three 'Models for Schooling' were offered which aimed at giving the community a greater say in the management and direction of the school. These three models were:

Model A - private schools established after the closure of state schools

Model B - state schools that wished to change their admissions policy Model C - state aided schools.

The majority of the schools selected the Model C option. Model C was significant, because for the first time in apartheid SA, state white schools enrolled non-whites.

School K was situated in the suburbs of a small country town east of the Gauteng metropolis. Organized agriculture, mining areas and small industry surrounded the town, providing employment to many of the inhabitants, while others commuted daily to the East Rand and Johannesburg or the Pretoria region. 
School K was situated on the northeastern edge of the town in a suburban area. School K had 608 learners and 25 teaching staff, of whom 3 had Governing Body posts, 18 had permanent posts and 4 had temporary posts, the latter two groups being paid by the Government.

The school buildings were typical of those provided to traditionally white schools prior to 1994, with double story classroom, specialized kitchen and laboratory buildings linked by corridors, and a school hall. They were modern and functional. The Administration Block was a separate single story building but was closely connected to the classroom buildings. It contained the staff room, staff kitchen, strong room, Headmaster's offices, deputy Head's offices, reception and staff ablution facilities. All parts of the buildings were well maintained and services (water and electricity) were in good working order. A security fence surrounded the school and an alarm system had been installed which was activated when the last person left the premises, and deactivated in the morning when the first staff member arrived at the school.

A park-like atmosphere had been created in the front of the school with several trees, evergreen shrubs and lawn. Behind the school was an open, paved courtyard. Near the entrance to the school was a treed, paved parking area for teachers. Sports facilities of the highest order were provided. There were several sporting facilities. There were grandstands overlooking the open field with floodlights that had been provided by the parents. The school grounds were impeccably clean and well manicured and showed pride in the school.

The classrooms and laboratory were well appointed, clean and had a warm atmosphere. There were enough desks and chairs for learners as well as the teachers, with extra cupboards for the teachers. In one class the desks were arranged to accommodate group work. The desks in the laboratory were high worktables that were fixed to the floor, so they could not be rearranged to accommodate group work all that easily, but they were excellent for practical work. Some of the school furniture was old and in need of repair, but it was not yet bad enough that the furniture needed replacing. The HOD's all had offices of their own close to their classrooms. 


\subsection{SUMMARY}

The case studies provided a means for gathering data on the settings of different schools within the Mpumalanga province. The majority of learners are educated in township schools. There are schools in the rural areas, which in many cases are more poorly resourced than their township counterparts. There are ex-model C schools in the province that have a more privileged setting directly as a result of past inequities in education. Where the private sector is involved in education, there is extra financial backing. The extra money available helps to keep the school well run and maintained.

Information about the teaching staff of the schools was gleaned from the questionnaire study. Data were retained from 228 questionnaires. More than half of the respondents were male and more than half again were in the age bracket 30-39. The majority of teachers had 10 years or less experience teaching various subjects. The 10-year mark divided the sample of teachers in half with regards years experience in teaching in general. For grades 8 and 9, teachers taught either mathematics, or mathematics and science. There were no teachers who taught only natural science.

The context and the sample characteristics expanded upon above, provide a background for understanding and appreciating the survey data and the relationships between the constructs and sub-constructs. The survey data are presented in the next chapter, Chapter 6, and the relationships between the constructs and sub-constructs are presented in Chapter 7. 


\section{CHAPTER 6 \\ Measures of the three constructs}

In this chapter an overall view of the constructs, namely Implementation of Curriculum, Capacity of Schools to Innovate and Outside Influences, as well as their sub-constructs in schools in Mpumalanga is presented. This is the purpose of the first research focus. This chapter also paves the way to explore possible relationships between the constructs and sub-constructs in the next chapter, Chapter 7, which addresses the second research focus. The questionnaire was designed to gather data on the sub-constructs and constructs of the Rogan-Grayson framework. Data from each of the constructs are reported below along with the data from the same constructs gathered during the case studies. Data for the Profile of Implementation are presented in 6.1. In 6.2 the capacity of schools to implement the new curriculum (the construct Capacity to Innovate) is reported. Those factors from outside the school (the construct Outside Influences) that affect implementation of innovation are presented in 6.3. Section 6.4 provides a summary of the content of this chapter.

\subsection{DATA ON PROFILE OF IMPLEMENTATION}

The construct "Implementation of Curriculum" has four sub-constructs for which data were sought. These include Classroom Interaction, Assessment Practice, Science and Mathematics in Society and Science Practical Work. Each of these sub-constructs was measured using a profile that shows four steps towards achieving complete C2005 implementation. The items asked in the questionnaire were designed to gain an understanding of the extent to which the ideals of the C2005 general science and mathematics curricula were being practiced in the classroom. A Likert scale was used for each of the sub-constructs and where possible, each item was phrased to include examples for clarity. 


\subsubsection{Classroom interaction}

In the questionnaire a list of practices was given derived from the Profile of Implementation. The practices occurred at different levels in the profile. However, the investigation took place shortly after C2005 was implemented; so many more probes tested for practices at levels 1 and 2, in order to ascertain whether there was a movement out of the starting blocks towards an incremental implementation of the C2005 ideals. The aim of this set of questions was to determine which of these practices teachers use and how frequently they might use them without being aware of the level of practice. After each statement they were asked to circle one of the numbers which have the meaning as indicated. Table 6.1 shows the percentages of teachers who selected from 1 to 5 .

Table 6.1 Frequency percentages of classroom interaction practices, indicating level of implementation

\begin{tabular}{|c|c|c|c|c|c|c|c|c|}
\hline & & Level & $\mathbf{N}$ & 1 & 2 & 3 & 4 & 5 \\
\hline V38 & $\begin{array}{l}\text { Learners make their own notes on } \\
\text { topics that they learn through } \\
\text { doing hands-on learning activities. }\end{array}$ & 2 & 204 & 26.04 & 19.79 & 15.28 & 19.79 & 19.10 \\
\hline V39 & $\begin{array}{l}\text { Teacher engages class in question } \\
\text { and answers sessions. }\end{array}$ & 1 & 220 & 0.98 & 2.93 & 4.23 & 17.26 & 74.59 \\
\hline V40 & $\begin{array}{l}\text { Teacher presents information to the } \\
\text { class using written material (i.e. } \\
\text { notes or textbook). }\end{array}$ & 1 & 213 & 2.65 & 4.64 & 6.62 & 26.82 & 59.27 \\
\hline V41 & $\begin{array}{l}\text { Teacher provides information that } \\
\text { comes from sources other than the } \\
\text { school level textbooks (e.g. maga- } \\
\text { zines, newspapers, journals, ency- } \\
\text { clopaedias). }\end{array}$ & 2 & 221 & 6.21 & 18.30 & 26.80 & 28.10 & 20.59 \\
\hline V42 & $\begin{array}{l}\text { With help from the teacher, lear- } \\
\text { ners take responsibility for their } \\
\text { learning by working on long-term } \\
\text { projects, investigations or reports. } \\
\text { (An example of such a project } \\
\text { would be to identify a problem e.g. } \\
\text { lack of food, and develop a } \\
\text { solution such as a school vegetable } \\
\text { garden. Learning takes place as the } \\
\text { project is undertaken). }\end{array}$ & 3 & 216 & 19.27 & 52.49 & 15.28 & 7.64 & 5.32 \\
\hline V43 & $\begin{array}{l}\text { Learners work individually (e.g. } \\
\text { copy notes from board or text book } \\
\text { or do exercises from the text book } \\
\text { or worksheets). }\end{array}$ & 1 & 219 & 4.87 & 6.49 & 7.47 & 38.64 & 42.53 \\
\hline
\end{tabular}


Table 6.1 Frequency percentages of classroom interaction practices, indicating level of implementation (Continued)

\begin{tabular}{|c|c|c|c|c|c|c|c|c|}
\hline & & Level & $\mathbf{N}$ & 1 & 2 & 3 & 4 & 5 \\
\hline V44 & $\begin{array}{l}\text { Teacher presents information to the } \\
\text { class using a lecture. }\end{array}$ & 1 & 221 & 25.16 & 10.00 & 10.65 & 30.00 & 24.19 \\
\hline V45 & $\begin{array}{l}\text { Learners work in groups on open } \\
\text { problem solving activities that are } \\
\text { geared towards the group's needs } \\
\text { and interests. Different groups } \\
\text { might work on different problems. } \\
\text { (An open problem solving activity } \\
\text { is one in which there is more than } \\
\text { one answer and more than one } \\
\text { way of solving it). }\end{array}$ & 4 & 219 & 2.92 & 12.34 & 14.94 & 36.04 & 33.77 \\
\hline V46 & $\begin{array}{l}\text { Learners us additional (to text } \\
\text { book) sources of information in } \\
\text { compiling notes. }\end{array}$ & 2 & 216 & 27.00 & 19.00 & 13.00 & 20.33 & 20.67 \\
\hline V47 & $\begin{array}{l}\text { Learners work in groups in which } \\
\text { they interact with one another on a } \\
\text { given task. }\end{array}$ & 2 & 221 & 0.32 & 5.18 & 14.24 & 30.74 & 49.51 \\
\hline V48 & $\begin{array}{l}\text { Teacher mentions how concepts } \\
\text { have been derived by referring to } \\
\text { the works of prominent } \\
\text { mathematicians or scientists in } \\
\text { history. }\end{array}$ & 2 & 216 & 9.21 & 15.46 & 14.14 & 29.28 & 31.91 \\
\hline V49 & $\begin{array}{l}\text { Learners bring items to school on } \\
\text { their own initiative to enrich } \\
\text { lessons. }\end{array}$ & 2 & 220 & 34.74 & 24.68 & 13.96 & 17.21 & 9.42 \\
\hline
\end{tabular}

Note: $1=$ Never, $2=$ Once a term, $3=$ Up to three times a term, $4=$ Once a week, $5=$ Every day.

According to the survey data, most level 1 practices are exercised on a daily or weekly basis. If the total percentage frequency for level 1 and level 2 everyday practices are averaged, then level 1 practices score $50.15 \%$ and level 2 practices score $25.2 \%$. The difference between levels 1 and 2 is expected, because level 1 practices reflect old practice while level 2 shows a movement towards the new curriculum. Any change from the old is expected to be more tentative in the beginning. There is a spread of use of Level 2 practices among the teachers. Some Level 2 practices, (indicated by V47 and V48) are carried out daily or weekly by more than half the teachers. Over $40 \%$ but fewer than $50 \%$ of the teachers and learners provide information that comes from sources other than school textbooks to augment learning materials on a weekly or daily basis. Less than $40 \%$ of the learners make their own notes on topics that they learn through doing 
hands-on learning activities or bring items to school for enrichment on their own initiative on a daily or weekly basis. In fact these latter practices occur three times a term at most for the majority of learners.

Only one level 3 practice was itemised and has a percentage frequency (as an everyday practice) of $5.32 \%$ and weekly practice of $7.64 \%$. Once again there is an anticipated difference, showing a lower frequency than levels 1 and 2 practices. However, the practice is reported to be carried out at least once a term by most teachers. Unexpectedly, the level 4 practice itemised provided an unrealistically high frequency of daily practice of $33.77 \%$. It is unclear whether the teachers misrepresented themselves because they were unsure of the meaning of the term 'open ended' which is the defining term in this probe for level 4 practices. Teachers may have read more emphasis into the element of group work in the probe. It was observed in the case studies that much group work is done in the classrooms, but not necessarily, if ever, with open ended tasks.

The observations made during the case studies show more conservative scores than the self-reported data of the questionnaires. From the case studies it appears that most schools are still operating as they were before the curriculum change, with teachers in schools A, B, C, D, F and I all performing at level 1 for classroom interaction.

Schools E and J were found to be performing at a level lower than level 1, meaning that the observations made were of practices that were of a poor standard. In School $\mathrm{E}$ a lesson was observed that confused the learners completely as the teacher tried to implement his notion of OBE. The learners were asked to brainstorm around a topic for 20 minutes and then give feedback. After the feedback, they were sent back into a brainstorming session for twenty minutes in order to search for a single synonym. While the brainstorming sessions were in progress a different task was introduced. What was absent from this lesson was adequate material for the learners to research during brainstorming as well as planning what the outcomes of that lesson were to be.

Schools $\mathrm{G}$ and $\mathrm{K}$ were seen to be practicing at levels 2 and 2,5 respectively, indicating that only these two schools had made observable progress in incorporating higher order classroom interaction practices. School $\mathrm{K}$ was the exmodel C school with good facilities and well qualified teachers. The teachers 
expressed confusion about the interrelationships between OBE, C2005 and Provincial and Departmental policy. However, in the classrooms, the teachers observed applied the principles behind learner-centredness, with group activity and science practical work occurring at a regular frequency.

In some cases it was observed that old practices were viewed as C2005 practices or that the teachers had already been teaching using C2005 practices under the old curriculum. In School A, the researcher noted that all the teachers had received departmental $\mathrm{OBE}$ training and all lessons were planned according to the format required; however, content was still a problem. Teachers still used old text books and fell back on old teaching methods. In this school teachers had placed learners in groups and group discussion featured in many of the observed lessons. Although the groupwork was not always fruitful, the learners were free to talk, discuss, argue, assist each other and question the teacher, a step towards learner-centredness. However, another example (School K) was observed when learners were requested to show calculations on the board during a mathematics lesson. The act of allowing the child to write on the blackboard and show his work was construed by the teacher as being learner-centred. The intention of learner-centred education was completely missed.

\subsubsection{Assessment practice}

A list of assessment practices was given that were derived from the levels in the Profile for Assessment. Teachers were asked which of these practices they used and how frequently they use them. After each assessment practice they were asked to circle one of the following numbers which had the meaning as indicated. The results of these items are given in Table 6.2 on the next page.

There was only one Level 1 practice itemised which summed up the assessment carried out before C2005. Most teachers reported to using pen and paper tests for recall of learned material for up to 3 times a term. It appears from the data that more level 2 practices were being exercised in assessment than any of the other levels, indicating that a move has been made to move towards higher levels of assessment. 
Table 6.2 Frequency percentages of assessment practices

\begin{tabular}{|c|c|c|c|c|c|c|c|c|}
\hline & & Level & $\mathbf{N}$ & 1 & 2 & 3 & 4 & 5 \\
\hline V50 & $\begin{array}{l}\text { Some of the questions in the test are } \\
\text { based on practical work the learners } \\
\text { have previously carried out. }\end{array}$ & 2 & 223 & 4.82 & 3.54 & 22.19 & 19.29 & 50.16 \\
\hline V51 & $\begin{array}{l}\text { Written tests with questions that } \\
\text { require comprehension, application } \\
\text { or analysis are given. }\end{array}$ & 2 & 223 & 0.96 & 2.56 & 23.40 & 28.85 & 44.23 \\
\hline V52 & $\begin{array}{l}\text { Written tests include questions based } \\
\text { on seen or unseen "guided } \\
\text { discovery" type activities. }\end{array}$ & 3 & 221 & 10.36 & 6.47 & 35.60 & 20.39 & 27.18 \\
\hline V53 & $\begin{array}{l}\text { Performance based assignments of } \\
\text { best work. (Performance based } \\
\text { assessment means the assessment of } \\
\text { some kind of performance or action). }\end{array}$ & 4 & 215 & 12.00 & 10.67 & 38.33 & 21.33 & 17.67 \\
\hline V54 & $\begin{array}{l}\text { Performance based portfolios of best } \\
\text { work. }\end{array}$ & 4 & 216 & 6.95 & 11.59 & 43.71 & 16.89 & 20.86 \\
\hline V55 & $\begin{array}{l}\text { Written tests with questions that } \\
\text { assess mainly recall of facts learned in } \\
\text { the topic are given. }\end{array}$ & 1 & 216 & 5.41 & 2.03 & 23.31 & 30.41 & 38.85 \\
\hline V56 & $\begin{array}{l}\text { Assessment of activities other than } \\
\text { tests e.g. reports on activities } \\
\text { undertaken, creation of posters and } \\
\text { improvised apparatus or models, } \\
\text { projects etc. }\end{array}$ & 3 & 223 & 10.26 & 14.10 & 42.63 & 16.03 & 16.99 \\
\hline
\end{tabular}

Note: $1=$ Never, $2=$ Once a year, $3=$ Once a term, $4=\mathrm{Up}$ to three times a term, $5=$ Once for each sub-topic covered in class.

The frequencies reported for level 3 and 4 practices were lower than those for level 1 and 2, but still over-optimistic. There has been much in-service training on assessment practice to promote implementation of C2005, with the result that teachers are aware of a hierarchy of good practice in assessment. However, the case study observations indicated that despite the training, assessment practice were closer to level 1 with some level 2 practices being included occasionally. Being self-reported data, frequency reports for levels 3 and 4 are likely to be inflated.

The case studies showed that in the area of assessment, at least half the schools are still using pen and pencil rote learning tests only. There are, however, some schools that are clearly making the effort to move away from pure rote learning type assessment to an approach that tests thinking and what learners can do with 
the knowledge acquired in the lessons. These include Schools B, C, F, G, J and K. In School B, pen and pencil tests included questions of higher order thinking with very few questions requiring recall. In this school assessment included projects, class-work, homework, written report and oral presentations. School C made an attempt at distinguishing between 'formative' and 'summative' assessment by having weekly tests covering that weeks' work and term tests which covered all the work of the term. However, much progress must still be made before there will be enough confidence to broaden the assessment to be more continuous and project based.

\subsubsection{Science and mathematics in society}

A list of ways that science and mathematics can be linked to societal issues was given in the questionnaire. One item was provided to gauge each level of practice. Teachers were asked to try to estimate the amount of time spent on societal issues devoted to the practices given. After each statement teachers were asked to circle one of the following numbers which have the meaning as indicated. Table 6.3 shows the data from these items.

The Level 1 practice, as expected was that most frequently used by teachers, in fact almost $61 \%$ of the teachers said they used this practice on a daily basis. Level 3 and level 4 practices were more rarely exercised. $74 \%$ of the teachers said that they use the level 4 practice either once a term or never and for the level 3 practice $60 \%$ said they exercised that practice either once a term or never. The Level 2 practice was more frequently practiced than levels 3 and 4 but the gap between frequency of the level 1 practice and level 2 practice was larger than between level 2 and 3 practices, indicating that in most cases, very little effort has been made to include science and society in natural science and mathematics teaching at a level beyond Level 1.

The case study observations indicate that most schools have not made much progress with regards teaching the relationship between science and society. Teaching the relationship between science and society is problematic for the teachers in South Africa. The teachers' own education in science did not include linking science and society and they have few resources at their disposal showing them this link. Teachers have been taught science as theory throughout their training and have for years taught it the way they learned it, so the ability to see 
scientific application in everyday life has not been developed. Teachers rely heavily on resource materials for teaching and currently there are not many resources that explicitly show the relationship between science and society in an everyday manner. Most schools (C, D, E, F, G and J) did not show any attempt to include science in society issues in their lessons. School B was seen to make some effort without quite reaching a minimum standard and schools $\mathrm{A}$, I and $\mathrm{K}$ all showed the minimum standard, operating at level 1.

Table 6.3 Frequency percentages of use of ways of including science and mathematics in societal issues

\begin{tabular}{|c|c|c|c|c|c|c|c|c|}
\hline & & Level & $\mathbf{N}$ & 1 & 2 & 3 & 4 & 5 \\
\hline V57 & $\begin{array}{l}\text { Lessons are based on a } \\
\text { specific problem or issue } \\
\text { faced by the local commu- } \\
\text { nity. (For example, access } \\
\text { to water might be a pro- } \\
\text { blem around which } \\
\text { lessons are based). }\end{array}$ & 2 & 222 & 19.81 & 37.34 & 17.86 & 16.23 & 8.77 \\
\hline V58 & $\begin{array}{l}\text { Teacher uses examples and } \\
\text { applications from every- } \\
\text { day life to illustrate scien- } \\
\text { tific concepts or mathe- } \\
\text { matics procedures }\end{array}$ & 1 & 223 & 0.97 & 7.10 & 11.94 & 19.35 & 60.65 \\
\hline V59 & $\begin{array}{l}\text { Learners actively under- } \\
\text { take a project in their local } \\
\text { community in which they } \\
\text { apply science and mathe- } \\
\text { matics to tackle a specific } \\
\text { problem or meet a specific } \\
\text { need. (An example might } \\
\text { be on growing a new type } \\
\text { of crop (to that area) to } \\
\text { increase the income of the } \\
\text { community). }\end{array}$ & 4 & 221 & 34.85 & 38.76 & 10.10 & 8.79 & 7.49 \\
\hline V60 & $\begin{array}{l}\text { Learners actively investi- } \\
\text { gate the application of } \\
\text { science and mathematics } \\
\text { in their own environment. } \\
\text { (Examples are an audit of } \\
\text { energy use and a traffic } \\
\text { volume survey). }\end{array}$ & 3 & 223 & 24.19 & 36.13 & 20.32 & 10.00 & 9.35 \\
\hline
\end{tabular}

Note: $1=$ Never, 2 = Once a term, $3=\mathrm{Up}$ to three times a term, $4=$ Once a week, $5=$ Every day. 


\subsubsection{Science practical work}

Only natural science teachers were asked to complete the items for this section. A list of types of practical work was given. Teachers were asked to gauge of the time spent on practical work, how often they had used each of these practices in their classrooms over the previous month. After each statement they were to circle one of the following numbers which have the meaning as indicated.

Table 6.4 Frequency percentages of types of practical work carried out

\begin{tabular}{|c|c|c|c|c|c|c|c|c|}
\hline & & Level & $\mathbf{N}$ & 1 & 2 & 3 & 4 & 5 \\
\hline V61 & $\begin{array}{l}\text { Learners design their own "open" } \\
\text { investigations. They reflect on the } \\
\text { quality of the design and collected } \\
\text { data and are able to modify to } \\
\text { improve the quality of the design. }\end{array}$ & 4 & 145 & 39.71 & 35.89 & 13.88 & 7.18 & 3.35 \\
\hline V62 & $\begin{array}{l}\text { Learners fill in worksheets that are } \\
\text { given with a practical task. }\end{array}$ & 2 & 145 & 11.43 & 26.67 & 29.52 & 22.86 & 9.52 \\
\hline V63 & $\begin{array}{l}\text { Learners perform practical work in } \\
\text { groups using apparatus. They are } \\
\text { given a problem or question and } \\
\text { they then design their own experi- } \\
\text { ment and ensure that their data is } \\
\text { accurate. }\end{array}$ & 4 & 142 & 23.15 & 24.14 & 23.15 & 22.17 & 7.39 \\
\hline V64 & $\begin{array}{l}\text { Learners use data from demonstra- } \\
\text { tions to construct their own graphs } \\
\text { and tables. }\end{array}$ & 2 & 143 & 10.63 & 28.02 & 24.64 & 24.15 & 12.56 \\
\hline V65 & $\begin{array}{l}\text { Learners interpret data in support } \\
\text { of competing theories or } \\
\text { explanations. }\end{array}$ & 4 & 141 & 11.22 & 29.76 & 22.93 & 20.49 & 15.61 \\
\hline V66 & $\begin{array}{l}\text { Teachers performs demonstrations, } \\
\text { but with learner participation, and } \\
\text { these demonstrations promote } \\
\text { inquiry (thinking) rather than just } \\
\text { illustrate concepts. }\end{array}$ & 2 & 144 & 2.91 & 16.50 & 25.73 & 28.64 & 26.21 \\
\hline V67 & $\begin{array}{l}\text { Teacher uses classroom demonstra- } \\
\text { tions to illustrate what content has } \\
\text { been taught. }\end{array}$ & 1 & 144 & 4.33 & 11.54 & 18.27 & 26.44 & 39.42 \\
\hline V68 & $\begin{array}{l}\text { Learners write scientific reports } \\
\text { that justify their conclusions in } \\
\text { terms of the data collected. }\end{array}$ & 3 & 142 & 16.18 & 26.96 & 21.08 & 24.02 & 11.76 \\
\hline
\end{tabular}

Note: $1=$ Never, 2 = Once a term, $3=$ Up to three times a term, $4=$ Once a week, $5=$ Every day. 
Table 6.4 shows data for items questioning science practical work. The level 1 practice was by far the most frequently exercised. There is not much of a difference in the frequency of use of levels 2 to 4 practices. However, it appears that the one level 4 practice (V65) is likely to have been misinterpreted by the teachers. If the teachers only interpreted the beginning of the item i.e. learners interpret data, then the results would be more in line with observations. However, interpreting data in support of competing theories or explanations is not likely to have occurred in most of the classrooms.

From the case studies it is evident that science practical work has not been included on a regular basis in many of the schools. In fact many classrooms have not achieved the level required under the old curriculum. Schools A, C, E, I and J were not seen to carry out any practical work at all. Schools D was seen to make some effort that did not quite reach level 1 practice. In this school the teacher reported doing a demonstration to show learners how to make a thermometer. The learners were not involved in the planning of this demonstration and no write-ups were required from the learners. School $\mathrm{F}$ showed science practical work implementation at level 1, however, the researcher reported that the science laboratory was very well equipped. School J did not quite reach level 2, but did more than would be required to be at level 1. In this school the learners were required to perform some kind of guided discovery activities. Two schools, B and

$\mathrm{G}$ showed a measure of progress towards better practical work, showing practices at levels 2 and 2,5 respectively. In these schools, demonstrations, guided type discovery activities and scientific reporting were regularly carried out.

\subsection{DATA ON CAPACITY OF SCHOOLS TO INNOVATE}

The construct "Capacity to Innovate" explores school-based factors that might enhance or hinder the implementation of new ideas and practices in the school. These factors include teacher factors, the schools environment (including ecology and management), physical resources and learner factors. Not all schools are equally furnished in these factors and therefore cannot be expected to carry out innovation at the same rate and extent. 


\subsubsection{Teacher factors}

The teachers' background, training, confidence and commitment to teaching have an impact on implementation. As in many parts of the world, many South African teachers lack adequate subject matter knowledge (Fuller \& Clarke, 1994), which in turn adversely affects innovation in the subject area.

Statements about factors that could influence implementation of Curriculum 2005 were provided in the questionnaire. Teachers were asked to indicate to what extent they agreed or disagreed with the statements based on the following Likert scale:

Table 6.5 Frequency percentages of teachers' perceptions

\begin{tabular}{|c|c|c|c|c|c|c|}
\hline & & $\mathbf{N}$ & 1 & 2 & 3 & 4 \\
\hline V69 & $\begin{array}{l}\text { If I were given the opportunity, I would leave } \\
\text { teaching this year. }\end{array}$ & 222 & 38.34 & 31.95 & 16.61 & 13.10 \\
\hline V70 & Morale in my school is low. & 220 & 17.80 & 40.13 & 26.54 & 15.53 \\
\hline V71 & $\begin{array}{l}\text { In my school teachers are willing to try new } \\
\text { teaching methods. }\end{array}$ & 211 & 4.08 & 9.18 & 47.28 & 39.46 \\
\hline V72 & $\begin{array}{l}\text { In my school we often discuss ideas and share } \\
\text { materials with colleagues who teach the same } \\
\text { subject. }\end{array}$ & 224 & 4.13 & 6.67 & 46.03 & 43.17 \\
\hline V73 & $\begin{array}{l}\text { In my circuit teachers from different schools meet } \\
\text { often so as to support and encourage one another. }\end{array}$ & 223 & 9.90 & 15.65 & 48.88 & 25.56 \\
\hline V74 & $\begin{array}{l}\text { Effective school-based in-service training happens } \\
\text { at my school. }\end{array}$ & 220 & 9.65 & 29.90 & 46.30 & 14.15 \\
\hline V75 & $\begin{array}{l}\text { In my circuit teachers meet with each other to } \\
\text { plan lessons. }\end{array}$ & 223 & 22.68 & 33.55 & 34.50 & 9.27 \\
\hline V76 & $\begin{array}{l}\text { Teachers in my school make an extra effort to } \\
\text { improve teaching and learning. }\end{array}$ & 220 & 2.59 & 5.50 & 54.37 & 37.54 \\
\hline V77 & $\begin{array}{l}\text { Teachers at my school are often not in the } \\
\text { classroom when they should be. }\end{array}$ & 224 & 47.77 & 34.71 & 13.69 & 3.82 \\
\hline V78 & $\begin{array}{l}\text { In my school, teachers reprimand learners for } \\
\text { providing incorrect answers e.g. by calling them } \\
\text { stupid. }\end{array}$ & 223 & 64.97 & 22.61 & 7.64 & 4.78 \\
\hline
\end{tabular}

Note: 1 = Strongly disagree, 2 = Disagree, 3 = Agree, 4 = Strongly agree .

V69 and V70 are items probing the general morale of the teachers. $70 \%$ of the teachers disagreed with the statement that they would leave teaching if they could. Also 58\% of the teachers disagreed that morale was low in their schools. Teacher morale generally can be said to be positive even though there are some teachers who indicated negativity. 
V71, V72 and V76 are all positive practices at the school level. Scores indicate that there is a generally positive attitude amongst teachers with them mostly agreeing with these statements. The two negative statements about school practices, V78 and V77, met with disagreement, supporting the general positive trend in schoolbased practices.

Variables 73 and 75 deal with teacher interaction within a region and reflect healthy collegiality beyond the school. It appears that this collegiality exists to a small extent and offers more encouragement and support rather than practical opportunity to work together, for example in designing lessons. Within their own schools, $60 \%$ of the teachers found that the in-service training was effective.

The case studies revealed also that teacher factors were positive in all schools, with seven of the ten schools at level 2 and the other three schools even better off than that. In general therefore, although teachers' individual capacities have not been investigated in this study, based on the questionnaire and observation data, it appears that there are no serious problems in terms of teacher factors with regards to their capacity to implement new innovation.

\subsubsection{School ecology and management}

A disorganised and dysfunctional school will not be able to take a new innovation onboard. The principal is the leader of the school and is therefore responsible for maintaining order and discipline within the school. The principal also plays a leadership role in other areas of implementation. The implementation has to be nurtured with planning and monitoring by the principal. The principal has to support and interact with his teachers as they implement change in a supportive manner in order to ensure the successful implementation over a period of time.

Teachers were asked to indicate to what extent they either agreed or disagreed with the following statements using the Likert scale below. The questions probed the way in which the school was managed and the kind of practices that were common. 
Table 6.6 Frequency percentages and means of school ethos and management

\begin{tabular}{|c|c|c|c|c|c|c|}
\hline & & $\mathbf{N}$ & $\begin{array}{c}\text { SD } \\
1\end{array}$ & $\begin{array}{l}\mathbf{D} \\
2\end{array}$ & $\begin{array}{l}\text { A } \\
3\end{array}$ & $\begin{array}{c}\text { SA } \\
4\end{array}$ \\
\hline V79 & I feel that my Principal supports me. & 224 & 4.47 & 4.79 & 54.63 & 36.10 \\
\hline V80 & I feel that my Head of Department supports me. & 218 & 1.65 & 5.61 & 52.15 & 40.59 \\
\hline V81 & $\begin{array}{l}\text { Staff participate in the management of the school } \\
\text { and therefore have a say in the running of the school }\end{array}$ & 220 & 7.42 & 15.48 & 46.13 & 30.97 \\
\hline V82 & Learners have a say in the running of the school. & 222 & 10.19 & 23.57 & 54.46 & 11.78 \\
\hline V83 & $\begin{array}{l}\text { Everyone in my school has a shared vision for the } \\
\text { school. }\end{array}$ & 221 & 7.40 & 20.26 & 48.87 & 23.47 \\
\hline V84 & Parents are actively involved with the school. & 218 & 11.94 & 24.52 & 42.90 & 20.65 \\
\hline V85 & In my school we follow the timetable strictly. & 222 & 0.96 & 6.09 & 44.55 & 48.40 \\
\hline V86 & $\begin{array}{l}\text { The principal often walks around to see what is } \\
\text { going on in the school. }\end{array}$ & 223 & 3.50 & 6.05 & 45.54 & 44.90 \\
\hline V87 & Extra mural activities interfere with classes. & 222 & 33.55 & 40.58 & 20.77 & 5.11 \\
\hline V88 & Learners are in class as scheduled. & 224 & 2.86 & 12.38 & 53.65 & 31.11 \\
\hline V89 & Teachers are in class as scheduled. & 224 & 1.90 & 6.65 & 54.11 & 37.34 \\
\hline
\end{tabular}

Note: 1 = Strongly disagree, 2 = Disagree, 3 = Agree, 4 = Strongly agree.

It appears that the principals and heads of department provided a supportive environment for the teachers. The teachers felt they were part of the school through being included in the running and management of the school. Parents and learners are not as involved in the management of the school as principals and teachers, an expected result. Variables 85, 86, 88 and 89 reflect the discipline within the school and in all cases the data indicates that good level of discipline is maintained. In general it appears that the school ethos and management in the schools in Mpumalanga support innovation. The only negative issue is that of extra-mural activity interfering with classes.

Once again, the case studies revealed that school ethos and management were positive in all schools with only School J being below level 2. All other schools are seen to be at level 2 or higher. In general, therefore, it appears that the situation in terms of school ecology and management is not bleak at all.

\subsubsection{Physical resources}

Resources are important in any curriculum implementation. Lack of resources, whether they be in the form of human resources, educational material or facilities makes both teaching and learning more challenging than need be.

Teachers were asked to indicate whether their school had the resources listed in table 6.7 by circling either the 'yes' or the 'no'. 
Table 6.7 Resources available at the schools

\begin{tabular}{|llll|}
\hline & Resource & N & Yes \\
\hline V90 & Teachers' guides & 212 & 80.74 \\
\hline V92 & Worksheets & 202 & 62.81 \\
\hline V94 & Science apparatus & 200 & 77.27 \\
\hline V96 & Maths apparatus & 191 & 40.96 \\
\hline V98 & Laboratory & 205 & 47.08 \\
\hline V100 & Photocopying facilities & 211 & 88.63 \\
\hline V102 & Running water & 209 & 68.58 \\
\hline V104 & Electricity & 213 & 88.00 \\
\hline V106 & Computers & 211 & 67.23 \\
\hline V108 & Library & 211 & 40.94 \\
\hline
\end{tabular}

C2005 has as part of its aims to get students and teachers to consult several sources for content information. The lack of library facilities and in some schools computers will hinder the move towards this form of information gathering. There is also a general shortage of mathematics apparatus and laboratories, although science apparatus is apparently well supplied. Although most school have electricity and running water, but it is a matter of concern that there are still schools without these basic essentials.

Interleaved within each of the above resources was an item asking teachers what impact they thought each resource had on the implementation of C2005. The effect on implementation was indicated using the following scale:

Table 6.8 Effect of a resource on implementation in percentages

\begin{tabular}{|llccccc} 
& Resource & N & N & S & M & L \\
\hline V91 & Teachers' guides & 192 & 13.77 & 20.65 & 44.57 & 21.01 \\
\hline V93 & Worksheets & 186 & 21.64 & 22.39 & 37.31 & 18.66 \\
\hline V95 & Science apparatus & 184 & 16.42 & 31.72 & 36.94 & 14.93 \\
\hline V97 & Maths apparatus & 163 & 42.37 & 23.31 & 19.49 & 14.83 \\
\hline V99 & Laboratory & 177 & 44.23 & 19.23 & 18.46 & 18.08 \\
\hline V101 & Photocopying facilities & 203 & 12.76 & 21.38 & 24.14 & 41.72 \\
\hline V103 & Running water & 194 & 24.19 & 16.61 & 24.19 & 35.02 \\
\hline V105 & Electricity & 199 & 13.03 & 16.20 & 27.46 & 43.31 \\
\hline V107 & Computers & 191 & 33.46 & 26.84 & 21.32 & 18.38 \\
\hline V109 & Library & 183 & 50.95 & 24.33 & 14.45 & 10.27 \\
\hline
\end{tabular}

Note: 1 = None $(\mathrm{N}), 2=$ Small $(\mathrm{S}), 3=$ Moderate $(\mathrm{M}), 4=$ Large $(\mathrm{L})$. 
The data in Table 6.8 indicate the perception that access to electricity has the greatest impact on C2005 implementation. Running water also features in the top four resources for successful C2005 implementation. In addition, having a photocopier and a teacher guide are important resources in the teachers' opinions for the implementation of C2005. These two resources are probably more needed now than ever before. The photocopier provides teachers with a means of sharing resources and making handouts for the learners. The teachers guide is seen as a necessary resource when a new curriculum innovation comes into practice. It provides teachers with support and gives them more confidence when beginning to incorporate new innovations.

Table 6.9 shows data about resources specifically supplied to learners. Teachers were asked to indicate to what extent each of the following resources are provided for learners at their schools. After each resource they were asked to circle one of the following numbers which have the meaning as indicated.

Table 6.9 Provision of learner resources in percentages

\begin{tabular}{|llrrrrrrr} 
& Resource & n & A & M & S & F & N \\
\hline V113 & Learner's textbooks & 221 & 23.72 & 21.47 & 29.81 & 12.18 & 12.82 \\
\hline V114 & Illustrated learning programs (ILP) & 207 & 7.12 & 11.86 & 22.71 & 22.71 & 35.59 \\
\hline V115 & Feeding scheme & 216 & 6.54 & 3.59 & 2.94 & 1.31 & 85.62 \\
\hline V116 & Place to study after school & 217 & 19.22 & 6.51 & 17.26 & 25.08 & 31.92 \\
\hline
\end{tabular}

Note: 1 = Almost all learners (A) 90\% - 100\%, 2 = Most learners (M) 70\% - 89\%, 3 = Some learners (S) $30 \%-69 \%, 4=$ Few learners (F) 10\% -29\%, 5 = Almost no learners (N) $0 \%-9 \%$.

It is often taken for granted in well resourced schools that all learners have textbooks. In fewer than half the schools in this study could it be said that most or almost all the learners have textbooks. Illustrated learning programs are rarely available. Feeding schemes, if they exist, are run by the local communities and are not provided by the government. Few schools had such schemes. In more than half the schools, few or no learners had a place to study after school.

Items V34 to V37 which occurred earlier in the questionnaire were aimed at establishing the access learners had to textbooks. In both the cases of the science books and the mathematics books, it appears that Grade 9's are better off with them in most cases having better access to the textbooks. The ideal situation would be that every learner has adequate access to textbooks, but for a large proportion of learners this does not seem to be the case (see table 6.10). Teachers 
report that much less than half their schools are in a position to supply each learner with a book. Almost the same percentage of learners in other schools has no access to textbooks at all.

Table 6.10 Access learners have to textbooks

\begin{tabular}{|lcccc|} 
& $\begin{array}{c}\text { Mathematics textbook access } \\
\text { (\% of learners) }\end{array}$ & \multicolumn{2}{c|}{$\begin{array}{c}\text { Natural science textbook } \\
\text { access (\% of learners) }\end{array}$} \\
\hline & Grade 8 (V34) & Grade 9 (V35) & Grade 8 (V37) & Grade 9 (V37) \\
\hline Almost all & 32.17 & 40.21 & 27.27 & 34.88 \\
\hline About three quarters & 12.17 & 17.53 & 20.20 & 12.79 \\
\hline About half & 10.43 & 14.43 & 10.10 & 22.09 \\
\hline About a quarter & 12.17 & 8.25 & 9.09 & 13.95 \\
\hline None & 33.04 & 19.59 & 33.33 & 16.28 \\
\hline
\end{tabular}

The case studies showed a variety of situations with respect to the access to physical resources. School A had no electricity in the classrooms, limiting the use of power dependant equipment such as overhead-projectors. This school also had no science practical equipment at all. Schools B and J had electricity, but no science practical equipment. School B had no library.

Schools E and I had science practical equipment available, and the facilities were kept in good condition. Schools C, D and G were better resourced with good buildings, electricity in all the classrooms and science practical equipment. School $\mathrm{F}$ and School $\mathrm{K}$ had all the resources above and in addition had excellent office equipment. The schools were well appointed in the classrooms, in laboratories and administration offices. Both these schools also had computer laboratories.

\subsubsection{Learner factors}

The background of the learners and the kinds of constraints they bring to the learning situation affect the implementation of new innovation. In many cases, South African learners do not have support at home for their studies. They may lack facilities to do homework, may have extensive domestic duties that keep them busy after school. In more severe circumstances, family and culture related commitments might require that a learner stays out of school for extended periods.

Teachers were asked to estimate the percentage of their learners that were described by the following statements about their background. The percentage 
ranges were irregular, but were felt by the questionnaire design team to be indicative of the groupings. After each category they were asked to circle one of the following numbers which have the meaning as indicated.

Table 6.11 Frequencies and means of learner factors

\begin{tabular}{|c|c|c|c|c|c|c|c|}
\hline & Category & $\mathbf{N}$ & A & $\mathbf{M}$ & S & $\mathbf{F}$ & $\mathbf{N}$ \\
\hline V117 & My learners come to school hungry. & 226 & 6.33 & 22.15 & 47.15 & 19.30 & 5.06 \\
\hline V118 & $\begin{array}{l}\text { My learners come from homes that have } \\
\text { electricity. }\end{array}$ & 226 & 17.41 & 28.48 & 36.08 & 14.24 & 3.80 \\
\hline V119 & $\begin{array}{l}\text { My learners come from homes that have } \\
\text { running water. }\end{array}$ & 224 & 16.24 & 14.01 & 26.43 & 24.20 & 19.11 \\
\hline V120 & My learners live in a safe neighbourhood. & 222 & 7.37 & 22.44 & 34.94 & 26.60 & 8.65 \\
\hline V121 & $\begin{array}{l}\text { The parents (or guardians) of my learners } \\
\text { have a matriculation (or higher) certificate. }\end{array}$ & 221 & 2.56 & 6.09 & 23.72 & 58.65 & 8.97 \\
\hline V122 & $\begin{array}{l}\text { The parents (or guardians) of my learners' } \\
\text { encourage them to study. }\end{array}$ & 226 & 4.43 & 10.76 & 35.44 & 43.04 & 6.33 \\
\hline V123 & $\begin{array}{l}\text { My learners are able to attend school } \\
\text { regularly. }\end{array}$ & 225 & 14.20 & 45.74 & 28.39 & 11.04 & 0.63 \\
\hline V124 & $\begin{array}{l}\text { Family duties and obligations keep my } \\
\text { learners out of school. }\end{array}$ & 223 & 3.50 & 15.61 & 36.62 & 32.80 & 11.46 \\
\hline V125 & My learners are old for their grade level. & 225 & 2.22 & 14.29 & 36.83 & 36.19 & 10.48 \\
\hline V126 & $\begin{array}{l}\text { My learners are proficient in the language } \\
\text { of instruction. }\end{array}$ & 220 & 5.90 & 12.79 & 36.72 & 38.69 & 5.90 \\
\hline V127 & My learners enjoy mathematics. & 209 & 4.71 & 14.14 & 44.11 & 35.02 & 2.02 \\
\hline V128 & My learners find science easy. & 206 & 1.36 & 11.22 & 44.22 & 39.12 & 4.08 \\
\hline V129 & $\begin{array}{l}\text { My learners have repeated at least one } \\
\text { year. }\end{array}$ & 225 & 0.32 & 7.62 & 33.97 & 48.57 & 9.52 \\
\hline
\end{tabular}

Note: 1 = Almost all learners (A) 90\%- 100\%, 2 = Most learners (M) 70\% - 89\%, $3=$ Some learners (S) $30 \%-69 \%, 4=$ Few learners (F) $10 \%-29 \%, 5=$ Almost no learners (N) $0 \%-9 \%$.

Poverty affects many learners in Mpumalanga. There are many children who come to school hungry and come from homes without electricity or running water. Only a few of the parents or guardians of the children have a matriculation certificate. It is understandable therefore that under-educated parents may not always be encouraging of the learners' education. In addition, the data indicate that it is often the case that family duties might keep students out of school. School attendance though, does not seem to be as big a problem as the other learner factors in the table. Therefore the lack of support at home would also further explain the number of students who have repeated at least one year during their schooling, resulting in them being old for their school level. 
Enjoyment of mathematics as a subject appears to be rather bleak, with many students not finding science easy either. It appears that pedagogic intervention is required in these two subjects as well as support for learners in their studies. A major factor of concern is that for most learners they are not proficient in the language of instruction.

The different schools in the case studies showed a variety of situations with regards the learner factors. School I has learners that are the worst off, with the school not achieving level 1. Although the researcher reported that the learners were in general well behaved, they often only attended the first session of school, skipping the session after break. It appeared that the learners might not have facilities at home to do homework and some had a high domestic workload at home which precluded them from doing homework. Their language proficiency in English was limited, which is problematic because the language of instruction at high school is English. School E achieved level 1 while School A was allocated a score at level 1,5. All the other schools were seen to be at level 2 or higher, with

School K, the ex-model C school, seen to be at level 3. Most learners who attend ex-model $\mathrm{C}$ schools come from more affluent homes. These homes often also provide more encouragement and facilities for learning.

\subsection{DATA ON OUTSIDE INFLUENCES}

Items were included in the questionnaire to try and get an idea of the measure of outside influence on the implementation of C2005 in Mpumalanga secondary schools. There are three types of outside influences considered, i.e.:

- change forces such as policy;

- peer support;

- professional development in terms of workshops and the effects different workshops from different sources had on the teacher;

- monitoring and accountability.

\subsubsection{Change forces}

Teachers were asked to circle one of the numbers which have the meaning as indicated for each of the items in table 6.14 that best indicates how much that item influences their willingness to implement Curriculum 2005. Each item represented a form of outside support and motivation. 
Table 6.12 Frequencies of factors influencing willingness to implement C2005

\begin{tabular}{|c|c|c|c|c|c|c|}
\hline & \multirow[t]{2}{*}{ Item } & \multirow[t]{2}{*}{$\mathbf{N}$} & \multicolumn{4}{|c|}{ Willingness to implement } \\
\hline & & & $N$ & $S$ & $M$ & $L$ \\
\hline V130 & Curriculum 2005 policy documents. & 220 & 6.51 & 24.10 & 39.09 & 30.29 \\
\hline V131 & Pressure from circuit managers. & 216 & 12.87 & 19.47 & 43.56 & 24.09 \\
\hline V132 & $\begin{array}{l}\text { Materials on Curriculum } 2005 \text { from the } \\
\text { Department of Education. }\end{array}$ & 217 & 11.48 & 28.85 & 37.70 & 21.97 \\
\hline V133 & $\begin{array}{l}\text { Support and encouragement from } \\
\text { Curriculum Implementers. }\end{array}$ & 220 & 2.92 & 21.10 & 42.53 & 33.44 \\
\hline V134 & $\begin{array}{l}\text { Concerns about disciplinary action being } \\
\text { taken against me. }\end{array}$ & 216 & 42.14 & 20.74 & 29.43 & 7.69 \\
\hline V135 & The support of teachers in my school. & 220 & 2.60 & 14.94 & 47.08 & 35.39 \\
\hline V136 & The expectations of my learners. & 217 & 2.63 & 18.75 & 51.64 & 26.97 \\
\hline V137 & Loyalty to my principal and/or HOD. & 219 & 2.61 & 9.80 & 39.87 & 47.71 \\
\hline V138 & $\begin{array}{l}\text { The support and encouragement of other } \\
\text { teachers in my cluster. }\end{array}$ & 219 & 5.23 & 13.73 & 43.79 & 37.25 \\
\hline
\end{tabular}

Note: $1=$ None, $2=$ Small, $3=$ Moderate, $4=$ Large.

The strongest motivational factor for teachers to implement the new curriculum is not the C2005 policy documents, but the teachers' direct line manager, the school principal. Teacher colleagues in the same school and cluster follow in the motivational strength. Curriculum implementers are also seen as motivational, with circuit managers contributing slightly less. Negative motivation does not play much of a role at all as few teachers fear disciplinary action for curriculum issues.

The change forces observed in the case studies were seen to be mostly at level 1, with change forces mainly coming from outside the school. The directive for change from the Provincial Department of Education was the primary source of motivation to change. Only Schools A and G operating at level 1,5. In School A, the Principal is also a driving force, while in School G, the researcher noted intrinsic motivation from the teachers.

\subsubsection{Professional development}

Teachers were asked whether or not they had attended any workshops on Curriculum 2005 since January 2001. They had to indicate either yes or no. 
Table 6.13 Teacher attendance of workshops since January 2001

$\begin{array}{cccc} & \text { N } & \text { Yes } & \text { No } \\ \text { V139 } & 217 & 90.16 \% & 9.84 \%\end{array}$

If they had answered that they had attended at least one workshop, they were asked to indicate the effect of the workshops on their implementation of Curriculum 2005. After each category they were asked to circle one of the following numbers which have the meaning as indicated.

Table 6.14 Effect of workshop on implementation of C2005

\begin{tabular}{|lrlrrrc} 
& N & Workshop service provider & \multicolumn{4}{c}{ Effect on implementation } \\
\hline V141 & 177 & Your school & 11.20 & 26.40 & 44.40 & 18.00 \\
\hline V143 & 183 & Department of Education & 2.67 & 21.76 & 48.85 & 26.72 \\
\hline V145 & 171 & Teacher Union & 36.25 & 26.67 & 26.67 & 10.42 \\
\hline V147 & 176 & MSSI & 9.45 & 12.20 & 41.73 & 36.61 \\
\hline V149 & 110 & NGO (specify) & 60.40 & 12.08 & 16.11 & 11.41 \\
\hline V152 & 101 & Education institutions (specify) & 54.42 & 10.88 & 22.45 & 12.24 \\
\hline
\end{tabular}

Note: 1 = None (N), 2 = Small (S), 3 = Moderate (M), 4 = Large $(\mathrm{L})$.

The MSSI and the Department of Education (DET) appear to be seen as providing the most useful workshops for C2005 implementation. Teacher Unions, Educational institutions and NGOs seem to have provided less useful support. In general however, all workshops were useful to at least some individuals.

During the case studies it was observed that teacher professional development in terms of implementation of C2005 provided reason for concern. Seven of the schools were allocate a score of 0 indicating that level one practice on the Professional development profile had not been attained, i.e. teachers at several schools had not received any training towards implementation of C2005. Schools $\mathrm{E}$ and $\mathrm{F}$ operated at level 1, having received some short training sessions. School G seems to be an exception, operating at a level of 2.5. In this school there is a program for professional development with an appraisal system. There is peer review amongst the teachers that is constructive and well received. It was noted, however, that this school received little opportunity from the outside for inservice education. Little or no long-term support has been offered to teachers as the new curriculum has been implemented. The training teachers have received has mostly comprised one-shot workshops which have been inadequate in ensuring sustainable change in teaching practice. 


\subsubsection{Monitoring and accountability}

Teachers were asked to what extent the persons in the table below monitor their school's compliance with the implementation of the Curriculum 2005 policy. After each statement they were asked to circle one of the following numbers which have the meaning as indicated.

Table 6.15 Persons who might monitor the school's compliance with curriculum implementation

\begin{tabular}{|llrrrrc} 
& Monitor & N & \multicolumn{5}{c}{ Compliance } \\
\hline V154 & Circuit managers & & \multicolumn{1}{c}{$N$} & \multicolumn{1}{c}{$S$} & \multicolumn{1}{c}{$M$} & \multicolumn{1}{c}{$L$} \\
\hline V155 & Teams from the department & 209 & 18.15 & 24.32 & 40.75 & 16.78 \\
\hline V156 & Curriculum implementers & 209 & 12.33 & 35.96 & 39.38 & 12.33 \\
\hline V157 & Principal & 210 & 5.44 & 21.77 & 44.90 & 27.89 \\
\hline V158 & HOD's & 209 & 8.56 & 20.89 & 39.04 & 31.51 \\
\hline V159 & Yourself & 209 & 6.87 & 17.53 & 42.61 & 32.99 \\
\hline
\end{tabular}

Note: $1=$ Not at all $(\mathrm{N}), 2=$ To a small extent $(\mathrm{S}), 3=$ To a moderate extent $(\mathrm{M}), 4=$ To a large extent (L).

It appears from the above data that teachers exhibit self monitoring in their implementation efforts. As the line management moves further from the teacher, i.e. HOD to principal to $\mathrm{CI}$, so the monitoring activity of that person decreases slightly. The least impact comes from the higher levels of the Education Department, viz. the circuit managers and the teams from the Department. This is not surprising as it is those people that the teacher has the most contact with that will be expected to have the greatest monitoring effect.

The 10 schools included in the case studies showed a variety of situations in terms of monitoring and accountability. Schools J and D (levels 0 and 0,5 respectively) had the biggest problem with this sub-construct. Schools E, F and I were seen to be at level 1. Schools A and G were well on the way to attaining independence from outside monitoring while School $\mathrm{K}$ seemed to have achieved the independence regarded in the profiles as ideal. 


\subsection{SUMMARY}

The results reported in this chapter provide a picture of what was observed and what was reported with respect to the sub-construct of each of the constructs in the Rogan-Grayson framework. The data do not provide any form of prediction i.e. what sub-constructs should be focused upon in order to improve assessment practice for example.

In terms of classroom interactions, it appears that most classes are still trying to get out of the starting blocks. Many more of the level 1 practices are used regularly with higher level practices being more rarely used. Schools' capacities to engage in new practices vary from school to school. Better resourced schools are at an advantage in that they have the material support required to bring about resource hungry change. In terms of outside support, it is clear that inservice training is very important in the success of change initiatives.

Inter-relationships between different sub-constructs cannot be reported from scores alone. In the next chapter, the data are subjected to more sophisticated statistical procedures in order to test for prediction and inter-relationships between constructs. 


\section{CHAPTER 7 \\ Inter-relationships between the constructs and the sub-constructs}

In this chapter, the data from the questionnaires were subjected to Spearman's correlation analysis and stepwise regression procedures using SPSS in order to discern relationships between the various sub-constructs of the Outside Influences and the Capacity to Innovate with those of the Profile of Implementation. Correlations between the variables within the four sub-constructs of the Profile of Implementation and those in the constructs Capacity to Innovate and Outside Influences are examined in section 7.1. In section 7.2 stepwise regressions between the same variables are investigated. In section 7.3 the statistical findings of the previous sections are summarized.

\subsection{CORRELATIONS}

The Rogan-Grayson framework contains several variables under the constructs Capacity to Innovate and Outside Influences that may have causal relationships with the sub-constructs of the Profile of Implementation. If such causal relationships could be found, they could inform curriculum implementation policy makers as to where the best investment in terms of time and money would be made to ensure successful curriculum implementation. In order to discern such relationships, the data from the first two mentioned constructs are correlated with data from the Profile of Implementation. Since the data are of ordinal strength only, the Spearman's rho correlation method was used (Keller \& Warrick, 2000). High correlations are indicative of a relationship between a particular item and an implementation sub-construct. 


\subsubsection{Creation of composite scores for the sub-constructs of the Profile of Implementation}

In order to explore possible relationships between 'Capacity to Innovate' and 'Outside factors' with the 'Profile of Implementation' sub-constructs, a single measure of each of the Profile of Implementation sub-constructs had to be created. The composite scores for the sub-constructs 'Classroom Interaction', 'Assessment Practice', 'Science Practical Work' and 'Science and Maths in Society' were all derived in a similar way. The detailed description of how the composite scores were calculated is given below for 'Classroom Interaction'.

The sub-construct "Classroom Interaction" of the Profile of Implementation was gauged by listing a number of practices that correspond to levels given in Chapter 3. In the questionnaire teachers were asked to indicate how frequently they might use each of the listed practices. These were scored as $1=$ Never, $2=$ Once a term, $3=\mathrm{Up}$ to three times a term, $4=$ Once a week and $5=$ Every day. The scores for all the Levels were averaged and then weighted according to the level. The weighted scores were summed to get a composite score. The weightings were as follows: Level one practices were not weighted. Level two practice scores were multiplied by 2, Level 3 by 3 and Level 4 by 4 . Below is an example of how a score for a single teacher was calculated:

\begin{tabular}{lcc} 
Variable & $\begin{array}{c}\text { Teacher } \\
\text { response }\end{array}$ & $\begin{array}{c}\text { Level of } \\
\text { practice }\end{array}$ \\
\hline V38 & 4 & 3 \\
\hline V39 & 4 & 1 \\
\hline V40 & 4 & 1 \\
\hline V41 & 4 & 2 \\
\hline V42 & 3 & 4 \\
\hline V43 & 1 & 1 \\
\hline V44 & 1 & 1 \\
\hline V45 & 5 & 4 \\
\hline V46 & 5 & 2 \\
\hline V47 & 5 & 2 \\
\hline V48 & 5 & 3 \\
\hline V49 & 5 & 4
\end{tabular}


The average for Level 1 practices would be $4+4+1+1=10,10 / 4=2.5$

The average for Level 2 practices would be $4+5+5=14,14 / 3=4.67,4.67 \times 2=9.3$

The average for Level 3 practices would be $4+5=9,9 / 2=4.5,4.5 \times 3=13.5$

The average for Level 4 practices would be $3+5+5=13,13 / 3=4.3,4.3 \times 4=17.3$

The composite score for this one record would be $2.5+9.3+13.5+17.3=42.6$.

The maximum score is calculated as follows:

Level 1 max (5) + Level 2 max (10) + Level 3 max (15) + Level 4 max (20) = 50.

The weighting of the scores gives higher scores to teachers who use higher level practices frequently and lower scores to teachers who mainly use lower level practices. A composite score was calculated in this manner for each teacher.

\subsubsection{Relationships between variables of the sub-constructs of Capacity to Innovate and the composite scores of the sub-constructs of the Profile of Implementation}

The construct Capacity to Innovate was measured using items within four subconstructs. These included teacher factors, learner factors, physical resources and the school ecology and management. Correlations between variables of these four sub-constructs and the composite scores for the sub-constructs of the Profile of Implantation are given in Tables $7.1-7.5$ on the next pages.

Teacher factors

Correlations and significances are shown in Table 7.1 on the next page.

Nearly all the items for Teacher Factors correlate significantly with at least one of the Profile of Implementation sub-constructs. The best predictor however is V75 In my circuit teachers meet each other to plan lessons, which correlates $(p<0.01)$ with all four of the Profile of Implementation sub-constructs. It is however a practice that less than half the teachers (43.77\%, see chapter 6) agreed was occurring. Sharing ideas and materials with teachers who teach the same subject in the school (V72), school-based in-service training (V74) and teachers' willingness to put in effort to improve teaching and learning (V76) also appear to be important to achieve higher level teaching practices. The practices of sharing materials and ideas and being willing to improve teaching and learning appear to 
be fairly widespread with $89.20 \%$ and $91.95 \%$ of the teachers agreeing that these practices occur. Only $60.45 \%$ of the teachers agreed that effective in-service training was happening in their schools.

Table 7.1 Correlation of Profile of Implementation composites correlated with variables of teacher factors

\begin{tabular}{|c|c|c|c|c|}
\hline & $\begin{array}{l}\text { Curriculum } \\
\text { implemen- } \\
\text { tation }\end{array}$ & Assessment & $\begin{array}{l}\text { Science } \\
\text { and maths } \\
\text { in society }\end{array}$ & $\begin{array}{c}\text { Science } \\
\text { practical } \\
\text { work }\end{array}$ \\
\hline & $\begin{array}{c}N=209- \\
221\end{array}$ & $\begin{array}{c}N=210- \\
223\end{array}$ & $\begin{array}{l}N=209- \\
222\end{array}$ & $\begin{array}{c}N=135- \\
146\end{array}$ \\
\hline $\begin{array}{l}\text { V69 - If I were given the } \\
\text { opportunity I would leave } \\
\text { teaching this year }\end{array}$ & $\begin{array}{c}-0.131 \\
\mathrm{p}=0.054\end{array}$ & $\begin{array}{c}-0.168^{*} \\
p=0.013\end{array}$ & $\begin{array}{c}-0.099 \\
p=0.236\end{array}$ & $\begin{array}{c}-0.092 \\
\mathrm{p}=0.174\end{array}$ \\
\hline $\begin{array}{l}\text { V70 - Morale in my school is } \\
\text { low }\end{array}$ & $\begin{array}{c}-0.107 \\
p=0.114\end{array}$ & $\begin{array}{c}-0.099 \\
p=0.143\end{array}$ & $\begin{array}{l}-0.206^{*} \\
p=0.014\end{array}$ & $\begin{array}{c}-0.119 \\
\mathrm{p}=0.079\end{array}$ \\
\hline $\begin{array}{l}\text { V71 - In my school teachers are } \\
\text { willing to try new teaching } \\
\text { methods }\end{array}$ & $\begin{array}{c}0.132 \\
p=0.056\end{array}$ & $\begin{array}{c}0.033 \\
\mathrm{p}=0.630\end{array}$ & $\begin{array}{c}0.126 \\
p=0.146\end{array}$ & $\begin{array}{l}0.191^{* *} \\
\mathrm{p}=0.006\end{array}$ \\
\hline $\begin{array}{l}\text { V72 - In my school we often } \\
\text { discuss ideas and share } \\
\text { materials with colleagues who } \\
\text { teach the same subject }\end{array}$ & $\begin{array}{c}0.152^{*} \\
p=0.024\end{array}$ & $\begin{array}{c}0.057 \\
p=0.393\end{array}$ & $\begin{array}{l}0.245^{* *} \\
\mathrm{p}=0.003\end{array}$ & $\begin{array}{c}0.091 \\
\mathrm{p}=0.174\end{array}$ \\
\hline $\begin{array}{l}\text { V73 - In my circuit teachers } \\
\text { from different schools meet } \\
\text { often so as to support and } \\
\text { encourage one another }\end{array}$ & $\begin{array}{c}0.095 \\
p=0.160\end{array}$ & $\begin{array}{c}0.146^{*} \\
p=0.030\end{array}$ & $\begin{array}{c}0.198^{*} \\
\mathrm{p}=0.017\end{array}$ & $\begin{array}{c}0.114 \\
p=0.091\end{array}$ \\
\hline $\begin{array}{l}\text { V74 - Effective school-based in- } \\
\text { service training happens at my } \\
\text { school }\end{array}$ & $\begin{array}{c}0.157^{*} \\
p=0.020\end{array}$ & $\begin{array}{c}0.092 \\
p=0.173\end{array}$ & $\begin{array}{l}0.304^{* *} \\
p=0.000\end{array}$ & $\begin{array}{c}0.177^{* *} \\
p=0.009\end{array}$ \\
\hline $\begin{array}{l}\text { V75 - In my circuit teachers } \\
\text { meet each other to plan lessons }\end{array}$ & $\begin{array}{c}0.255^{* *} \\
\mathrm{p}=0.000\end{array}$ & $\begin{array}{c}0.183^{* *} \\
p=0.006\end{array}$ & $\begin{array}{c}0.244^{* *} \\
p=0.003\end{array}$ & $\begin{array}{l}0.186^{* *} \\
p=0.006\end{array}$ \\
\hline $\begin{array}{l}\text { V76 - Teachers in my school } \\
\text { make an extra effort to improve } \\
\text { teaching and learning }\end{array}$ & $\begin{array}{c}0.152^{*} \\
p=0.026\end{array}$ & $\begin{array}{c}0.128 \\
\mathrm{p}=0.058\end{array}$ & $\begin{array}{l}0.216^{* *} \\
\mathrm{p}=0.010\end{array}$ & $\begin{array}{c}0.121 \\
\mathrm{p}=0.074\end{array}$ \\
\hline $\begin{array}{l}\text { V77 - Teachers at my school are } \\
\text { often not in the classroom when } \\
\text { they should be }\end{array}$ & $\begin{array}{l}-0.112 \\
p=0.097\end{array}$ & $\begin{array}{c}-0.089 \\
p=0.186\end{array}$ & $\begin{array}{c}-0.020 \\
p=0.807\end{array}$ & $\begin{array}{c}-0.150^{*} \\
p=0.026\end{array}$ \\
\hline $\begin{array}{l}\text { V78 - In my school, teachers } \\
\text { reprimand learners for provi- } \\
\text { ding incorrect answers e.g. by } \\
\text { calling them stupid }\end{array}$ & $\begin{array}{c}0.053 \\
p=0.433\end{array}$ & $\begin{array}{c}-0.103 \\
p=0.126\end{array}$ & $\begin{array}{c}0.073 \\
p=0.380\end{array}$ & $\begin{array}{c}-0.078 \\
p=0.247\end{array}$ \\
\hline
\end{tabular}

Note: ${ }^{* *}$ Correlation is significant at the 0.01 level, * Correlation is significant at the 0.05 level. 
The sub-construct of the Profile of Implementation most sensitive to the Teacher Factors is the linking of science and mathematics to societal issues. Sharing between teachers within the school and the circuit (V72, V73 \& V75) and teacher morale and willingness as well as in-service training are important in ensuring that science and mathematics are made relevant through linking them with societal issues. The Assessment sub-construct is the least influenced by all the items. It appears that preparing lessons with other teachers within the circuit influences assessment practices mostly. However, less than half the teachers $(45.77 \%)$ agree that this practice occurs. Item V69 - If I were given the opportunity I would leave teaching this year, is a significant, but negative, predictor of Assessment. This implies that where teachers say they do not want to leave teaching, assessment practice is higher. Only $29.71 \%$ of the teachers indicated that they would leave teaching if the opportunity arose.

\section{Learner factors}

Based on anecdotal evidence, the research team asked questions in the questionnaire which probed the socio-economic status of the learners, learner attitude to learning and parental inputs. Teachers were asked to answer fourteen questions about their learners as a group. Correlations between these questions and the Profile of Implementation constructs are shown in Table 7.2 below.

The most important learner factor is the teachers' perception of whether their learners find science easy (V128). Other factors that are important include parent or guardian qualifications and learner proficiency in the language of instruction (V121 \& V126 respectively). The many negative correlations are to be expected as most of the questions were phrased in the negative form. The fewer teachers agreeing with the negative statement, the better the sub-construct scores for the Profile of Implementation. Teaching the importance of science and mathematics in society does not seem to be affected by learner factors at all. Classroom interaction and science practical work are both influenced by parent or guardian qualifications (V121), Learner language proficiency (V126) and learners finding science easy (V128). None of the other factors appeared to influence the Profile of Implementation sub-constructs significantly. 
Table 7.2 Correlation of Profile of Implementation composites correlated with variables of learner factors

\begin{tabular}{|c|c|c|c|c|}
\hline & $\begin{array}{l}\text { Curriculum } \\
\text { implemen- } \\
\text { tation }\end{array}$ & Assessment & $\begin{array}{l}\text { Science } \\
\text { and maths } \\
\text { in society }\end{array}$ & $\begin{array}{c}\text { Science } \\
\text { practical } \\
\text { work }\end{array}$ \\
\hline & $\begin{array}{c}N=203- \\
224\end{array}$ & $\begin{array}{c}N=205- \\
226\end{array}$ & $\begin{array}{c}N=204- \\
224\end{array}$ & $\begin{array}{c}N=134- \\
147\end{array}$ \\
\hline $\begin{array}{l}\text { V117 - My learners come to school } \\
\text { hungry }\end{array}$ & $\begin{array}{c}0.015 \\
\mathrm{p}=0.828\end{array}$ & $\begin{array}{c}-0.075 \\
\mathrm{p}=0.263\end{array}$ & $\begin{array}{c}0.003 \\
\mathrm{p}=0.961\end{array}$ & $\begin{array}{c}0.052 \\
p=0.533\end{array}$ \\
\hline $\begin{array}{l}\text { V118 - My learners come from } \\
\text { homes that have electricity }\end{array}$ & $\begin{array}{c}-0.016 \\
\mathrm{p}=0.808\end{array}$ & $\begin{array}{c}0.125 \\
\mathrm{p}=0.062\end{array}$ & $\begin{array}{c}0.061 \\
p=0.360\end{array}$ & $\begin{array}{c}-0.054 \\
\mathrm{p}=0.512\end{array}$ \\
\hline $\begin{array}{l}\text { V119 - My learners come from } \\
\text { homes that have running water }\end{array}$ & $\begin{array}{l}-0.095 \\
\mathrm{p}=0.157\end{array}$ & $\begin{array}{c}0.003 \\
\mathrm{p}=0.968\end{array}$ & $\begin{array}{c}-0.060 \\
p=0.372\end{array}$ & $\begin{array}{c}-0.071 \\
p=0.398\end{array}$ \\
\hline $\begin{array}{l}\text { V120 - My learners live in a safe } \\
\text { neighbourhood }\end{array}$ & $\begin{array}{c}-0.054 \\
\mathrm{p}=0.426\end{array}$ & $\begin{array}{c}0.094 \\
\mathrm{p}=0.163\end{array}$ & $\begin{array}{l}-0.050 \\
\mathrm{p}=0.457\end{array}$ & $\begin{array}{c}-0.040 \\
p=0.634\end{array}$ \\
\hline $\begin{array}{l}\text { V121 - The parents (or guardians) } \\
\text { of my learners have a matric (or } \\
\text { higher) certificate }\end{array}$ & $\begin{array}{c}-0.154^{*} \\
p=0.032\end{array}$ & $\begin{array}{c}0.046 \\
p=0.497\end{array}$ & $\begin{array}{c}-0.092 \\
p=0.174\end{array}$ & $\begin{array}{c}-0.196^{*} \\
p=0.019\end{array}$ \\
\hline $\begin{array}{l}\text { V122 - - The parents (or guardians) } \\
\text { of my learners encourage them to } \\
\text { study }\end{array}$ & $\begin{array}{c}-0.107 \\
\mathrm{p}=0.112\end{array}$ & $\begin{array}{c}-0.012 \\
p=0.855\end{array}$ & $\begin{array}{c}0.042 \\
p=0.536\end{array}$ & $\begin{array}{c}-0.098 \\
p=0.239\end{array}$ \\
\hline $\begin{array}{l}\text { V123 - My learners are able to } \\
\text { attend school regularly }\end{array}$ & $\begin{array}{l}-0.050 \\
\mathrm{p}=0.456\end{array}$ & $\begin{array}{c}-0.008 \\
p=0.905\end{array}$ & $\begin{array}{c}0.038 \\
\mathrm{p}=0.576\end{array}$ & $\begin{array}{c}-0.146 \\
p=0.078\end{array}$ \\
\hline $\begin{array}{l}\text { V124 - Family duties and obliga- } \\
\text { tions keep my learners out of school }\end{array}$ & $\begin{array}{c}0.039 \\
p=0.568\end{array}$ & $\begin{array}{c}-0.114 \\
\mathrm{p}=0.089\end{array}$ & $\begin{array}{c}-0.060 \\
p=0.374\end{array}$ & $\begin{array}{c}-0.073 \\
\mathrm{p}=0.385\end{array}$ \\
\hline $\begin{array}{l}\text { V125 - My learners are old for their } \\
\text { grade level }\end{array}$ & $\begin{array}{c}-0.040 \\
p=0.555\end{array}$ & $\begin{array}{c}-0.073 \\
p=0.276\end{array}$ & $\begin{array}{c}-0.020 \\
p=0.771\end{array}$ & $\begin{array}{c}0.066 \\
p=0.426\end{array}$ \\
\hline $\begin{array}{l}\text { V126 - My learners are proficient } \\
\text { in the language of instruction }\end{array}$ & $\begin{array}{c}-0.163^{*} \\
p=0.016\end{array}$ & $\begin{array}{c}-0.085 \\
p=0.208\end{array}$ & $\begin{array}{c}-0.103 \\
p=0.131\end{array}$ & $\begin{array}{c}-0.184^{*} \\
p=0.028\end{array}$ \\
\hline $\begin{array}{l}\text { V127 - My learners enjoy } \\
\text { mathematics }\end{array}$ & $\begin{array}{l}-0.030 \\
\mathrm{p}=0.667\end{array}$ & $\begin{array}{c}-0.134 \\
\mathrm{p}=0.054\end{array}$ & $\begin{array}{c}0.060 \\
p=0.393\end{array}$ & $\begin{array}{c}-0.034 \\
\mathrm{p}=0.693\end{array}$ \\
\hline $\begin{array}{l}\text { V128 - My learners find science } \\
\text { easy }\end{array}$ & $\begin{array}{c}-0.143^{*} \\
p=0.041\end{array}$ & $\begin{array}{l}-0.163^{*} \\
p=0.019\end{array}$ & $\begin{array}{c}-0.107 \\
p=0.127\end{array}$ & $\begin{array}{l}-0.188^{*} \\
p=0.024\end{array}$ \\
\hline $\begin{array}{l}\text { V129 - My learners have repeated } \\
\text { at least one year }\end{array}$ & $\begin{array}{c}0.034 \\
\mathrm{p}=0.610\end{array}$ & $\begin{array}{c}-0.017 \\
\mathrm{p}=0.803\end{array}$ & $\begin{array}{c}0.048 \\
\mathrm{p}=0.474\end{array}$ & $\begin{array}{c}0.043 \\
\mathrm{p}=0.609\end{array}$ \\
\hline
\end{tabular}

Note: ${ }^{* *}$ Correlation is significant at the 0.01 level, ${ }^{*}$ Correlation is significant at the 0.05 level.

\section{Physical resources}

The correlations between the presence of particular resources and Profile of Implementation constructs are shown in Table 7.3 below. Teachers were asked whether some resources were available and also what they felt the impact was of having those resources on their teaching. 
Table 7.3 Correlation of Profile of Implementation composites correlated with variables of physical resources

\begin{tabular}{|c|c|c|c|c|}
\hline & $\begin{array}{l}\text { Curriculum } \\
\text { implementation }\end{array}$ & Assessment & $\begin{array}{l}\text { Science } \\
\text { and maths } \\
\text { in society }\end{array}$ & $\begin{array}{c}\text { Science } \\
\text { practical } \\
\text { work }\end{array}$ \\
\hline & $N=160-211$ & $N=177-211$ & $N=162-211$ & $N=116-139$ \\
\hline V90 - Teacher guides & $\begin{array}{c}0.050 \\
p=0.476\end{array}$ & $\begin{array}{c}0.058 \\
\mathrm{p}=0.400\end{array}$ & $\begin{array}{c}0.057 \\
p=0.409\end{array}$ & $\begin{array}{c}0.006 \\
p=0.949\end{array}$ \\
\hline V91 Perceived effect of above & $\begin{array}{c}0.146^{*} \\
p=0.044\end{array}$ & $\begin{array}{c}0.808 \\
p=0.268\end{array}$ & $\begin{array}{c}0.014 \\
p=0.843\end{array}$ & $\begin{array}{c}0.217^{*} \\
p=0.015\end{array}$ \\
\hline V92 - Worksheets & $\begin{array}{c}0.045 \\
p=0.526\end{array}$ & $\begin{array}{c}0.095 \\
\mathrm{p}=0.180\end{array}$ & $\begin{array}{c}0.052 \\
p=0.468\end{array}$ & $\begin{array}{l}0.225^{\star *} \\
p=0.009\end{array}$ \\
\hline V93 Perceived effect of above & $\begin{array}{c}0.043 \\
\mathrm{p}=0.566\end{array}$ & $\begin{array}{c}-0.041 \\
p=0.580\end{array}$ & $\begin{array}{c}0.045 \\
p=0.547\end{array}$ & $\begin{array}{c}0.207^{*} \\
p=0.022\end{array}$ \\
\hline V94 - Science apparatus & $\begin{array}{c}-0.045 \\
p=0.527\end{array}$ & $\begin{array}{c}-0.015 \\
p=0.836\end{array}$ & $\begin{array}{c}-0.131 \\
p=0.065\end{array}$ & $\begin{array}{c}0.134 \\
p=0.118\end{array}$ \\
\hline V95 Perceived effect of above & $\begin{array}{c}0.032 \\
p=0.673\end{array}$ & $\begin{array}{c}-0.017 \\
\mathrm{p}=0.820\end{array}$ & $\begin{array}{c}-0.068 \\
p=0.358\end{array}$ & $\begin{array}{c}0.153 \\
\mathrm{p}=0.089\end{array}$ \\
\hline V96 - Maths apparatus & $\begin{array}{c}-0.097 \\
p=0.186\end{array}$ & $\begin{array}{c}0.076 \\
\mathrm{p}=0.300\end{array}$ & $\begin{array}{c}-0.150^{*} \\
p=0.039\end{array}$ & $\begin{array}{c}0.256^{* *} \\
p=0.005\end{array}$ \\
\hline V97 Perceived effect of above & $\begin{array}{c}-0.133 \\
p=0.094\end{array}$ & $\begin{array}{c}-0.038 \\
p=0.630\end{array}$ & $\begin{array}{c}-0.076 \\
p=0.338\end{array}$ & $\begin{array}{c}0.156 \\
p=0.115\end{array}$ \\
\hline V98 - Laboratory & $\begin{array}{c}0.073 \\
p=0.301\end{array}$ & $\begin{array}{c}0.024 \\
p=0.730\end{array}$ & $\begin{array}{c}-0.106 \\
p=0.134\end{array}$ & $\begin{array}{c}0.127 \\
p=0.144\end{array}$ \\
\hline V99 Perceived effect of above & $\begin{array}{c}0.077 \\
p=0.311\end{array}$ & $\begin{array}{c}0.043 \\
p=0.569\end{array}$ & $\begin{array}{c}-0.055 \\
p=0.465\end{array}$ & $\begin{array}{c}0.113 \\
p=0.228\end{array}$ \\
\hline V100 - Photocopying facilities & $\begin{array}{c}0.155^{*} \\
p=0.025\end{array}$ & $\begin{array}{c}-0.030 \\
p=0.668\end{array}$ & $\begin{array}{c}-0.041 \\
p=0.556\end{array}$ & $\begin{array}{c}0.085 \\
p=0.0321\end{array}$ \\
\hline V101 Perceived effect of above & $\begin{array}{c}0.019 \\
p=0.792\end{array}$ & $\begin{array}{c}0.011 \\
p=0.879\end{array}$ & $\begin{array}{c}-0.089 \\
p=0.210\end{array}$ & $\begin{array}{c}0.148 \\
\mathrm{p}=0.089\end{array}$ \\
\hline V102 - Running water & $\begin{array}{c}0.111 \\
p=0.112\end{array}$ & $\begin{array}{c}0.018 \\
p=0.793\end{array}$ & $\begin{array}{c}0.020 \\
p=0.771\end{array}$ & $\begin{array}{c}0.095 \\
p=0.271\end{array}$ \\
\hline V103 Perceived effect of above & $\begin{array}{c}0.160^{*} \\
p=0.027\end{array}$ & $\begin{array}{c}-0.006 \\
p=0.933\end{array}$ & $\begin{array}{c}0.079 \\
p=0.274\end{array}$ & $\begin{array}{c}0.091 \\
p=0.308\end{array}$ \\
\hline V104 - Electricity & $\begin{array}{c}0.107 \\
\mathrm{p}=0.122\end{array}$ & $\begin{array}{c}-0.014 \\
p=0.840\end{array}$ & $\begin{array}{c}-0.004 \\
p=0.953\end{array}$ & $\begin{array}{c}-0.011 \\
p=0.899\end{array}$ \\
\hline V105 Perceived effect of above & $\begin{array}{c}0.136 \\
p=0.057\end{array}$ & $\begin{array}{c}0.080 \\
p=0.264\end{array}$ & $\begin{array}{c}0.053 \\
p=0.458\end{array}$ & $\begin{array}{c}0.240^{* *} \\
\mathrm{p}=0.006\end{array}$ \\
\hline V106 - Computers & $\begin{array}{c}-0.003 \\
p=0.963\end{array}$ & $\begin{array}{c}-0.036 \\
p=0.602\end{array}$ & $\begin{array}{c}-0.058 \\
p=0.402\end{array}$ & $\begin{array}{c}0.155 \\
p=0.069\end{array}$ \\
\hline V107 Perceived effect of above & $\begin{array}{c}0.055 \\
p=0.455\end{array}$ & $\begin{array}{c}-0.007 \\
p=0.922\end{array}$ & $\begin{array}{c}-0.016 \\
p=0.824\end{array}$ & $\begin{array}{c}0.166 \\
p=0.068\end{array}$ \\
\hline V108 - Library & $\begin{array}{c}-0.038 \\
p=0.589\end{array}$ & $\begin{array}{c}-0.024 \\
p=0.727\end{array}$ & $\begin{array}{c}-0.097 \\
p=0.163\end{array}$ & $\begin{array}{c}0.056 \\
p=0.515\end{array}$ \\
\hline
\end{tabular}


Table 7.3 Correlation of Profile of Implementation composites correlated with variables of physical resources (Continued)

\begin{tabular}{|c|c|c|c|c|}
\hline & $\begin{array}{c}\text { Curriculum } \\
\text { implementation }\end{array}$ & Assessment & $\begin{array}{c}\text { Science } \\
\text { and maths } \\
\text { in society }\end{array}$ & $\begin{array}{c}\text { Science } \\
\text { practical } \\
\text { work }\end{array}$ \\
\hline & $N=160-211$ & $N=177-211$ & $N=162-211$ & $N=116-139$ \\
\hline V109 Perceived effect of above & $\begin{array}{l}-0.026 \\
p=0729\end{array}$ & $\begin{array}{c}0.070 \\
\mathrm{p}=0.345\end{array}$ & $\begin{array}{c}-0.069 \\
p=0.358\end{array}$ & $\begin{array}{l}-0.045 \\
p=0625\end{array}$ \\
\hline V113 - Learner's textbooks & $\begin{array}{c}0.066 \\
\mathrm{p}=0.330\end{array}$ & $\begin{array}{l}-0.238^{* *} \\
p=0.001\end{array}$ & $\begin{array}{c}-0.087 \\
\mathrm{p}=0.205\end{array}$ & $\begin{array}{l}-0.183^{* *} \\
p=0.007\end{array}$ \\
\hline $\begin{array}{l}\text { V114 - Illustrated learning } \\
\text { programs }\end{array}$ & $\begin{array}{c}0.085 \\
p=0.209\end{array}$ & $\begin{array}{c}-0.131 \\
p=0.060\end{array}$ & $\begin{array}{l}-0.058 \\
\mathrm{p}=0.401\end{array}$ & $\begin{array}{l}-0.158^{*} \\
p=0.020\end{array}$ \\
\hline V115 - Feeding scheme & $\begin{array}{c}-0.021 \\
\mathrm{p}=0.806\end{array}$ & $\begin{array}{l}-0.295^{* *} \\
p=0.000\end{array}$ & $\begin{array}{c}-0.075 \\
\mathrm{p}=0.384\end{array}$ & $\begin{array}{l}-0.211^{*} \\
\mathrm{p}=0.012\end{array}$ \\
\hline $\begin{array}{l}\text { V116 - Place to study after } \\
\text { school }\end{array}$ & $\begin{array}{l}-0.005 \\
p=0.936\end{array}$ & $\begin{array}{l}-0.158^{*} \\
p=0.024\end{array}$ & $\begin{array}{c}-0.092 \\
p=0.178\end{array}$ & $\begin{array}{c}-0.015 \\
p=0.832\end{array}$ \\
\hline
\end{tabular}

Note: ${ }^{* *}$ Correlation is significant at the 0.01 level, ${ }^{*}$ Correlation is significant at the 0.05 level.

The availability of worksheets, maths apparatus and photocopying facilities (V92, V96 \& V100) all appear to significantly contribute towards at least one of the Profile of Implementation sub-constructs. Worksheets are important for science practical work. Worksheets allow for independent and focussed work by the learner, a move towards learner-centeredness. Worksheets therefore could be seen as indicative of higher level science practical work. Because only $40.96 \%$ of the teachers indicated that they had access to maths apparatus teachers, maths apparatus (V96) has a negative correlation with the teaching of science and mathematics in societal contexts. It is interesting to note that teachers perceive the effect of teacher guides (V90), running water (V103) and electricity (V104) to be significant, when their presence is not statistically significant. The strongest correlation, oddly, is with V96 - Maths apparatus and science practical work.

\section{School ecology and management}

Teachers were asked to respond to eleven statements about the overall ethos or ecology and more specifically the management of their school. The correlations of these items with the Profile of Implementation sub-constructs are shown in Table 7.4 on the next page. 
Table 7.4 Correlation of Profile of Implementation composites correlated with variables of Ecology and management

\begin{tabular}{|c|c|c|c|c|}
\hline & $\begin{array}{l}\text { Curriculum } \\
\text { implement- } \\
\text { tation } \\
\text { composite }\end{array}$ & $\begin{array}{l}\text { Assessment } \\
\text { composite }\end{array}$ & $\begin{array}{l}\text { Science and } \\
\text { maths in } \\
\text { society }\end{array}$ & $\begin{array}{c}\text { Science } \\
\text { practical } \\
\text { work }\end{array}$ \\
\hline & $\begin{array}{c}N=215- \\
221\end{array}$ & $\begin{array}{c}N=217- \\
223\end{array}$ & $\begin{array}{c}N=216- \\
223\end{array}$ & $\begin{array}{c}N=141- \\
147\end{array}$ \\
\hline $\begin{array}{l}\text { V79 - I feel that my principal } \\
\text { supports me }\end{array}$ & $\begin{array}{c}0.010 \\
\mathrm{p}=0.883\end{array}$ & $\begin{array}{c}0.135^{*} \\
\mathrm{p}=0.044\end{array}$ & $\begin{array}{c}0.021 \\
\mathrm{p}=0.759\end{array}$ & $\begin{array}{c}0.166^{*} \\
p=0.045\end{array}$ \\
\hline $\begin{array}{l}\text { V80 - I feel that my HOD } \\
\text { supports me }\end{array}$ & $\begin{array}{c}0.093 \\
\mathrm{p}=0.175\end{array}$ & $\begin{array}{l}0.215^{* *} \\
p=0.001\end{array}$ & $\begin{array}{c}0.153^{*} \\
\mathrm{p}=0.024\end{array}$ & $\begin{array}{c}0.122 \\
p=0.14\end{array}$ \\
\hline $\begin{array}{l}\text { V81 - Staff participate in the } \\
\text { management of the school and } \\
\text { therefore have a say in the } \\
\text { running of the school }\end{array}$ & $\begin{array}{c}0.083 \\
p=0.226\end{array}$ & $\begin{array}{c}0.087 \\
p=0.198\end{array}$ & $\begin{array}{c}0.103 \\
p=0.129\end{array}$ & $\begin{array}{l}0.247^{* *} \\
p=0.003\end{array}$ \\
\hline $\begin{array}{l}\text { V82 - Learners have a say in the } \\
\text { running of the school }\end{array}$ & $\begin{array}{c}0.188^{* *} \\
\mathrm{p}=0.005\end{array}$ & $\begin{array}{c}0.131 \\
\mathrm{p}=0.053\end{array}$ & $\begin{array}{l}0.195^{* *} \\
\mathrm{p}=0.004\end{array}$ & $\begin{array}{l}0.228^{* *} \\
p=0.006\end{array}$ \\
\hline $\begin{array}{l}\text { V83 - Everyone in my school has } \\
\text { a shared vision for the school }\end{array}$ & $\begin{array}{l}0.234^{* *} \\
p=0.000\end{array}$ & $\begin{array}{l}0.240^{* *} \\
p=0.000\end{array}$ & $\begin{array}{l}0.232^{* *} \\
p=0.001\end{array}$ & $\begin{array}{l}0.283^{* *} \\
p=0.001\end{array}$ \\
\hline $\begin{array}{l}\text { V84 - Parents are actively } \\
\text { involved with school }\end{array}$ & $\begin{array}{l}0.231^{* *} \\
p=0.001\end{array}$ & $\begin{array}{c}0.165^{*} \\
p=0.015\end{array}$ & $\begin{array}{c}0.26^{* *} \\
p=0.002\end{array}$ & $\begin{array}{c}0.170^{*} \\
\mathrm{p}=0.044\end{array}$ \\
\hline $\begin{array}{l}\text { V85 - In my school we follow } \\
\text { the timetable strictly }\end{array}$ & $\begin{array}{c}0.088 \\
\mathrm{p}=0.193\end{array}$ & $\begin{array}{c}0.105 \\
p=0.124\end{array}$ & $\begin{array}{c}0.101 \\
\mathrm{p}=0.881\end{array}$ & $\begin{array}{c}0.083 \\
\mathrm{p}=0.321\end{array}$ \\
\hline $\begin{array}{l}\text { V86 - The principal often walks } \\
\text { around to see what is going on } \\
\text { in the school }\end{array}$ & $\begin{array}{c}0.091 \\
p=0.179\end{array}$ & $\begin{array}{c}0.100 \\
p=0.138\end{array}$ & $\begin{array}{c}0.094 \\
p=0.166\end{array}$ & $\begin{array}{c}0.066 \\
p=0.432\end{array}$ \\
\hline $\begin{array}{l}\text { V87 - Extramural activities } \\
\text { interfere with classes }\end{array}$ & $\begin{array}{c}-0.057 \\
\mathrm{p}=0.398\end{array}$ & $\begin{array}{c}-0.505 \\
p=0.549\end{array}$ & $\begin{array}{l}-0.174^{* *} \\
p=0.101\end{array}$ & $\begin{array}{c}0.031 \\
\mathrm{p}=0.713\end{array}$ \\
\hline $\begin{array}{l}\text { V88 - Learners are in class as } \\
\text { scheduled }\end{array}$ & $\begin{array}{l}0.179^{* *} \\
p=0.008\end{array}$ & $\begin{array}{c}0.098 \\
p=0.143\end{array}$ & $\begin{array}{c}0254^{* *} \\
p=0.000\end{array}$ & $\begin{array}{c}0.110 \\
p=0.184\end{array}$ \\
\hline $\begin{array}{l}\text { V89 - Teachers are in class as } \\
\text { scheduled }\end{array}$ & $\begin{array}{c}0.130 \\
\mathrm{p}=0.054\end{array}$ & $\begin{array}{c}0.109 \\
p=0.103\end{array}$ & $\begin{array}{c}0.143^{*} \\
\mathrm{p}=0.033\end{array}$ & $\begin{array}{c}0.061 \\
p=0.465\end{array}$ \\
\hline
\end{tabular}

Note: ${ }^{* *}$ Correlation is significant at the 0.01 level, ${ }^{*}$ Correlation is significant at the 0.05 level.

A shared vision for the school (V83) and parents' active involvement in the school (V84) appear to be significant inputs into the Profile of Implementation. Learners having a say in the running of the school (V82) seems also to be important for all except the Assessment sub-construct. The sub-construct 'Science and Maths in Society' is the most sensitive to School Ecology and Management factors with HOD support (V80), learners having a say in the running of the school (V82), a shared vision for the school (V83), and active parental 
involvement in the school (V84) all having significant correlations with Science and Maths in Society composite score. Also important for this sub-construct is school discipline indicated by learners and teachers being in the classroom in scheduled times (V88 and V89) and the fact that classes are not interrupted by extramural activities (V87) indicated by the negative correlation. The other constructs are affected by fewer of the items.

\subsubsection{Relationships between variables of the sub-constructs of Outside Influences and the composite scores of the sub-constructs of the Profile of Implementation}

Outside Influences are the drivers for change from within the education system, but from outside a particular classroom. Three sub-constructs of Outside Influences were defined in the study. Firstly professional development was considered. Here the number of days teachers indicated they had training in C2005 practices was considered along with their perceptions of how much the training helped them in implementing C2005. Secondly change forces were measured. Change forces included C2005 policy documents, pressure from the line management, collegiality amongst peers as well as the influence of the learners. Thirdly, the affect that monitoring and accountability had on implementation was looked at. Here the effects of specific people or groups of people within the education system were considered. The correlation between

these three sub-constructs of Outside Influences and the Profile of Implementation are given in Table 7.5. 
Table 7.5 Correlation of Profile of Implementation composites correlated with variables of Outside Influences

\begin{tabular}{|c|c|c|c|c|}
\hline & $\begin{array}{l}\text { Curriculum } \\
\text { implemen- } \\
\text { tation }\end{array}$ & Assessment & $\begin{array}{l}\text { Science and } \\
\text { maths in } \\
\text { society }\end{array}$ & $\begin{array}{c}\text { Science } \\
\text { practical } \\
\text { work }\end{array}$ \\
\hline \multicolumn{5}{|l|}{ Professional Development } \\
\hline $\begin{array}{l}\text { V139 - Whether or not } \\
\text { workshops have been attended }\end{array}$ & $\begin{array}{c}0.002 \\
\mathrm{p}=0.975\end{array}$ & $\begin{array}{c}-0.058 \\
p=0.383\end{array}$ & $\begin{array}{c}0.018 \\
p=0.786\end{array}$ & $\begin{array}{c}-0.079 \\
\mathrm{p}=0.342\end{array}$ \\
\hline $\begin{array}{l}\text { V140 - Workshops offered by } \\
\text { Your school }\end{array}$ & $\begin{array}{c}0.134 \\
p=0.574 \\
N=20\end{array}$ & $\begin{array}{c}-0.128 \\
p=0.591 \\
N=20\end{array}$ & $\begin{array}{c}-0.217 \\
p=0.357 \\
N=20\end{array}$ & $\begin{array}{c}0.253 \\
p=0.383 \\
N=14\end{array}$ \\
\hline $\begin{array}{l}\text { V142 - Workshops offered by } \\
\text { Department of Education }\end{array}$ & $\begin{array}{c}0.226 \\
p=0.313 \\
N=22\end{array}$ & $\begin{array}{c}-0.011 \\
p=0.962 \\
N=22\end{array}$ & $\begin{array}{c}-0.092 \\
p=0.685 \\
N=22\end{array}$ & $\begin{array}{c}0.223 \\
p=0.443 \\
N=14\end{array}$ \\
\hline $\begin{array}{l}\text { V144 - Workshops offered by } \\
\text { Teacher union }\end{array}$ & $\begin{array}{c}0.264 \\
p=0.567 \\
N=7\end{array}$ & $\begin{array}{c}0.157 \\
p=0.737 \\
N=7\end{array}$ & $\begin{array}{c}0.472 \\
p=0.285 \\
N=7\end{array}$ & $\begin{array}{c}0.564 \\
p=0.322 \\
N=5\end{array}$ \\
\hline $\begin{array}{l}\text { V146 - Workshops offered by } \\
\text { MSSI }\end{array}$ & $\begin{array}{c}0.117 \\
p=0.677 \\
N=15\end{array}$ & $\begin{array}{c}0.071 \\
p=0.802 \\
N=15\end{array}$ & $\begin{array}{c}-0.260 \\
p=0.348 \\
N=15\end{array}$ & $\begin{array}{c}0.238 \\
p=0.508 \\
N=10\end{array}$ \\
\hline \multicolumn{5}{|l|}{ Change forces } \\
\hline $\begin{array}{l}\text { V130- Curriculum } 2005 \\
\text { documents }\end{array}$ & $\begin{array}{c}0.170 * \\
p=0.012 \\
N=217\end{array}$ & $\begin{array}{c}0.142^{*} \\
p=0.035 \\
N=219\end{array}$ & $\begin{array}{c}0.133 \\
p=0.051 \\
N=218\end{array}$ & $\begin{array}{l}0.280^{* *} \\
p=0.001 \\
N=141\end{array}$ \\
\hline $\begin{array}{l}\text { V131- Pressure from Circuit } \\
\text { Managers }\end{array}$ & $\begin{array}{c}0.077 \\
p=0.260 \\
N=213\end{array}$ & $\begin{array}{c}0.010 \\
p=0.889 \\
N=215\end{array}$ & $\begin{array}{c}0.076 \\
p=0.266 \\
N=214\end{array}$ & $\begin{array}{c}0.166 \\
p=0.051 \\
N=139\end{array}$ \\
\hline $\begin{array}{l}\text { V132- materials on Curriculum } \\
2005 \text { from the Department of } \\
\text { Education }\end{array}$ & $\begin{array}{c}0.137^{*} \\
p=0.045 \\
N=214\end{array}$ & $\begin{array}{c}0.144^{*} \\
p=0.034 \\
N=216\end{array}$ & $\begin{array}{c}0.107 \\
p=0.116 \\
N=215\end{array}$ & $\begin{array}{c}0.172^{*} \\
p=0.043 \\
N=139\end{array}$ \\
\hline $\begin{array}{l}\text { V133- Support and } \\
\text { encouragement from } \\
\text { Curriculum Implementers }\end{array}$ & $\begin{array}{c}0.048 \\
p=0.481 \\
N=218\end{array}$ & $\begin{array}{c}0.055 \\
p=0.416 \\
N=219\end{array}$ & $\begin{array}{c}0.056 \\
p=0.412 \\
N=218\end{array}$ & $\begin{array}{c}0.110 \\
p=0.196 \\
N=141\end{array}$ \\
\hline $\begin{array}{l}\text { V134- Concerns about } \\
\text { disciplinary action being taken } \\
\text { against me }\end{array}$ & $\begin{array}{c}0.093 \\
p=0.178 \\
N=213\end{array}$ & $\begin{array}{l}-0.042 \\
p=0.538 \\
N=215\end{array}$ & $\begin{array}{c}0.127 \\
p=0.064 \\
N=214\end{array}$ & $\begin{array}{c}0.031 \\
p=0.712 \\
N=140\end{array}$ \\
\hline $\begin{array}{l}\text { V135- The support of teachers in } \\
\text { my school }\end{array}$ & $\begin{array}{l}0.135^{*} \\
p=0.047 \\
N=217\end{array}$ & $\begin{array}{c}0.118 \\
p=0.082 \\
N=219\end{array}$ & $\begin{array}{l}0.202^{* *} \\
\mathrm{p}=0.003 \\
\mathrm{~N}=218\end{array}$ & $\begin{array}{c}0.154 \\
\mathrm{p}=0.068 \\
\mathrm{~N}=141\end{array}$ \\
\hline $\begin{array}{l}\text { V136- The expectations of my } \\
\text { learners }\end{array}$ & $\begin{array}{c}0.123 \\
p=0.073 \\
N=215\end{array}$ & $\begin{array}{c}0.105 \\
p=0.122 \\
N=216\end{array}$ & $\begin{array}{c}0.100 \\
p=0.145 \\
N=215\end{array}$ & $\begin{array}{c}0.137 \\
p=0.107 \\
N=140\end{array}$ \\
\hline $\begin{array}{l}\text { V137- Loyalty to my principal } \\
\text { and/or HOD }\end{array}$ & $\begin{array}{c}0.040 \\
p=0.556 \\
N=216\end{array}$ & $\begin{array}{c}0.159 * \\
p=0.019 \\
N=218\end{array}$ & $\begin{array}{c}-0.049 \\
p=0.469 \\
N=217\end{array}$ & $\begin{array}{c}0.047 \\
\mathrm{p}=0.581 \\
\mathrm{~N}=141\end{array}$ \\
\hline
\end{tabular}


Table 7.5 Correlation of Profile of Implementation composites correlated with variables of Outside Influences (Continued)

\begin{tabular}{|c|c|c|c|c|}
\hline & $\begin{array}{l}\text { Curriculum } \\
\text { implemen- } \\
\text { tation }\end{array}$ & Assessment & $\begin{array}{l}\text { Science and } \\
\text { maths in } \\
\text { society }\end{array}$ & $\begin{array}{c}\text { Science } \\
\text { practical } \\
\text { work }\end{array}$ \\
\hline $\begin{array}{l}\text { V138- The support and } \\
\text { encouragement of other teachers } \\
\text { in my cluster. }\end{array}$ & $\begin{array}{c}0.123 \\
p=0.070 \\
N=216\end{array}$ & $\begin{array}{l}0.190^{* *} \\
p=0.005 \\
N=218\end{array}$ & $\begin{array}{c}0.087 \\
\mathrm{p}=0.202 \\
\mathrm{~N}=217\end{array}$ & $\begin{array}{c}0.150 \\
\mathrm{p}=0.075 \\
\mathrm{~N}=141\end{array}$ \\
\hline \multicolumn{5}{|c|}{$\begin{array}{l}\text { Monitoring and Accountability } \\
\text { To what extent do the following persons monitor your school's compliance with the } \\
\text { implementation of the Curriculum } 2005 \text { policy? }\end{array}$} \\
\hline V154 - Circuit managers & $\begin{array}{c}0.173^{*} \\
\mathrm{p}=0.013 \\
\mathrm{~N}=207\end{array}$ & $\begin{array}{c}0.104 \\
\mathrm{p}=0.133 \\
\mathrm{~N}=208\end{array}$ & $\begin{array}{l}0.192^{* *} \\
\mathrm{p}=0.006 \\
\mathrm{~N}=207\end{array}$ & $\begin{array}{l}0.306^{* *} \\
\mathrm{p}=0.000 \\
\mathrm{~N}=134\end{array}$ \\
\hline $\begin{array}{l}\text { V155 - Teams from the } \\
\text { Department }\end{array}$ & $\begin{array}{l}0.153^{*} \\
p=0.028 \\
N=207\end{array}$ & $\begin{array}{c}0.110 \\
p=0.113 \\
N=208\end{array}$ & $\begin{array}{l}0.125 \\
p=0.073 \\
N=207\end{array}$ & $\begin{array}{c}0.249^{* *} \\
p=0.004 \\
N=135\end{array}$ \\
\hline $\begin{array}{l}\text { V156 - Curriculum } \\
\text { implementers }\end{array}$ & $\begin{array}{c}0.128 \\
p=0.066 \\
N=208\end{array}$ & $\begin{array}{c}0.113 \\
p=0.102 \\
N=209\end{array}$ & $\begin{array}{c}0.183^{* *} \\
\mathrm{p}=0.008 \\
\mathrm{~N}=208\end{array}$ & $\begin{array}{c}0.236^{*} \\
p=0.006 \\
N=134\end{array}$ \\
\hline V157 - Principal & $\begin{array}{c}0.109 \\
p=0.119 \\
N=207\end{array}$ & $\begin{array}{c}0.175^{*} \\
p=0.012 \\
N=208\end{array}$ & $\begin{array}{c}0.096 \\
p=0.169 \\
N=207\end{array}$ & $\begin{array}{c}0.199 * \\
p=0.021 \\
N=134\end{array}$ \\
\hline V158 - HOD's & $\begin{array}{c}0.121 \\
p=0.084 \\
N=207\end{array}$ & $\begin{array}{c}0.171^{*} \\
p=0.013 \\
N=208\end{array}$ & $\begin{array}{c}0.123 \\
p=0.076 \\
N=208\end{array}$ & $\begin{array}{c}0.179 * \\
p=0.039 \\
N=133\end{array}$ \\
\hline V159 - Yourself & $\begin{array}{c}0.110 \\
p=0.112 \\
N=209\end{array}$ & $\begin{array}{c}0.086 \\
p=0.213 \\
N=210\end{array}$ & $\begin{array}{c}0.115 \\
p=0.099 \\
N=209\end{array}$ & $\begin{array}{c}0.167 \\
p=0.053 \\
N=135\end{array}$ \\
\hline
\end{tabular}

Note: ** Correlation is significant at the 0.01 level, * Correlation is significant at the 0.05 level.

\section{Professional development}

None of the staff development programs from the school, Department of Education, Teacher Unions or the MSSI, appear to have a significant affect on any of the sub-constructs. This is due to the very small number of teachers who attempted to answer this section of the questionnaire. Only five to twenty teachers answered this section.

\section{Change forces}

The C2005 documents (V130) and materials on C2005 from the Department of Education (V130) appear to have the most influence on the Profile of Implementation affecting all sub-constructs barring the teaching Science and 
Maths in Society. The support of teachers within the same school (V135) impact both Curriculum Implementation and Science and Maths in Society. Assessment is significantly affected by loyalty to the Principal or HOD (V137) and the support and encouragement of teachers from within the cluster (V138). Assessment seems most affected by change forces while Science and Maths in Society is least affected by the same.

\section{Monitoring and accountability}

Circuit managers appear to play the most prominent role in terms of monitoring and accountability. The Assessment sub-construct appears to only be affected by the Principal and the HOD. Science Practical work is the most sensitive to monitoring and accountability being significantly influenced by all monitors, except the self. In fact, the 'self' was the only monitor that did not significantly correlate with any of the sub-constructs.

\subsection{STEPWISE REGRESSIONS}

To learn more about the relationship between sets of Capacity to Innovate or Outside Influences items and Classroom Interaction, multiple stepwise regression analyses was carried out. Multiple stepwise regression is a procedure that determines which set of independent (predictor) variables, in this case the Capacity to Innovate items and the Outside Influences items, best correlate with the dependant variable, in this case one of four composite scores of the subconstructs of the Profile of Implementation.

In stepwise multiple regression, the number of predictor variables and their order of entry into the equation are decided statistically. The predictor variable with the highest correlation with the dependant variable is entered into the equation first. If the probability associated with the test of significance is less than or equal to the default 0.05 , the predictor variable is retained in the equation. The second predictor variable is selected based on the highest partial correlation. If it passes the entry requirement of PIN $=0.05$, it is also retained in the equation. Once the third predictor variable is considered for inclusion into the equation, those already accepted in the equation are examined for removal. If the POUT = 0.10 , for an included predictor variable, it is then removed. A predictor variable may enter the equation early in the process of adding predictors, but may 
become redundant as other predictors enter the model. The selection of predictor variables stops when no more variables meet the entry or removal requirements. The most important statistic in evaluating the model is the R-squared for the model. R-squared is the squared correlation coefficient between the dependant variable and the selected set of predictor variables. R-squared values range between 0 and 1 . The closer to 1 the R-squared value is, the greater the relationship between the set of predictors and the dependant variable. The Rsquared value is therefore the percent variance in the dependant variable explained jointly by the predictors selected for the model. Expressed alternatively, an R-squared value of 0.86 means that $86 \%$ of the variance in the dependant variable (the composite scores from the Profile of Implementation) can be explained by the set of predictor variables (from Capacity to Innovate and Outside Influences) included in the model.

The F-test is used to determine the significance of $\mathrm{R}^{2}$. By testing this significance the significance of the model as a whole is tested. If the probability of $\mathrm{F}<.05$, then the model is considered significantly better than would be expected by chance.

For each of the Profile of Implementation sub-constructs, two regression analyses were carried out. The first one was conducted using the Capacity to Innovate variables and the second one, the Outside Influences variables.

\subsubsection{Predicting Classroom Interaction}

A stepwise multiple regression on Classroom Interaction analysis yielded the model indicated in Table 7.6 below. Seven variables proved to be predictors of Classroom Interaction. The R-squared for this model is 0.459 . The R-squared value indicates that in this model, $45.9 \%$ of the variation in Classroom Interaction can be explained by seven predictors. The sample size was reduced to 65 . The F value of this model is $7.893(p=0.000)$.

A variety of resources and services (V114, V119, V94) and the collegial atmosphere between parents, teachers and the principal (V75, V84, V79) are all important for good Classroom Interaction. Teachers responded to V78, teachers reprimand learners for giving incorrect answers, in such a way that indicates that this practice is not very common. The absence therefore of this practice leads to positive classroom interaction. 
Table 7.6 Stepwise Multiple Regression model for Capacity to Innovate factors that predict Classroom Interaction

\begin{tabular}{|ccccc|}
\hline & \multicolumn{4}{c}{ Change statistics } \\
\cline { 2 - 5 } Model & R Square change & F Change & $d f$ & Sig. F Change \\
\hline 2 & 0.159 & 13.403 & 71 & 0.000 \\
\hline 3 & 0.060 & 5.419 & 70 & 0.023 \\
\hline 4 & 0.072 & 7.005 & 69 & 0.010 \\
\hline 5 & 0.055 & 5.744 & 68 & 0.019 \\
\hline 6 & 0.042 & 4.638 & 67 & 0.035 \\
\hline 7 & 0.035 & 3.994 & 66 & 0.050 \\
\hline & 0.036 & 4.313 & 65 & 0.042 \\
\hline
\end{tabular}

Note: Model 1. Predictor: V114, Model 2. Predictors: V114, V119, Model 3. Predictors: V114, V119, V94, Model 4. Predictors: V114, V119, V94, V78, Model 5. Predictors: V114, V119, V94, V78, V75, Model 6. Predictors: V114, V119, V94, V78, V75, V84, Model 7. Predictors: V114, V119, V94, V78, V75, V84, V79.

V114 - Availability of illustrated learning programs, V119 - Learners come from homes that have running water, V94 - Availability of science apparatus, V78 - Teachers reprimand learners for giving incorrect answers, V75 - Teachers in the circuit meet to plan lessons, V84 - Parents are actively involved in the school, V79 - The principal is supportive of the teachers.

Table 7.7 below shows the stepwise regression analysis of Classroom Interaction and Outside Factors. Only one variable proved to be a predictor of Classroom Interaction. The R-squared for this model is 0.087 . Therefore only $8.7 \%$ of the variation can be explained by the single variable.

Table 7.7 Stepwise Multiple Regression model for Outside Influences factors that predict Classroom Interaction

\begin{tabular}{lc|c|c|c|}
\multicolumn{5}{c}{ Change statistics } \\
\cline { 2 - 5 } Model & R Square change & F Change & $d f$ & Sig. F Change \\
\hline 1 & 0.087 & 7.923 & 83 & 0.006
\end{tabular}

Note: Model 1. Predictor: V157 - The Principal as a monitor of compliance with C2005.

The $\mathrm{F}$ value of this model is $7.923(\mathrm{p}=0.006)$.

\subsubsection{Predicting assessment}

A stepwise multiple regression on Assessment yielded the model indicated in Table 7.8 below. Only one variable proved to be a predictor of Classroom Interaction. The R-squared for this model is 0.095 once again indicating that this 
is a weak model, with only $9,5 \%$ of the variation in Assessment explained by the regression model with one predictor. However, the importance of the HOD support of teachers cannot be ignored as an important contributor to higher assessment practices. The F value of this model is $7.619(\mathrm{p}=0.007)$.

Table 7.8 Stepwise Multiple Regression model for Capacity to Innovate factors that predict Assessment practice

\begin{tabular}{lcccc}
\multicolumn{5}{c}{ Change statistics } \\
Model & R Square change & F Change & $d f$ & Sig. F Change \\
1 & 0.095 & 7.619 & 73 & 0.007
\end{tabular}

Note: Model 1. Predictor: V80 - Support from the Head of Department.

In table 7.9, the stepwise regression model for Assessment using variables from Outside Influences is shown. Three variables were shown to be predictors of Assessment. The R-squared value for this model is 0.171 , indicating that $17.1 \%$ of the variation in assessment is predicted by three variables. The $F$ value of this model is $5.534(\mathrm{p}=0.002)$.

Table 7.9 Stepwise Multiple Regression model for Outside Influences factors that predict Assessment practice

\begin{tabular}{lcccc} 
& \multicolumn{4}{c}{ Change statistics } \\
Model & R Square change & F Change & $d f$ & Sig. F Change \\
\hline 1 & 0.081 & 7.285 & 83 & 0.008 \\
2 & 0.043 & 3.982 & 82 & 0.049 \\
3 & 0.047 & 4.569 & 81 & 0.036 \\
& Total R-square & & & \\
& $=0.171$ & & & \\
& & &
\end{tabular}

Note: Model 1 Predictor: V157, Model 2 Predictors: V157, V145, Model 3 Predictors: V157, V145, V135.

V157 - The Principal as a monitor of compliance with C2005, V145 - The effect of teacher union run workshops, V135 - The support of teachers within the school as an effect on willingness to implement C2005.

The Principal's authority as a monitor of compliance is an important variable in assessment practices, along with the support of teachers within the same school. Interestingly, teachers perceive the effect of teacher union run workshops to be important but only 7 teachers responded that they had attended teacher union run workshops. 


\subsubsection{Predicting the teaching of Science and Mathematics in Society}

A stepwise multiple regression on the teaching of Science and Mathematics in Society yielded the model indicated in Table 7.10 below. Four variables proved to be predictors. The R-squared for this model is 0.256 indicating that the variables in the model predict $25,6 \%$ of the variation in teaching science and mathematics in society. The $F$ value of this model is $6.031(p=0.000)$.

Table 7.10 Stepwise Multiple Regression model for Capacity to Innovate factors that predict the teaching of Science and Mathematics in Society

\begin{tabular}{lcccc} 
& \multicolumn{4}{c}{ Change statistics } \\
Model & R Square change & F Change & $d f$ & Sig. F Change \\
\hline 1 & 0.092 & 7.433 & 73 & 0.008 \\
\hline 2 & 0.067 & 5.763 & 72 & 0.019 \\
\hline 3 & 0.052 & 4.676 & 71 & 0.034 \\
\hline 4 & 0.045 & 4.206 & 70 & 0.044 \\
\hline & Total R-squared & & & \\
\end{tabular}

$$
=0.256
$$

Note: Model 1. Predictor: V88, Model 2. Predictors: V88, V121, Model 3. Predictors: Model 4. Predictors: 88, V121, V101, V75.

V88 - Learners are in class as scheduled, V121 - The parents or guardians of the learners have at least a matric education, V101 - The perceived effect of having photocopying facilities available, V75 Teachers within the circuit meet with each other to plan lessons.

'Learners being in class as scheduled' is indicative of discipline and a good work ethic. This along with parent/guardian education and collegiality among teachers within the circuit are important predictors for the incorporation of science and maths in society in teaching. Only one resource, that of photocopying facilities appears to be important.

Table 7.11 shows the stepwise regression model for the variables from the construct Outside Influences and the composite score for Science and Maths in Society. The F value of this model is $8.306(p=0.000)$.

Inputs from Curriculum Implementers and Circuit Managers are important in the teaching of science and mathematics in Society. Again, the teacher's perceived effect of trade union run workshops appears to be a valuable contributor. 
Table 7.11 Stepwise Multiple Regression model for Outside Influences factors that predict the teaching of Science and Mathematics in Society

\begin{tabular}{lcccc} 
Model & \multicolumn{4}{c}{ Change statistics } \\
\hline 1 & R Square change & F Change & $d f$ & Sig. F Change \\
\hline 2 & 0.128 & 12.057 & 82 & 0.001 \\
3 & 0.069 & 6.929 & 81 & 0.010 \\
& 0.041 & 4.262 & 80 & 0.042 \\
& $\begin{array}{c}\text { Total R-squared } \\
=0.238\end{array}$ & & & \\
& & & &
\end{tabular}

Note: a. Predictor: V145, b. Predictor: V145, V131, c. Predictor: V145, V131, V133.

V145 - The effect of teacher union run workshops, V131 - Pressure from circuit managers as an effect on willingness to implement C2005, V133 - Support and encouragement from Curriculum Implementers as an effect on willingness to implement C2005.

\subsubsection{Predicting Science Practical Work}

A stepwise multiple regression on Science Practical Work and Capacity to Innovate yielded the model indicated in Table 7.12 below. Six variables proved to be predictors of Science Practical Work. The R-squared for this model is 0.648. The F value of this model is $11.979(p=0.000)$.

Table 7.12 Stepwise Multiple Regression model for Capacity to Innovate factors that predict the teaching of Science Practical work

\begin{tabular}{|c|c|c|c|c|}
\hline \multirow[b]{2}{*}{ Model } & \multicolumn{4}{|c|}{ Change statistics } \\
\hline & $R$ Square change & F Change & $d f$ & Sig. F Change \\
\hline 1 & 0.307 & 19.499 & 44 & 0.000 \\
\hline 2 & 0.095 & 6.848 & 43 & 0.012 \\
\hline 3 & 0.083 & 6.810 & 42 & 0.013 \\
\hline 4 & 0.056 & 4.988 & 41 & 0.031 \\
\hline 5 & 0.054 & 5.346 & 40 & 0.026 \\
\hline 6 & 0.053 & 5.847 & 39 & 0.020 \\
\hline & $\begin{array}{c}\text { Total R-squared } \\
=0.648\end{array}$ & & & \\
\hline
\end{tabular}

Note: Model 1. Predictor: V114, Model 2. Predictors: V114, V120, Model 3. Predictors: V114, V120, V82, Model 4. Predictors: V114, V120, V82, V128, Model 5. Predictors: V114, V120, V82, V128, V77, Model 6. Predictors: V114, V120, V82, V128, V77, V108.

V114 - The availability of illustrated learning programs, V120 - Learners live in a safe neighbourhood, V82 - Learners have a say in the running of the school, V128 - Learners find science easy, V77 - Teachers at the school are often not in their classrooms when they should be, V108 - Availability of a library. 
This is the strongest model in the study, although the sample size was reduced to 39 , showing that $64.8 \%$ of the variation in the quality of science practical work can be predicted by six variables. The variety of the variables, from resources to learner factors, shows the complex nature teaching science practical work. Teachers responded to V77 in such a way that indicates that this practice is not very common. The absence therefore of this practice, i.e. teachers are actually in their classes during the scheduled times, correlates with better science practical work.

No Stepwise Multiple Regression model for Outside Influencing factors that predict the teaching of Science and Mathematics could be created. It therefore appears that none of the Outside Influences variables are important predictors of Science Practical Work.

\subsection{SUMMARY}

Summaries of the relationships between the four composite scores from the Profile of Implementation and the Capacity to Innovate and Outside Factors variables are summarised separately below.

\subsubsection{Capacity to Innovate relationships}

From the correlation tables, some interesting findings have come to light. Among the teacher factors, there appear to be several that correlate with the four Profile of Implementation composite scores. However, only two of the factors appear in the model for Classroom Interaction and no others appear in the models for the other three sub-constructs. V75 (In my circuit teachers meet each other to plan lessons) correlates with all four of the Profile of Implementation composite scores and appears in the model for Classroom Interaction. V78 (In my school teachers reprimand learners for providing incorrect answers e.g. by calling then stupid) also features in the model but does not correlate significantly with any of the composite scores.

Among the learner factors, only three variables correlated with any of the composite scores. These included V121 (The parents or guardians of my learners have a matric or higher certificate), V126 (My learners are proficient in the language of instruction) and V128 (My learners find science easy). V121 was kept 
in the model predicting the teaching of science and maths in society and V128 was kept in the model for science practical work. However, three other learner factors proved to be predictors in other models. V119 (Learners come from homes that have running water) features in the model for Classroom Interaction. V120 (Learners live in a safe neighbourhood) is kept in the science practical work model. Two out of six predictors for science practical work come from learner factors.

Science practical work appears to be most influenced by physical resources, with eight physical resources correlating with the science practical work composite. None of the physical resources correlated with the science and maths in society composite. In the correlation table, V114 (availability of illustrated learning programs) correlates significantly with only the science practical work composite. However, this variable is retained as a strong predictor in two models, those of Classroom Interaction and Science Practical Work. V94 (Science apparatus) was not part of the Science Practical work model but was included in the Classroom Interaction model. It showed no significant correlations in the correlation table. V101 (the perceived effect of having copier facilities available) was included in the model for Science and Maths in Society whereas it did not show any significant correlation with Science and Maths in Society.

In terms of School Ecology and Management, only two variables showed no significant correlations with any of the four composite scores. However, only four of the variables proved to be predictors. V80 (Support from the HOD) was the only predictor for Assessment and also correlates strongly with the Assessment composite score. V82 (Learners have a say in the running of the school) is a predictor in the Science Practical Work model but also correlates strongly with Science and Maths in Society. V84 (Parents are actively involved in the school) is a late entering predictor in the Classroom Interaction model and correlates with all the composite scores. V88 (Learners are in class as scheduled) is a strong predictor for Science and Maths in Society but correlates well with Classroom Interaction too.

\subsubsection{Outside Influences}

Only one Professional Development variable appeared as a predictor. V145 (the perceived effect of teacher union workshops) was retained as a predictor in the models for Assessment Practice and Science and Maths in Society. Similarly only 
one variable from amongst the Monitoring and Accountability variables (V157 the principal as a monitor of change) was retained as a predictor. It was kept in the models for Assessment Practice as well as being the only predictor in the model for Classroom Interaction.

Among the Change forces, three variables proved to be predictors. For the Classroom Interaction and Science Practical Work composites, no change forces were retained as predictors. V131 (pressure from circuit managers as an effect on willingness to implement C2005) and V133 (support and encouragement from curriculum implementers as an effect on willingness to implement C2005) are two of the three predictors for Science and Maths in Society. Interestingly, V131 and V133 do not correlate significantly with any of the composite scores. V135 (the support of teachers in the school as an effect on willingness to implement C2005) is retained as the last of the three predictors in the model for Assessment. Again interestingly, a significant correlation exists between V135 and Classroom Interaction and Science and Maths in Society, but not for Assessment.

It is interesting to note that for Classroom Interaction, Science and Maths in Society and Science Practical work, Capacity to Innovate variables provide more predictors than Outside Influences. In fact the Outside Influences variables are totally absent from the model for Science Practical Work. For Assessment it is the Outside Influences that provide more predictors. 


\section{CHAPTER 8 \\ Discussion}

In this final chapter the findings of the study are discussed. After a recapitulation of the research focus and method (8.1), the main results are summarized (8.2). These results are discussed in section 8.3 , and a reflection on the research approach is included in section 8.4. In sections 8.5 and 8.6 recommendations are formulated and conclusions are drawn.

\subsection{RECAPITULATION OF THE RESEARCH PROBLEM AND APPROACH}

South Africa underwent major political changes in 1994. The education system that was in place under white rule had to be replaced as quickly as possible to ensure equal education for all South African citizens as soon as democracy came into being. Within weeks of the new government coming into power, the first changes in the curriculum were made. These were cosmetic changes to the existing curriculum, cleansing it of any content that could be seen as prejudicial and unique to the apartheid curriculum.

However, these cosmetic changes were not enough to ensure a truly new identity for education. A curriculum had to be formulated based on a new philosophy. Not only was new content selected for the curriculum, but a new methodology in teaching based on OBE. The new curriculum was called C2005, as it was intended that it would be completely implemented across the twelve years of schooling in 2005.

To many teachers, C2005 and OBE presented a radical departure from their previous teaching practices. There were a few who avoided this quandary by interpreting $\mathrm{OBE}$ as a synonym for what they had been doing all the time. What was common across the board was confusion about C2005. The curriculum documents abounded with new terminology that was unfamiliar to those who 
were to implement the curriculum, including teachers and departmental leaders. It was clear that the teachers would need extensive in-service training in order to master the new curriculum. However, the trainers were often not familiar with the complexity of the curriculum themselves, so very little progress was initially made in mastering the new curriculum and the Department of Education came under much criticism.

The National Department of Education realised that C2005 had to be revised. After open and broad consultation with specialists and interested and affected parties, the Revised National Curriculum Statements were introduced. While still called C2005, and with OBE remaining the central tenet, the revised version was simpler and easier to implement.

The study reported in this thesis took place during the period in which C2005 was being revised. It had been clear before the study started, that C2005 implementation had been problematical. At the time, the MSSI supported schools in the Mpumalanga province of South Africa through a cascade model of inservice training of teachers to assist in C2005 implementation in mathematics and science. Its aim was the improvement of mathematics and science teaching which in turn would lead to improved skills among learners in these subjects. In collaboration with MSSI specialists from Japan, staff from the Science Education Centre at the University of Pretoria assisted in the in service training, ensuring that the directives of C2005 were being included.

In order to monitor the progress of the MSSI, surveys were conducted among teachers from 2001 to 2003 . The surveys were altered each year in order to gain a better understanding of what was happening in the classrooms at the time in terms of progress in C2005 implementation as well as trying to diagnose any obstacles to the progress in implementation. During the time the surveys were being carried out, Rogan and Grayson developed a framework that they hoped could be used in developing countries to assist in implementing new curricula. The survey questionnaire evolved along with the framework and in 2003, the questionnaire was completely aligned with the Rogan-Grayson framework. The questionnaire data from the 2003 questionnaire are analyzed in this dissertation and are reported in terms of the constructs and the sub-constructs of the framework. 
In 2002, when the second questionnaire was sent out, a subset of schools was selected to obtain observed data. There had been a call from academics involved in the MSSI to collect case study data which could then be compared to the outcome of all self-reported data. The protocol for the case studies was designed to be in line with the Rogan-Grayson framework. This would permit data from the questionnaires to be directly comparable to data from the case studies. The data from the 2002 case studies were used to support the data from the 2003 questionnaire in this dissertation.

\subsection{SUMMARY OF THE MAIN FINDINGS}

This dissertation had two focus areas. The first was to capture a picture of what the situation in Mpumalanga schools was in terms of the three constructs in the Rogan-Grayson framework. Descriptive analyses were carried out for this purpose and case study reports were used in support of the questionnaire data. The second research focus was to find relationships between variables from the constructs that could possibly predict classroom performance. For this focus, stepwise multiple regression analyses were carried out for the variables from the constructs Capacity to Innovate and Outside Influences and the composite scores for the sub-constructs Classroom Interaction, Assessment, Science and Maths in Society and Science Practical work. The aim of carrying out these analyses was to attempt to find variables that might predict the performances described in the Profile of Implementation. The results are summarized below under the headings of each of the constructs of the Rogan-Grayson Framework.

\subsubsection{Profile of Implementation}

Results of the Spearman's correlations and stepwise multiple regressions are discussed below for each of the sub-constructs of the Profile of Implementation viz classroom interaction, assessment, science and maths in society and science practical work.

\section{Classroom interaction}

For Classroom Interaction, which reflects classroom practice, it appears that in the majority of classrooms most of the classroom practice is still at Level 1, indicating slow progress towards the ideals of C2005. Level 2 practices are 
beginning to take place and Level 3 practices only rarely are seen. These findings from the statistical analysis of the questionnaire are supported by the findings of the case studies. However, the case studies showed that in some classrooms, even Level 1 practice were not yet achieved.

There were several variables from both Capacity to Innovate as well as Outside Influences that predict the Classroom Interaction score, however most of the predictors came from the construct Capacity to Innovate. On closer inspection it can be observed that the majority of the correlating factors come from within the broad school community, including everyone from parents, to learners, teachers from schools in the clusters, their leadership within the school, and the leadership from within the Department of Education. Other important factors include some learner factors and resources.

There were seven predictors from Capacity to Innovate and only one from Outside Influences that predict Classroom Interaction. The seven predictors from Capacity to Innovate came out of learner resources, learner factors, physical resources, teacher factors and school ecology and management - all the areas of the sub-construct Capacity to Innovate. Only the principal as a monitor of compliance with C2005 out of the Monitoring and Accountability area of Outside Influences proved to be a predictor. Surprisingly, no predictors came out of the Professional Development area of Outside Influences.

\section{Assessment}

With regard to assessment, it seems that more progress has been made with mostly Level 2 practices occurring in many classrooms. It appears from the survey data that Level 3 and Level 4 practices exist, but the case studies indicate that this is an over-representation. The case-study data show rather that practices are more Level 1 orientated than Level 2 orientated, but that there is an effort to move towards Level 2 practices.

Most of the variables that impact Assessment come from Outside Influences. Capacity to Innovate seems to have little to do with Assessment practice. Only one predictor came out of Capacity to Innovate (from the area of School Ecology and Management) to predict Assessment while three (one from Monitoring and Accountability and two from Professional Development) predictors came out of Outside Influences. 
Good relations between colleagues within and from immediately outside the schools appear to be important for good Assessment practice. The three predictors for improved Assessment Practice have to do with support from and monitoring by colleagues within the school. The support given by the HOD and other teachers within the school as well as the principal in his role as a monitor of change all predict better assessment practice.

Several other variables predict improved Assessment practice. It appears that healthy relationships with all the role players in a school are important to ensure better Assessment practice. Involvement with teachers from other schools in the circuits and clusters further impacts on better Assessment practice. This interaction can take the form of lesson planning together, encouraging and supporting one another.

In terms of resources, C2005 documents and materials from the Department of Education are important. The C2005 material from the Department is perceived as authoritative and is used as well trusted guidelines. Learner textbooks are also predictors, providing material and ideas for assessment tasks and questions from the textbooks are exemplary for new questions.

Three Learner Factors correlated with good Assessment practice. Two of these factors can be linked with learner socio-economic status. It is difficult to explain this relationship and the one between Assessment and learners finding science easy.

\section{Science and Maths in Society}

From levels 1 to 4 there is a slight decrease in the frequency of use of the practices given in the questionnaire data. However, the reality is somewhat different. No level three or four practices were observed in any of the case studies. A variety of variables from Capacity to Innovate and Outside Influences impact the inclusion of teaching of science and maths in society. This approach in teaching is novel for most teachers and many of them require assistance in being able to incorporate societal issues effectively. Currently it appears that pressure from above is the most important factor influencing the incorporation of societal issues. Curriculum implementers and circuit managers are influential in supporting and monitoring this process. The collegiality shared in circuit meetings provides positive inputs too. General discipline seems to play a role with learners and teachers being in class as scheduled and extra-mural activities not interfering with classroom activities. 
Science and Maths in Society was predicted by four variables from Capacity to Innovate and three variables from Outside Influences. The predictors from Capacity to Innovate came from across the spectrum of areas within Capacity to Innovate with one predictor each coming from the areas School Ecology and Management, Learner Factors, Physical Resources and Teacher Factors. The three predictors from Outside Influences came from Professional Development only.

\section{Science Practical work}

Most of the practical work carried out in schools is still heading towards level 1 practice or is reported to be at level 1. Some schools report using level 2 practices, but these kinds of practices were not observed in the cases studies. It is likely that the results reported in the questionnaire are inflated. Level 4 practices are reported to occur, but at low frequencies.

An unexpected selection of variables from the Capacity to Innovate predicts science practical work with most of them having to do with the learners. Outside influences did not provide any predicting variables. Learners having a say in the running of the school and coming from homes in safe neighbourhoods with running water which indicate a level of socio-economic status, are predictors that do not make much sense. However, the fact that learners find science easy predicts science practical work and there is a reason for this. If learners experience science practical work, it is likely that they will understand science better as they have a more complete science learning experience.

Other variables that correlate mainly have to do with resources and support from the school community. The required resources include C2005 documents and materials from the Department of Education. These provide the guidelines and direction for science practical work. In addition apparatus, illustrated learning programs, text books and a library are important.

\subsubsection{Capacity to Innovate}

Teachers were generally found to have positive morale. There is reported to be a good collegiality among teachers as they discuss and share amongst themselves issues pertaining to their teaching both within the school and within the circuit. The case study data supported these findings. It appears therefore from the teachers' point of view, that there are no serious problems in terms of teacher factors with regards to their capacity to implement new innovation. 
It emerges from the case study data as well as the questionnaire data that school ethos and management in the schools of Mpumalanga support innovation. The principals and HOD's provide a supportive environment and the teachers feel that they are part of the school. It appears too that good levels of discipline are maintained in most cases.

In terms of the supply of physical resources, shortages do appear. Fewer than half the schools have maths apparatus, a laboratory and a library - three resources generally considered important for good science and maths teaching. It is interesting to note however, that there does not seem to be a serious shortage in the supply of science apparatus. During the cases studies it was observed that many schools had well equipped laboratories that were not used. In some cases that apparatus was stored in their original packaging, never having been opened. NGOs have over the years provided many resources, particularly lab equipment, to under-privileged schools but have not provided that accompanying training required to use the resources. This has resulted in the current situation where the presence of science apparatus in the school cannot be used to predict science practical work.

Although the majority of schools have running water and electricity, some schools were still without these facilities. The case studies showed that in some schools only a single tap was available. Teachers from such schools would have answered on their questionnaires that running water was available. The adequacy of the running water was not questioned in the instrument. Teachers were also asked about their perceptions about how important the individual resources were. To them electricity, photocopying facilities and running water were the most important. Learner resources were also investigated. In more than half the schools, few or no learners had a place to study after school. In fewer than half the schools could it be said that most or almost all learners had their own textbooks.

The questions on learner factors rendered a diversity of situations throughout the province. This diversity was again supported by the findings of the case studies. Many of the learners in Mpumalanga are affected by poverty. Some learners arrive at school hungry and come from homes without running water or electricity. Few parents or guardians are well educated and family duties often keep some learners out of school. Several learners are old for their grades having repeated at least one year of school. The proficiency in the language of instruction by the learners is generally poor, with less than twenty percent of the teachers 
reporting that most or all of their learners are proficient in the language of instruction. The majority of learners do not find maths and science easy to learn. The case studies reported that some children only attend the first session of school in the day, not returning to school after the lunch break.

\subsubsection{Outside Influences}

C2005 documents and materials on Curriculum 2005 from the Department of Education appear to be most influential on teachers in their implementing C2005. These two influences correlate with all but the Science and Maths in Society sub-constructs. The sub-construct Assessment is influenced by the teachers' loyalty to the principal or HOD as well as support from teachers within the same cluster in addition to the C2005 documentation and Department of Education Documents on C2005.

Circuit managers appear to be the most important source of monitoring the uptake of C2005. All the other agents for Monitoring and Accountability also correlated with at least two of the Profile of Implementation composite scores, except self monitoring. It appears that Science Practical Work was the most influenced by agents of Monitoring and Accountability with all the agents except for the teacher themselves having an influence.

\subsubsection{Influential variables on implementation}

The variables from Capacity to Innovate and Outside Influences that were shown to predict and that correlated with the Profile of Implementation variables fall into two distinct groups: factors that the school system can affect, and those that it cannot realistically be expected to change. Those variables that the school can have an influence on include relationships between all the school community including parents, learners, teachers, leaders within the school and leaders within the education department. A common focus from all these parties along with a positive attitude and sound work ethics have been shown to be important factors in the Profile of Implementation. These factors are labeled below as the School Community in section 8.3. Those factors that the school system would have difficult in affecting are those to do with the socio-economic status of the community in which the school finds itself. Schools in indigent communities will often be under-resourced. An under-resourced school will have more difficulty in implementing innovation than others that are better funded by their communities. 


\subsection{DISCUSSION OF THE FINDINGS}

When all the predictors and variables that correlate with the sub-constructs of the Profile of Implementation are considered as a group, most of them fall into one of two groups viz. School Community (a broader category that School Ecology and Management - one of the sub-constructs of Capacity to Innovate) and socio-economic circumstances.

\subsubsection{School Community}

School Community includes variables that measure all the relationships between the Profile of Implementation variables and all the role players in the school community including the learners, parents, teachers, the school leadership in the form of HOD's, principals, circuit managers and curriculum implementers. It also includes teachers from schools in other districts or clusters.

The majority of the predictor variables and several other significantly correlating variables in one way or another fall within the ambit of the school community. These findings concur to a large degree with those of Hopkins and Harris (1997) who discerned six conditions required for successful uptake of an innovation in their studies of the IQEA project in several countries. Without developing these conditions within schools, the likelihood of success in implementation of an innovation is reduced. These conditions include

- practical efforts to include the community, learners and staff in policy decisions

- transformational leadership approaches

- effective coordination strategies

- proper attention to the potential benefits of enquiry and reflectio

- a commitment to collaborative planning and

- a commitment to staff development

The findings of this study are discussed below within the framework of some of the six conditions found to be appropriate. Additional conditions have been added that were not included in the Hopkins and Harris model, but were found to be important. 
Inclusion of the community, learners and staff in policy decisions

Several variables indicating the merits of including the parents, learners and staff in influencing the policy of the school were shown by our study to predict or correlate with successful C2005 implementation. This finding indicates that in Mpumalanga, like in other countries in the world, commitment to a common purpose by everyone involved with a school is an important pre- and co-requisite to curriculum implementation. This requirement is also found in Fullan's (1983) framework where his construct 'district and school factors' covers the relationships between parents and the school, teachers, their leaders within the school and the leaders in the Education Department. Similarly Zucker et al's (1998) model implies that teachers, the school and the community all impact on the classroom experience which in turn impacts on learner outcomes.

Literature based on smaller studies support these findings further. Parental involvement has been linked to learner success in the literature (Comer, 1984; Epstein \& Dauber, 1991). Epstein (1986) defines several types of parental involvement important in schooling which include parent involvement in governance and decision making. Thomson and Gunter (2006) cite several studies where it was found that it is important to involve learners about learning and teaching practices (Rudduck, 1996; Arnot et al., 2003). They also suggested that learners can be consulted on other areas of governance such as what is needed for improvement (Rudduck et al.,1996; Flutter \& Rudduck, 2004; Rudduck \& Flutter, $2004 a, b, c)$.

When it comes to staff participating in the management of the school, one must be careful in defining areas where shared decision making is appropriate and those where the leadership of the principal must take precedence. Weiss and Cambone (1994) investigated curriculum reform within schools where there was a shared decision making structure and in schools where there was not. They found that in schools where there was shared decision making, little progress was made towards progress in curriculum reform. However, in schools where there was no shared decision making structure curriculum reform made some progress. They suggest that school governance and policy issues such as classroom curriculum and instruction be uncoupled when it comes to shared decision making. Shared decision making on day to day school governance is important in gaining consensus amongst all staff. However, in areas of policy such as curriculum reform the decision for implementation is made by the authorities. 
Leithwood (1992) discerns two 'orders' of change that school leaders focus on. They are the first-order practices that include improving the technical instructional activities of the school through monitoring of teacher and learner classroom work and second-order activities such as building a shared vision, improving communication and developing collaborative decision making process. Weiss and Cambone would suggest that these first order practices be left to the leadership of the principal and that the second order practices become part of a consensual shared decision making base.

Building a shared vision for the school appears from our study to be a very important element in improving the profile of implementation. Leithwood places the building of the shared vision as one the second-order duties of a school leader. The outcome of a shared vision for the school is explained by Sarason (1990):

'...when a process makes people feel that they have a voice in matters that affect them, they will have greater commitment to the overall enterprise and will take greater responsibility for what happens to the enterprise.' (p61)

\section{Transformational leadership approaches}

The leadership within the school is shown by the analysis to be important in curriculum implementation in Mpumalanga. The importance of support as well as monitoring and guidance given to teachers by their compliment of leaders from HOD's to principals to circuit managers and curriculum implementers is illustrated by the variables measuring these relationships being predictors of curriculum implementation in the stepwise multiple regression. Other variables that correlated also supported this important factor in the success of curriculum implementation. The response of loyalty to the leadership is also shown by the data to impact on curriculum change.

The Malcolm et al (2000) study found that successful schools were those where there was a visible ethos of learning and working together towards a shared vision. This atmosphere had been chiefly attributed to the work of the principal. The teachers, learners and parents would then adopt this ethic and perpetuate it. Included in Fullan's and Pomfret's (1977) construct 'Characteristics of the School' the support of these leaders is also considered important, but their role in actively bringing about change and monitoring the change is not considered. Zucker et als model also acknowledges the importance of support only. 
In Mpumalanga it appears therefore that more than support is required by the education leadership. The leadership must play an active role in pushing for change as well as supporting the teachers to enable them to carry out the directives for change. In order to do this successfully, leaders need to have skills. However, several studies (Van der Westhuizen et al, 2004) indicate that principals have not been adequately trained for their roles of managing and leading schools and are not adequately qualified for the post of manager. However, in his study which investigated leaders' perceptions of the adequacy of the training they received for C2005 implementation, he found that principals and district managers reported that they were satisfied with the training they had received. If the leaders are unskilled, and report that they are happy with their training, it would appear that the principals do not yet know what is expected of them and that the training is not directed towards the skills that will make them successful change agents.

\section{Commitment to collaborative planning}

Collaborative planning and peer feedback were shown in our study to be beneficial for curriculum change in Mpumalanga as has been indicated by Fullan and Pomfret (1977) previously in other international studies. Their second construct, 'strategies and tactics used to bring about the implementation' includes teacher-teacher interactions as important forums for problem solving during implementation.

According to Hopkins et al (1998),

'...teacher development takes place most effectively in a school where there is a culture of collaboration. Working with a colleague not only dispels feelings of professional isolation but also assists in enhancing practice.' (p132)

Wenger (1998) defines groups where this type of collegial interaction takes place more formally as communities of practice. Communities of Practice develop around issues or practices that are of mutual interest to a group of practitioners. According to Wenger, a community of practice defines itself along three dimensions: 
- What it is about: Its joint enterprise as understood and continually renegotiated by its members.

- How it functions: Mutual engagement that bind members together into a social entity.

- What capability it has produced: The shared repertoire of communal resources (routines, sensibilities, artifacts, vocabulary, styles, etc.) that members have developed over time.

A community of practice for teachers would provide them with a forum in which to share and build up communal resources, engage with each other regarding curriculum implementation issues amongst others, and will grow informally and organically as the needs of the members of the community changes. Teachers who are struggling with curriculum issues are likely to benefit greatly from being part of such a community of practice. Clune (1998, p. 1) points out that "inservice professional development was seen as depending on active networks of teachers organized from the grassroots."

A community of practice can also provide a forum in which kenkyujugyo or lesson study or might be exercised. Lesson study is a Japanese approach to examining teaching practice where groups of teachers discuss lessons that they have planned together and observed. This method of teaching analysis has been seen by many educators as a promising form of professional development and a powerful tool for continuous improvement. (Fernandez, 2002). The MSSI made tentative steps towards using this approach in Mpumalanga, by inviting CIs and cluster leaders to write lesson plans together. It was intended that these lessons be shared with teachers at workshops and then used in the classroom (Ono et al, 2007).

Howie (2002) states that in South Africa 83\% of principals report that there is a policy in place regarding promoting co-operation and collaboration among teachers. The principals report that teachers do share and meet regularly to discuss instructional goals and issues. Teachers are better able to implement new practices within the context of supportive collegial relationships (Hopkins, 1990). The feeling of being part of a professional group enables teachers to continue to improve their own teaching. They have in the collaborative planning sessions an opportunity for discourse about teaching and curriculum related issues. It is here that concerns about teaching can be discussed and solutions to implementation problems brought about through sharing. 


\section{Commitment to staff development}

In the questionnaires we asked about the sources of professional development that teachers were exposed to in an effort to discern which interventions were effective and which ones were not. What was not anticipated was the low numbers of teachers that were offered the different types of professional development. The low response frequency to these items made the data unusable. It was evident, however, from the case studies that teachers had been receiving short workshop training sessions on various aspects of C2005 and that these were inadequate and in many cases confused the teachers more than assisted them.

In many of the ex-DET schools in South Africa, teacher subject knowledge is a very sensitive issue. The old DET teacher training provided limited subject knowledge, and many teachers still in practice today have poor subject knowledge as a consequence. Teacher subject knowledge was not interrogated in the questionnaire study, but from the case-studies, it was seen that their pedagogical content knowledge was poor.

\section{Functional schools}

In the models for curriculum implementation drawn up in developed countries, it has not been seen as necessary to look at the level of functioning of the schools. Although their have been categorization schemes for schools of different capacities to implement change, implementation models have mostly been one-size-fits -all. This strategy has been adequate in developed schools because it can be safely assumed that most schools have an acceptable minimum standard e.g. a timetable is followed and teachers and learners are in the classrooms as scheduled. However, in South Africa, as a result of the separate development of school systems in the apartheid era, there is a vast variety of schools from those below the Type 1 schools of Hopkins to sophisticated private schools that could compete with internationally renowned schools such as Eton or Harrow in the UK.

Among the indicators of a functioning school would be work ethic related discipline. Hopkins et al (1998) touch briefly on the establishment of rules and boundaries in the classroom for successful learning and teaching, but do not address the discipline of the teacher directly. This factor does not find a place in any of the exemplary models referred to in this study, but emerges from our data as being a significant factor in the success of curriculum implementation. Work 
ethic related variables included those for teachers and learners and it was found that in both cases work discipline is important.

\section{Education level of parents}

Another factor that occurs in our study and in none of the other models or frameworks we have referenced is the education of the parents. While in many Western countries it can be assumed that there is a certain level of education amongst the parents of learners, in South Africa this is not the case. As mentioned under Inclusion of the community, learners and staff in policy decisions, parental involvement is important in many facets of the child's education. Howie (2002) states that parental education is often linked to learner achievement and found in her study that learners whose parents completed secondary school achieved higher scores in the TIMMS study than those whose parent did not complete their schooling (in South Africa and Internationally). Many parents and guardians in rural South Africa are illiterate and have had very limited education or in some cases no formal education at all. Most do not have a school exit certificate. The fact that parents' or guardians' education correlated with elements from the profile of implementation tells that in South Africa we have a long way to go in improving education for all before high level teaching practices can be achieved. It is likely to take several generations before we in South Africa can make the same assumptions about the base-line education of adults that is made in the developed world. Parent education is also related to socio-economic status and is referred to again below.

\section{Learner language proficiency}

Another anomaly is that from the data, it can be observed that learner proficiency in the language of instruction did not come out as a strong predictor for any of the sub-constructs of the Profile of Implementation. It correlates significantly with Classroom Interaction and Science Practical Work only. Howie (2002) found that in Mpumalanga the mean English language proficiency scores attained by learners in the Third International Mathematics and Science Study was 15.64 out of 40, indicating that in Mpumalanga, learners have a poor proficiency in English. Those learners in her study who spoke African languages struggled more in the TIMMS test than the white children who speak either English or Afrikaans as a first language. Howie states that "...the fact that some pupils never have the opportunity to speak English at home has a negative impact on their proficiency in that language." (p121). 
There is much literature and much debate about the merits of mother tongue education and problems associated with learning in a language other than the mother tongue. It must be remembered that in South Africa by the time a learner has reached grade 8 , the lowest grade cohort studied in this thesis, s/he has supposedly been learning in English for at least four years. Mother tongue education is offered only up to Grade 4. It was observed in the case studies too that although teachers used English materials and spoke English in the classrooms, they did speak in the vernacular at times to explain concepts.

\subsubsection{Socio-economic Circumstances}

Socio-economic circumstance has been extensively studied in relation to achievement, with some studies finding a positive effect, and others finding it has no effect. In a large scale study in the US Scantlebury et al (2001) investigated the effects of the class, home and peer environments on learner achievement. They found that all three environments played a role in learner attitudes, but only the classroom environment affected student achievement. Hewson et al (2001) found that the culture and climate of schools differentially affects their progress towards reform. Supovitz and Turner (2000) found that school socio-economic status was found to influence practice more substantially than either principal supportiveness or available resources.

It was not a focus of the questionnaire to interrogate the learner socio-economic status as almost all the schools were in areas populated by mainly impoverished communities. However, some variables that were predictors showed that the even small variations in the socio-economic status within a community do have an impact on the Profile of Implementation. The provision of basic services such as water and electricity to the community are indicators of socio-economic status which in turn influences what happens in schools. Howie (2002) reported that $28 \%$ of learners in South Africa lived in homes where there was no electricity and $39 \%$ in homes that did not have running water. In her findings she reports that socio-economic status is a significant factor in learner achievement.

The type of home that the learner comes from also has an impact on curriculum implementation. A place to study after school in the home and the security of the neighborhood are important factors in curriculum implementation. Feeding schemes play a role and curriculum implementation. This means that the learners 
need to be well nourished in order for curriculum implementation to take place. Feeding schemes occur in schools where there is enough financial backing to supply poorer children in the school with food. Very poor schools cannot afford feeding schemes and so many of their learners will remain hungry. Where feeding schemes do occur it appears that curriculum implementation proceeds better.

Another factor which affects implementation is the supplier of textbooks to teach learner. Textbooks are usually supplied by the Department of Education. However, in some schools in South Africa, usually private schools or ex-model C parents are expected to purchase the textbooks for their children. The department of education does not supply adequate numbers of textbooks to all schools and parents in the poor communities in which the study took place are not in a financial position to buy textbooks for their children. The lack of textbooks therefore impedes a proficient curriculum implementation.

\subsection{REFLECTIONS ON RESEARCH APPROACH}

When selecting schools to take part in both the questionnaire study and the case studies the CI's and the case study researchers were asked to select schools that were representative of all of those in the Mpumalanga province. There was no differentiation between schools with various levels of resources and between exmodel C schools and DET schools. All schools were treated uniformly, accepting that they were representative of the diversity of schools in Mpumalanga. In many cases the selection of the schools was made based on the convenience of access for the researcher or CI involved in the specific districts. More assurance could have been given to the study had a stratified random sampling method been applied to select schools for both the questionnaire and the cases studies.

The questionnaire data were self-reported. There is a risk that self reported data could reflect what the teachers believe the researcher expects to see or what reflects most positively on their own abilities and knowledge. The questionnaire was filled in anonymously and with the assurance of complete confidentiality, so no teacher stood to gain by not being truthful in their responses. In addition, the teachers were made to understand that the results of the survey would be used to improve the situation in their teaching where it could be, i.e., new learner

support material could be designed to address any issues emanating from the 
survey with regards to implementation issues. The questions posed in the survey questionnaire were mostly based on issues that there would be little gain for the teachers in exaggerating such as years of experience teaching various subjects, or how many learners in the teachers' classes were hungry when they came to school. To counteract possible exaggeration, data from case studies were included to support the questionnaire study. It was found that in some cases there had been some exaggeration.

However, the relationships between variables are likely to be the same whether the data are reported accurately or exaggerated. If a linear relationship exists between two variables, whether the data is exaggerated or not, makes no difference. Therefore, only the first research focus could be affected by exaggeration. The case study data were used to compare the data for the research focus.

\subsection{RECOMMENDATIONS}

From the data analysis it is clear that moderate to high socio-economic circumstances and a healthy School Community are two very important factors for bringing about a good profile of implementation of curriculum change. Some recommendations for improving the health of a school community are made below. Recommendations on improving the socio-economic status of learners are beyond the ambit of this thesis. However, some thoughts on how socio-economic circumstances affect implementation are given.

\subsubsection{Leadership}

Both Fullan (2002) and Malcolm et al (2000) have written that the role of the principal is crucial in curriculum change. Fullan (2002) defines a good principal as one who is a change leader, who is eager to change the culture within his/her school and who is comfortable in leading schools in a rapidly changing society. As a change leader, a principal will sustain reform, develop the broader social environment, continue to educate him or herself in the workplace with regards the changes required (and encourage others to do so), cultivate leaders at all levels of the organization, and enhance the teaching profession. 
Leadership in the context of this study refers to all those individuals who provide support to and who monitor teachers. The list will include HODs, principals, curriculum implementers, circuit managers and teams from the Department of Education. The importance of their roles therefore has to be recognized. They should all be provided with consistent training themselves and should network amongst themselves to ensure that they all have a common purpose in mind of supporting and monitoring classroom implementation of C2005.

Given the need for good leadership, the inadequate training and the perceptions by the leadership that their training is adequate (v.d. Westhuizen et al, 2004), it is suggested that leadership training be re-evaluated. What is required of an education leader during curriculum change should be explicitly stated as outcomes and training towards the achievement of those outcomes should be focused and deliberate.

\subsubsection{Teachers}

Interaction between teachers within the same cluster as well as within the school is important and should therefore be encouraged. Clustering of schools and regular meetings held between teachers from the different schools should be supported. This interaction assists in producing better quality learning materials as teachers share ideas and resources. In addition, the meetings are a good forum for the sharing of problems with implementation and the brain-storming of solutions. The same benefits, but on a smaller scale can be expected from meetings between teachers of the same subject within the same school.

It appears that a positive work ethic predicts a good profile of implementation. Being in class when expected and treating learners with dignity are predictors of a good profile of implementation. The motivation to have a good work ethic is both intrinsically as well as extrinsically driven. The leadership of the school could play an important role here by ensuring that teachers know what is expected of them and by being exemplary in the execution of their own work.

\subsubsection{Resources}

Howie (2002) states that adequate resources are believed to be essential for quality teaching and learning to take place in a school. In her study she found that over $50 \%$ of the principals in her study indicated that their capacity for 
effective schooling was affected "a lot" by the lack of or inadequacy of instructional materials such as textbooks. Findings in our study indicate that several resources are required to improve the profile of implementation. These include teaching materials, apparatus and office facilities. Textbooks are essential learning aids particularly for learners from poor homes. It is therefore imperative that the Department of Education sees to it that all schools are adequately resourced with both support materials for teachers and learners.

\subsubsection{A differentiated approach to implementation}

The one-size fits all approach to the implementation of C2005 has clearly been unsuccessful in Mpumalanga. It appears that the very complex C2005 was intended to be implemented as if all the school in South Africa were of Hopkins' (1997) Class III level. What has to be acknowledged is that the majority of schools in South Africa, particularly those in the rural areas, are at the level of Hopkins' Class I or maybe lower. It cannot be realistically expected that schools performing below Class I through to Class III all take on the same curriculum innovation at the same pace. The result is often that the Class I school will become paralysed and make little or no progress, or as in some cases we saw in the cases studies, regress. Rogan (2007) proposes the concept of a zone of feasible innovation (ZFI) whereby schools must be acknowledged as being on a scale of low to high capacity to Innovate, and small steps must be mapped out in order to improve teaching incrementally over a period of time. It is important for the Department of Education to acknowledge this reality of South African Schools and develop a series of interventions based on Rogan's ZFI.

\subsubsection{Socio-economic conditions}

In our study, socio-economic circumstances proved to be very important. More than half the South African public lives below the breadline. It is therefore a mammoth task for the government to improve the standard of living in order to improve education. However, some steps towards improving the education of the poor in order to alleviate poverty have to be made. If the school socioeconomic status can be improved, with a resulting improvement in culture and climate, improved practice will result that will impact positively on learner achievement. The Department of Education should therefore target schools in impoverished areas, increasing their socio-economic status and focus on their capacities to improve education. 
In addition, a small effort could be made in communities to try and alleviate the problem of learners having few learning materials at home because of their poor home circumstances. Materials such as books, and electronic resources should be made available in community libraries and children should be encouraged to attend these libraries in their leisure time.

\subsection{CONCLUSION}

By 2003, South Africa had been a new democracy for almost a decade and many efforts had been made to improve education for all with the introduction of C2005. However, the changes in the classroom were tentative and small. The training of teachers and their leadership had in most cases been inadequate for the magnitude of the change required of them in their professional practice. Little had been provided that was truly effective in terms of resources to ensure successful implementation of C2005. The one-size fits all approach for the implementation of C2005 had not been successful. It is important therefore that the Department of Education in South Africa revisit its implementation strategies and ensure that all teachers and their leaders are adequately trained to play their roles effectively.

Our study has shown that the socio-economic circumstances of the community play an important role in the implementation of a sophisticated curriculum such as C2005. Where parents are under-educated, where learners come from indigent homes and where their schools are under-resourced, it is unlikely that that progress will be quick and effective. Improvement in education therefore has to take place alongside the economic uplifting of the general South African population. As poverty eradication takes place, so the Department of Education must ensure that everyone in their employ is properly prepared and that schools are well resourced. 


\section{SUMMARY}

\section{The implementation of C2005 in mathematics and science classes in Mpumalanga}

\section{INTRODUCTION}

The new Government of National Unity that came into power in 1994 jettisoned apartheid education and introduced an entirely new curriculum. Education was no longer portioned into unique curricula for various race groups. There was now a single curriculum for all South Africans regardless of race, which had as a major thrust, the introduction of outcomes-based education (OBE). The first efforts at curriculum change after the 1994 elections were met with optimism because of the intended abolishing of a racially defined education, but they also attracted wide criticism. By the turn of the century, research tracking the effects of curriculum change indicated that the distance between privileged schools and disadvantaged schools had increased rather than decreased.

As a consequence of the problems with the implementation of C2005, a major review of the new curriculum was undertaken which resulted in the Revised National Curriculum Statement (RNCS). The RNCS became policy in 2002. On the whole, academics remained sceptical about the new curriculum throughout the review process that led to the RNCS. They argued that the problems were not with OBE per se, but rather with issues connected to it such as teacher education, learning support materials, provincial support and time frames (Chisholm, 2003). It appeared that a high-quality curriculum had been created but with no consideration of the tools required for implementation. There was, and remains, a plethora of questions that can be researched into the disappointing uptake of C2005. It is imperative therefore that much research must be undertaken to analyse and understand the situation as it is and how it got there in South Africa. Research of this nature might illuminate the path for further change. 
It is within this context that this study pursues an investigation into what factors at the implementation levels should be considered in South Africa in order to improve the implementation process of new curricula, given the diversity of schools and their capacities to implement new curricula. A theoretical framework has been selected that has within it three defined areas that might affect successful curriculum implementation. Each of these areas has a variety of specific impacting factors for consideration. To this end the framework proposed by Rogan and Grayson (2003) is used to define the scope of the study.

\section{CONCEPTUAL FRAMEWORK AND RESEARCH QUESTIONS}

By 2003, Rogan and Grayson (2003) had identified that the progress of curriculum change in South Africa was difficult and slower than had been planned. Having identified the need to address implementation issues, they suggested that a theory of implementation ought to be developed for South Africa that might be transferable to other developing countries. In drawing up the theory their main aim was to address issues of particular relevance to developing countries, while drawing on international literature on educational change.

Rogan and Grayson (2003) proposed that a theory of implementation could be based on three major constructs viz. Profile of Implementation, Capacity to Innovate and Outside Influences. These three constructs can all be measured by means of indicators and are broad enough to include related factors, or subconstructs. There are levels within the sub-constructs that show a move from traditional practices through to practices considered ideal within the new curriculum, a move from acceptable old practice (practice appropriate within the traditional goals and objectives-based curriculum) to an outcomes based approach. The movement through the levels indicates a gradual implementation of the changes required in the new curriculum, from traditional practice to the new practice required of the curriculum change.

The three constructs and their sub-constructs of the Rogan-Grayson framework provide a systematic deconstruction of factors that may affect curriculum implementation. The structure and orderliness provided by the framework made it a very appropriate vehicle to investigate the situation in Mpumalanga in order to develop an insight into the status of curriculum changes taking place there. 
The framework was developed within the South African context by South African researchers, making it ideal for use in this study as further contextual knowledge was not required to alter the framework to fit. No other variables beyond the sub-constructs provided in the framework were thought necessary to add to the framework in its original form.

Broadly stated, the study reported in this dissertation focusses on two areas. It firstly analyses the state of various relevant factors pertaining to C2005 uptake in Mpumalanga schools. These include the three constructs within the Rogan and Grayson implementation framework as well as their sub-constructs. Secondly it investigates what the possible impact on implementation could be of: some influences outside of the school, as well as some factors that make up the fabric of the school.

The aim of this dissertation is to identify and analyse factors that may play a significant role in implementation of new curriculum policy. At an international level, this study will add to the literature on curriculum change, but with a distinctly unique flavour owing to the context of the research. The results of the study will be particularly important for the South African Education Department and in particular the MDE as it will shed some light on a how implementation might be secured after curriculum introduction.

\section{RESEARCH DESIGN}

The data for this dissertation were collected in two ways. Firstly teacher questionnaires were designed for a large scale survey. The second data collection method comprised of case studies. The data gathered from the questionnaire were used as the main source of data. The data from the case studies are used to explain, support or substantiate the findings of the questionnaire study.

The teacher questionnaire was developed throughout the duration of the first phase of the Mpumalanga Secondary Science Initiative (MSSI) and was administered in various forms in 2001, 2002 and 2003. The study that this dissertation reports on makes use of the data collected from the 2003 questionnaire. The 2003 questionnaire had the dual advantage of being administered in the final year of the first phase of the MSSI when the sample was 
at its largest, and the questionnaire had been refined through several revisions to be in line with the Rogan-Grayson framework, improving its content validity. This part of the study was quantitative and endeavoured to gather a large amount of data about the sub-constructs in the Rogan-Grayson framework (2003).Analysis of the data involved simple statistics, such as means, which were derived using the SAS (Statistical Analysis System) package. More complex statistical analyses were derived using SPSS (Statistical Package for the Social Sciences).

In January 2002 the results of the 2001 survey were reported and discussed at a specially arranged conference attended by JICA officials, personnel from the Mpumalanga Department of Education (mostly curriculum implementers) and researchers. The lack of case study type data was highlighted, and consequently the decision was made to undertake a series of case studies. One-week duration, in-depth studies of implementation of C2005 in twelve Mpumalanga schools were conducted during May and June 2002.

Although the case studies were carried out a year before the questionnaire based study reported on in this thesis, the schools for both studies are representative of the province as a whole. Not all the case study schools were included in the questionnaire study, but no direct comparisons within schools of both studies have been carried out for this study. The aim was not to generalise the findings to all the schools, but to gain an in-depth understanding of the processes and problems associated with the implementation of C2005 in the maths and science learning areas. The research on the case study data has been published elsewhere (Rogan \& Aldous, 2005) and is used in this study to support, illustrate, problematize and discuss the findings of the survey where appropriate.

\section{KEY FINDINGS}

Key findings were found to fall into two groups viz. school community and socio-economic circumstances.

School community:

- Several variables indicating the merits of including the parents, learners and staff in influencing the policy of the school were shown by our study to predict 
or correlate with successful C2005 implementation. This finding indicates that in Mpumalanga, like in other countries in the world, commitment to a common purpose by everyone involved with a school is an important pre- and co-requisite to curriculum implementation.

- The leadership within the school is shown to be important in curriculum implementation in Mpumalanga. The importance of support as well as monitoring and guidance given to teachers by their compliment of leaders from HOD's to principals to circuit managers and curriculum implementers is illustrated. However, in Mpumalanga it appears that more than support is required from the education leadership. The leadership must play an active role in pushing for change as well as supporting the teachers to enable them to carry out the directives for change.

- Collaborative planning and peer feedback amongst teachers were shown in our study to be beneficial for curriculum change in Mpumalanga

- It emerges from the data that proper functioning of the school is a significant factor in the success of curriculum implementation. Work ethic related variables included those for teachers and learners and it was found that in both cases work discipline is important.

- The education of the parents comes out as an important factor. The fact that parents' or guardians' education correlated with elements from the profile of implementation tells that in South Africa we have a long way to go in improving education for all before high level teaching practices can be achieved.

- An anomaly from the data is that it can be observed that learner proficiency in the language of instruction did not come out as a strong predictor.

\section{Socio-economic circumstances:}

It was not a focus of the questionnaire to interrogate the learner socio-economic status as almost all the schools were in areas populated by mainly impoverished communities. However, some variables that were predictors showed that the even small variations in the socio-economic status within a community do have an impact on curriculum change.

- The type of home that the learner comes from has an impact on curriculum implementation. A place to study after school in the home and the security of the neighbourhood are important factors in curriculum implementation.

- Another factor which affects implementation is the supply of textbooks to teach learners. 


\section{CONCLUSIONS}

By 2003, South Africa had been a new democracy for almost a decade and many efforts had been made to improve education for all with the introduction of C2005. However, the changes in the classroom were tentative and small. The training of teachers and their leadership had in most cases been inadequate for the magnitude of the change required of them in their professional practice. Little had been provided that was truly effective in terms of resources to ensure successful implementation of C2005. The one-size fits all approach for the implementation of C2005 had not been successful. It is important therefore that the Department of Education in South Africa revisit its implementation strategies and ensure that all teachers and their leaders are adequately trained to play their roles effectively.

This study has shown that the socio-economic circumstances of the community play an important role in the implementation of a sophisticated curriculum such as C2005. Where parents are under-educated, where learners come from indigent homes and where their schools are under-resourced, it is unlikely that progress will be quick and effective. Improvement in education therefore has to take place alongside the economic uplifting of the general South African population. As poverty eradication takes place, so the Department of Education must ensure that everyone in their employ is properly prepared and that schools are well resourced. 


\section{REFERENCES}

Aldous, C. (2004). Science and mathematics teachers' perceptions of C2005 in Mpumalanga secondary schools. African Journal of Research in Science, Mathematics and Technology Education, 8(1), 65-76.

Arnot, M., McIntyre, D., Pedder, D., \& Reay, D. (2003). Consultation in the classroom: Pupils perspectives on teaching and learning. Cambridge: Pearson.

Babbie E. (2000). The practice of social research (9th ed.). Belmont, CA: Wadsworth, 2000.

Beeby, C. E. (1966). The quality of education in developing countries. Cambridge, MA: Harvard University Press.

Bell, J. (1999). Doing your research project: A guide for first-time researchers in education and social science ( $3^{\text {rd }}$ ed). Buckingham: Open University Press.

Burtless, G. T. (1996). Does money matter? The effect of school resources on student achievement and adult success. Washington, DC: Brookings Institution Press.

Bybee, R. W. (1998). The Sputnik era: Why is this educational reform different from all other reforms? Paper given at the symposium Reflecting on Sputnik: Linking the past, present and future of educational reform hosted by the Centre of Science, Mathematics and Engineering Education of the National Academy of Sciences.

Bybee, R. W. \& De Boer, G. E. (1994). Research on goals for the science curriculum. In D. L. Gabel (Ed.), Handbook of research on science teaching and learning (pp. 357-385). New York: MacMillan Publishing Company.

Chisholm, L., \& Leyendecker, R. (2008). Curriculum reform in post-1990s sub-Saharan Africa. International Journal of Educational Development, 28, 195-205.

Chisholm, L. (2003). The politics of curriculum review and revision in South Africa. Paper presented at the Oxford International Conference on Education and Development, 9-11 September, 2003.

Clune, W. (1998). Toward a theory of systemic reform: The case of none statwide systemic initiatives. Research monograph no. 16. University of Wisconsin-Madison, National Institute for Science Education.

Comer, J. P. (1984). Home-school relationships as they affect the academic success of children. Education and Urban Society, 16(3), 323-37.

De Boer, G. E. (1998). What have we learned and where are we headed: Lessons from the Sputnik era. Paper given at the symposium Reflecting on Sputnik: Linking the past, present and future of educational reform hosted by the Centre of Science, Mathematics and Engineering Education of the National Academy of Sciences. 
Department of Education. (1997). Curriculum 2005: Lifelong learning for the 21st century. Pretoria: Department of Education.

Epstein, J. L. (1986). Parents' reactions to teacher practices of parent involvement. The Elementary School Journal, 6(3), 277.

Epstein, J. L., \& Dauber, S. L. (1991). School programs and teacher practices of parent involvement in inner-city elementary and middle schools. Elementary School Journal, 91, 291-305.

Fernandez, C. (2002). Learning from Japanese approaches to professional development: The case of lesson study. Journal of Teacher Education, 53(5), 393-405.

Figlio, D. N. (1999). Functional form and the estimated effects of school resources. Economics of Education Review, 18(2), 241-252.

Fullan, M. (1983). Evaluating program implementation: What can be learned from follow through. Curriculum Inquiry, 13(2), 215-227.

Fullan, M. (1998). The meaning of educational change: A quarter of a century of learning. In A. Hargreaves, A. Lieberman, M. Fullan, \& D. Hopkins (Eds.), International handbook of educational change, Part one (pp. 214-228). Dordrecht: Kluwer Academic Publishers.

Fullan, M. (2000). The return of large scale reform. Journal of Educational Change, 1, 5-28.

Fullan, M. (2002). Principals as leaders in a culture of change. Educational Leadership, 59(8), 16 21.

Fullan, M. (2007). The new meaning of educational change (4th ed). New York: Teachers College Press.

Fullan, M. (2008). Curriculum implementation and sustainability. In F. M. Connelly, M. F. He, \& J. Phillion (Eds.), The SAGE handbook of curriculum and instruction. California.

Fullan, M., \& Pomfret, A. (1977). Research on curriculum and instruction implementation. Review of Education Research, 47(1), 335-397.

Fuller, B., \& Clarke, P. (1994). Raising school effects while ignoring culture? Local conditions and the influence of classroom tools, rules, and pedagogy. Review of Educational Research, 64(1), 119-157.

Goodlad, J. I. (1979). Curriculum inquiry: The study of curriculum practice. New York: McGrawHill.

Government Gazette. (15 March 1995). White paper on education and training, 357 (16312). Cape Town.

Gray, B. V. (1999). Science education in the developing world: Issues and considerations. Guest editorial. Journal of Research in Science Teaching, 36(3), 261-268.

Hammersley, M. (1987). Some notes on the terms 'validity' and 'reliability. British Educational Research Journal, 13(1), 73-81.

Hanushek, E. A. (1997). Assessing the effects of school resources on student performance: An update. Educational Evaluation and Policy Analysis, 19(2), 141-164.

Harber, C. (2001). State of transition: Post-apartheid educational reform in South Africa. Oxford: Symposium Books. 
Hargreaves, A., \& Hopkins, D. (1991). The empowered school. London: Cassell.

Harley, K., \& Wedekind, V. (2004). In L. Chisholm (Ed.), Changing class. Cape Town: HSRC press.

Hewson, P. W., Butler-Kahle, J., Scantlebury, K., \& Davies, D. (2001). Equitable science education in urban middle schools: Do reform efforts make a difference? Journal of Research in Science Teaching, 38(10), 1130-1144.

Hofmeyr, J., \& Buckland, P. (1992). Education system change in South Africa. In R. McGregor, \& A. McGregor (Eds.), McGregor's education alternatives (pp. 15-59). Kenwyn: Juta's \& Co.

Hopkins, D. (1990). The International School Improvement Project (ISIP) and effective schooling: Towards a synthesis. School Organization, 10(2\&3), 179-194.

Hopkins, D. (1993). A teacher's guide to classroom research (2nd ed). Buckingham: Open University Press.

Hopkins, D. (2000). Powerful learning, powerful teaching and powerful schools. Journal of Educational Change, 1, 135 - 154.

Hopkins, D., \& Harris, A. (1997). Understanding the school's capacity for development: Growth states and strategies. School Leadership and Management, 17(3), 401-412.

Hopkins, D., Beresford, J., \& West, M. (1998). Creating the conditions for classroom and teacher development. Teachers and Teaching, 4(1), 115-141.

Hopkins, D., \& MacGilchrist, B. (1998). Development planning for pupil achievement. School Leadership and Management, 18(3), 409-424.

Howie, S. (2002). English language proficiency and contextual factors influenceing mathematics achievement of secondary school pupils in South Africa. Doctoral dissertation. Enschede: University of Twente.

Jansen, J. (1999a). Globalization, curriculum and the third world state: In dialogue with Micheal Apple, Current issues in comparative education, 1(2) [online] 1(2) available at: http://www.tc.colombia.edu/cice/articles/jj112.htm

Jansen, J. D. (1999b). Why OBE will fail: An elaboration. In J. Jansen, \& P. Christie (Eds.), Changing curriculum: Studies on outcomes based education in South Africa (pp. 145-156). Kenwyn: Juta.

Jansen, J. D. (1999c). The school curriculum since apartheid: Intersections of politics and policy in the South African transition. Journal of Curriculum Studies, 31(1), 57-67.

Jansen, J. D. (1998). Curriculum reform in South Africa: A critical analysis of outcomes-based education. Cambridge Journal of Education, 28(3), 321-331.

Joyce, R. B., \& Showers, B. (1995). Student achievement through staff development (2nd ed.). New York: Longman.

Kapp, M. S. (1997). Between systemic reforms and the mathematics and science classroom: The dynamics of innovation, implementation and professional learning. University of WisconsinMadison: National Institute for science education, Research monograph 1. 
Keller, G., \& Warrack, B. (2000). Statististics for management and economics (5 $5^{\text {th }}$ ed.). Duxbury, Pacific Grove.

Leithwood, K. A. (1992). The move toward transformational leadership. Educational Leadership, 49(5), 8-13.

Lewin, K., \& Dunne, M. (2000). Policy and practice in assessment in Anglophone Africa: Does globalisation explain convergence? Assessment in Education, 7(3), 379-399.

Leyendecker, R., Ottevanger, W., \& van den Akker, J. (2008). Curricula, examinations, and assessment in secondary education in Sub-Saharan Africa. Washington, DC: The World Bank.

Malcolm, C., Keane, M., Hoolo, L., Kgala, M., \& Owens, J. (2000). Why some 'disadvantaged' schools succeed in mathematics and science: A study of 'feeder' schools. South Africa: University of the Witwatersrand, RADMASTE Centre.

Marah, J. K. (2006). The virtues and challenges of traditional African education. The Journal of Pan African Studies, 1(0), 15-24.

Mbingo, S. J. (2006). An investigation into the implementation of the new curriculum by foundation phase teachers in Bethal Mpumalanga. Mini-dissertation submitted in partial fulfilment of the degree Magister Educationis. Johannesburg: University of Johannesburg.

McGrath, S. (1998). National policies and institutional practices: The credibility gap in South African education and training reform. Journal of Vocational Education and Training, 50(4), $503-518$.

MacKenzie, C. G. (1993). New models of school management in South Africa: License for cahnge or loophole for seperatism? British Journal of Educational Studies, 41(3), 287-301.

Miles M., \& Huberman, A. M. (2002). The qualitative researcher's companion. Beverley Hills, CA: Sage Publications.

Montero-Sieburth, M. (1992). Models and practice of curriculum change in developing countries. Comparative Education Review, 96(2), 175-193.

Nagao, M. (2004). Could Japan be good math \& science teacher for Africa? Journal of International Cooperation in Education, 7(1), 53 -70.

National Centre for curriculum Research and Development. (2000). Synthesis of documents on C2005. Pretoria: Department of Education.

Nzimande, B. (1997). Forward. In P. Kallaway, G. Kruss, A. Fataar, \& G. Donn, Education after Apartheid: South Africa Education in Transition (pp. 1-8). Cape Town: University of Cape Town Press.

Obanya, P. (1994). Curriculum reform for educational development in Africa: The role of UNESCO. Breda series, no 8. UNESCO.

Ofir, Z. (2002). An evaluation of the first phase of the Mpumalanga Secondary Science Initiative (MSSI). Report submitted to the Japan International Cooperation Agency. Pretoria: UP.

Ogunniyi, M. B. (1986). Two decades of science education in Africa. Science Education, 70(2), 111-122. 
Ono, Y., Chikamori, K., Ozawa, H., \& Kita, M. (2007). Evaluating project impact: The case of MSSI in South Africa. In J. Rogan, M. Nagao, \& M. Magno, Mathematics and science education in developing countries: Issues, experiences and cooperation proscts (pp. 322-336). Phillipines, Quezon City: The University of Philippines Press.

Osaki, K. M. (2004). Reflections on the state of science education in Tanzania. In K. Osaki, K. Hosea, \& W. Ottevanger (Eds.), Reforming science and mathematics education in sub-Saharan Africa: Obstacles and opportunities (pp. 1-10) Tanzania, University of Dar es Salaam: TEAMS Project.

Osaki, K. M. (2002). Science education in Tanzania: Past, present and future trends. Paper presented at the SAARMSTE conference 2002.

Ottevanger, W., van den Akker, J., \& de Feiter, L. (2007). Developing science,mathematics and ICT education in Sub-Saharan Africa. Patterns and promising practices. Washington, DC: The World Bank.

Prophet, R. B. (1990) Rhetoric and reality in science curriculum development in Botswana. International Journal of Science Education, 12(1), 13-23.

Rogan, J. M. (2000) Strawberries, cream and the implementation of curriculum 2005: Towards a research agenda. South African Journal of Education, 20, 118-125.

Rogan, J. (2007a). An uncertain harvest: A case study of implementation of innovation. Journal of Curriculum Studies, 39(1), 97-121.

Rogan, J. (2007b). How much curriculum change is appropriate? Defining a zone of feasible innovation. Science Education, 91(3), 439-460.

Rogan, J. M., \& Aldous, C. M. (2004). The monitoring and avaluation of the impact that MSSI has had on secondary schools in the Mpumalanga province. Japan, Hiroshima University: Centre for the Study of International Cooperation.

Rogan, J. M., \& Aldous, C. M. (2005). Relationships between the constructs of a theory of curriculum implementation. Journal of Reasearch in Science Teaching, 42(3), 313-336.

Rogan, J. M., \& Grayson, D. (2003). Towards a theory of curriculum implementation with particular reference to science education in developing countries. International Journal of Science Education, 25, 1171-1204.

Rogan, J. M., Grayson, D. J., van den Akker, J., Dlamini, S., Ndlalane, T., \& Aldous, C. M. (2002). The implementation of C2005 in Mpumalanga: Towards a theory of implementation. In C. Malcolm, \& C. Lubisi (Eds.), Proceedings of the Tenth annual conference of the Southern African Association for Research in Mathematics, Science and Technology Education, University of Natal, Durban (pp. III340-III350).

Rogan, J., Nagao, M., \& Magno, M. (2007). Mathematics and science education in developing countries: A historical overview. In J. Rogan, M. Nagao, \& M. Magno, Mathematics and science education in developing countries: Issues, experiences and cooperation propects (pp. 321). Phillipines, Quezon City: The University of Philippines Press.

Rudduck, J. (1996). Pupil's experiences of teaching and learning. Swindon: Economic and Social Research Council. 
Rudduck, J., Chaplian, R., \& Wallace, G. (1996). School improvement: What can pupils tell us? London: Dave Fulton.

Rudduck, J., \& Flutter, J. (2004a). The challenge of year 8. London: Pearson.

Rudduck, J., \& Flutter, J. (2004b). How to improve your school. London: Continuum.

Rudduck, J., \& Flutter, J. (2004c). Improving schools, involving pupils. London: Continuum.

Samoff, J. (1995). The reconstruction of schooling in Africa. In J. J. Lane (Ed.), Ferment in Education: A look abroad (pp. 9-57). Chicago: University of Chicago Press.

Sasrason, S. B. (1990). The predictable failure of educational reform. San Francisco: Jossey-Bass Publishers.

Scantlebury, K., Boone, W., Butler-Kahle, J., Fraser, B. J., (2001). Design, validation, and use of an evaluation instrument for monitoring systemic reform. Journal of Research in Science Teaching, 38(6), 646-662.

Stone, D. H. (1993). How to design a questionnaire. British Medical Journal, 307, 1264 -6.

Sifuna, D. N. (1992). Diversifying the secondary school curriculum: The African experience. International Review of Education, 38(1), 5-18.

Smith, M., \& O'Day, J. (1990). Systemic school reform. In S. H. Fuhrman, \& B. Malen (Eds.), The politics of curriculum and testing (pp. 233-268). Bristol, PA: Falmer Press.

South African Democratic Teachers Union (SADTU). (1995). Reports in document C: Report by regional education and development committee. Western Cape Province.

Supovitz, J. A., \& Turner, H. M. (2002). The effects of professional development on science teaching practices and classroom culture. Journal of Research in Science Teaching, 37(9), 963-980.

Thomson, P., \& Gunter, H. (2006). From 'consulting pupils' to 'pupils as researchers': A situated case narrative. British Educational Research Journal, 32(6), 839-856.

Trochim, W. M. K., \& Donelly, J. P. (2006). The research methods knowledge base. Kentucky: Atomic Dog Publishing.

Van den Akker, J. (1994). Designing innovations from an implementation perspective. In T. Husén, \& T. N. Postlethwaite, The international encyclopedia of education (2nd ed., Vol. 3, pp. 1491-1494). Oxford: Oxford Pergamon.

Van den Akker, J. (1998). The science curriculum: Between ideals and outcomes. In B. J. Fraser, \& K. G. Tobin (Eds.), International handbook of science education (pp. 421-477). Dordrecht: Kluwer Academic Publishers.

Van den Akker, J. (2003). Curriculum perspectives: An introduction. In J. van den Akker, W. Kuiper, \& U. Hameyer (Eds.), Curriculum landscapes and trends (pp. 1-10). Dordrecht: Kluwer Academic Publishers.

Van den Akker, J. (2005). Curriculum development re-invented: Evolving challenges for SLO. In J. Letschert (Ed.), Curriculum development re-invented (pp. 16-31). Proceedings of the invitational conference on the occasion of 30 years SLO 1975-2005. Enschede: SLO. 
Van der Westhuizen, P. C., Mosoge, M. J., \& van Vuuren, H. J. (2004). Capacity-building for educational managers in South Africa: A case study of the Mpumalanga Province. International Journal of Educational Development, 24(6), 705-719.

Verma, G. D., \& Mallick, K. (1999). Researching education - Perspectives and techniques. London: Falmer.

Verspoor, A. (1989). Pathways to change. Improving the quality of education in developing countries. Washington, DC: The World Bank.

Verspoor, A., \& Wu, K. B. (1990). Textbooks and educational development. Educational and Employment Division, Population and Human Resources, PHREE Background Paper Series No. PHREE/90/31. Washington, DC: The World Bank.

Walberg, H. J. (1991). Improving school science in advanced and developing countries. Review of Educational Research, 61(1), 25-69.

Wallace, J., \& Louden, W. (1998). Curriculum change in science: Riding the waves of reform. In B. J. Fraser, \& K. G. Tobin (Eds.), International handbook of science education (pp. 471485). Dordrecht: Kluwer Academic Publishers.

Welch, W. V. (1979). Twenty years of science curriculum development: A look back. In D. C. Berliner (Ed.), Review of research in education pp. 282-306. American Educational Research Association.

Weiss, C. H., \& Cambone, J. (1994). Principal's shared decision making, and school reform. Educational Evaluation and Policy Analysis, 16(3), 287 - 301.

Wenger, E. (1998). Communities of practice. Learning as a social system. Systems thinker, June 1998. Retrieved October 4, 2008, from http://www.co-i-l.com/coil/knowledgegarden/cop/lss.shtml

White, R., \& Gunstone, R. (1992). Probing understanding. London: Falmer Press.

World Bank. (2008). Curricula, examinations and assessment in secondary education in sub-Saharan Africa. Secondary Education in Africa (SEIA). Washington, DC: Africa Region Human Development Department.

Yoloye, E. A., \& Bajah, S. T. (1981). Science education for Africa, vol. 1: A report of twenty years of science education in Africa. SEPA.

Zucker, A. A., Shields, P. M., Adelman, N. E., Corcoran, T. B., \& Goertz, M. E. (1998). A report on the evaluation of the national science foundation's statewide systemic initiatives (SSI) Program. Menlo Park, CA: SRI International.

Zwane, S. K. F. (2004). Problems encountered by educators with the implementation of curriculum 2005 in Grade 8 classrooms in township school in the Bethal area. Mini-dissertation submitted in partial fulfilment of the degree Magister Educationis. Johannesburg: University of Johannesburg. 


\section{APPENDIX 1}

\begin{tabular}{|c|c|c|c|}
\hline Venue & Date & Aim & $\begin{array}{l}\text { Discussion and outcome in terms of } \\
\text { curriculum }\end{array}$ \\
\hline $\begin{array}{l}\text { Addis } \\
\text { Ababa }\end{array}$ & 1961 & $\begin{array}{l}\text { To establish a first tentative short- } \\
\text { term and long-term plan for } \\
\text { educational development in Africa }\end{array}$ & $\begin{array}{l}\text { Thought given to the basic curricular } \\
\text { prerequisites to educational reform }\end{array}$ \\
\hline Abidjan & 1964 & $\begin{array}{l}\text { To exchange experiences on efforts } \\
\text { made since independence to } \\
\text { rethink the objectives, the } \\
\text { structures and the content }\end{array}$ & $\begin{array}{l}\text { Agreed to expand the scope of the } \\
\text { school curriculum to include languages } \\
\text { and the natural sciences. Recommended } \\
\text { establishment of curriculum } \\
\text { development centres in member states. }\end{array}$ \\
\hline Nairobi & 1968 & $\begin{array}{l}\text { Review progress since Addis } \\
\text { Ababa conference, dwelling on } \\
\text { why planned targets were not } \\
\text { achieved }\end{array}$ & $\begin{array}{l}\text { Further advance in the 'curriculum } \\
\text { push'. General guidelines were given on } \\
\text { re-structuring primary and secondary } \\
\text { education, while specific attention was } \\
\text { paid to mathematics, science and } \\
\text { technology. Attention drawn to the need } \\
\text { for balanced curriculum content } \\
\text { bringing together scientific, cultural, } \\
\text { social and aesthetic disciplines }\end{array}$ \\
\hline Lagos & 1976 & $\begin{array}{l}\text { Started again with a review of } \\
\text { progress particularly with regard } \\
\text { curriculum issues. }\end{array}$ & $\begin{array}{l}\text { Concluded that African education was } \\
\text { still within the colonial paradigm with } \\
\text { its shortcomings. Recommended that } \\
\text { de-colonialisation of curricula be } \\
\text { undertaken. Emphasis placed on the } \\
\text { promotion of inter-African co-operation } \\
\text { in matters of curriculum renewal and } \\
\text { the recommendation of the African } \\
\text { Curriculum Organisation (ACO). }\end{array}$ \\
\hline Harare & 1982 & $\begin{array}{l}\text { Discuss problems in education in } \\
\text { Africa with particular reference to } \\
\text { language of instruction and } \\
\text { science and technology education }\end{array}$ & $\begin{array}{l}\text { Re-affirmed commitments and re- } \\
\text { iterated the recommendations of the } \\
\text { four preceding conferences. Problems } \\
\text { identified at the Addis Ababa } \\
\text { conference still remained unsolved and } \\
\text { therefore required more intensive action }\end{array}$ \\
\hline Dakar & 1991 & $\begin{array}{l}\text { Promotion of literacy and basic } \\
\text { education with emphasis on } \\
\text { promotion of African languages } \\
\text { and promotion of science and } \\
\text { technology. }\end{array}$ & $\begin{array}{l}\text { Recommended improvement in teacher } \\
\text { training and more interaction between } \\
\text { learners and their environment and } \\
\text { more participation in development } \\
\text { through the acquisition of knowledge } \\
\text { and the development of appropriate } \\
\text { skills and attitudes }\end{array}$ \\
\hline
\end{tabular}


APPENDIX 2 


\section{QUESTIONNAIRE TO TEACHERS - MAY 2003}
A Respondent number
B Type
C MSSI years
D Previous District
E School

Please answer each question by drawing a CIRCLE around the appropriate number in a shaded box or write your answer in the shaded space provided

\section{Part 1 About yourself}

1. Into which age group do you fall?

\begin{tabular}{|l|l|l|}
\hline a & Under 25 & $\mathbf{1}$ \\
\hline b & $25-29$ & $\mathbf{2}$ \\
\hline c & $30-39$ & $\mathbf{3}$ \\
\hline d & $40-49$ & $\mathbf{4}$ \\
\hline e & $50-59$ & $\mathbf{5}$ \\
\hline f & 60 or more & $\mathbf{6}$ \\
\hline
\end{tabular}

2. Are you female or male?

\begin{tabular}{|l|l|l|}
\hline $\mathrm{a}$ & Female & $\mathbf{1}$ \\
\hline $\mathrm{b}$ & Male & $\mathbf{2}$ \\
\hline
\end{tabular}

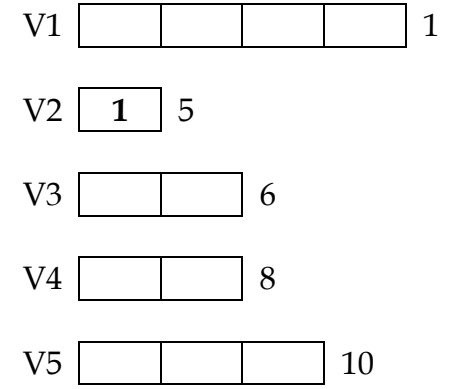

V6 $\square 13$

V7 $\square 14$ 


\begin{tabular}{|l|l|l|}
\cline { 2 - 3 } \multicolumn{1}{c|}{ Teaching } & \multicolumn{1}{c|}{ Years } \\
\hline a & Altogether? & \\
\hline b & At your current school? & \\
\hline c & Mathematics? & \\
\hline d & Physical Science? & \\
\hline e & Geology (Earth science)? & \\
\hline f & Geography? & \\
\hline g & Agriculture? & \\
\hline h & Biology? & \\
\hline i & Natural science? & \\
\hline
\end{tabular}

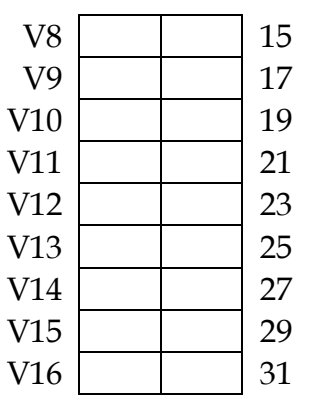

4. For which of the grades indicated below are you teaching mathematics this year? (Please indicate all grades that you are teaching mathematics)

\begin{tabular}{|c|c|c|c|c|}
\hline & Mathematics taught to & Yes & No & \\
\hline $\mathrm{a}$ & Grade 5 & 1 & 2 & V17 \\
\hline $\mathrm{b}$ & Grade 6 & 1 & 2 & V18 \\
\hline $\mathrm{c}$ & Grade 7 & 1 & 2 & V19 \\
\hline $\mathrm{d}$ & Grade 8 & 1 & 2 & V20 \\
\hline $\mathrm{e}$ & Grade 9 & 1 & 2 & V21 \\
\hline $\mathrm{f}$ & Grade 10 & 1 & 2 & V22 \\
\hline $\mathrm{g}$ & Grade 11 & 1 & 2 & V23 \\
\hline $\mathrm{h}$ & Grade 12 & 1 & 2 & V24 \\
\hline
\end{tabular}

5. For which of the grades indicated below are you teaching natural science this year? (Please indicate all grades that you are teaching general science)

\begin{tabular}{|c|c|c|c|c|c|}
\hline & Natural science taught to & Yes & No & \multirow{3}{*}{$\begin{array}{l}\text { V25 } \\
\text { V26 }\end{array}$} & \\
\hline $\mathrm{a}$ & Grade 7 & 1 & 2 & & 41 \\
\hline $\mathrm{b}$ & Grade 8 & 1 & 2 & & 42 \\
\hline C & Grade 9 & 1 & 2 & V27 & 43 \\
\hline
\end{tabular}


6. For which of the grades indicated below are you teaching physical science this year? (Please indicate all grades that you are teaching physical science)

\begin{tabular}{|c|c|c|c|c|}
\hline & Physical science taught to & Yes & No & \\
\hline $\mathrm{a}$ & Grade 10 & 1 & 2 & V28 \\
\hline $\mathrm{b}$ & Grade 11 & 1 & 2 & V29 \\
\hline C & Grade 12 & 1 & 2 & V30 \\
\hline
\end{tabular}

7. For which of the grades indicated below are you teaching biology this year? (Please indicate all grades that you are teaching biology science)

\begin{tabular}{|c|c|c|c|c|c|}
\hline & Biology taught to & Yes & No & & \\
\hline $\mathrm{a}$ & Grade 10 & 1 & 2 & V31 & 47 \\
\hline $\mathrm{b}$ & Grade 11 & 1 & 2 & V32 & 48 \\
\hline C & Grade 12 & 1 & 2 & V33 & 49 \\
\hline
\end{tabular}

8. How many of your grade 8 and 9 learners have access to textbooks during mathematics classes? Complete only if you teach mathematics

\begin{tabular}{|c|l|c|c|}
\cline { 2 - 4 } \multicolumn{1}{c|}{ Mathematics textbook access } & Grade 8 & Grade 9 \\
\hline a & Almost all & $\mathbf{1}$ & $\mathbf{1}$ \\
\hline b & About three quarters & 2 & 2 \\
\hline c & About half & 3 & 3 \\
\hline d & About a quarter & 4 & 4 \\
\hline e & None & 5 & 5 \\
\hline
\end{tabular}

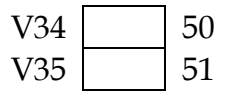

9. How many of your grade 8 and $\mathbf{9}$ learners have access to textbooks during natural science classes? Complete only if you teach natural science

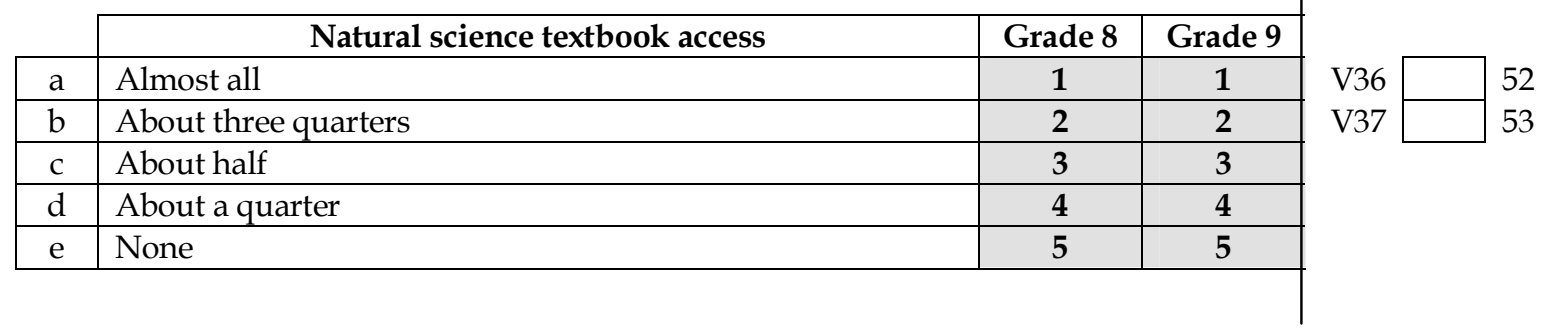




\section{Part 2 Implementation of Curriculum 2005}

\section{Classroom interaction}

10. A list of practices is given below, all of which have merit. The aim of this question is to determine which of these practices you use and how frequently you might use them. After each statement please circle one of the following numbers which have the meaning as indicated.
$\mathbf{1}=$ Never
(N) $\quad 2$ = Once a term
$3=$ Up to Three times a term
(T) $\quad 4=$ Once a Week
$(\mathbf{O})$
5 = Every Day
(D)

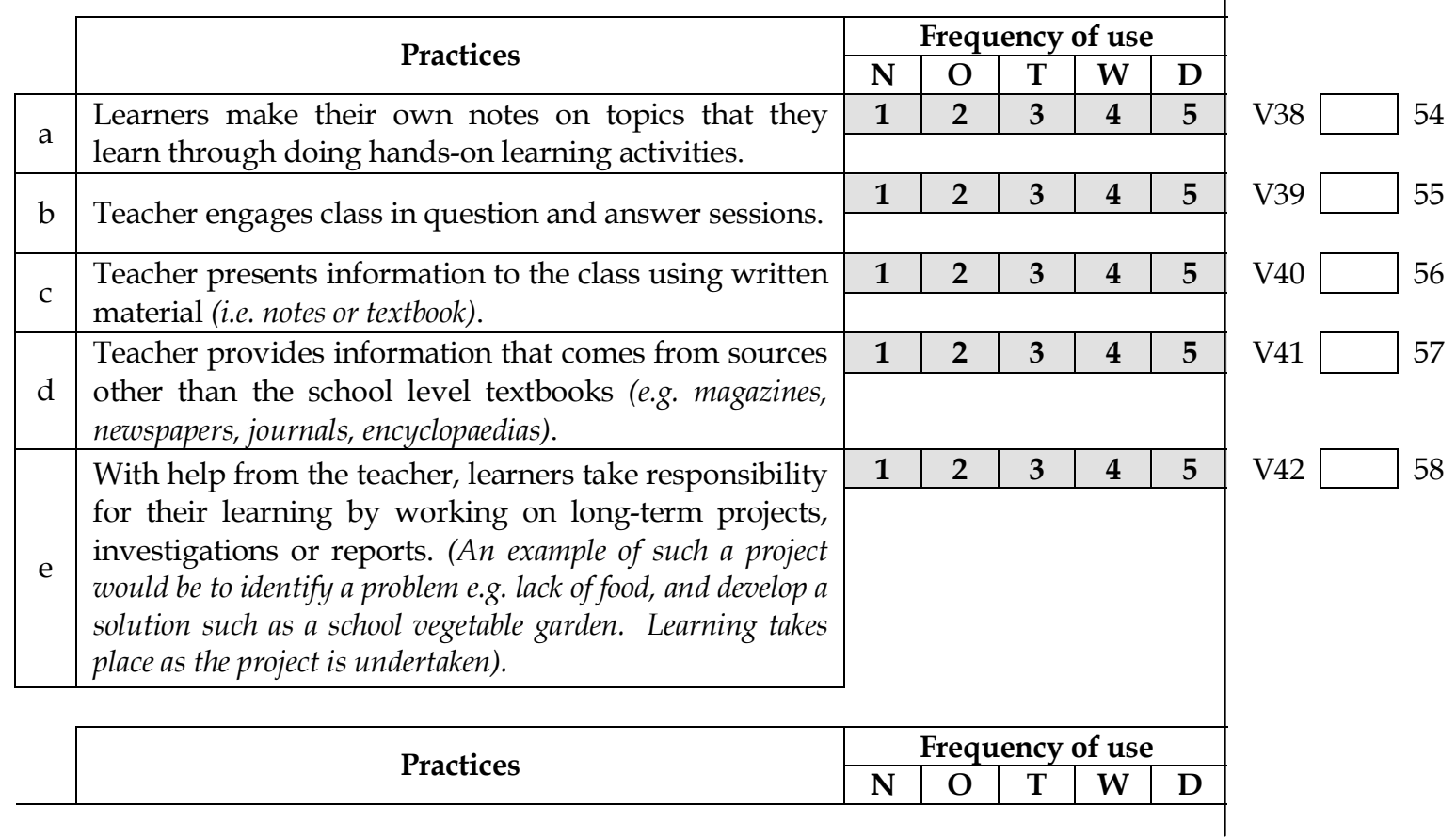




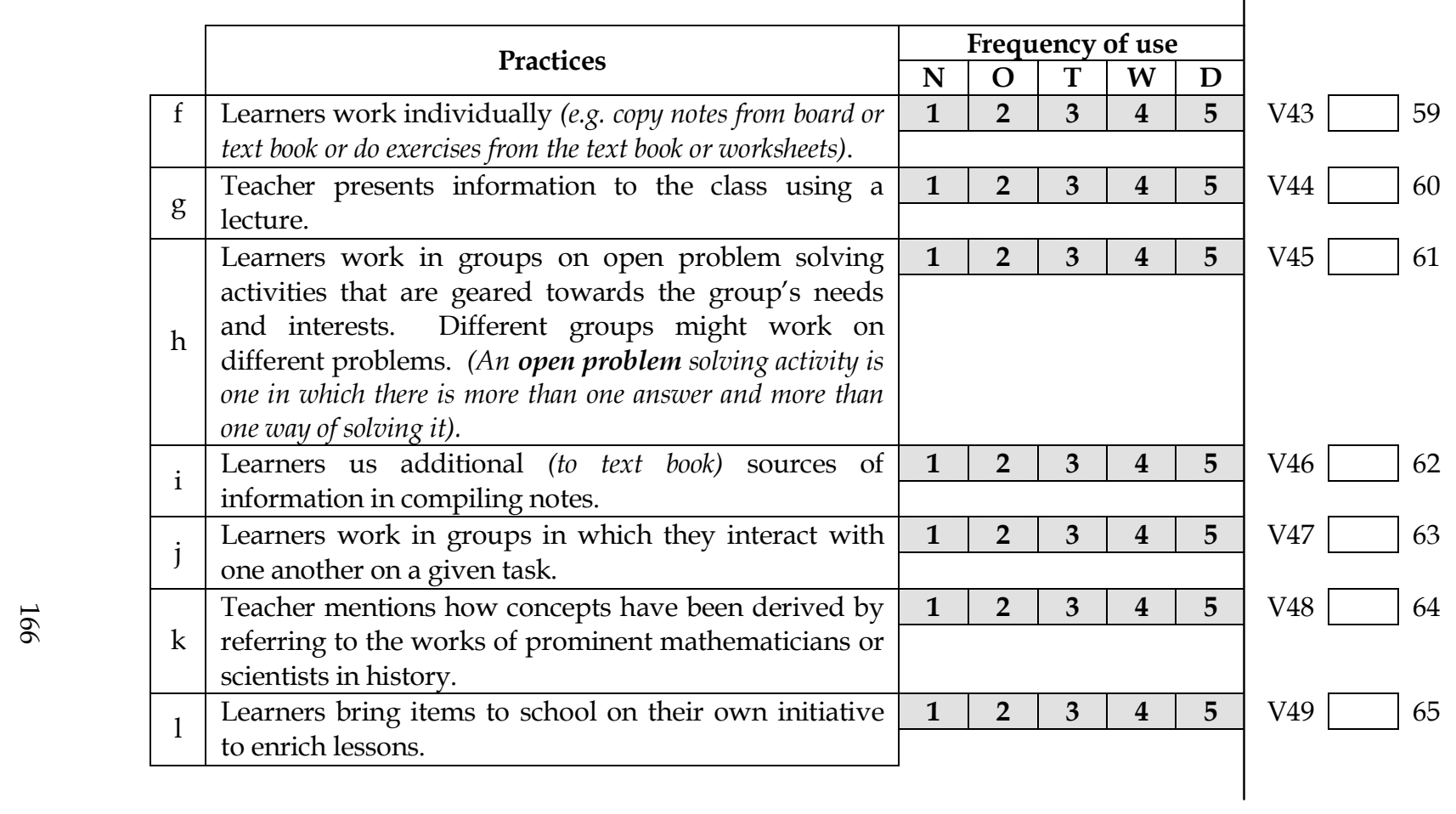




\section{Assessment practice}

11. A list of assessment practices is given below, all of which have merit. Which of these practices do you use and how frequently do you use them? After each assessment practice please circle one of the following numbers which have the meaning as indicated.
1. Never
2. Once a Year
3. Once a term
4. Up to three times a term

5 Once for Each sub-topic covered in class

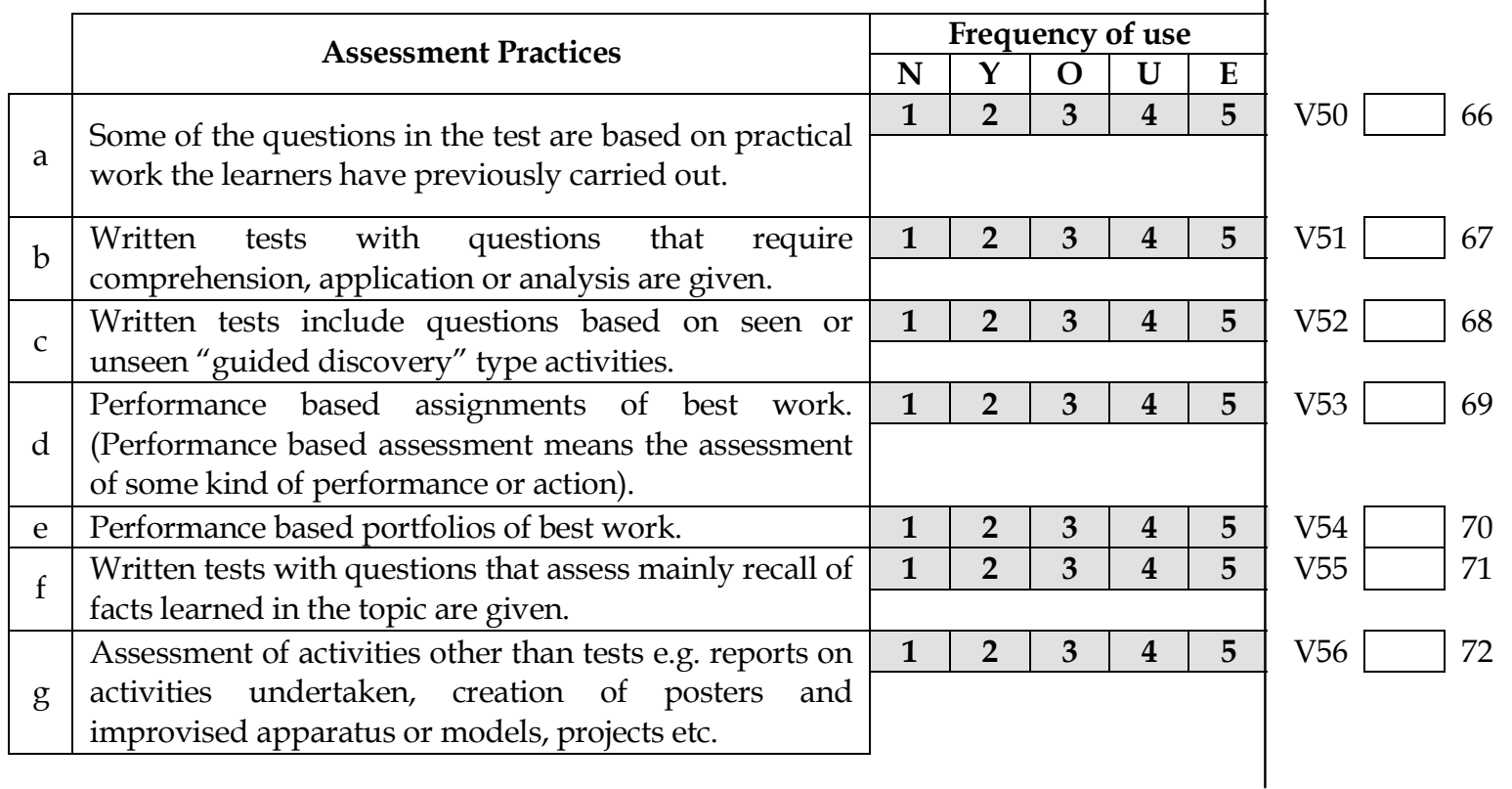




\section{Science and maths in Society}

12. A list of types of ways science/mathematics can be linked to societal issues is given below, all of which have merit. Please try to estimate the amount of time spent on societal issues devoted to the practices below. (It is not necessary that each of these practices is present) After each statement please circle one of the following numbers which have the meaning as indicated.
1 Never
2 Once a Term
O
3 Up to three Times a term $\mathbf{T}$
4 Once a Week
W
5 Every Day

D

\section{Practices}

Lessons are based on a specific problem or issue faced

a by the local community. (For example, access to water might be a problem around which lessons are based)

Teacher uses examples and applications from everyday life to illustrate scientific concepts or mathematics procedures

Learners actively undertake a project in their local community in which they apply science and c mathematics to tackle a specific problem or meet a specific need. (An example might be on growing a new type of crop (to that area) to increase the income of the community).

Learners actively investigate the application of science

$\mathrm{d}$ and mathematics in their own environment. (Examples are an audit of energy use and a traffic volume survey)

\begin{tabular}{|c|c|c|c|c|c|c|}
\hline \multicolumn{5}{|c|}{ Frequency of use } & \multirow[b]{3}{*}{ V57 } & \multirow[b]{3}{*}{73} \\
\hline $\mathbf{N}$ & $\mathrm{O}$ & $T$ & $\bar{W}$ & D & & \\
\hline 1 & 2 & 3 & 4 & 5 & & \\
\hline 1 & 2 & 3 & 4 & 5 & V58 & 74 \\
\hline
\end{tabular}

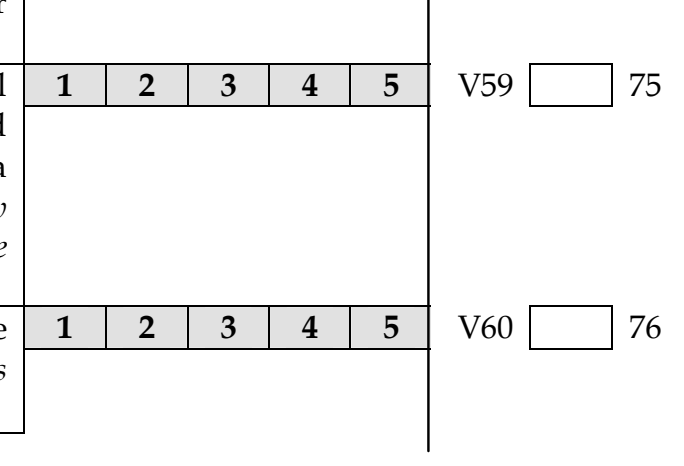




\section{Science Practical Work}

\section{(Note: Mathematics teachers need not complete question 13)}

13. A list of types of practical work is given below, all of which have merit. Of the time spent on practical work, please try to estimate how often you have used each of these practices in your classroom over the past month. (It is not necessary that each of these practices is present). After each statement please circle one of the following numbers which have the meaning as indicated.
1 Never
(N) 2 Once a Term
(O)
3 Up to three Times a term
5 Every Day
(T) 4 Once a Week $\quad$ (W)
(D)

\begin{tabular}{|c|c|c|c|c|c|c|c|}
\hline \multirow{2}{*}{ Practical Work } & \multicolumn{5}{|c|}{ Frequency } & \multirow{4}{*}{ V61 } & \\
\hline & $\mathbf{N}$ & $\mathrm{O}$ & $T$ & W & D & & \\
\hline \multirow{2}{*}{$\begin{array}{l}\text { Learners design their own "open" investigations. } \\
\text { They reflect on the quality of the design and collected } \\
\text { data and are able to modify to improve the quality of } \\
\text { the design }\end{array}$} & 1 & 2 & 3 & 4 & 5 & & \\
\hline & & & & & & & 77 \\
\hline \multirow{2}{*}{$\begin{array}{l}\text { Learners fill in worksheets that are given with a } \\
\text { practical task }\end{array}$} & 1 & 2 & 3 & 4 & 5 & \multirow[t]{2}{*}{ V62 } & \multirow[t]{2}{*}{78} \\
\hline & & & & & & & \\
\hline \multirow{2}{*}{$\begin{array}{l}\text { Learners perform practical work in groups using } \\
\text { apparatus. They are given a problem or question and } \\
\text { they then design their own experiment and ensure that } \\
\text { their data is accurate. }\end{array}$} & 1 & 2 & 3 & 4 & 5 & \multirow[t]{2}{*}{ V63 } & \multirow[t]{2}{*}{79} \\
\hline & & & & & & & \\
\hline \multirow{2}{*}{$\begin{array}{l}\text { Learners use data from demonstrations to construct } \\
\text { their own graphs and tables. }\end{array}$} & 1 & 2 & 3 & 4 & 5 & \multirow[t]{2}{*}{ V64 } & \multirow[t]{2}{*}{80} \\
\hline & & & & & & & \\
\hline \multirow{2}{*}{$\begin{array}{l}\text { Learners interpret data in support of competing } \\
\text { theories or explanations }\end{array}$} & 1 & 2 & 3 & 4 & 5 & \multirow[t]{2}{*}{ V65 } & \multirow[t]{2}{*}{81} \\
\hline & & & & & & & \\
\hline
\end{tabular}




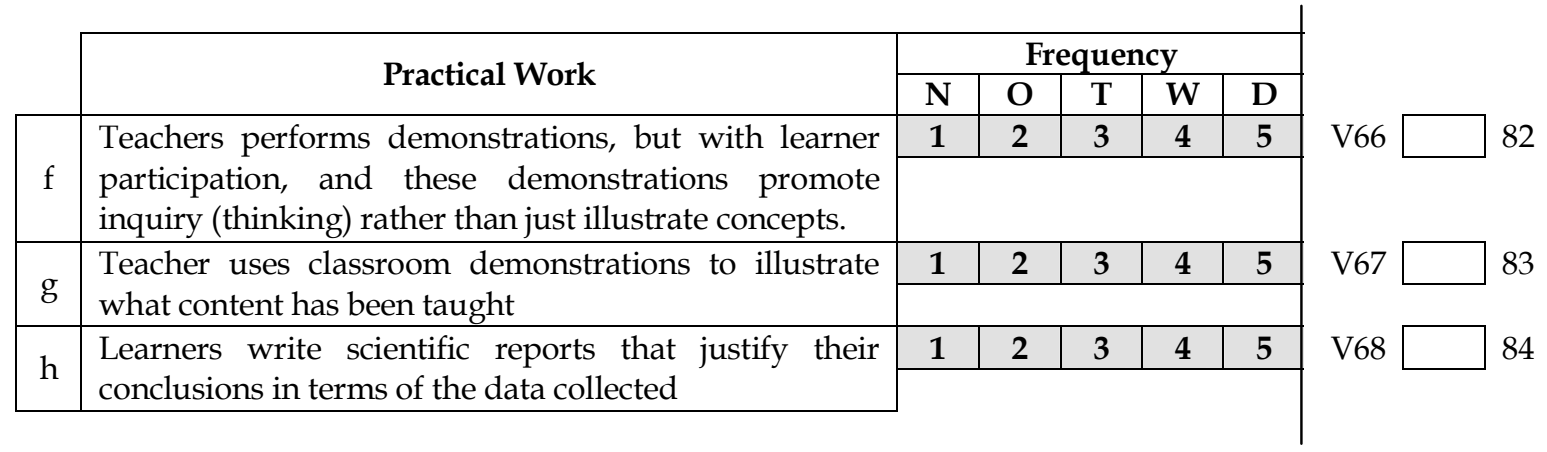




\section{Part 3 Factors that influence implementation}

Teacher factors

14. The following statements are about factors that could influence implementation of Curriculum 2005. After each statement please circle one of the following numbers which have the meaning as indicated.

Please indicate to what extent you agree or disagree with the following statements. After each statement please circle one of the following numbers which have the meaning as indicated.
$\mathbf{1}=$ Strongly Disagree
(SD)
$2=$ Disagree
(D)
$3=$ Agree
(A)
$4=$ Strongly Agree
(SA)

\begin{tabular}{|c|c|c|c|c|c|c|c|}
\hline \multirow{3}{*}{ a } & Statement & $\begin{array}{l}\mathbf{S} \\
\mathrm{D} \\
\end{array}$ & $\mathbf{D}$ & A & SA & \multirow{2}{*}{ V69 } & \multirow[b]{2}{*}{85} \\
\hline & \multirow{2}{*}{$\begin{array}{l}\text { If I were given the opportunity, I would leave teaching this } \\
\text { year. }\end{array}$} & 1 & 2 & 3 & 4 & & \\
\hline & & & & & & \multirow[b]{2}{*}{ V70 } & \multirow[b]{2}{*}{86} \\
\hline $\mathrm{b}$ & Morale in my school is low. & 1 & 2 & 3 & 4 & & \\
\hline $\mathrm{c}$ & In my school teachers are willing to try new teaching methods. & 1 & 2 & 3 & 4 & V71 & 87 \\
\hline \multirow{2}{*}{$\mathrm{d}$} & \multirow{2}{*}{$\begin{array}{l}\text { In my school we often discuss ideas and share materials with } \\
\text { colleagues who teach the same subject. }\end{array}$} & 1 & 2 & 3 & 4 & \multirow[t]{2}{*}{ V72 } & \multirow[t]{2}{*}{88} \\
\hline & & & & & & & \\
\hline \multirow{2}{*}{ e } & \multirow{2}{*}{$\begin{array}{l}\text { In my circuit teachers from different schools meet often so as } \\
\text { to support and encourage one another. }\end{array}$} & 1 & 2 & 3 & 4 & \multirow[t]{2}{*}{ V73 } & \multirow[t]{2}{*}{89} \\
\hline & & & & & & & \\
\hline \multirow{2}{*}{$\mathrm{f}$} & \multirow{2}{*}{$\begin{array}{l}\text { Effective school-based in-service training happens at my } \\
\text { school. }\end{array}$} & 1 & 2 & 3 & 4 & \multirow[t]{2}{*}{ V74 } & \multirow[t]{2}{*}{ ] 90} \\
\hline & & & & & & & \\
\hline $\mathrm{g}$ & In my circuit teachers meet with each other to plan lessons. & 1 & 2 & 3 & 4 & V75 & 91 \\
\hline \multirow[t]{2}{*}{$h$} & \multirow{2}{*}{$\begin{array}{l}\text { Teachers in my school make an extra effort to improve } \\
\text { teaching and learning. }\end{array}$} & 1 & 2 & 3 & 4 & \multirow[t]{2}{*}{ V76 } & \multirow[t]{2}{*}{92} \\
\hline & & & & & & & \\
\hline \multirow{2}{*}{$\mathrm{i}$} & Teachers at my school are often not in the classroom when & 1 & 2 & 3 & 4 & \multirow[t]{2}{*}{ V77 } & \multirow[t]{2}{*}{93} \\
\hline & they should be. & & & & & & \\
\hline \multirow{2}{*}{$\mathrm{j}$} & \multirow{2}{*}{$\begin{array}{l}\text { In my school, teachers reprimand learners for providing } \\
\text { incorrect answers e.g. by calling them stupid. }\end{array}$} & 1 & 2 & 3 & 4 & \multirow[t]{2}{*}{ V78 } & \multirow[t]{2}{*}{94} \\
\hline & & & & & & & \\
\hline
\end{tabular}




\section{School ecology and management}

15. These are school based factors that could influence implementation.

Please indicate to what extent you agree or disagree with the following statements. After each statement please circle one of the following numbers which have the meaning as indicated.
$\mathbf{1}=$ Strongly Disagree
(SD) $\quad 2=$ Disagree
(A) $\quad \mathbf{4}=$ Strongly Agree
(D)
$3=$ Agree
(SA)

\begin{tabular}{|c|c|c|c|c|c|c|c|}
\hline & Statement & $\begin{array}{l}\text { S } \\
\text { D }\end{array}$ & $\mathbf{D}$ & A & SA & \multirow{3}{*}{$\begin{array}{l}\text { V79 } \\
\text { V80 }\end{array}$} & \multirow[b]{2}{*}{95} \\
\hline $\mathrm{a}$ & I feel that my Principal supports me & 1 & 2 & 3 & 4 & & \\
\hline $\mathrm{b}$ & I feel that my Head of Department supports me & 1 & 2 & 3 & 4 & & 96 \\
\hline \multirow{2}{*}{ c } & \multirow{2}{*}{$\begin{array}{l}\text { Staff participate in the management of the school and } \\
\text { therefore have a say in the running of the school }\end{array}$} & 1 & 2 & 3 & 4 & \multirow[t]{2}{*}{ V81 } & \multirow[t]{2}{*}{97} \\
\hline & & & & & & & \\
\hline $\mathrm{d}$ & Learners have a say in the running of the school & 1 & 2 & 3 & 4 & \multirow{2}{*}{$\begin{array}{l}\text { V82 } \\
\text { V83 }\end{array}$} & \multirow{2}{*}{\begin{tabular}{|l|}
98 \\
99
\end{tabular}} \\
\hline $\mathrm{e}$ & Everyone in my school has a shared vision for the school & 1 & 2 & 3 & 4 & & \\
\hline $\mathrm{f}$ & Parents are actively involved with the school & 1 & 2 & 3 & 4 & \multirow[t]{2}{*}{ V84 } & \multirow[t]{2}{*}{0} \\
\hline $\mathrm{g}$ & Staff meetings are beneficial & & & & & & \\
\hline $\mathrm{h}$ & In my school we follow the timetable strictly & 1 & 2 & 3 & 4 & \multirow{2}{*}{$\begin{array}{l}\text { V85 } \\
\text { V86 }\end{array}$} & 10 \\
\hline $\mathrm{i}$ & The principal often walks around to see what is going on in & 1 & 2 & 3 & 4 & & 2 \\
\hline j & Extra mural activities interfere with classes & 1 & 2 & 3 & 4 & & 10 \\
\hline $\mathrm{k}$ & Learners are in class as scheduled & 1 & 2 & 3 & 4 & V88 & $\begin{array}{l}10 \\
4\end{array}$ \\
\hline 1 & Teachers are in class as scheduled & 1 & 2 & 3 & 4 & V89 & $\begin{array}{l}10 \\
5\end{array}$ \\
\hline
\end{tabular}




\section{Physical Resources}

16. Indicate in the table below whether your school has the resources listed, and, if so, what effect they have on the implementation of Curriculum 2005. After each resource please circle one of the numbers under either "Yes" or "No" as well as the numbers, under Effect on Implementation, which have the meaning as indicated.
$1=$ None
(N) $\quad 2$ = Small
(S)
$3=$ Moderate
(M) 4 = Large
(L)

\begin{tabular}{|c|c|c|c|c|c|c|c|c|}
\hline & \multirow[t]{2}{*}{ Resource } & \multicolumn{2}{|c|}{ Presence } & \multicolumn{4}{|c|}{$\begin{array}{c}\text { Effect on } \\
\text { implementation }\end{array}$} & \multirow[b]{3}{*}{ V90 } \\
\hline & & Yes & No & $\mathbf{N}$ & $\mathrm{S}$ & $\mathbf{M}$ & $\mathbf{L}$ & \\
\hline $\mathrm{a}$ & Teachers' guides & 1 & 0 & 1 & 2 & 3 & 4 & \\
\hline $\mathrm{b}$ & Worksheets & 1 & 0 & 1 & 2 & 3 & 4 & V92 \\
\hline C & Science apparatus & 1 & 0 & 1 & 2 & 3 & 4 & V94 \\
\hline $\mathrm{d}$ & Maths apparatus & 1 & 0 & 1 & 2 & 3 & 4 & V96 \\
\hline $\mathrm{e}$ & Laboratory & 1 & 0 & 1 & 2 & 3 & 4 & V98 \\
\hline $\mathrm{f}$ & Photocopying facilities & 1 & 0 & 1 & 2 & 3 & 4 & V100 \\
\hline $\mathrm{g}$ & Running water & 1 & 0 & 1 & 2 & 3 & 4 & V102 \\
\hline $\mathrm{h}$ & Electricity & 1 & 0 & 1 & 2 & 3 & 4 & V104 \\
\hline $\mathrm{i}$ & Computers & 1 & 0 & 1 & 2 & 3 & 4 & V106 \\
\hline $\mathrm{j}$ & Library & 1 & 0 & 1 & 2 & 3 & 4 & V108 \\
\hline \multirow{2}{*}{$\mathrm{k}$} & \multirow[t]{2}{*}{ Other (specify): } & 1 & 0 & 1 & 2 & 3 & 4 & \multirow{2}{*}{$\begin{array}{l}\text { V110 } \\
\text { V112 }\end{array}$} \\
\hline & & & & & & & & \\
\hline
\end{tabular}


17. Indicate to what extent each of the following resources are provided for learners at your school. After each resource please circle one of the following numbers which have the meaning as indicated.

$1=$ Almost All learners

$2=$ Most learners

(A) $\quad 90 \%-100 \%$

$3=$ Some learners

(M) $\quad 70 \%-89 \%$

$4=$ Few learners

(S) $\quad 30 \%-69 \%$

$\mathbf{5}=$ Almost No learners

(F) $\quad 10 \%-29 \%$

(N) $\quad 0 \%-9 \%$

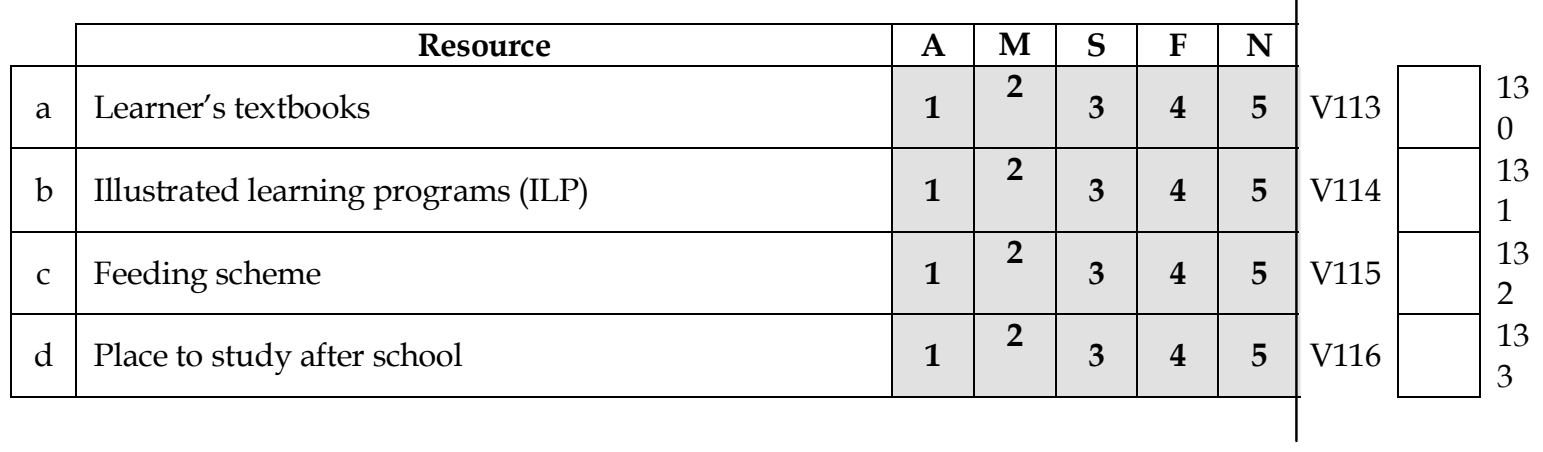




\section{Learner factors}

18. The following statements are about the background of your learners.

Estimate the percentage of your learners that are described by the following categories. After each category please circle one of the following numbers which have the meaning as indicated.

$\begin{array}{lll}\mathbf{1}=\text { Almost All learners } & \text { (A) } & \mathbf{9 0 \% - 1 0 0 \%} \\ \mathbf{2}=\text { Most learners } & \text { (M) } & \mathbf{7 0 \% - 8 9 \%} \\ \mathbf{3}=\text { Some learners } & \text { (S) } & \mathbf{3 0 \% - 6 9 \%} \\ \mathbf{4}=\text { Few learners } & \text { (F) } & \mathbf{1 0 \% - 2 9 \%} \\ \mathbf{5}=\text { Almost No learners } & \text { (N) } & \mathbf{0} \%-\mathbf{9 \%}\end{array}$

$5=$ Almost No learners

\begin{tabular}{|c|c|c|c|c|c|c|c|c|}
\hline & Category & $\mathbf{A}$ & $\mathbf{M}$ & $S$ & $\mathbf{F}$ & $\mathbf{N}$ & \multirow[b]{2}{*}{ V117 } & \\
\hline a & My learners come to school hungry. & 1 & 2 & 3 & 4 & 5 & & $\begin{array}{l}13 \\
4\end{array}$ \\
\hline $\mathrm{b}$ & My learners come from homes that have electricity. & 1 & 2 & 3 & 4 & 5 & V118 & 13 \\
\hline c & $\begin{array}{l}\text { My learners come from homes that have running } \\
\text { water. }\end{array}$ & 1 & 2 & 3 & 4 & 5 & V119 & $\begin{array}{l}13 \\
6\end{array}$ \\
\hline $\mathrm{d}$ & My learners live in a safe neighbourhood. & 1 & 2 & 3 & 4 & 5 & V120 & \\
\hline e & $\begin{array}{l}\text { The parents (or guardians) of my learners have a } \\
\text { matriculation (or higher) certificate. }\end{array}$ & 1 & 2 & 3 & 4 & 5 & V121 & \\
\hline $\mathrm{f}$ & $\begin{array}{l}\text { The parents (or guardians) of my learners' encourage } \\
\text { them to study. }\end{array}$ & 1 & 2 & 3 & 4 & 5 & V122 & \\
\hline $\mathrm{g}$ & My learners are able to attend school regularly. & 1 & 2 & 3 & 4 & 5 & V123 & \\
\hline $\mathrm{h}$ & My learners are motivated to study. & & & & & & & \\
\hline
\end{tabular}




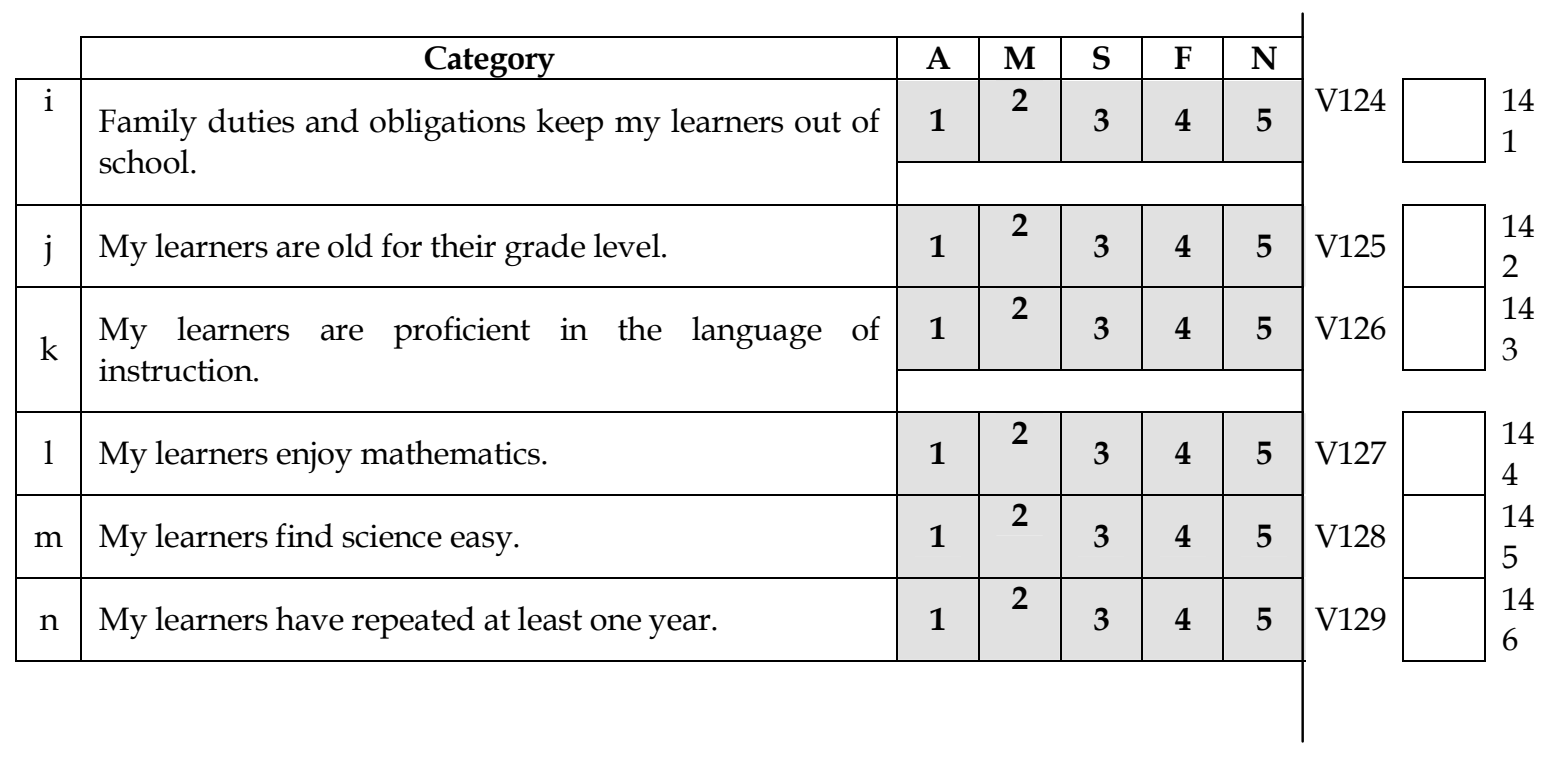




\section{Part 4 Outside influences}

19. For each of the following items, please circle one of the numbers which have the meaning as indicated, that best indicates how much that item influences your willingness to implement Curriculum 2005.
$1=$ None
(N) $\quad 2$ = Small
(S)
$3=$ Moderate
(M) $\quad 4=$ Large
(L)

\begin{tabular}{|c|c|c|c|c|c|c|c|}
\hline & \multirow[t]{2}{*}{ Item } & \multicolumn{4}{|c|}{$\begin{array}{l}\text { Willingness to } \\
\text { implement }\end{array}$} & \multirow{5}{*}{\begin{tabular}{|l|} 
V130 \\
V131 \\
V132
\end{tabular}} & \multirow{5}{*}{\begin{tabular}{|l}
147 \\
148 \\
149
\end{tabular}} \\
\hline & & $\mathbf{N}$ & $\mathrm{S}$ & $\mathbf{M}$ & $\mathbf{L}$ & & \\
\hline $\mathrm{a}$ & Curriculum 2005 policy documents & 1 & 2 & 3 & 4 & & \\
\hline $\mathrm{b}$ & Pressure from circuit managers & 1 & 2 & 3 & 4 & & \\
\hline \multirow{2}{*}{$\mathrm{C}$} & Materials on Curriculum 2005 from the Department of & 1 & 2 & 3 & 4 & & \\
\hline & Education & & & & & \multirow{8}{*}{$\begin{array}{l}\text { V133 } \\
\text { V134 } \\
\text { V135 } \\
\text { V136 } \\
\text { V137 } \\
\text { V138 }\end{array}$} & \\
\hline $\mathrm{d}$ & Support and encouragement from Curriculum Implementers & 1 & 2 & 3 & 4 & & 150 \\
\hline $\mathrm{e}$ & Concerns about disciplinary action being taken against me & 1 & 2 & 3 & 4 & & 151 \\
\hline $\mathrm{f}$ & The support of teachers in my school & 1 & 2 & 3 & 4 & & 152 \\
\hline $\mathrm{g}$ & The expectations of my learners & 1 & 2 & 3 & 4 & & 153 \\
\hline $\mathrm{h}$ & Loyalty to my principal and/or HOD & 1 & 2 & 3 & 4 & & 154 \\
\hline \multirow{2}{*}{$\mathrm{i}$} & \multirow{2}{*}{$\begin{array}{l}\text { The support and encouragement of other teachers in my } \\
\text { cluster }\end{array}$} & 1 & 2 & 3 & 4 & & \multirow[t]{2}{*}{155} \\
\hline & & & & & & & \\
\hline
\end{tabular}

\section{Professional development}

20. Have you attended any workshops on Curriculum 2005 since January 2001?

\begin{tabular}{|l|l|l|l|}
\hline $\mathrm{a}$ & Yes & $\mathbf{1}$ & $\mathrm{V} 139$ \\
$\mathrm{~b}$ & No & $\mathbf{2}$ & $\begin{array}{l}15 \\
6\end{array}$ \\
\hline
\end{tabular}


If "Yes" to Question 20, please complete item 21 below.

21. Indicate the effect of the workshops on your implementation of Curriculum 2005 in column four. After each statement please circle one of the following numbers which have the meaning as indicated.
$1=$ None
(N)
$2=$ Small
3 = Moderate
$4=$ Large
(L)

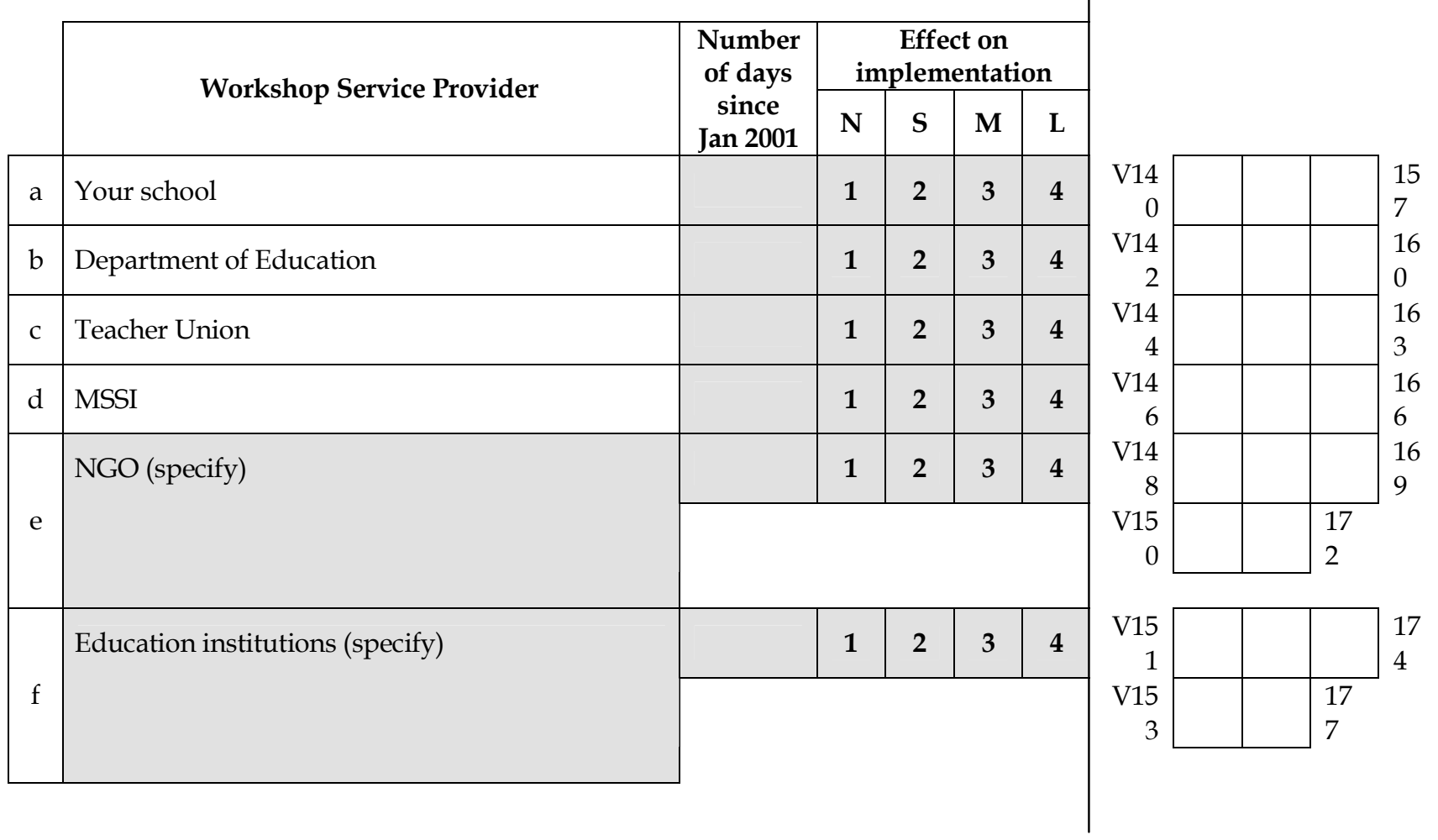




\section{Monitoring and accountability}

22. To what extent do the following persons monitor your school's compliance with the implementation of the Curriculum 2005 policy? After each statement please circle one of the following numbers which have the meaning as indicated.

$1=$ Not at all

$\mathbf{2}=$ To a Small extent

$(\mathbf{N})$

$3=$ To a Moderate extent

$4=$ To a Large extent

(M)

(L)

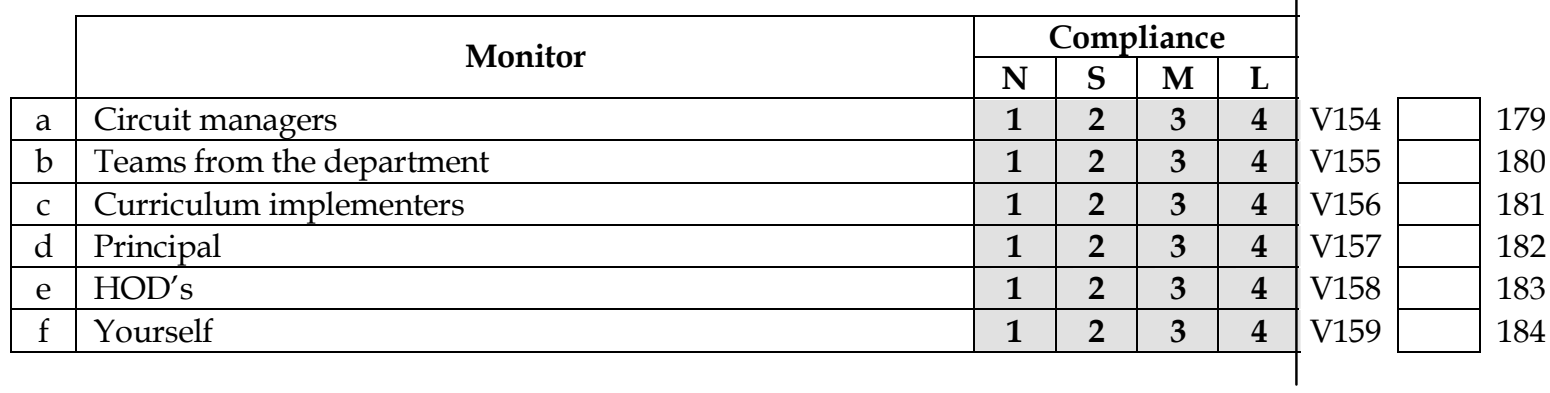

Thank you very much for your co-operation 
APPENDIX 3 
Items for each construct in the questionnaires from 2001 - 2003

\begin{tabular}{|c|c|c|c|c|}
\hline Construct & Sub-construct & $\begin{array}{l}\text { Teacher } \\
\text { questionnaire } 2001\end{array}$ & $\begin{array}{l}\text { Teacher } \\
\text { questionnaire } 2002\end{array}$ & $\begin{array}{l}\text { Teacher } \\
\text { questionnaire } 2003\end{array}$ \\
\hline \multirow{4}{*}{ 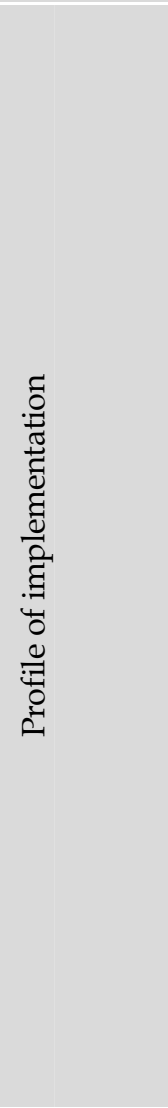 } & $\begin{array}{l}\text { Classroom } \\
\text { interaction }\end{array}$ & Q9 - V63 to V91 & $\begin{array}{l}\text { Q9 - V74 to V83 } \\
\text { Note: V80, and V83 } \\
\text { are open } \\
\text { Note: altered to VV } \\
\text { numbers }\end{array}$ & Q10 - V38 to V49 \\
\hline & $\begin{array}{l}\text { Science in } \\
\text { society }\end{array}$ & & $\begin{array}{l}\text { Q14 - V113 } \\
\text { Q15 - V114 } \\
\text { Q16 - V115 to V126 } \\
\text { Note: V117, V118, } \\
\text { V120, V121, V123, } \\
\text { V124 and V126 are } \\
\text { open } \\
\text { Note: altered to VV } \\
\text { numbers }\end{array}$ & Q12 - V57 to V60 \\
\hline & Assessment & & $\begin{array}{l}\text { Q10 - V84 to V100 } \\
\text { Note: V91, V92, } \\
\text { V94, V95, V97, V98 } \\
\text { and V100 are open } \\
\text { Note: altered to VV } \\
\text { numbers }\end{array}$ & Q11 - V50 to V56 \\
\hline & $\begin{array}{l}\text { Science } \\
\text { practical work }\end{array}$ & & $\begin{array}{l}\text { Q11 - V101 } \\
\text { Q12 - V102 } \\
\text { Q13 -V103 to V112 } \\
\text { Note: V108, V109 } \\
\text { and V112 are open } \\
\text { Note: altered to VV } \\
\text { numbers }\end{array}$ & Q13 - V61 to V68 \\
\hline \multirow{4}{*}{ 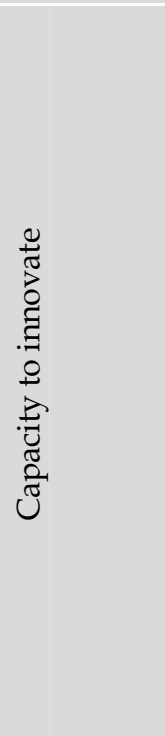 } & $\begin{array}{l}\text { Physical } \\
\text { resources }\end{array}$ & $\begin{array}{l}\text { Q7 - V41 } \\
\text { Q13 - V214 to V219 }\end{array}$ & $\begin{array}{l}\text { Q7 - V51 and V52 } \\
\text { Q24 - V208 to V226 } \\
\text { Q25 - V227 to V238 } \\
\text { Note: Provision and } \\
\text { effect interleafed }\end{array}$ & $\begin{array}{l}\text { Q8 and Q9 - V34 to } \\
\text { V37 } \\
\text { Q16 - V90 to V112 } \\
\text { Q17 - V113 to V116 }\end{array}$ \\
\hline & Teacher factors & $\begin{array}{l}\text { Q3 - V8 } \\
\text { Q4 - V9 to V20 } \\
\text { Note: Subject and } \\
\text { level interleafed } \\
\text { Q5 - V21 to V24 } \\
\text { Q8 - V42 to V62 } \\
\text { Q10 - V92 to } 115\end{array}$ & $\begin{array}{l}\text { Q3 - V8 } \\
\text { Q4 - V9 to V21 } \\
\text { Q5 - V23 to V31 } \\
\text { Q6 - V32 to V48 } \\
\text { Q8 - V53 to V73 } \\
\text { Q17 - V127 to V142 } \\
\text { Note: V136 is open } \\
\text { Q26 - V239 to V245 } \\
\text { Q27 - V246 to V252 }\end{array}$ & $\begin{array}{l}\text { Q3 - V8 to V16 } \\
\text { Q4 - V17 to V33 } \\
\text { Q14 - V69 to V78 }\end{array}$ \\
\hline & Learner factors & Q12 - V151 to V169 & Q28 - V253 to V271 & Q18 - V117 to V129 \\
\hline & $\begin{array}{l}\text { School ecology } \\
\text { and } \\
\text { management }\end{array}$ & & $\begin{array}{l}\text { Q18 - V143 to V154 } \\
\text { Q19 - V155 to V161 } \\
\text { Q21 - V172 to V185 }\end{array}$ & Q15 - V79 to V89 \\
\hline
\end{tabular}




\begin{tabular}{|c|c|c|c|c|}
\hline Construct & Sub-construct & $\begin{array}{l}\text { Teacher } \\
\text { questionnaire } 2001\end{array}$ & $\begin{array}{l}\text { Teacher } \\
\text { questionnaire } 2002\end{array}$ & $\begin{array}{l}\text { Teacher } \\
\text { questionnaire } 2003\end{array}$ \\
\hline \multirow{5}{*}{ 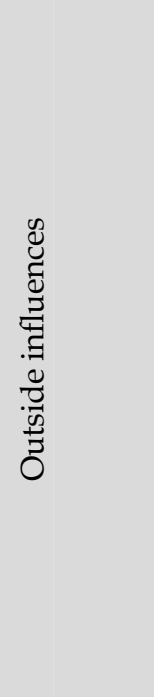 } & $\begin{array}{l}\text { Physical } \\
\text { resources }\end{array}$ & No items & No items & No items \\
\hline & $\begin{array}{l}\text { Professional } \\
\text { development }\end{array}$ & $\begin{array}{l}\text { Q13 - V178 to V194 } \\
\text { Note: filter } \\
\text { questions } \\
\text { interleafed }\end{array}$ & $\begin{array}{l}\text { Q20 - V162 to V170 } \\
\text { Q22 - V186 } \\
\text { Q23 - V17 to V207 } \\
\text { Note: V197, V198, } \\
\text { V201, V204 and } \\
\text { V207 are open }\end{array}$ & Q20 - V139 \\
\hline & Change forces & $\begin{array}{l}\text { Q13 - V170 to V177 } \\
\text { Note: V173, V174, } \\
\text { V176 and V177 } \\
\text { filter questions } \\
\text { Q13 - V195 to V198 } \\
\text { Q13 - V199 to V213 }\end{array}$ & & Q19 - V130 to V138 \\
\hline & Monitoring & No items & No items & $\mathrm{Q} 22$ - V154 to V159 \\
\hline & $\begin{array}{l}\text { Support to } \\
\text { learners }\end{array}$ & No items & No items & No items \\
\hline
\end{tabular}


APPENDIX 4 


\section{Factor Analysis of Capacity to Innovate variables}

Capacity to Innovate variables were factor analysed in 2002. Some of the variables were retained in the 2003 questionnaire. Their groupings are given below.

\section{Teacher Factors}

Teacher Factor 1 - Positive practices within teachers' schools - V71, V72 \& V76.

Teacher Factor 2 - In-service meeting with other teachers - V73, V74 \& V75.

Teacher Factor 3 - Teacher morale - V69 \& V70.

Teacher Factor 4 - Negative practices within teachers' schools - V77 \& V78.

\section{Learner Factors}

Learner Factor 1 - Positive attitude to the subject - V127 \& V128.

Learner Factor 2 - Home support of learning and language ability - V121, V122 \& V120.

Learner Factor 3 - Negative influences on learning - V117, V124, V125 \& V129.

Learner factor 4 - Learner physical environment - V118, V119, V120 \& V123.

\section{Physical Resources}

Written resources - V90 \& V92

Apparatus support materials - V94, V96 \& V98

Office machinery - V100 \& V106

Basic essentials - V102 \& V104

Library - V108

\section{$\underline{\text { School Ecology and Management }}$}

Management practices and consequences - V79, V80, V85, V86, V87, V88 and V89.

Shared management practices - V81, V82, V83 and V84. 
APPENDIX 5 
Case Study - A Field Guide

\section{Introduction}

This guide is designed to provide a framework for the case study of the implementation of C2005 in a Mpumalanga secondary school. A case study is a way of obtaining an in-depth understanding of the features and dynamics of one particular case from amongst many. It uses data collection methods such as observation, interviews and document collection. There are many secondary schools in Mpumlanga. The "case' in our situation will be one of these schools. We will not attempt to generalise our findings to all the other schools. Rather, we will attempt to gain an in-depth understanding of the processes and problems associated with the implementation of C2005 in the maths and science learning areas.

The guide gives an indication of the kind of data that needs to be collected and how the collection should occur. It assumes that the case study field worker will spend one week in the school involved in the case study. A case study is not a school visit. The field worker is expected to be at the school during the entire day for the entire week, and to become as much part of the school as possible. This guide will also provide the framework and guidelines on how the case study should be written up.

\section{Accessing a School}

The MDE will provide the director of the research project with a list of schools that represents an adequate sample of the schools in Mpumalanga. Each field worker will be able to select one of these schools in consultation with the director. To save on expenses, the school should be reasonably close to the place of residence of the field worker. However, in the case of a $\mathrm{CI}, \mathrm{it}$ should not be in the CI's district.

Contact the principal of the school a week or so before the proposed case study. If possible, visit the school one afternoon and meet with the principal and science/maths teachers. Explain the purpose of the visit, emphasizing that it is not an inspection, and the anonymity of the school and teachers will be ensured. Talk about the kinds of things you would like to do during the week. Make sure that the proposed time is suitable, in that it does not clash with events that might disrupt the normal flow of school activities. Also make sure that your visit has the cooperation of the school principal and the science and maths teachers. Emphasize again that the school and its staff will not be identified in the final report, and that all information will be treated with the strictest confidence. In the event of clear-cut reluctance on the part of a school to be part of the study, it might be better to select another school.

Explain to the principal and teachers that you will be writing up a case study report based on your visit. However, make the undertaking that you will give them a draft copy of the report before it is submitted to the director so as to enable them to correct any mistakes and to give their input on how the implementation of C2005 is proceeding.

While at the school, try to become part of the life of the school as much as possible. Mix with the teachers - have tea and lunch together. Maybe even attend a sports or cultural function. 


\section{The Framework}

The framework for the week-long case study is given in Tables 4 to 6 (pages 6 to 7). Note that the framework is built around the theoretical model described in Rogan and Grayson (2002). Hence the three constructs that will be investigated are:

1. The extent to which implementation of C2005 (and innovation in general) is occurring in classrooms. The Profile of Implementation is used here.

2. The capacity of the school to engage in innovation. The Profile of Capacity is used here.

3. The extent and kinds of support from outside the school. The Profile of Support is used here.

Data on these three constructs will be gathered in three ways; observation, interviews and from documents. Table 1 (see next page) describes how the data should be collected, from whom and how often. For example, under Implementation, the table specifies that each of the grade 8 and 9 science teachers should be observed at least once, and that one class e.g. science grade $9 \mathrm{C}$ should be observed for every science or maths lesson throughout the week.

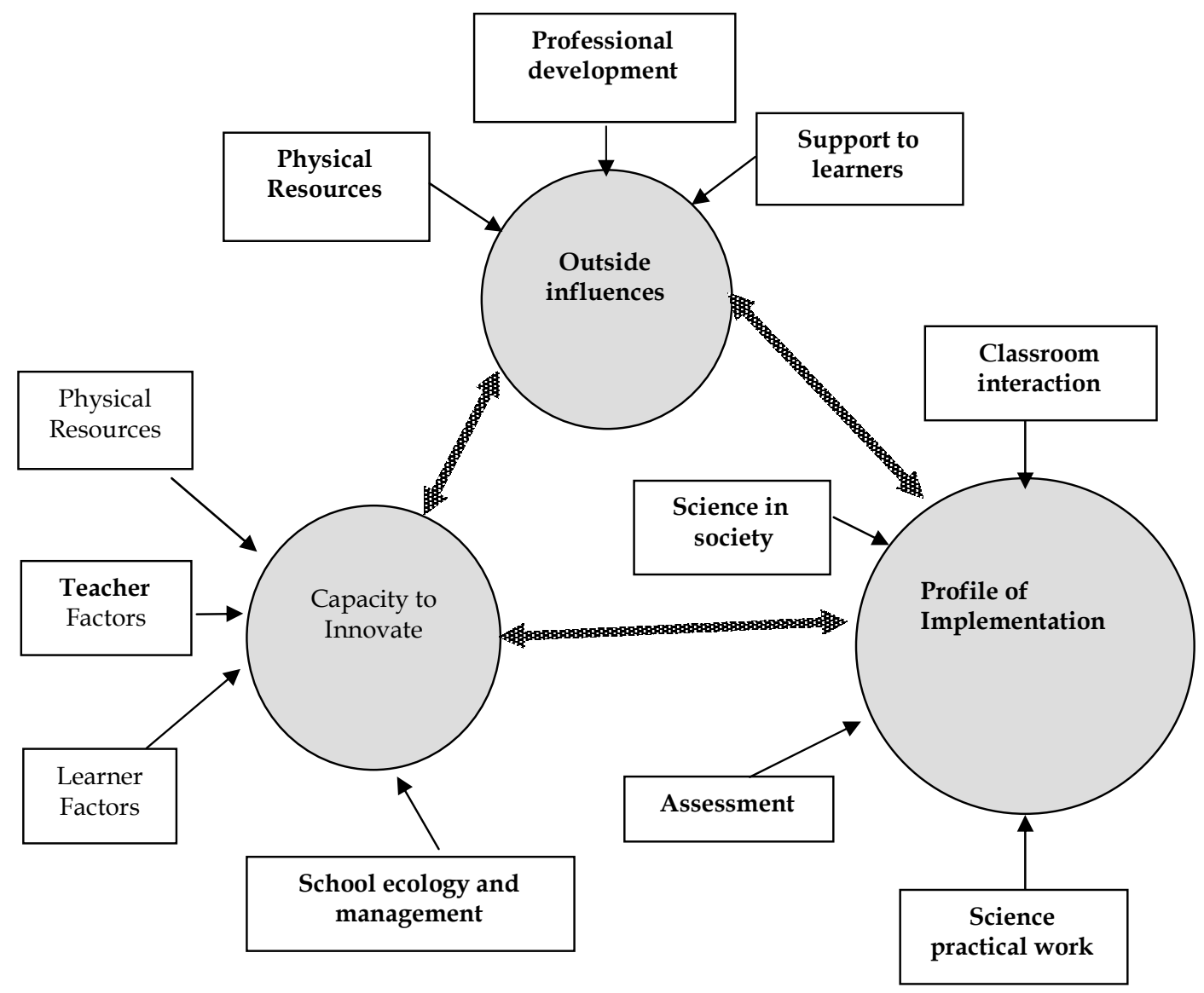

Figure 1: The Model on which the research is based

The dimensions and levels of these three constructs are given in tables 1 to 3 . 
Table 1

Profile of Implementation contextualised for the Natural Science and Mathematics Learning Area of

Curriculum 2005. (Note: Ignore the second column when used for maths)

\begin{tabular}{|c|c|c|c|c|}
\hline Level & $\begin{array}{l}\text { Classroom } \\
\text { interaction }\end{array}$ & $\begin{array}{l}\text { Science Practical } \\
\text { Work }\end{array}$ & $\begin{array}{l}\text { Science/Maths in } \\
\text { Society }\end{array}$ & Assessment \\
\hline 1 & $\begin{array}{l}\text { Teacher: } \\
\text { Presents content in a } \\
\text { well organised, } \\
\text { correct and well } \\
\text { sequenced manner, } \\
\text { based on a well } \\
\text { designed lesson plan. } \\
\text { Provides adequate } \\
\text { notes. } \\
\text { Uses textbook } \\
\text { effectively. } \\
\text { Engages learners } \\
\text { with questions. } \\
\text { Learners: } \\
\text { Stay attentive and } \\
\text { engaged. } \\
\text { Respond to and } \\
\text { initiate questions. }\end{array}$ & $\begin{array}{l}\text { Teacher uses } \\
\text { classroom } \\
\text { demonstrations to } \\
\text { help develop } \\
\text { concepts. } \\
\text { Teacher uses } \\
\text { specimens found } \\
\text { in the local } \\
\text { environment to } \\
\text { illustrate lessons. }\end{array}$ & $\begin{array}{l}\text { Teacher uses } \\
\text { examples and } \\
\text { applications from } \\
\text { everyday life to } \\
\text { illustrate } \\
\text { scientific/maths } \\
\text { concepts. } \\
\text { Learners ask } \\
\text { questions about } \\
\text { science in the context } \\
\text { of everyday life. }\end{array}$ & $\begin{array}{l}\text { Written tests are } \\
\text { given that cover the } \\
\text { topic adequately. } \\
\text { While most } \\
\text { questions are of the } \\
\text { recall type, some } \\
\text { require higher } \\
\text { order thinking. } \\
\text { Tests are marked } \\
\text { and returned } \\
\text { promptly. }\end{array}$ \\
\hline 2 & $\begin{array}{l}\text { Teacher: } \\
\text { Textbooks are used } \\
\text { along with other } \\
\text { resources. } \\
\text { Engages learners } \\
\text { with questions that } \\
\text { encourage in depth } \\
\text { thinking. } \\
\text { Learners: } \\
\text { Use additional (to } \\
\text { text book) sources of } \\
\text { information in } \\
\text { compiling notes. } \\
\text { Engage in } \\
\text { meaningful group } \\
\text { work. } \\
\text { On own initiative, } \\
\text { offer a contribution to } \\
\text { the lesson. }\end{array}$ & $\begin{array}{l}\text { Teacher uses } \\
\text { demonstrations to } \\
\text { promote a limited } \\
\text { form of inquiry. } \\
\text { Some learners } \\
\text { assist in planning } \\
\text { and performing } \\
\text { the } \\
\text { demonstrations. } \\
\text { Learners } \\
\text { participate in } \\
\text { closed (cook-book) } \\
\text { practical work. } \\
\text { Learners } \\
\text { communicate data } \\
\text { using graphs and } \\
\text { tables. }\end{array}$ & $\begin{array}{l}\text { Teacher bases a } \\
\text { lesson (or lessons) on } \\
\text { a specific problem or } \\
\text { issue faced by the } \\
\text { local community. } \\
\text { Teacher assists } \\
\text { learners to explore } \\
\text { the explanations of } \\
\text { scientific/maths } \\
\text { phenomena by } \\
\text { different cultural } \\
\text { groups. }\end{array}$ & $\begin{array}{l}\text { Written tests } \\
\text { include at least } 50 \% \\
\text { of the questions that } \\
\text { require } \\
\text { comprehension, } \\
\text { application and } \\
\text { analysis. } \\
\text { Some of the } \\
\text { questions are based } \\
\text { on practical work. }\end{array}$ \\
\hline
\end{tabular}




\begin{tabular}{|c|c|c|c|c|}
\hline Level & $\begin{array}{l}\text { Classroom } \\
\text { interaction }\end{array}$ & $\begin{array}{l}\text { Science Practical } \\
\text { Work }\end{array}$ & $\begin{array}{l}\text { Science/Maths in } \\
\text { Society }\end{array}$ & Assessment \\
\hline 3 & $\begin{array}{l}\text { Teacher: } \\
\text { Probes learners' prior } \\
\text { knowledge. } \\
\text { Structures learning } \\
\text { activities along "good } \\
\text { practice" lines } \\
\text { (knowledge is } \\
\text { constructed, is } \\
\text { relevant, and is based } \\
\text { on problem solving } \\
\text { techniques.) } \\
\text { Introduces learners to } \\
\text { the evolving nature } \\
\text { of scientific / maths } \\
\text { knowledge. } \\
\text { Learners: } \\
\text { Engage in minds-on } \\
\text { learning activities. } \\
\text { Make own notes on } \\
\text { the concepts learned } \\
\text { from doing these } \\
\text { activities. }\end{array}$ & $\begin{array}{l}\text { Teacher designs } \\
\text { practical work in } \\
\text { such a way as to } \\
\text { encourage learner } \\
\text { discovery of } \\
\text { information. } \\
\text { Learners perform } \\
\text { 'guided discovery' } \\
\text { type practical } \\
\text { work in small } \\
\text { groups, engaging } \\
\text { in hands-on } \\
\text { activities. } \\
\text { Learners can write } \\
\text { a scientific report } \\
\text { in which they can } \\
\text { justify their } \\
\text { conclusions in } \\
\text { terms of the data } \\
\text { collected. }\end{array}$ & $\begin{array}{l}\text { Learners actively } \\
\text { investigate the } \\
\text { application of } \\
\text { science/maths and } \\
\text { technology in their } \\
\text { own environment, } \\
\text { mainly by means of } \\
\text { data gathering } \\
\text { methods such as } \\
\text { surveys. Examples } \\
\text { here might include } \\
\text { an audit of energy } \\
\text { use or career } \\
\text { opportunities that } \\
\text { require a } \\
\text { scientific/maths } \\
\text { background. }\end{array}$ & $\begin{array}{l}\text { Written tests } \\
\text { include questions } \\
\text { based on seen or } \\
\text { unseen 'guided } \\
\text { discovery' type } \\
\text { activities. } \\
\text { Assessment is } \\
\text { based on more than } \\
\text { written tests. Other } \\
\text { forms of assessment } \\
\text { might include: } \\
\text { reports on activities } \\
\text { undertaken; } \\
\text { creation of charts } \\
\text { and improvised } \\
\text { apparatus; } \\
\text { reports on extra } \\
\text { reading } \\
\text { assignments. }\end{array}$ \\
\hline 4 & $\begin{array}{l}\text { Learners: } \\
\text { Take major } \\
\text { responsibility for } \\
\text { their own learning; } \\
\text { partake in the } \\
\text { planning and } \\
\text { assessment of their } \\
\text { own learning. } \\
\text { Undertake long term } \\
\text { and community- } \\
\text { based investigations } \\
\text { projects. } \\
\text { Teacher: } \\
\text { Facilitates learners as } \\
\text { they design and } \\
\text { undertake long-term } \\
\text { investigations and } \\
\text { projects. } \\
\text { Assists learners to } \\
\text { weigh up the merits } \\
\text { of different theories } \\
\text { that attempt to } \\
\text { explain the same } \\
\text { phenomena. }\end{array}$ & $\begin{array}{l}\text { Learners design } \\
\text { and do their own } \\
\text { 'open' } \\
\text { investigations. } \\
\text { They reflect on the } \\
\text { quality of the } \\
\text { design and } \\
\text { collected data, and } \\
\text { make } \\
\text { improvements. } \\
\text { Learners can } \\
\text { interpret data in } \\
\text { support of } \\
\text { competing theories } \\
\text { or explanations. }\end{array}$ & $\begin{array}{l}\text { Learners actively } \\
\text { undertake a project } \\
\text { in their local } \\
\text { community in which } \\
\text { they apply science } \\
\text { /maths to tackle a } \\
\text { specific problem or } \\
\text { to meet a specific } \\
\text { need. An example } \\
\text { might be on growing } \\
\text { a new type of crop to } \\
\text { increase the income } \\
\text { of the community. } \\
\text { Learners explore the } \\
\text { long term effects of } \\
\text { community projects. } \\
\text { For example, a } \\
\text { project may have a } \\
\text { short-term benefit } \\
\text { but result in long } \\
\text { term detrimental } \\
\text { effects. }\end{array}$ & $\begin{array}{l}\text { Performance on } \\
\text { open investigations } \\
\text { and community - } \\
\text { based projects are } \\
\text { included in the final } \\
\text { assessment. } \\
\text { Learners create } \\
\text { portfolios to } \\
\text { represent their } \\
\text { 'best' work. }\end{array}$ \\
\hline
\end{tabular}


Table 2:

Profile of the Capacity to Support Innovation

\begin{tabular}{|c|c|c|c|c|}
\hline Level & $\begin{array}{l}\text { Physical } \\
\text { Resources }\end{array}$ & Teacher factors & Learner factors & $\begin{array}{l}\text { School ecology and } \\
\text { management }\end{array}$ \\
\hline 1 & $\begin{array}{l}\text { Basic buildings } \\
\text { - classrooms } \\
\text { and one office, } \\
\text { but in poor } \\
\text { condition. } \\
\text { Toilets available } \\
\text { Some textbooks } \\
\text { - not enough for } \\
\text { all }\end{array}$ & $\begin{array}{l}\text { Teacher is under- } \\
\text { qualified for } \\
\text { position, but does } \\
\text { have a } \\
\text { professional } \\
\text { qualification }\end{array}$ & $\begin{array}{l}\text { Learners have } \\
\text { some } \\
\text { proficiency in } \\
\text { language of } \\
\text { instruction, but } \\
\text { several grades } \\
\text { below grade } \\
\text { level }\end{array}$ & $\begin{array}{l}\text { Management: A timetable, } \\
\text { class lists and other } \\
\text { routines are in evidence. } \\
\text { The presence of the } \\
\text { principal is felt in the school } \\
\text { at least half the time, and } \\
\text { staff meetings are held at } \\
\text { times } \\
\text { Ecology: School functions } \\
\text { i.e. teaching and learning } \\
\text { occur most of the time, } \\
\text { albeit erratically. } \\
\text { School is secure and access } \\
\text { is denied to unauthorized } \\
\text { personnel }\end{array}$ \\
\hline 2 & $\begin{array}{l}\text { Adequate basic } \\
\text { buildings in } \\
\text { good condition } \\
\text { Suitable } \\
\text { furniture - } \\
\text { adequate and in } \\
\text { good condition } \\
\text { Electricity in at } \\
\text { least one room } \\
\text { Textbooks for } \\
\text { all } \\
\text { Some apparatus } \\
\text { for science }\end{array}$ & $\begin{array}{l}\text { Teacher has the } \\
\text { minimum } \\
\text { qualification for } \\
\text { position } \\
\text { Teacher attends } \\
\text { school/classes } \\
\text { regularly } \\
\text { Teacher is } \\
\text { motivated and } \\
\text { diligent. Enjoys } \\
\text { his/her work } \\
\text { Teacher } \\
\text { participates in } \\
\text { professional } \\
\text { development } \\
\text { activities } \\
\text { Teacher has a } \\
\text { good relationship } \\
\text { with and } \\
\text { treatment of } \\
\text { learners }\end{array}$ & $\begin{array}{l}\text { Learners are } \\
\text { reasonably } \\
\text { proficient in } \\
\text { language of } \\
\text { instruction } \\
\text { Learners attend } \\
\text { school on a } \\
\text { regular basis } \\
\text { Learners are } \\
\text { well nourished } \\
\text { Learners are } \\
\text { given adequate } \\
\text { time away from } \\
\text { home } \\
\text { responsibilities } \\
\text { to do school } \\
\text { work }\end{array}$ & $\begin{array}{l}\text { Management: Principal is } \\
\text { present at school most of } \\
\text { the time and is in regular } \\
\text { contact with his/her staff } \\
\text { Timetable properly } \\
\text { implemented } \\
\text { Extramural activities are } \\
\text { organized in such a way } \\
\text { that they rarely interfere } \\
\text { with scheduled classes } \\
\text { Teachers/learners who } \\
\text { shirk their duties or display } \\
\text { deviant behaviour are held } \\
\text { accountable } \\
\text { Ecology: Responsibility for } \\
\text { making the school function } \\
\text { is shared by management, } \\
\text { teachers and learners to a } \\
\text { limited extent. } \\
\text { A School Governing Body } \\
\text { is in existence. } \\
\text { Schools functions all the } \\
\text { time i.e. learning and } \\
\text { teaching always take place } \\
\text { as scheduled }\end{array}$ \\
\hline 3 & $\begin{array}{l}\text { Good buildings, } \\
\text { with enough } \\
\text { classrooms and } \\
\text { a science room } \\
\text { Electricity in all } \\
\text { rooms } \\
\text { Running water } \\
\text { Textbooks for } \\
\text { all pupils and }\end{array}$ & $\begin{array}{l}\text { Teacher is } \\
\text { qualified for } \\
\text { position and has a } \\
\text { sound } \\
\text { understanding of } \\
\text { subject matter } \\
\text { Teacher is an } \\
\text { active participant } \\
\text { in professional }\end{array}$ & $\begin{array}{l}\text { Learners are } \\
\text { proficient in } \\
\text { language of } \\
\text { instruction } \\
\text { Learners have } \\
\text { access to quiet, } \\
\text { safe place to } \\
\text { study } \\
\text { Learners come }\end{array}$ & $\begin{array}{l}\text { Management: Principal } \\
\text { takes strong leadership } \\
\text { role, is very visible during } \\
\text { schools hours } \\
\text { Teachers and learners play } \\
\text { an active role in school } \\
\text { management } \\
\text { Ecology: Everyone in the } \\
\text { school is committed to }\end{array}$ \\
\hline
\end{tabular}




\begin{tabular}{|c|c|c|c|c|}
\hline \multirow[t]{2}{*}{ Level } & $\begin{array}{l}\text { Physical } \\
\text { Resources }\end{array}$ & Teacher factors & Learner factors & $\begin{array}{l}\text { School ecology and } \\
\text { management }\end{array}$ \\
\hline & $\begin{array}{l}\text { teachers } \\
\text { Sufficient } \\
\text { science } \\
\text { apparatus } \\
\text { Secure premises } \\
\text { Well kept } \\
\text { grounds }\end{array}$ & $\begin{array}{l}\text { development } \\
\text { activities } \\
\text { Conscientious } \\
\text { attendance of } \\
\text { class by teacher } \\
\text { Teacher makes an } \\
\text { extra effort to } \\
\text { improve teaching }\end{array}$ & $\begin{array}{l}\text { from a } \\
\text { supportive } \\
\text { home } \\
\text { environment } \\
\text { Learners can } \\
\text { afford textbooks } \\
\text { and extra } \\
\text { lessons } \\
\text { Parents show } \\
\text { interest in their } \\
\text { children's } \\
\text { progress }\end{array}$ & $\begin{array}{l}\quad \text { making it work } \\
\text { Parents play active role in } \\
\text { School Governing Bodies } \\
\text { and in supporting the } \\
\text { school in general }\end{array}$ \\
\hline 4 & $\begin{array}{l}\text { Excellent } \\
\text { buildings } \\
\text { One or more } \\
\text { well equipped } \\
\text { science } \\
\text { laboratory } \\
\text { Library or } \\
\text { resource centre } \\
\text { Adequate } \\
\text { curriculum } \\
\text { materials other } \\
\text { than textbooks } \\
\text { Good teaching } \\
\text { and learning } \\
\text { resources (e.g. } \\
\text { computers, } \\
\text { models) } \\
\text { Attractive } \\
\text { grounds } \\
\text { Good copying } \\
\text { facilities }\end{array}$ & $\begin{array}{l}\text { Teacher is over- } \\
\text { qualified for } \\
\text { position and has } \\
\text { an excellent } \\
\text { knowledge of } \\
\text { content matter } \\
\text { Teacher has an } \\
\text { extraordinary } \\
\text { commitment to } \\
\text { teaching } \\
\text { Teacher shows } \\
\text { willingness to } \\
\text { change, improvise } \\
\text { and collaborate, } \\
\text { and has a vision } \\
\text { of innovation } \\
\text { Teacher shows } \\
\text { local and national } \\
\text { leadership in } \\
\text { professional } \\
\text { development } \\
\text { activities }\end{array}$ & $\begin{array}{l}\text { Learners are } \\
\text { fluent in the } \\
\text { language of } \\
\text { instruction } \\
\text { Learners take } \\
\text { responsibility } \\
\text { for their own } \\
\text { learning } \\
\text { Learners are } \\
\text { willing to try } \\
\text { new kinds of } \\
\text { learning }\end{array}$ & $\begin{array}{l}\text { Ecology: There is a shared } \\
\text { vision } \\
\text { The school plans for, } \\
\text { supports and monitors } \\
\text { change } \\
\text { Collaboration of all } \\
\text { stakeholders is encouraged } \\
\text { and practiced } \\
\text { Management: There is a } \\
\text { visionary, but } \\
\text { participatory, leadership at } \\
\text { the school }\end{array}$ \\
\hline
\end{tabular}


Table 3

Profile of Outside Support

\begin{tabular}{|c|c|c|c|c|c|}
\hline \multirow[t]{2}{*}{ Level } & \multicolumn{3}{|c|}{ Types of encouragement and support } & \multirow[b]{2}{*}{$\begin{array}{l}\text { Dominant } \\
\text { change force } \\
\text { evoked by } \\
\text { agency }\end{array}$} & \multirow[b]{2}{*}{$\begin{array}{l}\text { Monitoring } \\
\text { mechanisms } \\
\text { and } \\
\text { accountability }\end{array}$} \\
\hline & $\begin{array}{l}\text { Physical } \\
\text { Resources } \\
\text { Categories of } \\
\text { resources: } \\
\text { Buildings, } \\
\text { apparatus, } \\
\text { curriculum } \\
\text { materials (print } \\
\text { and electronic), } \\
\text { computers, etc. }\end{array}$ & $\begin{array}{l}\text { Design of } \\
\text { Professional } \\
\text { Development }\end{array}$ & $\begin{array}{l}\text { Direct support } \\
\text { to learners }\end{array}$ & & \\
\hline 1 & $\begin{array}{l}\text { Provision } \\
\text { supplements } \\
\text { what exists, but } \\
\text { not enough to } \\
\text { support the } \\
\text { intended } \\
\text { changes. Provi- } \\
\text { sion is in one } \\
\text { category only. }\end{array}$ & $\begin{array}{l}\text { Information on } \\
\text { policy and } \\
\text { expected changes } \\
\text { are presented to } \\
\text { school based } \\
\text { personnel. } \\
\text { Typical mode is } \\
\text { short, one shot } \\
\text { workshop. }\end{array}$ & $\begin{array}{l}\text { Provision of } \\
\text { basic needs, } \\
\text { such as } \\
\text { lunches and } \\
\text { places to } \\
\text { study. }\end{array}$ & $\begin{array}{l}\text { Bureaucratic. } \\
\text { Change is } \\
\text { brought about } \\
\text { by top down } \\
\text { directives to } \\
\text { bring about } \\
\text { change. }\end{array}$ & $\begin{array}{l}\text { Inspections by } \\
\text { authorities are } \\
\text { undertaken }\end{array}$ \\
\hline 2 & $\begin{array}{l}\text { Provision } \\
\text { completely } \\
\text { covers what is } \\
\text { required to } \\
\text { effect the } \\
\text { intended } \\
\text { change in one } \\
\text { category, or } \\
\text { partly sufficient } \\
\text { in two } \\
\text { categories. }\end{array}$ & $\begin{array}{l}\text { Examples of 'new' } \\
\text { practices as } \\
\text { suggested by the } \\
\text { policies are } \\
\text { presented to } \\
\text { school based } \\
\text { personnel, who } \\
\text { are given an } \\
\text { opportunity to } \\
\text { engage in these } \\
\text { practices in a } \\
\text { simulated } \\
\text { situation. } \\
\text { Typical mode is a } \\
\text { series of short } \\
\text { workshops lasting } \\
\text { for one year. }\end{array}$ & $\begin{array}{l}\text { Basic } \\
\text { academic } \\
\text { needs are } \\
\text { catered for in } \\
\text { the form of } \\
\text { extra lessons. }\end{array}$ & $\begin{array}{l}\text { Charismatic } \\
\text { Change is } \\
\text { brought about } \\
\text { by top down } \\
\text { inspiration and } \\
\text { encouragement }\end{array}$ & $\begin{array}{l}\text { Inspections } \\
\text { are } \\
\text { undertaken in } \\
\text { collaboration } \\
\text { with school- } \\
\text { based } \\
\text { personnel. }\end{array}$ \\
\hline 3 & $\begin{array}{l}\text { Provision } \\
\text { completely } \\
\text { covers what is } \\
\text { required to } \\
\text { effect the } \\
\text { intended } \\
\text { change in two } \\
\text { categories, or } \\
\text { partly sufficient } \\
\text { in three } \\
\text { categories. }\end{array}$ & $\begin{array}{l}\text { Professional } \\
\text { development is } \\
\text { designed by } \\
\text { school based } \\
\text { personnel } \\
\text { depending on } \\
\text { which new } \\
\text { practices they } \\
\text { wish to } \\
\text { implement, and } \\
\text { implemented } \\
\text { using both inside } \\
\text { and outside } \\
\text { support. }\end{array}$ & $\begin{array}{l}\text { Enriched } \\
\text { academic } \\
\text { needs are } \\
\text { catered for in } \\
\text { the form of } \\
\text { field trips and } \\
\text { other } \\
\text { enrichment } \\
\text { type activities. }\end{array}$ & $\begin{array}{l}\text { Professional } \\
\text { Change is } \\
\text { brought about } \\
\text { by encouraging } \\
\text { role players to } \\
\text { embrace codes } \\
\text { of conduct and } \\
\text { standards of } \\
\text { teaching and } \\
\text { learning }\end{array}$ & $\begin{array}{l}\text { School-based } \\
\text { personnel } \\
\text { monitor own } \\
\text { progress, but } \\
\text { report to } \\
\text { authorities }\end{array}$ \\
\hline
\end{tabular}




\begin{tabular}{|c|c|c|c|c|c|}
\hline \multirow[t]{3}{*}{ Level } & \multicolumn{3}{|c|}{ Types of encouragement and support } & \multirow{2}{*}{$\begin{array}{l}\text { Dominant } \\
\text { change force } \\
\text { evoked by } \\
\text { agency }\end{array}$} & \multirow{2}{*}{$\begin{array}{l}\text { Monitoring } \\
\text { mechanisms } \\
\text { and } \\
\text { accountability }\end{array}$} \\
\hline & $\begin{array}{l}\text { Physical } \\
\text { Resources } \\
\text { Categories of } \\
\text { resources: } \\
\text { Buildings, } \\
\text { apparatus, } \\
\text { curriculum } \\
\text { materials (print } \\
\text { and electronic), } \\
\text { computers, etc. }\end{array}$ & $\begin{array}{l}\text { Design of } \\
\text { Professional } \\
\text { Development }\end{array}$ & $\begin{array}{c}\text { Direct support } \\
\text { to learners }\end{array}$ & & \\
\hline & & $\begin{array}{l}\text { Typical mode } \\
\text { consists of both } \\
\text { external and } \\
\text { school-based } \\
\text { INSET for two to } \\
\text { three years. }\end{array}$ & & & \\
\hline 4 & $\begin{array}{l}\text { Provision } \\
\text { completely } \\
\text { covers what is } \\
\text { required to } \\
\text { effect the } \\
\text { intended } \\
\text { change in three } \\
\text { categories, or } \\
\text { covers two } \\
\text { categories and } \\
\text { is partly } \\
\text { sufficient in all } \\
\text { four categories. }\end{array}$ & $\begin{array}{l}\text { Communities of } \\
\text { practice take full } \\
\text { responsibility for } \\
\text { their own } \\
\text { continued } \\
\text { professional } \\
\text { growth, and for } \\
\text { school governance } \\
\text { and curriculum } \\
\text { implementation, } \\
\text { calling on outside } \\
\text { support as } \\
\text { appropriate. } \\
\text { Typical mode } \\
\text { consists of } \\
\text { ongoing school- } \\
\text { based and } \\
\text { directed } \\
\text { professional } \\
\text { INSET. }\end{array}$ & $\begin{array}{l}\text { Complete } \\
\text { academic and } \\
\text { personal } \\
\text { support is } \\
\text { provided, } \\
\text { usually in the } \\
\text { form of } \\
\text { bursaries. }\end{array}$ & $\begin{array}{l}\text { Learning } \\
\text { Community } \\
\text { Change is } \\
\text { brought about } \\
\text { by developing } \\
\text { communities } \\
\text { that develop } \\
\text { shared values } \\
\text { and goals } \\
\text { regarding } \\
\text { educational } \\
\text { practice and a } \\
\text { commitment to } \\
\text { put these into } \\
\text { practice. }\end{array}$ & $\begin{array}{l}\text { All } \\
\text { monitoring is } \\
\text { undertaken by } \\
\text { school-based } \\
\text { personnel. }\end{array}$ \\
\hline
\end{tabular}


Table 4

Case study-framework: profile of Implementation

\begin{tabular}{|c|c|c|c|c|}
\hline $\begin{array}{c}\text { Instrument / } \\
\text { Tools }\end{array}$ & $\begin{array}{l}\text { Classroom } \\
\text { interaction }\end{array}$ & $\begin{array}{c}\text { Science Practical } \\
\text { Work }\end{array}$ & Science in Society & Assessment \\
\hline \multirow[t]{4}{*}{ Observation } & $\begin{array}{l}\text { Observe all grade } 8 \\
\text { and } 9 \text { science and } \\
\text { maths learners and } \\
\text { teachers }\end{array}$ & $\begin{array}{l}\text { Observe all grade } 8 \\
\text { and } 9 \text { science and } \\
\text { maths learners and } \\
\text { teachers }\end{array}$ & $\begin{array}{l}\text { Observe all grade } 8 \\
\text { and } 9 \text { science and } \\
\text { maths learners and } \\
\text { teachers }\end{array}$ & \multirow{2}{*}{$\begin{array}{l}\text { Observe if } \\
\text { assessment } \\
\text { occurs as part } \\
\text { of normal } \\
\text { schedule. Do } \\
\text { not request } \\
\text { assessment to } \\
\text { be done } \\
\text { specially for an } \\
\text { observation }\end{array}$} \\
\hline & $\begin{array}{l}\text { Follow one teacher } \\
\text { for one class (class } \\
\text { continuously) on a } \\
\text { daily basis through } \\
\text { the week }\end{array}$ & $\begin{array}{l}\text { Follow one teacher } \\
\text { for one class (class } \\
\text { continuously) on a } \\
\text { daily basis through } \\
\text { the week }\end{array}$ & $\begin{array}{l}\text { Follow one teacher } \\
\text { for one class (class } \\
\text { continuously) on a } \\
\text { daily basis through } \\
\text { the week }\end{array}$ & \\
\hline & $\begin{array}{l}\text { Use the extended } \\
\text { profile of } \\
\text { implementation to } \\
\text { assess classroom } \\
\text { practice }\end{array}$ & $\begin{array}{l}\text { Use the extended } \\
\text { profile of } \\
\text { implementation to } \\
\text { assess classroom } \\
\text { practice }\end{array}$ & $\begin{array}{l}\text { Use the extended } \\
\text { profile of } \\
\text { implementation to } \\
\text { assess classroom } \\
\text { practice }\end{array}$ & \\
\hline & $\begin{array}{l}\text { Record each lesson } \\
\text { on the observation } \\
\text { sheet supplied. If } \\
\text { possible record } \\
\text { some of the lessons } \\
\text { on video }\end{array}$ & $\begin{array}{l}\text { Record each lesson } \\
\text { on the observation } \\
\text { sheet supplied. If } \\
\text { possible record } \\
\text { some of the lessons } \\
\text { on video }\end{array}$ & $\begin{array}{l}\text { Record each lesson } \\
\text { on the observation } \\
\text { sheet supplied. If } \\
\text { possible record } \\
\text { some of the lessons } \\
\text { on video }\end{array}$ & \\
\hline Interview & $\begin{array}{l}\text { Individual } \\
\text { interview: } \\
1 \text { maths teacher } \\
\text { grade } 8 \\
1 \text { science teacher } \\
\text { grade } 8 \\
1 \text { maths teacher } \\
\text { grade } 9 \\
1 \text { science teacher } \\
\text { grade9 } \\
\text { Group interview: } \\
5 \text { maths learners } \\
\text { grade } 8 \\
5 \text { science learners } \\
\text { grade } 8 \\
5 \text { maths learners } \\
\text { grade } 9 \\
5 \text { science learners } \\
\text { grade } 9\end{array}$ & $\begin{array}{l}\text { Individual } \\
\text { interview: } \\
1 \text { maths teacher } \\
\text { grade } 8 \\
1 \text { science teacher } \\
\text { grade } 8 \\
1 \text { maths teacher } \\
\text { grade } 9 \\
1 \text { science teacher } \\
\text { grade9 } \\
\text { Group interview: } \\
5 \text { maths learners } \\
\text { grade } 8 \\
5 \text { science learners } \\
\text { grade } 8 \\
5 \text { maths learners } \\
\text { grade } 9 \\
5 \text { science learners } \\
\text { grade } 9\end{array}$ & $\begin{array}{l}\text { Individual } \\
\text { interview: } \\
1 \text { maths teacher } \\
\text { grade } 8 \\
1 \text { science teacher } \\
\text { grade } 8 \\
1 \text { maths teacher } \\
\text { grade } 9 \\
1 \text { science teacher } \\
\text { grade9 } \\
\text { Group interview: } \\
5 \text { maths learners } \\
\text { grade } 8 \\
5 \text { science learners } \\
\text { grade } 8 \\
5 \text { maths learners } \\
\text { grade } 9 \\
5 \text { science learners } \\
\text { grade } 9\end{array}$ & $\begin{array}{l}\text { Interview } \\
\text { questions for } \\
\text { teachers and } \\
\text { learners on } \\
\text { assessment }\end{array}$ \\
\hline
\end{tabular}




\begin{tabular}{|l|l|l|l|l|}
\hline $\begin{array}{c}\text { Instrument } \\
\text { Tools }\end{array}$ & $\begin{array}{c}\text { Classroom } \\
\text { interaction }\end{array}$ & $\begin{array}{c}\text { Science Practical } \\
\text { Work }\end{array}$ & Science in Society & \multicolumn{1}{|c|}{ Assessment } \\
\hline Documents & $\begin{array}{l}\text { Collect lesson plans } \\
\text { and worksheets }\end{array}$ & $\begin{array}{l}\text { Collect lesson plans } \\
\text { and worksheets }\end{array}$ & $\begin{array}{l}\text { Collect lesson plans } \\
\text { and worksheets }\end{array}$ & $\begin{array}{l}\text { Collect assess- } \\
\text { ment instru- } \\
\text { ments such as: } \\
\text { tests, tasks, } \\
\text { reporting docu- } \\
\text { ments, term } \\
\text { and promotion } \\
\text { and }\end{array}$ \\
& & & \\
marks
\end{tabular}


Table 5

Case study-framework: profile of the capacity to support innovation

\begin{tabular}{|c|c|c|c|c|}
\hline $\begin{array}{c}\text { Instrument / } \\
\text { Tools }\end{array}$ & Physical Resources & Teacher factors & Learner factors & $\begin{array}{c}\text { School ecology } \\
\text { and } \\
\text { management }\end{array}$ \\
\hline Observation & $\begin{array}{l}\text { What physical } \\
\text { resources are in the } \\
\text { school? } \\
\text { See observation sheet } \\
\text { provided }\end{array}$ & $\begin{array}{l}\text { General impressions } \\
\text { during the week on: } \\
\text { Motivation } \\
\text { Enthusiasm } \\
\text { Drive } \\
\text { Dedication } \\
\text { See observation sheet } \\
\text { provided }\end{array}$ & $\begin{array}{c}\text { General impressions } \\
\text { during the week on: } \\
\text { Motivation } \\
\text { Study habits } \\
\text { Enthusiasm } \\
\text { Dedication } \\
\text { See observation } \\
\text { sheet provided }\end{array}$ & $\begin{array}{l}\text { General } \\
\text { impressions } \\
\text { See observation } \\
\text { sheet provided }\end{array}$ \\
\hline Interview & $\begin{array}{l}\text { Interview all grade } 8 \\
\text { and } 9 \text { science and } \\
\text { maths teachers }\end{array}$ & $\begin{array}{l}\text { Interview principal } \\
\text { and all grade } 8 \text { and } 9 \\
\text { science and maths } \\
\text { teachers. }\end{array}$ & $\begin{array}{l}\text { Interview learners, } \\
\text { teachers and } \\
\text { principal }\end{array}$ & $\begin{array}{l}\text { Interview } \\
\text { teachers and } \\
\text { principal }\end{array}$ \\
\hline Documents & & $\begin{array}{l}\text { Qualifications of } \\
\text { teachers from school } \\
\text { report }\end{array}$ & $\begin{array}{l}\text { Documents on: } \\
\text { Drop out rate } \\
\text { Pass rate in } \\
\text { grade } 9\end{array}$ & $\begin{array}{l}\text { Documents such } \\
\text { as: } \\
\\
\text { Timetable } \\
\text { Routines } \\
\text { Minutes of } \\
\text { meetings } \\
\text { Policy } \\
\text { documents } \\
\text { Admission } \\
\text { statement }\end{array}$ \\
\hline
\end{tabular}


Table 6:

Case study-framework: profile of outside support

\begin{tabular}{|c|c|c|c|c|}
\hline $\begin{array}{c}\text { Instrument / } \\
\text { Tools }\end{array}$ & Physical Resources & $\begin{array}{l}\text { Professional } \\
\text { Development }\end{array}$ & Support to learners & $\begin{array}{c}\text { Monitoring } \\
\text { mechanisms/ } \\
\text { accountability }\end{array}$ \\
\hline Observation & $\begin{array}{l}\text { General impressions } \\
\text { during the week. }\end{array}$ & $\begin{array}{l}\text { What kind of } \\
\text { professional } \\
\text { development can you } \\
\text { observe? Describe } \\
\text { general impressions. }\end{array}$ & $\begin{array}{l}\text { General impressions } \\
\text { during the week. } \\
\text { (Refer to the levels of } \\
\text { support in profile.) }\end{array}$ & $\begin{array}{l}\text { General } \\
\text { impressions }\end{array}$ \\
\hline Interview & $\begin{array}{l}\text { Interview teachers } \\
\text { and principal about } \\
\text { what is given this } \\
\text { school year. }\end{array}$ & $\begin{array}{l}\text { Interview teachers and } \\
\text { principal about the } \\
\text { professional } \\
\text { development in the } \\
\text { school. }\end{array}$ & $\begin{array}{l}\text { Interview teachers } \\
\text { and learners about } \\
\text { how the learners are } \\
\text { supported }\end{array}$ & $\begin{array}{l}\text { Interview } \\
\text { teachers and } \\
\text { principal about } \\
\text { the changes of } \\
\text { the curriculum. } \\
\text { Voluntary? } \\
\text { Demand? } \\
\text { How do they } \\
\text { deal with it? }\end{array}$ \\
\hline Documents & & $\begin{array}{l}\text { Documents on the } \\
\text { reporting of } \\
\text { professional } \\
\text { development }\end{array}$ & & \\
\hline
\end{tabular}

\section{Observations}

Use the observation sheet provided to record what happens in the classrooms that you observe. The sheet can be filled out in draft form. At the end of each day, write out the lesson in full in a narrative form. (This should be done on the same day while the memory of the lesson is still fresh.) Using the Profile, indicate what aspects were observed, and characterise the lessons in terms of the levels of its dimensions.

If possible, video tape a number of the lessons (cameras will be supplied). Permission of the teacher must be obtained if the lesson is to be video taped. Each lesson should be on a separate tape. The tape should be labelled with the date, school, teacher's name and kind of lesson (grade 8 maths.)

\section{Interviews}

An interview schedule is provided for the principal, teachers and learners. The interview is best characterised as being "semi-structured". The questions on the schedules provide the structure. However, at your discretion, some questions may be omitted if you already know the answer, say by observation. Additional questions may be asked, and probing follow up questions are advisable.

Answers to the questions should be recorded in writing during the interview. With the permission of the interviewee, the interview could be tape recorded. 
The principal should be interviewed towards the end of the week, as there may be things that arise during the study that require his clarification.

Each of the grade 8 and 9 science and maths teachers should be interviewed once. This interview should occur after the teacher has been observed, as again there might be follow up questions based on the observation.

Learners should be interviewed in a "focus group" of about five. Ask the teacher to select the five for you, unless by this stage you have an idea of those whom you would like to interview. Try to get a representative group - balance gender, ability, etc. Make sure that you will be able to communicate with them - especially in the case where you cannot use their home language.

At your discretion, other interviews could be conducted as the opportunity arises. For example, you may have the opportunity to interview a school board member.

At the end of the day, write up the interviews in full, using your notes and the tape recorder, if this was used. This should be done while the memory of the interview is still fresh in your mind.

\section{Documents}

The framework calls for the collection of certain documents, such as a mission statement, school improvement plan, and staff development plan. Other useful documents are lesson plans, worksheets, assignments and tests. If possible photo copy any useful documents. If you use the school photocopier, pay for its use, and you will be reimbursed.

\section{The Final Report}

A framework for the final report is provided. If everyone uses this framework, cross case comparisons will be facilitated. Write up the report using the following headings and subheadings:

\section{The Setting}

Implementation of C2005 and Innovation in General

- Classroom interactions

- Science practical work (not applicable to maths classes)

- Science or maths and society

- Assessment

Capacity to Innovate

- Physical Resources

- Teacher factors

- Learner factors

- School ethos/management

Support from Outside Sources

- Provision of physical resources

- Teacher professional development

- Direct support to learners

- Change forces

- Accountability and monitoring 
Conclusions

Under the heading "The Setting", describe the school in general terms, giving first impressions, something of its history, its appearances, how it is regarded by the community and so on.

Under each of the remaining sub-headings, combine the data that you have gleaned from all the sources, observations, interviews and documents, to provide a detailed description of that subheading. For example, under "Classroom interactions", you will have a number of classroom observations (some video-taped), interviews with learners, teachers and the principal, and a number of documents such as lesson plans and worksheets. Synthesize all this information to provide a coherent and composite account of classroom interaction in the school, or at least in the science and maths classrooms. Refer, wherever possible, to evidence that you have collected and will attach to the report.

It is suggested that you work on the report every day while events are still fresh in your mind. Then at the end of the week, compile the first draft of the complete report. Take this draft to the school and ask for the teachers' and principal's comments and input. There may be things that in their minds you have misinterpreted, or there might be new and valuable information that they would like to add at this point.

Once you have received this input, compile the final version of the report. At this point, add a final section called "Conclusions". You may, at this stage include your overall impressions and interpretation of events. Since these are your personal impressions, they need not be shared with persons at the school. It is your opportunity to write down some of the things that you feel might have been inappropriate to share.

In addition, in this concluding section discuss the school as a whole in terms of the levels of each of the profiles.

Finally, attach to the report all the evidence that you have gathered such as copies of documents, descriptions of observations and transcriptions of interviews. All of this will be filed in a two ring binder.

\section{Conclusion}

The relationship between yourself and the people at the school raises some ethical issues. As an observer, you do not wish to influence the outcome of what you observe, but in practice it is impossible to achieve this ideal. People behave differently when observed. The ethical issue is should you allow your presence to be a positive factor for the school, despite the fact that it will skew your observations? Ethically, I (JMR) would answer yes. It seems right that the school should benefit in some way. So if there are ways you can be of help e.g. teach some demonstration lessons or provide some resources, feel free. In order to minimise the impact on your observations, you might provide such assistance towards the end of the week, rather than at the beginning of it. As part of the case study, you might then be able to gauge the effect of your intervention. 
CASE STUDY TEACHER INTERVIEW

Surname and initial of teacher:

Name of school:

Interviewer:

Date:

Note to the interviewer: The interview should be tape recorded, but please make detailed notes in the spaces provided and on the back of the interview schedule. Use the recording if necessary to fill in gaps after the interview is completed.

\section{Profile of implementation}

\section{Classroom interaction}

1 Do you have a set format for your lesson plans? If so may I see a copy?

2 How are learners' ideas accommodated in your lesson?

3 How do you form the groups? Do you change the groups regularly?

4 Do you think meaningful learning occurs during group work sessions? Can you distinguish between the learning that takes place in groups and that that takes place normally?

5 How much time do you give your learners to talk to each other about the lesson, either in English or in their mother tongue?

6 Where do you get your own background knowledge? (interviewer to probe) 
7 For what purpose are questions asked during the lesson? Please give some examples. Probe further ask teacher if uses questions to:

- Engage learners (arouse their interest)

- Explore (what learners already know about the topic)

- Explain (the new topic)

- Expand (what learners already know about the topic)

- Evaluate (what the learners have learned)

8 What do you do, if when trying to establish the prior knowledge of your learners, you discover that there are gross misconceptions in their understanding? Do you think it is possible to use incorrect replies from your students to address misconceptions? If yes, how would you do this?

9 What is the directive in C2005 about the use of textbooks in the classroom?

10 How do you make use of textbooks in the classroom?

11 Other than textbooks, which materials do you make use of in your teaching, e.g. charts, temporary exhibits etc?

12 What, in your view, are the benefits or problems associated with allowing debate and the presentation of alternative views of the content during a lesson?

13 What short or long term investigations are your learners currently carrying out? How will they present their findings? How are you going to assess their work?

Science practical work (ask of science teacher only)

14 In your opinion are demonstrations as effective in getting the message across as the learners carrying out the practical themselves? 
15 Do demonstrations provide enough opportunity, in your opinion, to ask predictive questions and test prior knowledge?

16 Do you sometimes find specimens in your environment to use during your lessons? Give some examples please.

17 Do you think it is possible to allow learners to plan and perform demonstrations? What constraints could hinder this process?

18 What procedures do you feel are important in running a successful practical session? Consider before, during and after the lesson.

19 What do you understand about the term 'guided discovery'?

20 How do you feel about learners being allowed to do their own 'open' investigations? What are the practicalities involved?

21 Do you take time after a practical to consolidate the learning that was meant to take place? If yes, what would the benefits be?

22 Interpretation of data is a very important skill in science. Where do you think learners should learn graphing and tabulation skills? In maths or in science?

\section{Science/maths in society}

23 How easy or difficult is it to find examples and applications from everyday life to illustrate scientific concepts or mathematics procedures? Please provide some examples. 
24 Are learners generally able to see applications of science/maths in everyday life? Do they ask questions about science/maths in the context of everyday life?

25 Is it possible, at least some of the time, to base a lesson within the context of a specific problem or issue faced by the community? Give an example of what you have done in your own classroom.

26 How practical is it to get the learners actively involved in investigations into the applications of maths, science or technology in their own environments? Explain.

\section{Assessment}

27 What percentage of questions in a test should be recall type as opposed to comprehension, application and analysis, given the background of your learners? Do your tests reflect this? May I see a test you have given to learners at the end of this interview?

28 What is your opinion on including questions based on the learners practical work in written tests?

29 How quickly are you able to mark and return written tests to your learners given the average workload on a teacher?

30 Mention what forms of assessment other than written tests you use when assessing your learners work?

31 Should learners have some say in how assessment of their work should take place? 


\section{Profile of capacity to support innovation:}

\section{Physical resources}

32 Compared to other schools in your area, how would you describe your physical working environment? Refer to buildings, toilet facilities, textbooks, electricity, furniture, science apparatus, copying facilities, resources and security.

\section{Teacher factors}

33 What are your teaching qualifications?

34 How long have you been teaching?

35 How long have you been teaching science/maths?

36 Do you intend studying, or are you currently studying, further? If so, what is it that you are or will be studying?

37 How are you able to keep up with current trends in education e.g. OBE methods?

38 In your opinion, how effective has the INSET (in-service training) been that you have been provided with?

39 Do you believe that the basic teaching qualification is adequate to serve a teachers lifetime in the career? Should it be renewable, say, every 5 years? 
40 How many times (days) have you not been able to come to school this year so far owing to reasons beyond your control?

\section{Learner factors}

41 What is the average proficiency in English of your learners?

42 Is there a problem with absenteeism amongst your learners? If yes, to what do you ascribe this?

43 Are most of your learners adequately nourished? Does the school have a feeding scheme that learners may benefit from?

44 Do some of your learners have domestic duties that may hinder their ability to do homework?

45 Do your learners generally come from a home environment where they are encouraged to do well at school?

46 Do many of your learners have a place where they can work after school in quietly and not disturbed on their own?

47 Would at least some of your learners do their school and homework if they were not forced to do so?

\section{School ecology and management}

48 Is the timetable strictly adhered to in the school? 
49 Is the headmaster always present and approachable during school hours?

50 How often are staff meetings held?

51 What disciplinary procedures are in place for teachers who show misconduct, e.g. late arrival, absenteeism etc?

52 When are extra-mural activities scheduled for?

53 Are learners sometimes called out of class to attend practices for concerts or sports matches?

54 Do teachers and learners have a forum within the school where they may influence management on certain issues?

55 Describe the functioning of the schools Governing Body and the School Management Team?

56 If learners are seen walking around the school during class time, what could be the reason? 
57. If you are an HOD please answer the following questions:

As an HOD do you contribute to any of the following management activities? In your response to each please provide your opinion on the main challenges your school is experiencing with regard to them.

\begin{tabular}{|c|c|}
\hline \multicolumn{2}{|l|}{ A. Curriculum development } \\
\hline \multicolumn{2}{|l|}{ B. Curriculum implementation } \\
\hline \multicolumn{2}{|l|}{ C. Financial management } \\
\hline \multicolumn{2}{|l|}{ D. Learner support material (LSM) selection } \\
\hline \multicolumn{2}{|l|}{ E. LSM provisioning } \\
\hline \multicolumn{2}{|l|}{ F. Learning programme development } \\
\hline \multicolumn{2}{|l|}{ G. Assessment } \\
\hline \multicolumn{2}{|l|}{ H. Monitoring and evaluation of classroom practice } \\
\hline \multicolumn{2}{|l|}{ I. Classroom management } \\
\hline \multicolumn{2}{|l|}{ J. Time-tabling } \\
\hline \multicolumn{2}{|l|}{ K. Year planning } \\
\hline \multicolumn{2}{|l|}{ L. Policy issues } \\
\hline \multicolumn{2}{|l|}{ M. School development plan } \\
\hline N. Managing and development appraisal system & \\
\hline
\end{tabular}




\section{Physical resources}

58 Has your school received any form of physical assistance (books, apparatus, building) from the department or any other source during 2002? Give details

59 List the learner support materials that were supplied to you by your Department, NGO or produced by yourself or your team.

60 How adequate have these supplies been?

61 What physical resources do you currently lack in order to make your teaching and the learners learning more effective?

\section{Professional development}

62 Does the school have a Staff Development plan? Please explain. (Note: Ask for a copy of the plans.)

63 What kind of INSET is available for your teachers? Who provides it? How is it organized? How effective, in your opinion, are the INSET providers, including teachers when they take on this role?

64 Does school based INSET, including subject meetings, occur? Give examples.

65 How effective, in your opinion, is the professional development of teachers at your school? Does it empower them? Does it make improvements in the classroom? Give examples. 
66 How long do the courses last that you have been sent on for the implementation of C2005?

67 How was information gained from the workshops shared with other teachers?

\section{Support to learners}

68 Are extra lessons provided for learners who need them?

69 What enrichment activities are provided for the learners e.g. excursions to museums etc?

70 Does your school offer bursaries or scholarships for learners?

\section{Monitoring mechanisms and accountability}

71 How well would you say that C2005 is being implemented in your school? Give examples.

72 If C2005 were to be made voluntary, would you still implement it? Why or why not?

73 Is the progress or improvement in the school as a whole monitored, and if so how and by whom? Explain. Do you use the quality assurance checklist? If so, how often?

74 How often does the CI, District Manager or other people who conducted INSET visit your school? What do those persons do in the school during such visits?

75 How do you feel about these visits? 
76 Do you think the department should return to the system of having school inspections? Explain.

77 Does your HOD and Principal offer adequate support for your teaching?

78 Who does the monitoring and evaluation of the work that you do and ensure that it up to standard and how often is this done?

\section{Comments}

Thank you for this interview. We appreciate your help very much. 
CASE STUDY PRINCIPAL INTERVIEW

Surname and initial of principal:

Name of school:

Interviewer:

Date:

Note to the interviewer: The interview should be tape recorded, but please make detailed notes in the spaces provided and on the back of the interview schedule. Use the recording if necessary to fill in gaps after the interview is completed.

Capacity to support innovation

\section{Learner factors}

1. Do you believe learners at your school are generally well behaved? Why do you say this?

2. Do you believe learners at your school are generally motivated and hard working? Why do you say this?

3. What is learner attendance like at your school? Do learners remain in class for the whole school day?

4. Are there factors that inhibit the ability of learners to learn, such as language proficiency, lack of support at home, lack of text books, etc? Please describe the major factors.

\section{Teacher factors}

5. How would you describe teacher morale at your school? Why do you say this?

6. Do you believe there is a spirit of collaboration amongst teachers at your school? Do they plan lessons and grow professionally together? 
7. How dedicated are your teachers? Why do you say this?

8. Are there teachers who do not come to school at the end of the month?

\section{School ecology and management}

9. Does the school have a time-table? Is it strictly adhered to? (Note: Look at the time-table and try to determine if it is functional.)

10. Does your school have problems with vandalism, theft, violence and lack of security. Please give examples.

11. Does the school have a discipline policy or code of conduct? If so is it generally known and adhered to? Does it make a difference? Give examples.

12. Does the school have a mission statement? If so, how was it developed, and how has it influenced the functioning of the school? Give examples. (Note: Ask for a copy of the mission statement.)

13. Does the school have a School Development plan? Please explain. (Note: Ask for a copy of the plans.)

14. Does the school have a SGB? If so, does it meet regularly? Are there minutes of these meetings? (Note: Ask for a copy of the minutes.) Does it provide effective leadership. Give examples.

15. How supportive are the parents of the school and the community in general? Give examples. 
16. Describe how you believe decision-making is handled at the school. Which stakeholders, e.g. SMT, SGB, etc. are involved in decision-making? In what way are they involved? How effective is their involvement? Explain.

17. Are funds available for the purchase of classroom resources, such as books and laboratory materials? If so, what is the procedure for the use of these funds?

18. Is your school operating under the section 21 company act? If so, how does this arrangement work?

19. Can you describe a situation where the whole school has mobilized for a special effort (e.g. fund-raising or the improvement of the facilities)

Outside Support

Physical resources

20. Has your school received any form of physical assistance (books, apparatus, building) from the department or any other source during 2002? Give details

21. List the learner support materials that were supplied to you by your Department, NGO or produced by yourself or your team.

22. How adequate have these supplies been?

23. What physical resources do you currently lack in order to make your teaching and the learners learning more effective? 


\section{Professional development}

24. Does the school have a Staff Development plan? Please explain. (Note: Ask for a copy of the plans.)

25. What kind of INSET is available for your teachers? Who provides it? How is it organized? Is it effective? Give examples.

26. Does school based INSET, including subject meetings, occur? Give examples.

27. How effective, in your opinion, is the professional development of teachers at your school? Does it empower them? Does it make improvements in the classroom? Give examples.

28. How long do the courses last that you have been sent on for the implementation of C2005?

29. How effective, in your opinion, are the INSET providers, including teachers when they take on this role?

30. How was information gained from the workshops shared with other teachers?

\section{Support to learners}

31. Are extra lessons provided for learners who need them?

32. What enrichment activities are provided for the learners e.g. field trips, trips to museums etc. 
33. Does your school offer bursaries or scholarships for learners?

Monitoring mechanisms and accountability

34. How well would you say that C2005 is being implemented in your school? Give examples.

35. If C2005 were to be made voluntary, would you still implement it? Why or why not?

36. Is the progress or improvement in the school as a whole monitored, and if so how and by whom? Explain. Do you use the quality assurance checklist? If so, how often?

37. How often does the CI, District Manager or other people who conducted INSET come to the school?

38. How do you feel about these visits?

39. Do you think the department should return to the system of having school inspections? Explain.

40. Who does the quality assurance of the work that you do and how often is it done? 


\section{Comments}

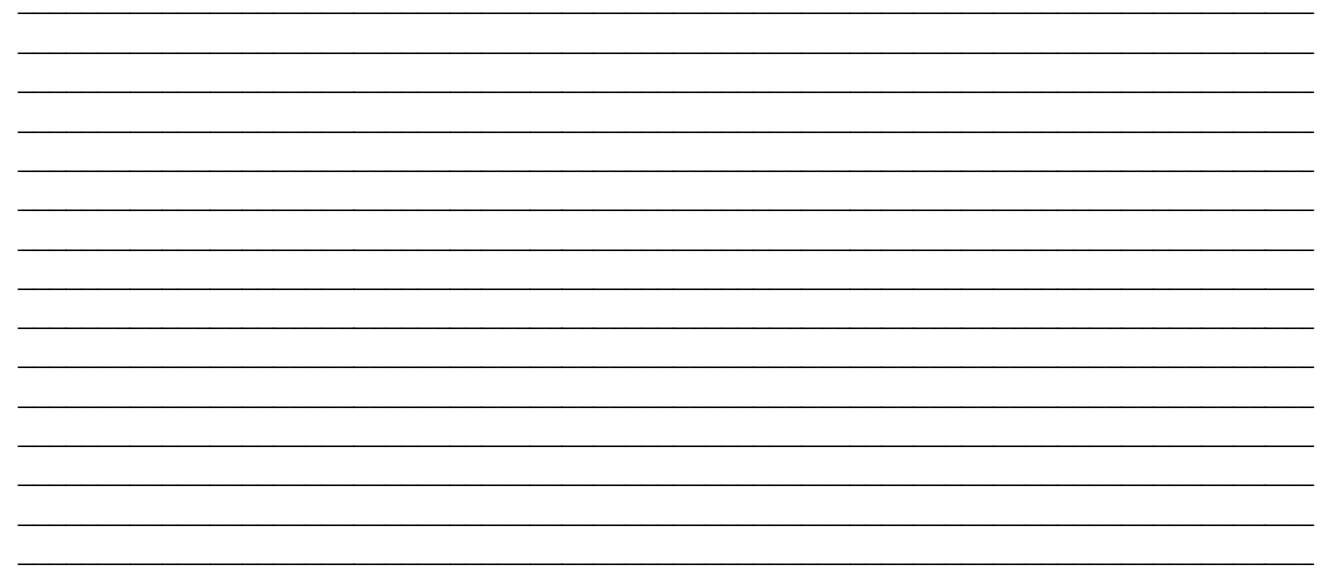

Thank you for this interview. We appreciate your help very much. 
Surname and initial of learner(s):

Name of school:

Interviewer:

Date:

Note to the interviewer: The interview should be tape recorded, but please make detailed notes in the spaces provided and on the back of the interview schedule. Use the recording if necessary to fill in gaps after the interview is completed.

(Note: Check the following questions (1-41) with your observation results)

\section{Profile of implementation}

\section{Classroom interaction}

1. Do you answer questions your teacher asks in class? Do you think that is important for your teacher to ask question? Why?

2. When do you get bored ( don't listen to the teacher, dreaming, chatting etc.) in the class?

3. When do you find the lesson interesting ( listening, answering question, making notes etc.)?

4. Are there other sources (than the text book) of written information that you use in class? If yes: can you give some examples?

5. Do you make your own notes during the lesson? If yes: can you show them to me?

6. Do you sometimes work in groups? If yes: what do you do? 
7. When is the last time that you offered, on own initiative, a contribution to the lesson? What was that contribution?

8. What do you do when you find your work in class too difficult? Do you understand the work your teacher gives you? If not: what do you do when that happens?

9. Do you use a homework book? If yes: can you show me what you have written in there this week?

10. Do you think you get too much work? If yes: what do you do when you get too much work? Can you cope with it?

\section{Science Practical (Ask only of the science group)}

11. Does your teacher use demonstrations in class to make the lesson clear? If yes: when was the last time your teacher used demonstrations in class?

12. Do you sometimes assist in planning and doing demonstrations in your class? If yes: describe some of these demonstrations and how you assisted.

13. Do you do a lot of practical work? If yes: describe some of the practical work you have done in the last month.

14. Do you understand graphs and tables and can you use them in your work? In which grade and subject did you learn to work with tables and graphs? When is the last time you worked with tables and graphs in class? 
15. Do you sometimes plan and carry out your own survey or investigation? If yes: can you give some examples of such a survey or investigation?

16. Have you ever written a scientific report in which you had to justify your conclusions? If yes: do you speak about your survey or investigation in class?

\section{Science/Maths in Society}

17. Do you speak in class about science applications in everyday life? If yes: can you give an example?

18. Have you ever undertaken a project in your local community to tackle a specific problem or a specific need? If yes: can you give an example of such a problem?

\section{Assessment}

19. Do you write a lot of tests? If yes: when was your last test? What was it about?

20. Do you have to learn off by heart for tests?

21. Do you think all the questions in the test are of the recall (or memory) type or are there sometimes more 'thinking questions'? If yes: can you give an example?

22. How long does it take to get a test back after you have written it?

23. Are some of the questions in the test based on practical work that you or your group did? (Science only) 
24. Do you also get marks for: reports on activities, creation of charts or reports on extra reading assignments?

25. Do you sometimes a present your survey or investigation to the class? If yes: when was the last time you did that?

26. Do you keep your best work to show it to other people?

Capacity to support innovation

\section{Learner factors}

27. How many days have other learners been absent from school so far this year? Why do you think they are absent from school?

28. Do you have lot responsibilities and work to do at home? If yes: can you mention some of these responsibilities?

29. Do you have enough time to do your homework? How much time do you spend on homework per day?

30. Where do you study? Is that place a good place for your study?

31. Do your parents/guardians help you with your homework?

32. Do you have your own textbook and school material (such as: pencils, paper, bag etc.) at home? 
33. Do you tell your parents/guardians about the marks you get?

34. Do you like school?

35. Do you often help other children with their learning?

Outside support

\section{Support to learners}

36. Where do you get school lunch? Do you have enough food everyday?

37. Do you get extra lessons? If yes: mention the name(s) of these extra lessons?

38. Do you sometimes go out on field trips with your class? If yes: when was the last time and what did you do?

\section{General}

\section{School environment}

39. Is there a Student Representative Council in your school? If yes: did you ever go to this SRC with an issue? If yes: did this visit help you to solve, for example, your (study) problem(s)?

40. Do you feel comfortable when you are in school? If not: what is the problem? 
41. Is your school a safe place for you? If not: why do you think it is not safe for you in your school?

Comments

Thank you for this interview. We appreciate your help very much. 
APPENDIX 6 


\section{School B}

\section{J.M.Rogan and E. Kafanabo}

\section{The Setting}

SchoolB is situated in a rural circuit of Mpumalanga Province, in an area that was designated as a homeland under the previous government. As a result, it is situated in a fairly densely populated area, consisting of a number of smallish villages with open "farm" land in between. Some small-scale farming is in evidence. Livestock may be seen grazing in the area (including the school grounds), while some houses are surrounded by mielie fields and vegetable gardens. There are a number of services in the area, mostly small shops that sell food, and other personal service providers such as small-time mechanics and hair-dressing establishments. However, many of the people in the area have found employment in the nearest city, some $120 \mathrm{~km}$ distant. Hence many, including the parents of some of the children in the school, live in the city and return to the area only on weekends or at the end of the month.

SchoolB has 392 grade 7 to 9 learners and 15 staff. There are three grade 9 classes, and four for each of grade 7 and 8 . The school itself is typical of many of the schools in the area having been built some 18 years ago. It consists of three rows of classrooms, one for each of the three grade levels. The third wing, home of the grade 7 classes is somewhat newer than the other two. The principal's office, staff room and HOD office is found at right angles to the two older rows. The school has recently been renovated by the Department of Education. All the buildings have been painted and the floors tiled. The ceilings have been repaired, and electricity restored to all rooms. (Previously most fittings had been stolen.) A water tank has been erected which is filled by means of an electric motor. Water is available in two outdoors taps. A security fence has been erected all around the school property, and lights come on automatically at night. The School Governing Board (SGB) paid for burglar bars to be installed in all windows and doors. Finally toilets for the teachers (but not learners) have been erected.

The school has a number of large trees that provide shade. Part of the courtyard is covered with lawn that seems to have lost the battle to survive in the sandy conditions that prevail throughout the grounds. The strip of ground along the edge of the three buildings making up the courtyard have been marked off as "garden" using pipes from broken desks. However, other than a few succulents, nothing grows in these "gardens". The remainder of the courtyard consists of sandy soil with no vegetation. The outer boundaries of the school grounds are used to store broken furniture and the remains of the building materials used in the recent renovations. The grounds are exceptionally clean and free of litter.

The classrooms contain mainly tables and chairs for the learners. In all classrooms, the tables are pushed together to accommodate group-work. The eighth grade row consists of room separated by roll-down metal dividers. This arrangement makes it possible to convert the rooms into one long "hall". However, even with the dividers down, noise in one room carries easily to the next. The end room in this row is in the process of being converted into a library. So far all that the room has is an improvised shelf, two tables and textbooks - new and old. The end room of the $9^{\text {th }}$ grade row is being converted into a science "laboratory". However, at this stage all it houses are a set of improvised shelves and some boxes of micro-chemistry kits and chemicals, all unopened. The HOD for science and mathematics has made this room into her "office", and so it also houses her table and cupboard. Other than the chairs, tables and a blackboard, classrooms are completely bare and uninspiring. One exception is the grade 7 rooms, where some recent learner work is displayed on the walls.

\section{Implementation of C2005 and Innovation in General}

Work covered in four classes over a period of one week was observed in detail. The following content was covered during this time period:

Grade 8 maths - the addition, subtraction, multiplication and division of fractions, leading to the BODMAS rule. 
Grade 8 science - static electricity and lightning.

Grade 9 maths - the addition, subtraction, multiplication and division of fractions. Class work consisted of a combination of individual work, group work, and whole class teaching which included individuals solving problems on the board.

Grade 9 science - human growth and development, including the measurement of height, averages and graphing.

\section{Classroom interactions}

Teachers report that they have become more comfortable with the implementation of C2005. At first it was something of a struggle. However, after a year or so, they are much more comfortable with OBE. There is a general feeling that C2005 is being well implemented in the school. Many changes have been brought about in both teaching and learning styles. As one teacher put it, "We are in favour of the vision of teachers owning the lessons, and the learners being responsible for their own learning. That is what I like. It has relevance." It was generally agreed that there is no going back to the old ways.

Classroom practice has certainly changed. One obvious difference is that on entering any classroom, one sees that tables and chairs are arranged in groups and not rows facing the teacher. The arrangement of furniture is not simply a cosmetic change. Significant changes in teaching practices have also occurred. For example:

In both maths classes, learners were encouraged to work through the given problems in groups, and in so doing help one another. In some cases, learners worked in pairs and then shared and compared their answers with others in the group.

In grade 8 science, a noticeable pattern is followed. A passage (at times containing an activity) is given to the groups. They read the passage and do the activity e.g. rubbing a comb with a cloth. They then answer a set of questions prepared by the teacher. Groups then report back on their answers and the final answers are written on the board.

Grade 9 science followed a somewhat similar pattern. However, answers to the questions were sought more by discussion that by reading a passage. The grade 9 science class also spent more time on measurement, finding the average and graphing.

In previous years, one might have expected to find the teacher lecturing, reading out of a textbook, questioning pupils and/or writing notes on the black board. The pupils' role would essentially have been to answer the questions and to copy notes from the board into their books. Hence, as can been seen, significant changes in teaching styles have occurred in a relatively short space of time. Such a change is no mean achievement. Nevertheless, these new teaching styles are being used, for the most part, to achieve the same goals as before. The vessels may have changed, but it is the same wine. There is very little evidence that the specific outcomes of either mathematics or science are being addressed. The understanding of OBE implementation is seen as the changes in teaching styles described, and not the achieving of the specific and critical outcomes.

In mathematics, the thrust of the lessons was on the skill of operations on fractions. The goals of the lessons were essentially what they would have been before the introduction of OBE, although different teaching methods are being used to achieve theses goals. In most cases, rules (algorithms) were taught and used by the learners to solve the given "problems". Although some new OBE textbooks are available, these are not used to frame either the curriculum as a whole or the individual lessons. To sum up, new teaching methods were used to cover the old content. In the process, no specific outcomes were addressed, except perhaps SO1.

Maths teachers used group activities to engage learners to do activities in group work, but most of the time the fast learners where the ones busy doing the activities. Other learners did not engage themselves in a meaningful learning. Teachers did not provide any notes for the learners, but gave them mathematical problems to look for solutions in class and as home-work. 
Maths teachers tried to ask questions to probe the learners on their prior knowledge. But most of the time the background knowledge was not openly expressed by the learners. The learners kept quiet most of the time. The questions where not based on the problem solving techniques. In learning mathematics the learners did not take full responsibility for their own learning. They were always working by being pushed by their teachers. For example, most of their home-work was not done on time (at home); instead they did their home work in class the next morning, when the teacher was asking for the exercise books to be marked. In such cases these learners do not have questions to ask relating to problems in their local community since they did not do their homework in time.

The relation of mathematics to everyday has not been smooth sailing. "It is easier to find examples of the application of maths in everyday life for some topics but not for others. For example, it is not easy to find applications of the multiplication and division of fractions in everyday life. On the other hand, it is easy to find examples in geometry and statistics. Learners are sometimes able to make connections to everyday life. For example, when I was teaching angles, they could see that they are very important in building. However, they do not often ask questions that relate everyday life to maths.

"It might be possible to base maths lessons on problems related to everyday life. For example, if we were to take rubbish disposal as a topic, we would be able to do statistics on the types of rubbish that accumulate. However, I have not tried doing anything like this yet. Learners are not yet used to undertaking this type of investigation. As they get used to OBE, it might be possible to do something like this. They will get used to OBE in time and do investigations on their own. Teachers are not yet ready for this kind of activity either - we have not seen it in action. MSSI has helped us become prepared - other teachers (non-MSSI) have not had similar help."

The situation in science is a little more complex. In grade 8 , lessons were taught using photocopied pages from a new OBE text-book. Learners read some information and then did an activity (rubbing a comb with a cloth) from the handout. Finally they answered a set of questions prepared by the teacher. These were written on a piece of cardboard and displayed on the board. Each group wrote down its answers - a scribe had been selected. When this part of the lesson was completed, groups were asked in turn to provide answers to the questions; these were discussed and the "final" answer written on the black board by the teacher. The next lesson proceeded in much the same way, except the activity was done by means of a demonstration - two balloons repelling one another. Since the handout in this lesson included a passage on the formation of lightning, there was more information to be acquired by the learners. This knowledge was gained by reading the passage and then answering the teacher's questions. As in the maths classes, the only specific outcome really addressed was SO2. However, it could be argued that observing static electric phenomena is a very elementary level of $\mathrm{SO} 1$.

The grade 9 science classes were dealing with human development. The aspect of human development that occupied most of the week was the measurement, averaging and plotting of the heights of the learners in class. Some time was also devoted to the bodily changes experienced by learners since the age of six. Perhaps more than the other lessons observed, these had the potential to address some of the specific outcomes - but for the most part the potential was not realised. Learners were not taught the skills that they needed to make sense of the task, and so they struggled on without producing the kind of work that would be expected of them in an OBE class. Some of the problems that were encountered were lack of measurement skills, confusion about units of measurement (both inches and centimetres were used) and trying to plot their results on a graph provided which had an inconsistent scale on one of the axes, and inappropriate scales on both.

One curious and unexplained aspect of the grade 9 science classes was that the boys' heights were averaged and plotted, but not the girls. 
Nevertheless, the grade 9 science classes are heading in the right direction, and if the teacher is given support and guidance, the type of learning envisaged by C2005 could develop over time. Some interesting projects are planned for the future. The intentions are there. The grade 9 teacher had the following to say:

"I have not done any long-term investigations with my learners this year, but am intending to do one on reproduction. Last year there was one on digestion. Groups gathered information from texts, the high school and the clinic. They then presented their findings in the form of an oral presentation and a written report. They were assessed on what they understood."

“Open investigations could be an effective method, but I do not practice it myself. I am still planning to do it. It can be effective if they use their own ideas. It encourages them to think deeply and critically."

"It is possible to base a lesson on a specific issue or problem faced by a community. I have not done it, but it is something that I plan to do. There is a community nearby that does not have access to water. The water that they get is salty. I want my learners to try and find out why this is the case. They will analyse the soil."

\section{Science Practical Work}

In the science classes in grade 8 and 9, the teachers tried to use classroom demonstrations to help the learners develop concepts. Attempts are being made to make science more hands-on, making use of every-day equipment such as measuring tapes, combs, balloons and electric plugs. The science teacher in grade 9 managed to use tape measures, rulers and graph paper to illustrate the concept of height and growth to students. After the experiment the learners tried to draw and explain their data using graph paper provided. Learners participated enthusiastically to all activities given that is "hands on", but did not assist in planning the activities.

In both classes grade 8 and 9 learners performed guided discovery type practical activities and group work was done. Students where given photocopied sheets from a book, which showed them how to perform the activities and had questions to answer.

Nevertheless, more could be done. The school has sets of micro-science kits and chemicals, which have not yet been used.

\section{Science/maths and Society}

As noted previously, while new teaching styles have been adopted, the actual content of lessons is mostly unchanged. Science lessons mostly focus on SO2, with some development of SO1. Maths lessons mostly focus on SO1. The SOs that deal with the interface of maths/science and society are largely absent from the lessons. Nevertheless, the grade 9 science teacher feels that making the link to everyday life is relatively easy in science.

"It is not difficult to find applications of science in everyday life. What we are doing is practical. I use examples that the learners are exposed to every day. The learners are able to understand these applications, for example in introducing electricity, which they are familiar with. When explaining that unlike charges attract, I used the analogy of male and female. However, learners do not often come up with questions on their own. Some do, for example questions about plants."

\section{Assessment}

The science/maths subject policy calls for two tests per quarter. It does not specifiy any other kind of assessment. 
Written tests were used as one of the methods to assess the students. For example the grade 9 maths classes were given a written test to cover subtopics on angles and fractions, which the students have been doing for the past two to three weeks. Most questions did not require recall, but needed application of knowledge gained in the study. Some questions needed higher order thinking. Grade 9 teachers usually marked and returned the tests promptly. The grade 8 maths teacher takes a week to complete marking the tests.

Despite the lack of mention of other assessment strategies in the policy document, all the teachers used other sources besides the tests to assess the progress of their learners. These include projects (e.g. the creation of a chart), class-work, homework, written reports and oral presentations. The latter two are based on longer term projects such as the investigation of the digestive system or African monitory systems.

No learner portfolios where seen in science and mathematics.

\section{Summary}

It is clear that some significant changes in teaching and learning have taken place at the school some positive and some less so. On the positive side, the learners are certainly less passive than in the past. Group work (not just sitting in groups) is a common practice. Learners help one another, especially in maths, and discuss answers to questions about the topic in science. Both teachers and learners seem comfortable with this practice and, more importantly, feel that it leads to effective learning. (Interviews) Teaching no longer consists of the teacher writing notes on the board and the learners copying it into their books. Meaning is made of a topic and learners construct their own notes based largely on answers to questions that they have worked on in groups.

Three major problems seem to have developed in the implementation of C2005 at the school. Since the first two are inter-related, they will be dealt with together. They are time and "meat". In one of the observed sequences, the grade 9 science class considered questions about how their bodies had changed over the years. The questions were first answered in groups, and then each group reported back to the whole class. All in all the process took about 90 minutes. Since at the beginning of the lesson, most learners would have already known the answers to these questions (e.g. girls begin to grow breasts), what had been achieved by the end of 90 minutes? Was it really worth spending so much time on something so trivial and lacking "meat". The implementation of C2005 does call for spending more time on fewer topics, and covering these topics in greater depth, but what is done in this time must be "meaty" and not trivial. Time management and planning does appear to be an endemic problem that likely existed before OBE. Gauging by the pace of coverage observed during the week, it is likely that the learners might "finish" about half of any textbook, new or old. Essentially then, in one calendar year, about half the work is done, compared to schools that cover most of what is in the text book that they are following - or in C2005 terms meet the expected levels of addressing the outcomes. If this trend is repeated year after year, then by the end of grade nine, the learners will in essence be at about grade 5 level.

The third problem revolves around what appears to be a serious misconception of C2005. The perception is that implementing OBE means learners working in groups and pooling their knowledge about a particular topic such as human growth. The teacher must not teach but facilitate. While there is obvious merit in this position - and it has certainly been pushed strongly at workshops - it loses sight of the essence of OBE, which is that there are critical and specific outcomes to be achieved. There is no one way of achieving these outcomes - group work being one, but direct teaching (telling) being another. For example, there are processes of science that form part of SO1, one of which is communicating data by means of tables, graphs, diagrams and so on. Such skills have to be taught - they will not emerge from a group discussion. They then need to be applied - something that C2005 is very specific about. They are not taught just to pass an examination, but to be applied in real life situations. The same reasoning applies to new knowledge. Concepts which are not generally known, such as kinetic energy or logarithms, will 
not emerge from a group discussion - they have to be taught. The curriculum needs to be framed by achieving the outcomes in the most effective and efficient way, rather than by adopting a particular model of teaching.

\section{School Ethos and Management}

\section{Capacity to Innovate}

The immediate first impression that a visitor gains of the school is that it is run according to wellestablished and observed routines. The school begins with an assembly at 7:45, which is held in the school courtyard. Learners line up according to their classes. Late- comers are assembled in a separate area, and their names are recorded. Prayer, hymns and scripture form part of the proceedings each morning. Other topics range from being good citizens, coming to school on time, keeping the school clean and reports on the choir competition. Most teachers arrive in time for the assembly, although transport problems sometimes prevent their attendance. Teachers are required to sign-in and sign- out each day in a logbook kept in the principal's office.

There are other indications of a well-run school. The timetable is based on an 8-day cycle, and is strictly adhered to. Teachers and learners know where they should be at any given time. Each classroom has the version of the timetable that pertains to that particular class.

The school has a policy document which includes a vision, mission statement, departmental goals and policies on issues such as admission, school fees, the curriculum, care of the school grounds, and so on. (It is attached.) It was approved on 31 May 1999, following a process that saw input from all stakeholders. Parents were consulted, followed by the teachers and learners. The School Management Team then wrote a draft document, which was then circulated to all stakeholders for their input.

The school has a discipline policy, which was drawn up in conjunction with the learners' representative council. It also has a procedure for dealing with teachers who might be guilty of misconduct.

The school has an active School Governing Body, which, according to the principal, has proved to be of great help in the running of the school. They meet quarterly, but more often than that if the need arises. Minutes of the meetings are kept, and are available. (See attachment.) They help with fund raising. For example, they provided the money to install burglar bars on all doors and windows at the school. The parents of the school are very supportive and have been helpful in all kinds of ways. They have helped raise funds, and have designed forms to help with fund raising. If any problems arise, they are consulted and solutions are found.

Staff meetings are held on an "as needed" basis. At times it has been as often as three times a week. Hence there is a viable mechanism for communication between the professional staff of the school.

The principal is visibly present at the school most of the time. In fact he teaches science to all four $8^{\text {th }}$ grade classes. He is thus in a position to take care of problems as they arise, such as dealing with a fight or taking a sick child home.

In summary, the ethos of the school, and the way in which it is managed, is supportive of the kinds of innovations envisaged by C2005. What exists at present could provide a solid platform on which to continue to build and improve.

\section{Teacher Factors}

The teachers are all qualified to teach maths and science, being in possession of STDs or UDEs. One is studying for a degree at the moment, and others intend to study further at some future date. A strong desire to learn, both academically and professionally, was expressed on a number 
of occasions. Hence the notion of being a life long learner is part of the teachers' way of thinking and acting. In this respect, they are fine role models for the learners. However, one worrying aspect is that for the most part, these study plans are not in the areas in which the teachers teach but in areas such as "communication" and "human growth".

Teacher morale at the school is good. However, the threat of redeployment is discouraging. Teachers co-operate well with one another and are hard-working. There is a good team spirit amongst teachers at the school. When one of them attends a workshop, they plough back what they have learned by passing on the knowledge to other teachers. This collaboration occurs in all the learning areas.

All teachers expressed satisfaction with the INSET received from the department and through the MSSI project. They claimed to have found it very useful, and wished that could receive more of it. School based INSET is in place, in theory, but does not seem to have really gotten off the ground.

As a rule, they are motivated and dedicated in their teaching. They try to do their work by applying different teaching methods, use improvised resources in teaching, and provide extra classes to their learners. Conversations with them, both formal and informal, are often peppered with phrases that convey their concern and care for the learners at the school. Interactions between teachers and learners are relaxed and respectful. The teachers' dedication extends to teaching for a full day, every day. There is not sitting in the staff room reading the paper instead of being in class at this school!

Attitudes towards the implementation of C2005 are somewhat mixed. They have all struggled with coming to grips on how to implement it. However, for the most part they are solidly in favour of it, and would continue to implement it, even if it were made voluntary. They see it as being very beneficial to learning. A minority position is that C2005 is "too weak" and was implemented before the CIs really understood it themselves. If given a choice, it would be phased in more slowly.

In summary, the capacity to innovate, in terms of teacher capacity is good. The teachers are qualified, motivated and dedicated.

\section{Learner Factors}

In general the learners are well behaved, under control, hard working and motivated. There are a few problem cases. However, when they are punished they respond. They are punished by giving them manual work to do like sweeping and scrubbing the floor, because corporal punishment is forbidden by law.

Language proficiency among the learners is poor to reasonable. It is not possible to teach in English alone. The language of instruction at the school is both English and Tswana. Both languages are used by the learners for speaking and writing.

Learners attend school on a regular basis and absenteeism is not a major problem. The average attendance probably runs at about $90 \%$. Most absenteeism can be attributed to the older boys, who like to stay away from school in order to associate with peers outside the school. These are mostly repeaters, who should be in high school, and are ridiculed by their peers. Some stay away to indulge in alcohol drinking, and others because they are not encouraged by their parents/guardians to attend school. Most learners do not live with their parents.

Some learners have domestic duties that would prevent them from doing homework. At home they have chores such as fetching water, cooking, washing nappies and so on. Most of the learners do not have any domestic problems, but they come from an environment where learners are not encouraged to learn. This is because most of them live on their own. This is a result of having both 
of the parents working far from their homes. They come back during weekends or sometimes once a month to visit the children. These learners come from a community home, where there are no reading rooms for them. They do most of their reading in the living room or their bedrooms. This area does not have a community library. Generally, most students are not eager to learn, and if given home-work, they are forced to do it but not from their own initiative. Some will do their homework without being forced to do so - maybe about $30 \%$. Learners are allowed to stay and do homework at school until 15:00. A few take advantage of this arrangement - maybe $10 \%$.

Teachers seem convinced that they are working with a large number of learners who are not motivated or serious about education. When asked about factors that make it difficult to implement C2005, the attitude of learners often seems to top the list.

Most of the learners do not get enough food at home, and the school does not have a feeding scheme.

The school is a safe place for the learners - they are not bullied. If there is any occurrence of bullying, then the learner responsible is punished. There has never been a case of some one bringing a gun to the school - it is strictly prohibited.

Most learners cannot afford to buy textbooks, but acquire past papers from their friends, elder sisters and brothers. Some make photocopies of books (some areas of interest) which they think is important for their learning.

In summary, the learners present both opportunities and challenges. The learners, in the classroom situation at any rate, are present and obedient. They do what is asked of them without any fuss and are respectful of the teachers and one another. They seem keen to learn. However, language is a barrier, especially as by the senior phase they are expected to learn in English. Lack of general background skills seems to compound the problem. The pace of teaching/learning in general means that after nine years of schooling, these learners are likely operating at about a grade 5 level.

\section{Physical resources}

The school has good buildings, which have been newly renovated. There are enough classrooms for all the grades, as well as extra rooms for a library and a laboratory. There is a staff room, principal's office and a secretary's office. All the rooms have suitable furniture, at least enough for all and in reasonable condition. However, the school does lack cupboards and shelves for teachers to put their books. The library had no books. The laboratory did not have any benches, tables, and has few chemicals and no apparatus besides mirco-chemistry kits. Outside the buildings there is a water tank with a pump, with two taps outside. Textbooks are available, but not enough for all learners to get one. The textbooks are only used occasionally, or not used at all.

The school is protected from vandalism and theft by having a barbed-wire fence around it and burglar-proof doors. So the issue of vandalism is minimised. The school has pit latrines, which were clean, and the grounds were well swept. A small photocopier is present to allow photocopying materials for learners, though in a restricted manner. Only about 40 copies can be made per grade; that is all 4 classes have to share the 40 copies.

In short, the school is probably no better or worse off that most of the other schools in the circuit. While it does lack computers and a properly equipped library and laboratory, it does have resources that might be lacking at some schools such as security and electricity. The resources it does have are adequate for some level of implementation of C2005. 


\section{Support from Outside Sources}

Provision of physical resources

As noted previously, the Department has been active in the past year in terms of the provision of physical resources. The school has been provided with barbed-wire fencing, water and electricity by the department. Not only that, but new rooms have been built and this is also a support from the department. New textbooks have been received, but only for grade 9 and not for all learning areas. These books are insufficient for every student. The school is in need of science kits, chemicals, apparatuses and furniture for the laboratory and the library. Other materials, like stationary, are also needed.

The "investment" of the Department in the school has, for the most part, paid off. The renovated facilities are well looked after and used for learning. Hence, there is every reason to believe that continued investment will continue to pay off. The area where the investment has seen the lowest dividends is in the supply of micro-chemistry kits and text books. It should be pointed out that the micro-chemistry kits come with grade 10-12 support materials, and that these grades are not present in this school. The reason for the under-utilization of textbooks is less apparent.

\section{Teacher professional development}

Workshops have been conducted for science and math teachers. These workshops where provided by the Department, both as part of general OBE training and as part of the MSSI project. The workshops generally last from two days to one week and are done in clusters or districts. While the workshops are seen by teachers to be very beneficial and well run, there is a feeling that more help is still needed with the implementation of C2005 and with some content areas.

While the notion of school-based professional development is acknowledged as being valuable, it is not clear how effective or sustainable it has become at this point. It is possible that if it were not monitored, it would quietly be set aside.

The professional development provided by the Department will need to focus on problem areas experienced by teachers.

\section{Direct support to learners}

Not much support is given to learners. Extra lessons have been provided by the teachers own their own initiative. For example the mathematics teacher for grade 9 provides extra lessons if she feels the lesson is not well understood by some of the learners.

Government subsidised lunches are not provided by the school.

In summary, the learners received no tangible outside support.

\section{Change forces, Accountability and Monitoring}

Changes that have taken place at the school are basically in response to outside, top-down directives about the implementation of C2005. While there is general satisfaction about the overall directions of these changes, there is some disquiet about the pace and lack of support. The teachers say they need total retraining to be able to implement C2005 effectively. More than that, C2005 was introduced very fast and there was no time for preparation in schools physically, socially, economically and professionally (human resources). If it was not for the top-down directives, it is unlikely that any changes would have occurred. Nevertheless, when asked whether they would continue with the implementation, most, but not all, teachers said that they would. In other words, although the impetus for change came from the outside, these changes have found broad support within the school. The next step will be for the school, as a community of learners, to take charge of their own destiny and begin to initiate further changes from within, rather than these being driven from the outside. 
School monitoring by the Department has not been done for two years. At a less formal level, $\mathrm{CI}^{\prime} \mathrm{s}$ have visited the school twice and it was after the workshops. These visits were a follow up to the INSET provided by CIs to find out if there were any problems with the implementation of C2005 in the school. If there were any problems faced by the teachers, the CIs were willing to try to help with finding a solution.

It would appear that the monitoring of progress in the implementation of C2005 is weak and sporadic, both internally and externally. There seems to be a great desire by staff at the school to know "how they are doing". As researchers, we encountered no obstacles to our presence in the classrooms and school in general. To the contrary, we were welcomed - unlike the experience of colleagues in other schools. We were surprised by the answers received when we asked whether the department should revert to the system of having school inspections. The reply was that if they came to help, and not spy, they would be welcome. Hence we have designed this report to try and give feedback to the school and to make recommendations as requested.

The ideal situation would be for the school itself to take more and more responsibility for the monitoring of its own progress, and to chart its own course in deciding how to improve. Ultimately the quality, pace and extent of the implementation should become the concern of the professional community of the school rather than that of outsiders.

Table 10.2

Summary of Constructs. School B

\begin{tabular}{|l|l|}
\hline \multicolumn{1}{|c|}{ Profile of Implementation - Classroom Interaction } \\
\hline Level 1 & $\begin{array}{l}\text { Classroom practice has certainly changed. One obvious difference is that on entering } \\
\text { any classroom, one sees that tables and chairs are arranged in groups and not rows } \\
\text { facing the teacher. Significant changes in teaching practices have also occurred. For } \\
\text { example, in both maths classes, learners were encouraged to work through the given } \\
\text { problems in groups, and in so doing help one another. } \\
\text { Nevertheless, these new teaching styles are being used, for the most part, to achieve } \\
\text { the same goals as before. There is very little evidence that the specific outcomes of } \\
\text { either mathematics or science are being addressed. }\end{array}$ \\
\hline \multicolumn{1}{|c|}{ Profile of Implementation - Science Practical Work } \\
\hline Level 2 & $\begin{array}{l}\text { In the science classes in grade } 8 \text { and 9, the teachers tried to use classroom } \\
\text { demonstrations to help the learners develop concepts. Attempts are being made to } \\
\text { make science more hands-on, making use of every-day equipment such as measuring } \\
\text { tapes, combs, balloons and electric plugs. } \\
\text { In both classes grade 8 and 9 learners performed guided discovery type practical } \\
\text { activities and group work was done. Students where given photocopied sheets from a } \\
\text { book, which showed them how to perform the activities and had questions to answer. }\end{array}$ \\
\hline Level 0.5 Profile of Implementation - Science/mathematics in Society \\
\hline $\begin{array}{l}\text { The Specific Outcomes that deal } \\
\text { with the interface of maths/science } \\
\text { and society are largely absent from } \\
\text { the lessons. Nevertheless, the grade } \\
\text { 9 science teacher feels that making } \\
\text { the link to everyday life is relatively } \\
\text { easy in science. }\end{array}$ \\
\hline
\end{tabular}




\begin{tabular}{|c|c|}
\hline \multicolumn{2}{|r|}{ Profile of Implementation - Assessment } \\
\hline Level 2/3 & $\begin{array}{l}\text { The science/maths subject policy calls for two tests per quarter. It does not specifiy } \\
\text { any other kind of assessment. Written tests were used as one of the methods to assess } \\
\text { the students. Most questions did not require recall, but needed application of } \\
\text { knowledge gained in the study. Some questions needed higher order thinking. } \\
\text { Despite the lack of mention of other assessment strategies in the policy document, all } \\
\text { the teachers used other sources besides the tests to assess the progress of their } \\
\text { learners. These include projects (e.g. the creation of a chart), class-work, homework, } \\
\text { written reports and oral presentations. } \\
\text { No learner portfolios where seen in science and mathematics. }\end{array}$ \\
\hline \multicolumn{2}{|r|}{ Profile of Capacity - Resources } \\
\hline Level 1 & $\begin{array}{l}\text { The school has no library although } \\
\text { there are plans to convert one } \\
\text { classroom into a library. There is no } \\
\text { laboratory, although again there are } \\
\text { plans to improve one, and very little } \\
\text { science equipment. There are no } \\
\text { computers. There is a copier } \\
\text { machine situated in the principal's } \\
\text { office. } \\
\text { The principal's office and classrooms all have electricity. Outside lights have been put } \\
\text { on the buildings recently. } \\
\text { Class rooms have enough desks for learners but the furniture needs to be upgraded } \\
\text { as a lot of the desks and chairs are broken. The class rooms are small and therefore } \\
\text { overcrowded. }\end{array}$ \\
\hline \multicolumn{2}{|r|}{ Profile of Capacity - Teacher factors } \\
\hline Level 2 & $\begin{array}{l}\text { The teachers are all qualified to teach maths and science, being in possession of STDs } \\
\text { or UDEs. One is studying for a degree at the moment, and others intend to study } \\
\text { further at some future date. } \\
\text { Teacher morale at the school is } \\
\text { good. However, the threat of } \\
\text { redeployment is discouraging. } \\
\text { Teachers co-operate well with one } \\
\text { another and are hard-working. } \\
\text { There is a good team spirit amongst } \\
\text { teachers at the school. } \\
\text { They try to do their work by applying different teaching methods, use improvised } \\
\text { resources in teaching, and provide extra classes to their learners. Conversations with } \\
\text { them, both formal and informal, are often peppered with phrases that convey their } \\
\text { concern and care for the learners at the school. Interactions between teachers and } \\
\text { learners are relaxed and respectful }\end{array}$ \\
\hline \multicolumn{2}{|r|}{ Profile of Capacity - Learner factors } \\
\hline Level 2 & $\begin{array}{l}\text { In general the learners are well behaved, under control, hard working and motivated. } \\
\text { Language proficiency among the learners is poor to reasonable. It is not possible to } \\
\text { teach in English alone. } \\
\text { Learners attend school on a regular basis and absenteeism is not a major problem. } \\
\text { The average attendance probably runs at about } 90 \% \text {. }\end{array}$ \\
\hline \multicolumn{2}{|r|}{ Profile of Capacity - School Ecology/Management } \\
\hline Level 2/3 & $\begin{array}{l}\text { The ethos of the school, and the way in which it is managed, is supportive of the } \\
\text { kinds of innovations envisaged by C2005. What exists at present could provide a } \\
\text { solid platform on which to continue to build and improve }\end{array}$ \\
\hline
\end{tabular}




\begin{tabular}{|c|c|}
\hline \multicolumn{2}{|r|}{ Profile of Outside Support - Professional Development } \\
\hline Level 1/2 & $\begin{array}{l}\text { Workshops have been conducted for science and math teachers. These workshops } \\
\text { where provided by the Department, both as part of general OBE training and as part } \\
\text { of the MSSI project. The workshops generally last from two days to one week and are } \\
\text { done in clusters or districts. }\end{array}$ \\
\hline \multicolumn{2}{|r|}{ Profile of Outside Support - Support to Learners } \\
\hline Level 0 & $\begin{array}{l}\text { Not much support is given to learners. Extra lessons have been provided by the } \\
\text { teachers own their own initiative. For example the mathematics teacher for grade } 9 \\
\text { provides extra lessons if she feels the lesson is not well understood by some of the } \\
\text { learners. } \\
\text { Government subsidised lunches are not provided by the school. In summary, the } \\
\text { learners received no tangible outside support. }\end{array}$ \\
\hline \multicolumn{2}{|r|}{ Profile of Outside Support - Provision of Resources } \\
\hline Level 1/2 & $\begin{array}{l}\text { The Department has been active in the past year in terms of the provision of physical } \\
\text { resources. The school has been provided with barbed-wire fencing, water and } \\
\text { electricity by the department. Not only that, but new rooms have been built and this } \\
\text { is also a support from the department. New textbooks have been received, but only } \\
\text { for grade } 9 \text { and not for all learning areas. These books are insufficient for every } \\
\text { student. The school is in need of science kits, chemicals, apparatuses and furniture for } \\
\text { the laboratory and the library. Other materials, like stationary, are also needed. }\end{array}$ \\
\hline \multicolumn{2}{|r|}{ Dominant change force } \\
\hline Level 1 & $\begin{array}{l}\text { Changes that have taken place at the school are basically in response to outside, top- } \\
\text { down directives about the implementation of C } 2005 \text {. While there is general } \\
\text { satisfaction about the overall directions of these changes, there is some disquiet about } \\
\text { the pace and lack of support. }\end{array}$ \\
\hline \multicolumn{2}{|r|}{ Monitoring mechanisms and accountability } \\
\hline Level 2 & $\begin{array}{l}\text { School monitoring by the Department has not been done for two years. At a less } \\
\text { formal level, CI's have visited the school twice and it was after the workshops. } \\
\text { It would appear that the monitoring of progress in the implementation of C } 2005 \text { is } \\
\text { weak and sporadic, both internally and externally. There seems to be a great desire by } \\
\text { staff at the school to know "how they are doing". }\end{array}$ \\
\hline
\end{tabular}




\section{APPENDIX 7}


Case study results for the sub-constructs of the Profile of Implementation

\begin{tabular}{|l|c|c|c|c|c|c|c|c|c|c|}
\hline \multicolumn{1}{|c|}{ School } & A & B & C & D & E & F & G & I & J & K \\
\hline Classroom interaction & 1.0 & 1.0 & 1.0 & 1.0 & 0.5 & 1.0 & 2.0 & 1.0 & 0.0 & 2.5 \\
\hline Science practical work & 0.0 & 2.0 & 0.0 & 0.5 & 0.0 & 1.0 & 2.5 & 0.0 & 0.0 & 1.5 \\
\hline Science in Society & 1.0 & 0.5 & 0.0 & 0.0 & 0.0 & 0.0 & 0.0 & 1.0 & 0.0 & 1.0 \\
\hline Assessment & 1.0 & 2.5 & 1.5 & 1.0 & 1.0 & 1.0 & 2.0 & 1.0 & 2.0 & 2.0 \\
\hline
\end{tabular}

Case study results for the construct of Capacity to Innovate

\begin{tabular}{|l|c|c|c|c|c|c|c|c|c|c|}
\hline \multicolumn{1}{|c|}{ School } & A & B & C & D & E & F & G & I & J & K \\
\hline Physical resources & 1.0 & 1.0 & 2.5 & 2.5 & 2.0 & 3.0 & 2.5 & 2.0 & 1.0 & 3.5 \\
\hline Teacher factors & 2.0 & 2.0 & 2.0 & 2.0 & 2.0 & 2.0 & 2.5 & 2.0 & 3.0 & 3.0 \\
\hline Learner factors & 1.5 & 2.0 & 2.5 & 2.0 & 1.0 & 2.0 & 2.0 & 0.0 & 2.0 & 3.0 \\
\hline $\begin{array}{l}\text { School } \\
\text { ethos/management }\end{array}$ & 3.0 & 2.5 & 2.0 & 2.0 & 2.0 & 2.0 & 3.0 & 2.0 & 1.0 & 3.0 \\
\hline
\end{tabular}

Case Study results the sub-construct Outside Support

\begin{tabular}{|l|c|c|c|c|c|c|c|c|c|c|}
\hline \multicolumn{1}{|c|}{ School } & A & B & C & D & E & F & G & I & J & K \\
\hline Provision of resources & 1.5 & 1.5 & 1.0 & 1.0 & 2.0 & 2.0 & 2.5 & 2.0 & 0.0 & 1.0 \\
\hline $\begin{array}{l}\text { Teacher professional } \\
\text { development }\end{array}$ & 0.0 & 0.0 & 0.0 & 0.0 & 1.0 & 1.0 & 2.5 & 0.0 & 0.0 & 0.0 \\
\hline Direct support to learners & 1.0 & 1.5 & 1.0 & 1.0 & 1.0 & 1.0 & 3.0 & 0.0 & 1.0 & 1.0 \\
\hline Change forces & 1.5 & 1.0 & 1.0 & 1.0 & 1.0 & 1.0 & 1.5 & 1.0 & 1.0 & 1.0 \\
\hline $\begin{array}{l}\text { Accountability and } \\
\text { monitoring }\end{array}$ & 3.0 & 2.0 & 2.0 & 0.5 & 1.0 & 1.0 & 3.0 & 1.0 & 0.0 & 4.0 \\
\hline
\end{tabular}


